PHOTOBIOLOGICAL HYDROGEN PRODUCTION FROM SUGAR BEET MOLASSES

A THESIS SUBMITTED TO

THE GRADUATE SCHOOL OF NATURAL AND APPLIED SCIENCES $\mathrm{OF}$ MIDDLE EAST TECHNICAL UNIVERSITY

BY

EMRAH SAĞIR

IN PARTIAL FULFILLMENT OF THE REQUIREMENTS

FOR

THE DEGREE OF MASTER OF SCIENCE

IN

BIOCHEMISTRY

FEBRUARY 2012 
Approval of the Thesis;

\section{PHOTOBIOLOGICAL HYDROGEN PRODUCTION FROM SUGAR BEET MOLASSES}

submitted by EMRAH SAĞIR in partial fulfillment of the requirements for the degree of Master of Science in Biochemistry Department, Middle East Technical University by,

Prof. Dr. Canan ÖZGEN

Dean, Graduate School of Natural and Applied Sciences

Prof. Dr. Candan GÜRAKAN

Head of the Department, Biochemistry

Prof. Dr. Meral YÜCEL

Supervisor, Biology Dept., METU

Dr. Ebru ÖZGÜR

Co-Supervisor, METU-MEMS

\section{Examining Committee Members:}

Prof. Dr. Orhan ADALI

Biology Dept., METU

Prof. Dr. Meral YÜCEL

Biology Dept., METU

Assoc. Prof. Dr. Füsun EYIDOĞAN

Elementary Education Dept., Başkent University

Dr. Yavuz ÖZTÜRK

TÜBITTAK-MAM

Dr. Ebru ÖZGÜR

METU-MEMS 
I hereby declare that all information in this document has been obtained and presented in accordance with academic rules and ethical conduct. I also declare that, as required by these rules and conduct, I have fully cited and referenced all material and results that are not original to this work.

Name, Last name : Emrah Sağır

Signature : 


\section{ABSTRACT \\ PHOTOBIOLOGICAL HYDROGEN PRODUCTION FROM SUGAR BEET MOLASSES}

Sağır, Emrah

M.Sc., Department of Biochemistry

Supervisor: Prof. Dr. Meral Yücel

Co-Supervisor: Dr. Ebru Özgür

February 2012, 169 pages

The main aim of this study was to investigate biological hydrogen production from sucrose and molasses by purple non-sulphur bacteria (PNS). The hydrogen production capacities of four different PNS bacteria (Rhodobacter capsulatus (DSM 1710), Rhodobacter capsulatus YO3 (Hup'), Rhodopseudomonas palustris (DSM 127) and Rhodobacter sphaeroides O.U.001 (DSM 5864)) were tested on sucrose and molasses. The photobiological hydrogen production were performed in $50 \mathrm{ml}$ and $150 \mathrm{ml}$ small scale photobioreactors, in batch mode. The produced hydrogen 
quantities, bacterial growth profiles and $\mathrm{pH}$ of the media were recorded through the photobiological hydrogen production processes. Organic acids and sucrose consumption rates were determined by HPLC during the experiments. The maximum hydrogen productivitiy of $0.78\left(\mathrm{mmol} / \mathrm{l}_{\mathrm{c}} \cdot \mathrm{h}\right)$ and $0.55\left(\mathrm{mmol} / \mathrm{l}_{\mathrm{c}} \cdot \mathrm{h}\right)$ was obtained by $R$. palustris (DSM 127) on sucrose and molasses, respectively. Secondly, co-cultivation of these bacterial strains was studied. The maximum hydrogen productivity by cocultivation of $R$. sphaeroides O.U.001 (DSM 5864) and R. palustris (DSM 127) was found as $1.0\left(\mathrm{mmol} / \mathrm{l}_{\mathrm{c}} \cdot \mathrm{h}\right)$.

Keywords: Biological Hydrogen Production, Purple Non-Sulphur Bacteria, Sucrose, Molasses, Photobioreactor 


\title{
ÖZ
}

\section{ŞEKER PANCARI MELASINDAN FOTOBIYYOLOJIK HIDDOJEN ÜRETIMMI}

\author{
Sağır, Emrah \\ Yüksek Lisans, Biyokimya Bölümü \\ Tez Yöneticisi : Prof. Dr. Meral Yücel \\ Ortak Tez Yöneticisi : Dr. Ebru Özgür
}

Şubat 2012, 169 sayfa

Bu çalışmanın asıl amacı mor kükürtsüz bakteriler tarafından sükroz ve melastan biyolojik hidrojen üretimini araştırılmasıdır. Dört farklı mor kükürtsüz bakteri’nin (Rhodobacter capsulatus (DSM 1710), Rhodobacter capsulatus YO3 (Hup'), Rhodopseudomonas palustris (DSM 127) ve Rhodobacter sphaeroides O.U.001 (DSM 5864)) sükroz ve melas üzerine hidrojen üretim kapasiteleri test edilmiştir. Fotobiyolojik hidrojen üretimleri 50 ve 150 ml'lik küçük ölçekli fotobiyoreaktörlerde gerçekleştirilmiştir. Fotobiyolojik hidrojen üretimi sürecinde üretilen hidrojen miktarı, büyüme profilleri ve ortamın $\mathrm{pH}^{\prime} 1$ kaydedilmiştir. Deneyler süresince organik asitler ve sükroz tüketim oranları kromatografi (HPLC) ile belirlenmiştir. Maksimum hidrojen üretim hızı $R$. palustris (DSM 127) tarafından sükroz ve melastan sırası ile $0.78\left(\mathrm{mmol} / \mathrm{l}_{\mathrm{c}} \cdot \mathrm{h}\right)$ and $0.55\left(\mathrm{mmol} / \mathrm{l}_{\mathrm{c}} . \mathrm{h}\right)$ olarak elde edilmiştir. İkinci olarak bu bakterilerin birlikte kültürleri çalışılmıştır. Maksimum hidrojen üretim hızı 
R. sphaeroides O.U.001 (DSM 5864) and R. palustris (DSM 127)' in birlikte oluşturduğu kültür tarafindan $1.0\left(\mathrm{mmol} / \mathrm{l}_{\mathrm{c}} \cdot \mathrm{h}\right)$ olarak bulunmuştur.

Anahtar Kelimeler: Biyolojik Hidrojen Üretimi, Mor Kükürtsüz Bakteriler, Sükroz, Melas, Fotobiyoreaktör 
To Memory of My Mother, 


\section{ACKNOWLEDGEMENTS}

I would like to thank sincerely to my supervisor Prof. Dr. Meral Yücel and my cosupervisor Dr. Ebru Özgür for their guidance, support and suggestions throughout this study.

I would like to give my special thanks to Prof. Dr. İnci Eroğlu and Prof. Dr. Ufuk Gündüz for their valuable ideas, aids and support. I also thank to Dr. Başar Uyar for his advices and ideas in this study.

I am grateful for all my labmates, Begüm Peksel, Dominic Deo Androga, Endam Özkan, Gökçe Avcıoğlu, Görkem Baysal, Kamal Elkahlaut, Muazzez Gürgan and Pelin Sevinç for their support and friendship.

I also thank Dr. Songül Gürel who is general manager of the Institute of Ankara Sugar Factory for her help with the supply of molasses.

I gratefully thank Dr. Tamay Şeker in METU Central Laboratory Molecular Biology and Biotechnology Research and Development Center for her help with HPLC analyses.

I greatly thank Gülten Orakçı for her help with GC and HPLC analyses in Chemical Engineering Department.

I would like to thank deeply Tuğçe Atasoy for her endless concern and support.

Lastly, I sincerely thank all members of my family, especially my parents for their help, support and love in all my life.

This study was supported by EU $6^{\text {th }}$ framework project "Hyvolution", ÖYP and BAP projects (07.02.2011-003). 


\section{TABLE OF CONTENTS}

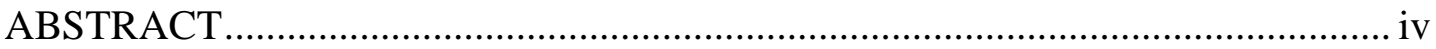

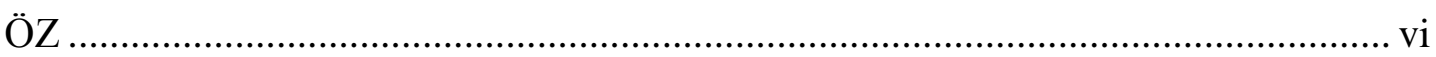

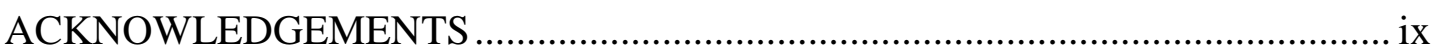

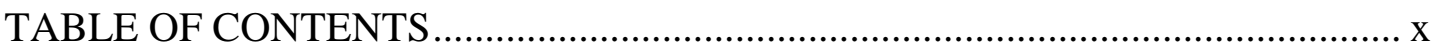

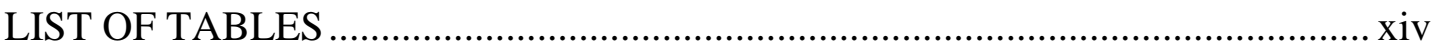

LIST OF FIGURES ….............................................................................

LIST OF SYMBOLS AND ABBREVIATIONS ............................................. xxix

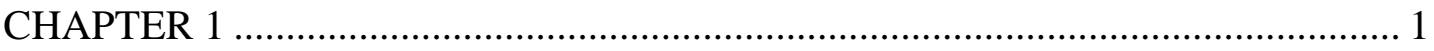

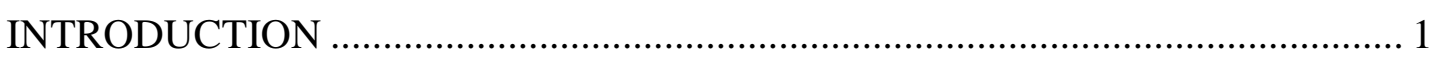

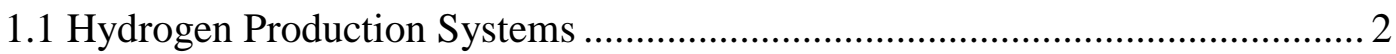

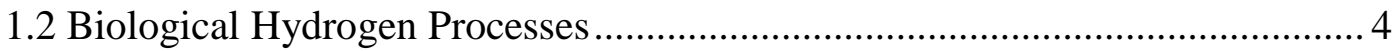

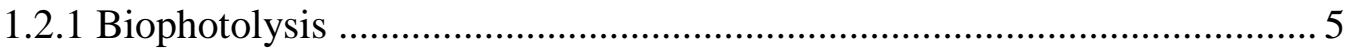

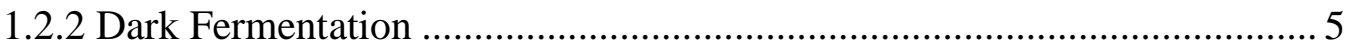

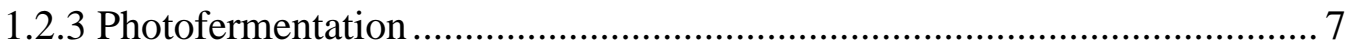

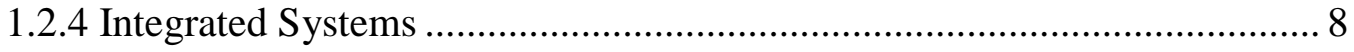

1.3 General Characteristics of Purple Non-sulphur Bacteria ................................ 9

1.4 Hydrogen Production Metabolism of PNS Bacteria ….................................. 12

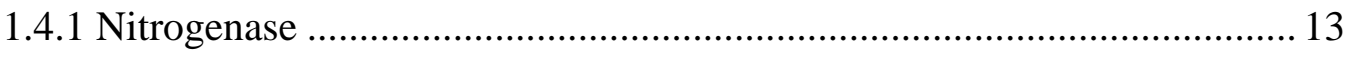

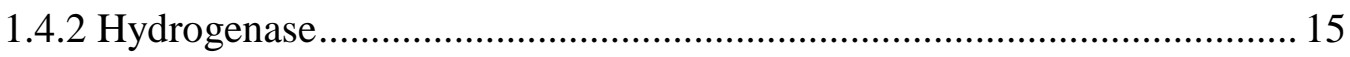


1.4.3 By-Products of Biological Hydrogen Production 16

1.5 Molasses as a Feedstock for Hydrogen Production........................................ 17

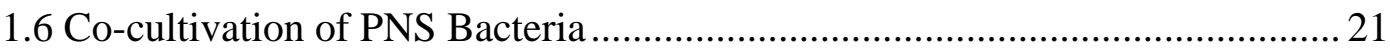

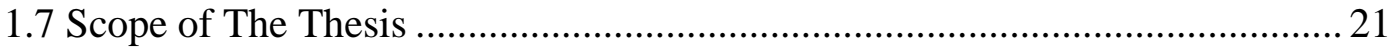

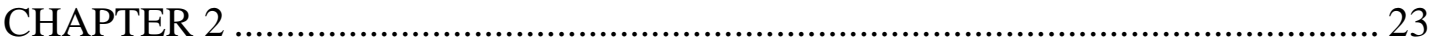

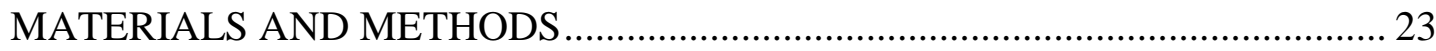

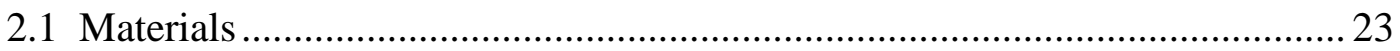

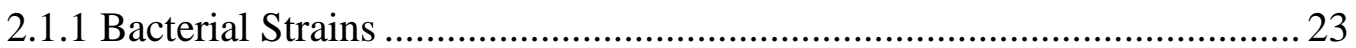

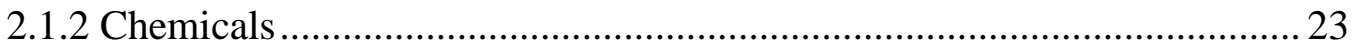

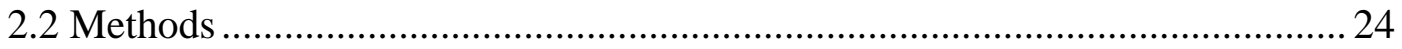

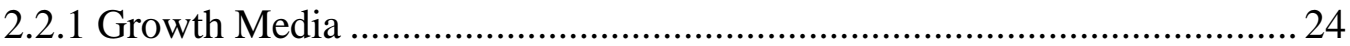

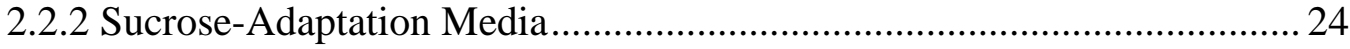

2.2.3 Hydrogen Production Media ............................................................. 25

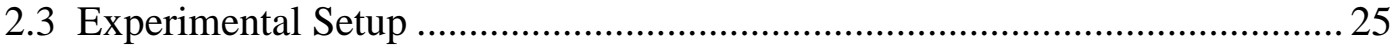

2.4 Hydrogen Production Procedure …............................................................. 27

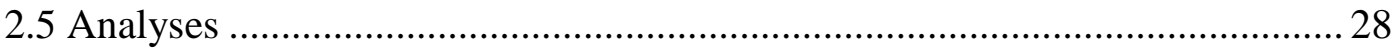

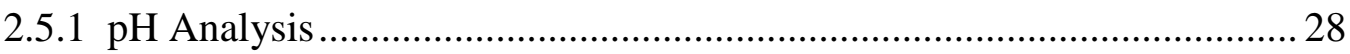

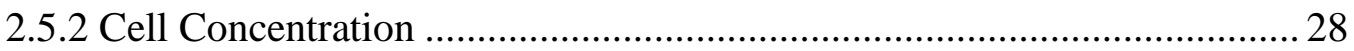

2.5.3 Analysis of Sugar and Organic Acids ................................................ 28

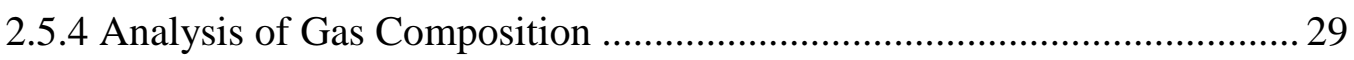

2.5.5 Molasses Composition and Pretreatment of Molassses .......................... 30

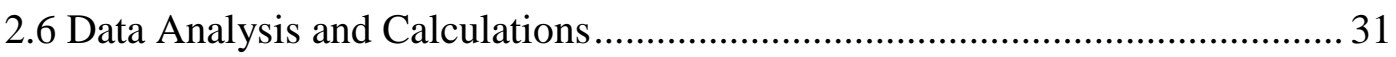

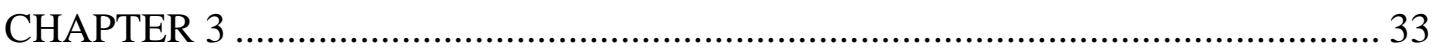

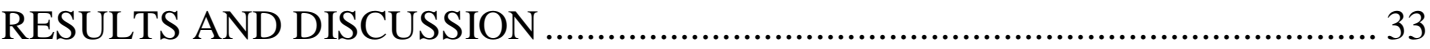


3.1.1 Adaptation of PNS Bacteria to Sucrose as Carbon Source 34

3.1.2 The Effect of Sucrose on Growth 34

3.1.2 The Effect of Buffer Concentrations 38

3.2 Growth and Hydrogen Production on Sucrose by Different Strains of Purple Non-sulfur (PNS) Bacteria 41

3.2.1 Experiments on $R$. capsulatus (DSM 1710). .42

3.2.2 Experiments on $R$. capsulatus YO3 (Hup) 47

3.2.3 Experiments on R. palustris (DSM 127). 51

3.2.4 Experiments on R. sphaeroides O.U.001 (DSM 5864). 54

3.3 Growth and Hydrogen Production on Molasses by Different Strains of Purple Non-sulfur (PNS) Bacteria 57

3.3.1 Experiments on $R$. capsulatus (DSM 1710). .57

3.3.2 Experiments on $R$. capsulatus YO3 (Hup') 61

3.3.3 Experiments on R. palustris (DSM 127) 66

3.3.4 Experiments on $R$. sphaeroides O.U.001 (DSM 5864). 69

3.4 Comparison of the Experiments .73

3.5 Co-cultivation of PNS Bacteria 80

3.6.2 Co-cultivation of $R$. capsulatus YO3 (Hup') and R. palustris (DSM 127)81 3.6.3 Co-cultivation of $R$. palustris (DSM 127) and $R$. sphaeroides O.U.001 (DSM 5864) .85

3.6.2 Co-cultivation of $R$. capsulatus YO3 (Hup ${ }^{-}$) and $R$. sphaeroides O.U.001 (DSM 5864) .88

3.6.4 Mixed-cultures of $R$. capsulatus YO3 (Hup), R. palustris (DSM 127) and $R$. sphaeroides O.U.001 (DSM 5864). 92 98 


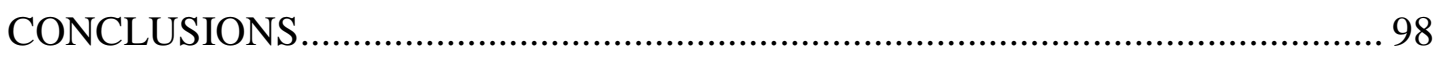

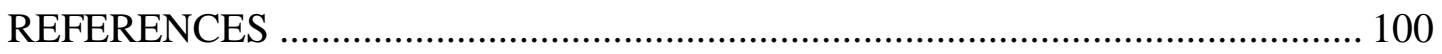

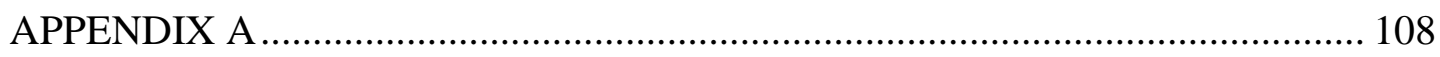

COMPOSITION OF THE MEDIA AND SOLUTIONS …................................. 108

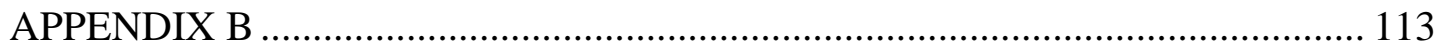

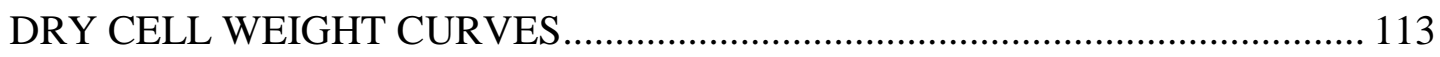

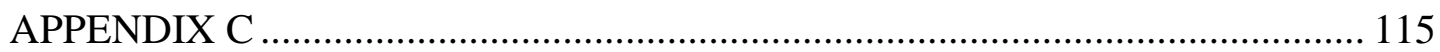

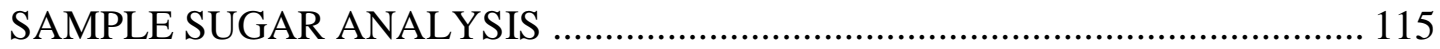

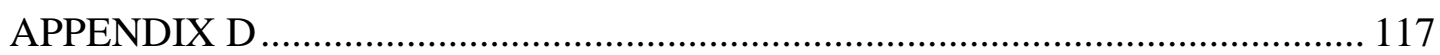

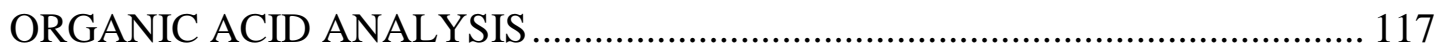

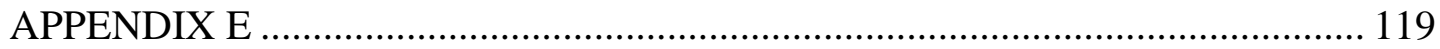

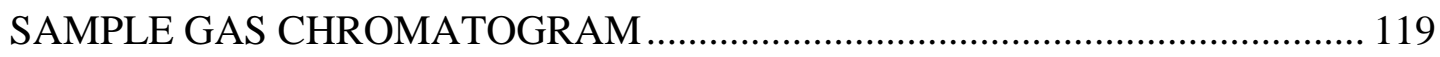

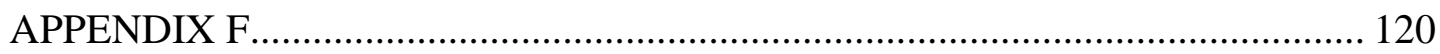

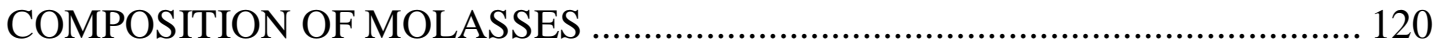

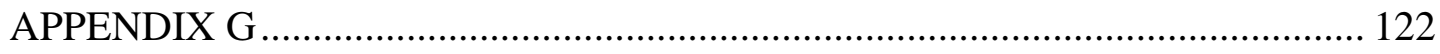

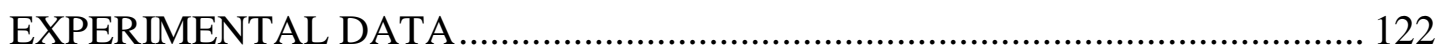

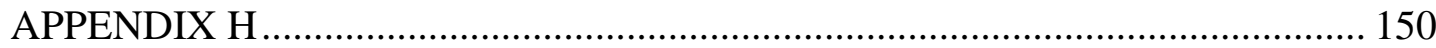




\section{LIST OF TABLES}

\section{TABLES}

Table 1.1 Classification of hydrogen-generative bacteria...................................... 11

Table 1.2 The classification of the PNS bacteria used in this study........................ 11

Table 2.1 The growth media of PNS bacteria for activation (1), and adaptation of bacteria to sucrose, (2) and (3)

Table 2.2 Dilutions carried out on molasses feedstock to obtain desired sucrose concentrations.

Table 2.3 The composition of undiluted molasses used in the experiments

Table 3.1 Concentrations of organic acids in photofermentation of R.capsulatus DSM 1710 on $5 \mathrm{mM}, 7.5 \mathrm{mM}$ and $10 \mathrm{mM}$ sucrose hydrogen production media. ..... 44

Table 3.2 The utilization of sucrose by R.capsulatus (DSM 1710) on $5 \mathrm{mM}, 7.5 \mathrm{mM}$ and $10 \mathrm{mM}$ sucrose hydrogen production media.

Table 3.3 Concentrations of organic acids in photofermentation of R.capsulatus YO3 (Hup ${ }^{-}$) on $5 \mathrm{mM}, 7.5 \mathrm{mM}$ and $10 \mathrm{mM}$ sucrose hydrogen production media. Glutamate $(2 \mathrm{mM})$ was used as the nitrogen source. 50

Table 3.4 The utilization of sucrose by R.capsulatus YO3 (Hup ${ }^{-}$) on $5 \mathrm{mM}, 7.5 \mathrm{mM}$ and $10 \mathrm{mM}$ sucrose hydrogen production media.

Table 3.5 Concentrations of organic acids in photofermentation of $R$. palustris (DSM127) on $5 \mathrm{mM}, 7.5 \mathrm{mM}$ and $10 \mathrm{mM}$ sucrose hydrogen production media. ..... 53

Table 3.6 The utilization of sucrose by $R$. palustris (DSM127) on $5 \mathrm{mM}, 7.5 \mathrm{mM}$ and $10 \mathrm{mM}$ sucrose hydrogen production media.

Table 3.7 Concentrations of organic acids in photofermentation of $R$. sphaeroides O.U.001 (DSM 5864) on $5 \mathrm{mM}, 7.5 \mathrm{mM}$ and $10 \mathrm{mM}$ sucrose hydrogen production media. .56

Table 3.8 The utilization of sucrose by $R$. sphaeroides O.U.001 (DSM 5864) on 5 $\mathrm{mM}, 7.5 \mathrm{mM}$ and $10 \mathrm{mM}$ sucrose hydrogen production media. 
Table 3.9 Concentrations of organic acids in photofermentation of $R$. capsulatus (DSM 1710) on $5 \mathrm{mM}, 7.5 \mathrm{mM}$ and $10 \mathrm{mM}$ sucrose (molasses) hydrogen production media.

Table 3.10 The utilization of sucrose by $R$. capsulatus (DSM 1710) on $5 \mathrm{mM}, 7.5$ $\mathrm{mM}$ and $10 \mathrm{mM}$ sucrose (molasses) hydrogen production media.

Table 3.11 Concentrations of organic acids in photofermentation of R.capsulatus YO3 (Hup) on $5 \mathrm{mM}, 7.5 \mathrm{mM}$ and $10 \mathrm{mM}$ sucrose (molasses) hydrogen production media.

Table 3.12 The utilization of sucrose by R.capsulatus YO3 (Hup ${ }^{-}$) on $5 \mathrm{mM}, 7.5 \mathrm{mM}$ and $10 \mathrm{mM}$ sucrose (molasses) hydrogen production media.

Table 3.13 Concentrations of organic acids in photofermentation of $R$. palustris (DSM 127) on $5 \mathrm{mM}, 7.5 \mathrm{mM}$ and $10 \mathrm{mM}$ sucrose (molasses) hydrogen production media.

Table 3.14 The utilization of sucrose by $R$. palustris (DSM 127) on $5 \mathrm{mM}, 7.5 \mathrm{mM}$ and $10 \mathrm{mM}$ sucrose (molasses) hydrogen production media.

Table 3.15 Concentrations of organic acids in photofermentation of $R$. sphaeroides O.U.001 (DSM 5864) on $5 \mathrm{mM}, 7.5 \mathrm{mM}$ and $10 \mathrm{mM}$ sucrose (molasses) hydrogen production media.

Table 3.16 The utilization of sucrose by $R$. palustris (DSM 127) on $5 \mathrm{mM}, 7.5 \mathrm{mM}$ and $10 \mathrm{mM}$ sucrose (molasses) hydrogen production media.

Table 3.17 Duration of the processes and total hydrogen production of different PNS bacteria on defined sucrose media in $50 \mathrm{ml}$ bioreactors. .74

Table 3.18 Summary of the results with different PNS bacteria on defined sucrose media in $50 \mathrm{ml}$ bioreactors.

Table 3.19 Duration of the processes and total hydrogen production of different PNS bacteria on molasses in $50 \mathrm{ml}$ bioreactors.

Table 3.20 Summary of the results with different PNS bacteria on molasses in $50 \mathrm{ml}$ bioreactors. .78

Table 3.19 Co-cultured bacterial strains. 80

Table 3.20 The concentrations of the organic acids in co-cultivation of $R$. capsulatus YO3 (Hup') and R. palustris (DSM 127). 
Table 3.21 The sucrose consumption (\%) during growth and hydrogen production by single cell and co-culturesof $R$. capsulatus YO3 (Hup-) and $R$. palustris (DSM 127 ) on molasses medium with $5 \mathrm{mM}$ sucrose.

Table 3.22 The concentrations of the organic acids in co-cultivation of $R$. palustris (DSM 127) and R. sphaeroides O.U.001 (DSM 5864).

Table 3.23 The sucrose consumption (\%) in co-cultivation of $R$. palustris (DSM 127) and $R$. sphaeroides O.U.001 (DSM 5864).

Table 3.24 The concentrations of the organic acids in co-cultivation of $R$. capsulatus YO3 (Hup') and R. sphaeroides O.U.001 (DSM 5864).

Table 3.21 The sucrose consumption (\%) in co-cultivation of $R$. capsulatus YO3 (Hup ${ }^{-}$) and R. sphaeroides O.U.001 (DSM 5864).

Table 3.25 The concentrations of the organic acids in multiple-cultivation of $R$. capsulatus YO3 (Hup'), R. palustris (DSM 127) and R. sphaeroides O.U.001 (DSM 5864).

Table 3.26 The sucrose consumption (\%) in multiple-cultivation of $R$. capsulatus YO3 (Hup ), R. palustris (DSM 127) and R. sphaeroides O.U.001 (DSM 5864).... 94

Table 3.23 Duration of the processes and total hydrogen production of different PNS bacteria in $150 \mathrm{ml}$ bioreactors.

Table 3.24 Summary of the co-cultivation of different PNS bacteria on $5 \mathrm{mM}$ sucrose from molasses.

Table A.1 Composition of the growth medium 108

Table A.2 Composition of sucrose-acetate growth medium (20 mM Sucrose/10 mM Acetate) 109

Table A.3 Composition of sucrose-acetate growth medium (10 mM Sucrose) ....... 110

Table A.4 Hydrogen production media with different sucrose $\left(5^{*}, 7.5^{* *}, 10^{* * *} \mathrm{mM}\right)$ concentrations

A 5. Composition of trace elements solution (1X) components.

Table G1 OD, pH, dry cell weight and hydrogen production of $5 \mathrm{mM}$ sucrose containing molasses medium by $R$. capsulatus DSM 1710 ....... 
Table G2 Organic acid concentrations $(\mathrm{mM})$ in $5 \mathrm{mM}$ sucrose medium by $R$. capsulatus DSM 1710.

Table G3 OD, pH, dry cell weight and hydrogen production of $7.5 \mathrm{mM}$ sucrose defined medium by $R$. capsulatus DSM 1710

Table G4 Organic acid concentrations $(\mathrm{mM})$ in $7.5 \mathrm{mM}$ sucrose medium by $R$. capsulatus DSM 1710.

Table G5 OD, pH, dry cell weight and hydrogen production of $10 \mathrm{mM}$ sucrose defined medium by $R$. capsulatus DSM 1710

Table G6 Organic acid concentrations $(\mathrm{mM})$ in $10 \mathrm{mM}$ sucrose medium by $R$. capsulatus DSM 1710.

Table G7 OD, pH, dry cell weight and hydrogen production of $5 \mathrm{mM}$ sucrose defined medium by R. capsulatus YO3.

Table G8 Organic acid concentrations $(\mathrm{mM})$ in $5 \mathrm{mM}$ sucrose medium by $\mathrm{R}$. capsulatus YO3

Table G9 OD, pH, dry cell weight and hydrogen production of $7.5 \mathrm{mM}$ sucrose defined medium by R. capsulatus YO3. 126

Table G10 Organic acid concentrations (mM) in $7.5 \mathrm{mM}$ sucrose medium by $R$. capsulatus YO3

Table G11 OD, pH, dry cell weight and hydrogen production of $10 \mathrm{mM}$ sucrose defined medium by $R$. capsulatus YO3 127

Table G12 Organic acid concentrations (mM) in $10 \mathrm{mM}$ sucrose medium by $R$. capsulatus YO3

Table G13 OD, $\mathrm{pH}$, dry cell weight and hydrogen production of $5 \mathrm{mM}$ sucrose defined medium by $R$. palustris (DSM 127) 128

Table G14 Organic acid concentrations $(\mathrm{mM})$ in $5 \mathrm{mM}$ sucrose medium by $R$. palustris (DSM 127) 128

Table G15 OD, pH, dry cell weight and hydrogen production of $7.5 \mathrm{mM}$ sucrose defined medium by $R$. palustris (DSM 1710)

Table G16 Organic acid concentrations (mM) in $7.5 \mathrm{mM}$ sucrose medium by $R$. palustris (DSM 127) 129 
Table G17 OD, pH, dry cell weight and hydrogen production of $10 \mathrm{mM}$ sucrose defined medium by $R$. palustris (DSM 127)

Table G18 Organic acid concentrations $(\mathrm{mM})$ in $10 \mathrm{mM}$ sucrose medium by $R$. palustris (DSM 127)

Table G19 OD, pH, dry cell weight and hydrogen production of $5 \mathrm{mM}$ sucrose containing molasses medium by $R$. sphaeroides O.U.001

Table G21 OD, pH, dry cell weight and hydrogen production of $7.5 \mathrm{mM}$ sucrose containing molasses medium by $R$. sphaeroides O.U.001

Table G22 Organic acid concentrations $(\mathrm{mM})$ in $7.5 \mathrm{mM}$ sucrose medium by $R$. sphaeroides O.U.001

Table G23 OD, pH, dry cell weight and hydrogen production of $10 \mathrm{mM}$ sucrose containing molasses medium by $R$. sphaeroides O.U.001

Table G24 Organic acid concentrations in $10 \mathrm{mM}$ sucrose medium by $R$. sphaeroides O.U.001

Table G25 OD, pH, dry cell weight and hydrogen production of $5 \mathrm{mM}$ sucrose containing molasses medium by R. capsulatus DSM 1710

Table G26 Organic acid concentrations (mM) in $5 \mathrm{mM}$ molasses (sucrose) medium by $R$. capsulatus DSM 1710 .

Table G27 OD, pH, dry cell weight and hydrogen production of $7.5 \mathrm{mM}$ sucrose containing molasses medium by $R$. capsulatus DSM 1710

Table G28 Organic acid concentrations (mM) in $7.5 \mathrm{mM}$ molasses (sucrose) medium by $R$. capsulatus DSM 1710 .

Table G29 OD, pH, dry cell weight and hydrogen production of $10 \mathrm{mM}$ sucrose containing molasses medium by $R$. capsulatus DSM 1710 136

Table G30 Organic acid concentrations (mM) in $10 \mathrm{mM}$ molasses (sucrose) medium by $R$. capsulatus DSM 1710. 136

Table G31 OD, pH, dry cell weight and hydrogen production of $5 \mathrm{mM}$ molasses (sucrose) medium by $R$. capsulatus YO3

Table G32 Organic acid concentrations in $5 \mathrm{mM}$ molasses (sucrose) medium by $R$. capsulatus YO3 
Table G33 OD, pH, dry cell weight and hydrogen production of $7.5 \mathrm{mM}$ molasses (sucrose) medium by $R$. capsulatus YO3

Table G34 Organic acid concentrations (mM) in $7.5 \mathrm{mM}$ molasses (sucrose) medium by $R$. capsulatus YO3 138

Table G35 OD, pH, dry cell weight and hydrogen production of $10 \mathrm{mM}$ molasses (sucrose) medium by $R$. capsulatus YO3

Table G36 Organic acid concentrations (mM) in $10 \mathrm{mM}$ molasses (sucrose) medium by $R$. capsulatus YO3

Table G37 OD, pH, dry cell weight and hydrogen production of $5 \mathrm{mM}$ molasses (sucrose) medium by $R$. palustris (DSM 127) .....

Table G38 Organic acid concentrations (mM) in $5 \mathrm{mM}$ molasses (sucrose) medium by $R$. palustris (DSM 127).

Table G39 OD, pH, dry cell weight and hydrogen production of $7.5 \mathrm{mM}$ molasses (sucrose) medium by $R$. palustris (DSM 127)

Table G40 Organic acid concentrations (mM) in $7.5 \mathrm{mM}$ molasses (sucrose) medium by $R$. palustris (DSM 127)....

Table G41 OD, $\mathrm{pH}$, dry cell weight and hydrogen production of $10 \mathrm{mM}$ molasses (sucrose) medium by $R$. palustris (DSM 127).

Table G42 Organic acid concentrations (mM) in $10 \mathrm{mM}$ molasses (sucrose) medium by $R$. palustris (DSM 127).

Table G43 OD, pH, dry cell weight and hydrogen production of $5 \mathrm{mM}$ sucrose containing molasses medium by $R$. sphaeroides O.U.001

Table G44 Organic acid concentrations (mM) in $5 \mathrm{mM}$ molasses (sucrose) medium by $R$. sphaeroides O.U.001

Table G45 OD, pH, dry cell weight and hydrogen production of $7.5 \mathrm{mM}$ sucrose containing molasses medium by $R$. sphaeroides O.U.001

Table G46 Organic acid concentrations (mM) in $7.5 \mathrm{mM}$ molasses (sucrose) medium by $R$. sphaeroides O.U.001

Table G47 OD, pH, dry cell weight and hydrogen production of $7.5 \mathrm{mM}$ sucrose containing molasses medium by $R$. sphaeroides O.U.001 
Table G48 Organic acid concentrations (mM) in $10 \mathrm{mM}$ molasses (sucrose) medium by $R$. sphaeroides O.U.001

G49-G53 Experimental data for co-cultivation studies in $150 \mathrm{ml}$ bioreactors.

Table G49 OD, pH, dry cell weight and hydrogen production of $5 \mathrm{mM}$ molasses sucrose medium by $R$. palustris (DSM 127) 146

Table G50 OD, pH, dry cell weight and hydrogen production of $5 \mathrm{mM}$ molasses sucrose medium by $R$. capsulatus YO3 (Hup-)

Table G51 OD, pH, dry cell weight and hydrogen production on $5 \mathrm{mM}$ molasses sucrose medium by the co-cultivation of $R$. palustris (DSM 127) and $R$. capsulatus YO3 (Hup-)

Table G52 OD, pH, dry cell weight and hydrogen production of $5 \mathrm{mM}$ molasses sucrose medium by $R$. sphaeroides O.U.001

Table G53 OD, pH, dry cell weight and hydrogen production of $5 \mathrm{mM}$ molasses sucrose medium by $R$. palustris (DSM 127) 148

Table G53 OD, pH, dry cell weight and hydrogen production of the co-cultivation of $R$. sphaeroides O.U.001 and R. palustris (DSM 127) on $5 \mathrm{mM}$ molasses sucrose medium 149 


\section{LIST OF FIGURES}

\section{FIGURES}

Figure 1.1 Dark fermentative hydrogen production............................................. 6

Figure 1.2 The microscopic images of PNS bacteria ............................................ 10

Figure 1.3 A sketch of the carbon metabolism in PNS bacteria ............................. 13

Figure 1.4 Photofermentation by PNS bacteria.................................................... 14

Figure 1.5 Hydrogen production metabolism of PNS bacteria............................... 16

Figure 2.1 Schematic illustration of experimental setup....................................... 26

Figure 2.2 The picture of experimental setup for hydrogen production. .................. 27

Figure 3.1 The growth of $R$. capsulatus (DSM1710) on sucrose (20 mM), acetate (30 $\mathrm{mM})$ and a mixture of sucrose-acetate $(20 \mathrm{mM} / 10 \mathrm{mM})$ defined media.................. 35

Figure 3.2 The growth of R.capsulatus YO3 (Hup-) on sucrose (20 mM), acetate (30 $\mathrm{mM})$ and a mixture of sucrose-acetate $(20 \mathrm{mM} / 10 \mathrm{mM})$ defined media. Glutamate (2 $\mathrm{mM}$ ) was the nitrogen source for all the bacteria................................................... 35

Figure 3.3 The cumulative hydrogen production of $R$. capsulatus (DSM 1710) on sucrose $(20 \mathrm{mM})$, acetate $(30 \mathrm{mM})$ and a mixture of sucrose-acetate $(20 \mathrm{mM} / 10 \mathrm{mM})$ defined media. Glutamate $(2 \mathrm{mM})$ was the nitrogen source for all the bacteria........ 36

Figure 3.4 The cumulative hydrogen production of R.capsulatus YO3 (Hup-) on sucrose $(20 \mathrm{mM})$, acetate $(30 \mathrm{mM})$ and a mixture of sucrose-acetate $(20 \mathrm{mM} / 10 \mathrm{mM})$ defined media. Glutamate $(2 \mathrm{mM})$ was the nitrogen source for all the bacteria.

Figure 3.5 The changes of $\mathrm{pH}$ on $20 \mathrm{mM}$ sucrose media by R.capsulatus DSM 1710 and R.capsulatus YO3 (Hup-).

Figure $3.6 \mathrm{pH}$ curves of R.capsulatus YO3 (Hup-) in $5 \mathrm{mM}$ sucrose defined medium (DF) which is prepared by different concentrations of $\mathrm{KH}_{2} \mathrm{PO}_{4}$ buffers (initial $\mathrm{pH}$ was 7.0) 38

Figure $3.7 \mathrm{pH}$ curves of R.capsulatus YO3 (Hup-) in $5 \mathrm{mM}$ sucrose from molasses which is prepared by different concentrations of $\mathrm{KH}_{2} \mathrm{PO}_{4}$ buffers (initial $\mathrm{pH}$ was 7.0) 
Figure $3.8 \mathrm{pH}$ curves of R.capsulatus YO3 (Hup-) in $5 \mathrm{mM}$ sucrose defined medium which is prepared by different concentrations of $\mathrm{KH}_{2} \mathrm{PO}_{4}$ buffers (initial $\mathrm{pH}$ was 7.5)

Figure $3.9 \mathrm{pH}$ curves of R.capsulatus YO3 (Hup-) in $5 \mathrm{mM}$ sucrose from molasses which was prepared by different concentrations of $\mathrm{KH}_{2} \mathrm{PO}_{4}$ buffers (initial $\mathrm{pH}$ was 7.5)

Figure 3.10 The cumulative hydrogen production $(\mathrm{ml})$ at different concentrations of $\mathrm{KH}_{2} \mathrm{PO}_{4}$ buffers on $5 \mathrm{mM}$ sucrose from molasses in $50 \mathrm{ml} \mathrm{PBRs}$

Figure 3.11 The growth of $R$. capsulatus DSM 1710 on $5 \mathrm{mM}, 7.5 \mathrm{mM}$ and $10 \mathrm{mM}$ sucrose hydrogen production media.

Figure 3.12 The $\mathrm{pH}$ changes of $R$. capsulatus DSM 1710 on $5 \mathrm{mM}, 7.5 \mathrm{mM}$ and 10 $\mathrm{mM}$ sucrose hydrogen production media

Figure 3.13 The cumulative hydrogen production of $R$. capsulatus DSM 1710 on 5 $\mathrm{mM}, 7.5 \mathrm{mM}$ and $10 \mathrm{mM}$ sucrose hydrogen production media.

Figure 3.14 Organic acid production by $R$. capsulatus (DSM 1710) on $5 \mathrm{mM}$ sucrose defined medium

Figure 3.15 Formic acid production by $R$. capsulatus DSM 1710 on different sucrose concentrations.

Figure 3.16 Sucrose consumption by $R$. capsulatus DSM 1710 on $5 \mathrm{mM}, 7.5 \mathrm{mM}$ and $10 \mathrm{mM}$ sucrose hydrogen production media.

Figure 3.17 The growth of $R$. capsulatus YO3 (Hup-) on $5 \mathrm{mM}, 7.5 \mathrm{mM}$ and $10 \mathrm{mM}$ sucrose hydrogen production media.

Figure 3.18 The mode of $\mathrm{pH}$ of $R$. capsulatus YO3 (Hup-) on $5 \mathrm{mM}, 7.5 \mathrm{mM}$ and 10 $\mathrm{mM}$ sucrose hydrogen production media.

Figure 3.19 The cumulative hydrogen production (1/lc) of $R$. capsulatus YO3 (Hup-) on $5 \mathrm{mM}, 7.5 \mathrm{mM}$ and $10 \mathrm{mM}$ sucrose hydrogen production media.

Figure 3.20 Acetic acid and formic acid production on $5 \mathrm{mM}$ sucrose by $R$. capsulatus YO3 (Hup ${ }^{-}$).

Figure 3.21 The consumption curves of $R$. capsulatus YO3 (Hup-) on different sucrose concentrations. 50 
Figure 3.15 The growth of $R$. palustris (DSM 127) on $5 \mathrm{mM}, 7.5 \mathrm{mM}$ and $10 \mathrm{mM}$ sucrose hydrogen production media.

Figure 3.16 The $\mathrm{pH}$ changes of $R$. palustris (DSM127) on $5 \mathrm{mM}, 7.5 \mathrm{mM}$ and 10 $\mathrm{mM}$ sucrose hydrogen production media.

Figure 3.17 The cumulative hydrogen production of $R$. palustris (DSM127) on 5 $\mathrm{mM}, 7.5 \mathrm{mM}$ and $10 \mathrm{mM}$ sucrose hydrogen production media............................... 53

Figure 3.18 The growth of $R$. sphaeroides O.U.001 (DSM 5864) on $5 \mathrm{mM}, 7.5 \mathrm{mM}$ and $10 \mathrm{mM}$ sucrose containing hydrogen production media.

Figure 3.19 The pH changes of $R$. sphaeroides O.U.001 (DSM 5864) on $5 \mathrm{mM}, 7.5$ $\mathrm{mM}$ and $10 \mathrm{mM}$ containing sucrose hydrogen production media. .55

Figure 3.20 The cumulative hydrogen production of $R$. sphaeroides O.U.001 (DSM 5864) on $5 \mathrm{mM}, 7.5 \mathrm{mM}$ and $10 \mathrm{mM}$ sucrose containing hydrogen production media.

Figure 3.21 The growth of $R$. capsulatus (DSM 1710) in different sucrose concentrations $(5,7.5$ and $10 \mathrm{mM})$ by dilutions of molasses. .58

Figure $3.22 \mathrm{pH}$ variation during hydrogen production by $R$. capsulatus (DSM 1710) on different molasses media with different sucrose concentrations $(5,7.5$ and 10 $\mathrm{mM})$.

Figure 3.23 The cumulative hydrogen production by $R$. capsulatus (DSM 1710) on molasses media with different sucrose concentrations $(5,7.5$ and $10 \mathrm{mM})$.

Nearly half of the sucrose in molasses was utilized for growth and hydrogen production. The initial and final sucrose concentrations in PBRs were given in Table 3.10. Figure 3.24 is given for organic acid concentrations by $R$. capsulatus (DSM 1710) on molasses medium containing $5 \mathrm{mM}$ sucrose.

Figure 3.24 Organic acid concentrations of $R$. capsulatus (DSM 1710) on molasses medium containing $5 \mathrm{mM}$ sucrose.

Figure 3.25 The growth of $R$. capsulatus YO3 (Hup-) in different sucrose concentrations $(5,7.5$ and $10 \mathrm{mM})$ by dilutions of molasses.

Figure 3.26 The $\mathrm{pH}$ variation during hydrogen production by $R$. capsulatus YO3 (Hup ${ }^{-}$) on molasses with different sucrose concentrations (5, 7.5 and $\left.10 \mathrm{mM}\right)$... 63 
Figure 3.27 Figure 3.27 The cumulative hydrogen production by $R$. capsulatus YO3 (Hup-) on molasses with different sucrose concentrations (5, 7.5 and $10 \mathrm{mM})$.

Figure 3.28 Acetic, lactic and propionic acid concentraitons during hydrogen production by $R$. capsulatus YO3 (Hup-) on molasses medium with $5 \mathrm{mM}$ sucrose. 65

Figure 3.29 The consumption of sucrose by R. capsulatus YO3 (Hup ${ }^{-}$). 65

Figure 3.30 The growth of $R$. palustris (DSM 127) on molasses media with different sucrose concentrations $(5,7.5$ and $10 \mathrm{mM})$. 66

Figure 3.31 The variation in $\mathrm{pH}$ during hydrogen production by $R$. palustris (DSM 127) on molasses media with different sucrose concentrations (5, 7.5 and $10 \mathrm{mM}) .67$

Figure 3.32 The cumulative hydrogen production of $R$. palustris (DSM 127) on molasses media with different sucrose concentrations $(5,7.5$ and $10 \mathrm{mM})$. 68

Figure 3.33 The growth of $R$. sphaeroides O.U.001 (DSM 5864) on molasses media with different sucrose concentrations $(5,7.5$ and $10 \mathrm{mM})$.

Figure 3.34 The variation in $\mathrm{pH}$ during hydrogen production by $R$. sphaeroides O.U.001 (DSM 5864) on molasses media with different sucrose concentrations (5, 7.5 and $10 \mathrm{mM})$ 71

Figure 3.35 The cumulative hydrogen production by $R$. sphaeroides O.U.001 (DSM $5864)$ on molasses media with different sucrose concentrations $(5,7.5$ and $10 \mathrm{mM})$.

Figure 3.36 The substrate conversion efficiencies of different PNS bacteria on various sucrose concentrations in $50 \mathrm{ml}$ bioreactors. 75

Figure 3.37 The hydrogen productivities of different PNS bacteria on various sucrose concentrations in $50 \mathrm{ml}$ bioreactors.

Figure 3.38 The substrate conversion efficiencies of different PNS bacteria on molasses with different sucrose concentrations (5-7.5-10 mM). 79

Figure 3.39 The hydrogen productivities of different PNS bacteria on molasses with different sucrose concentrations (5-7.5-10 mM).

Figure 3.40 The $\mathrm{pH}$ variation in single cell and co-cultures of $R$. capsulatus YO3 (Hup-) and $R$. palustris (DSM 127), during hydrogen production on molasses medium with $5 \mathrm{mM}$ sucrose. 
Figure 3.41 The growth of single cell and co-cultures of $R$. capsulatus YO3 (Hup-) and $R$. palustris (DSM 127) on molasses medium with $5 \mathrm{mM}$ sucrose.

Figure 3.42 The cumulative hydrogen production of single cell and co-cultures of $R$. capsulatus YO3 (Hup ${ }^{-}$) and $R$. palustris (DSM 127) on molasses medium with $5 \mathrm{mM}$ sucrose.

Figure 3.43 The $\mathrm{pH}$ variation in single cell and co-cultures of $R$. sphaeroides O.U.001 (DSM 5864) and R. palustris (DSM 127), during hydrogen production on molasses medium with $5 \mathrm{mM}$ sucrose.

Figure 3.44 The growth of single cell and co-cultures of $R$. sphaeroides O.U.001 (DSM 5864) and $R$. palustris (DSM 127) on molasses medium with $5 \mathrm{mM}$ sucrose.

Figure 3.45 The cumulative hydrogen production of single cell and co-cultures of $R$. sphaeroides O.U.001 (DSM 5864) and R. palustris (DSM 127) on molasses medium with $5 \mathrm{mM}$ sucrose.

Figure 3.46 The $\mathrm{pH}$ variation in single cell and co-cultures of $R$. capsulatus YO3 (Hup-) and R. sphaeroides O.U.001 (DSM 5864) on molasses medium with $5 \mathrm{mM}$ sucrose.

Figure 3.47 The growth of single cell and co-cultures of $R$. capsulatus YO3 (Hup-) and $R$. sphaeroides O.U.001 (DSM 5864) on molasses medium with $5 \mathrm{mM}$ sucrose.

Figure 3.48 The cumulative hydrogen production of single cell and co-cultures of $R$. capsulatus YO3 (Hup-) and R. sphaeroides O.U.001 (DSM 5864) on molasses medium with $5 \mathrm{mM}$ sucrose.

Figure 3.49 The changes of $\mathrm{pH}$ in mixed-cultures of $R$. capsulatus YO3 (Hup-), $R$. palustris (DSM 127) and $R$. sphaeroides O.U.001 (DSM 5864) on molasses medium with $5 \mathrm{mM}$ sucrose.

Figure 3.50 The cumulative hydrogen production and growth curves in mixed-culture of $R$. capsulatus YO3 (Hup-), R. palustris (DSM 127) and R. sphaeroides O.U.001 (DSM 5864).

Figure B1. Calibration curve of $R$. capsulatus YO3.

Figure B2. Calibration curve of $R$. capsulatus (DSM 1710)

Figure B3. Calibration curve of $R$. palustris (DSM 127). 
Figure C1. Sample sugar HPLC chromatogram

Figure C.2 Sample standard sucrose calibration curve ......................................... 116

Figure D1. Sample HPLC organic acid chromatogram ....................................... 117

Figure D.1 Calibration curve of sample acetic acid............................................ 118

Figure E. Sample gas chromatogram …........................................................... 119

Table F. Composition of Undiluted Molasses..................................................... 120

Figure H1 Concentrations of organic acids in photofermentation of R.capsulatus DSM 1710 on $5 \mathrm{mM}$ sucrose hydrogen production media. 150

Figure $\mathrm{H} 2$ Concentrations of organic acids in photofermentation of R.capsulatus DSM 1710 on $7.5 \mathrm{mM}$ sucrose hydrogen production media.

Figure H3 Concentrations of organic acids in photofermentation of R.capsulatus DSM 1710 on $10 \mathrm{mM}$ sucrose hydrogen production media. 151

Figure H4 Concentrations of organic acids in photofermentation of R.capsulatus YO3 (Hup ${ }^{-}$) on $5 \mathrm{mM}$ sucrose hydrogen production media. 152

Figure H5 Concentrations of organic acids in photofermentation of R.capsulatus YO3 (Hup ${ }^{-}$) on $7.5 \mathrm{mM}$ sucrose hydrogen production media.

Figure H6 Concentrations of organic acids in photofermentation of R.capsulatus YO3 (Hup-) on $10 \mathrm{mM}$ sucrose hydrogen production media. 153

Figure $\mathrm{H} 7$ Concentrations of organic acids in photofermentation of $R$. palustris (DSM 127) on $5 \mathrm{mM}$ sucrose hydrogen production media. 153

Figure $\mathrm{H} 8$ Concentrations of organic acids in photofermentation of $R$. palustris (DSM 127) on $7.5 \mathrm{mM}$ sucrose hydrogen production media. 154

Figure H9 Concentrations of organic acids in photofermentation of $R$. palustris (DSM 127) on $10 \mathrm{mM}$ sucrose hydrogen production media.. 154

Figure H10 Concentrations of organic acids in photofermentation of $R$. sphaeroides O.U.001 on $5 \mathrm{mM}$ sucrose hydrogen production media. 155

Figure H11 Concentrations of organic acids in photofermentation of $R$. sphaeroides O.U.001 on $7.5 \mathrm{mM}$ sucrose hydrogen production media. 155 
Figure H12 Concentrations of organic acids in photofermentation of $R$. sphaeroides O.U.001 on $10 \mathrm{mM}$ sucrose hydrogen production media.

Figure H13 Concentrations of organic acids in photofermentation of $R$. capsulatus DSM 1710 on molasses medium with $5 \mathrm{mM}$ sucrose hydrogen production media. 156

Figure H14 Concentrations of organic acids in photofermentation of $R$. capsulatus DSM 1710 on molasses medium with $7.5 \mathrm{mM}$ sucrose hydrogen production media.

Figure H15 Concentrations of organic acids in photofermentation of $R$. capsulatus (DSM 1710) on molasses medium with $10 \mathrm{mM}$ sucrose hydrogen production media.

Figure H16 Concentrations of organic acids in photofermentation of $R$. capsulatus YO3 (Hup-) on molasses medium with $5 \mathrm{mM}$ sucrose hydrogen production media. 158

Figure H17 Concentrations of organic acids in photofermentation of $R$. capsulatus YO3 (Hup-) on molasses medium with $7.5 \mathrm{mM}$ sucrose hydrogen production media. 158

Figure H18 Concentrations of organic acids in photofermentation of $R$. capsulatus YO3 (Hup-) on molasses medium with $10 \mathrm{mM}$ sucrose hydrogen production media.

Figure H19 Concentrations of organic acids in photofermentation of $R$. palustris (DSM 127) on molasses medium with $5 \mathrm{mM}$ sucrose hydrogen production media.159

Figure $\mathrm{H} 20$ Concentrations of organic acids in photofermentation of $R$. palustris (DSM 127) on molasses medium with $7.5 \mathrm{mM}$ sucrose hydrogen production media.

Figure $\mathrm{H} 21$ Concentrations of organic acids in photofermentation of $R$. palustris (DSM 127) on molasses medium with $10 \mathrm{mM}$ sucrose hydrogen production media. 160

Figure H22 Concentrations of organic acids in photofermentation of $R$. sphaeroides O.U.001 on molasses medium with $5 \mathrm{mM}$ sucrose hydrogen production media. ... 161

Figure H23 Concentrations of organic acids in photofermentation of $R$. sphaeroides O.U.001 on molasses medium with $7.5 \mathrm{mM}$ sucrose hydrogen production media. 161 
Figure H24 Concentrations of organic acids in photofermentation of $R$. sphaeroides O.U.001 on molasses medium with $10 \mathrm{mM}$ sucrose hydrogen production media. . 162

Figure H25-H33. Concentrations of organic acids of co-cultivation studies of PNS bacteria in $150 \mathrm{ml}$ bioreactors.

Figure $\mathrm{H} 25$ Concentrations of organic acids in photofermentation of $R$. palustris (DSM 127) on molasses medium with $5 \mathrm{mM}$ sucrose hydrogen production media 163

Figure H26 Concentrations of organic acids in photofermentation of $R$. capsulatus YO3 (Hup-) on molasses medium with $5 \mathrm{mM}$ sucrose hydrogen production media. 163

Figure $\mathrm{H} 27$ Concentrations of organic acids in photofermentation of the cocultivation of $R$. palustris (DSM 127) and R. capsulatus YO3 (Hup-) on molasses medium with $5 \mathrm{mM}$ sucrose hydrogen production media. 164

Figure H28 Concentrations of organic acids in photofermentation of $R$. sphaeroides O.U.001 on molasses medium with $5 \mathrm{mM}$ sucrose hydrogen production media. ... 164

Figure H29 Concentrations of organic acids in photofermentation of $R$. palustris (DSM 127) on molasses medium with $5 \mathrm{mM}$ sucrose hydrogen production media.165

Figure H30 Concentrations of organic acids in photofermentation of the cocultivation of $R$. palustris (DSM 127) and $R$. sphaeroides on molasses medium with $5 \mathrm{mM}$ sucrose hydrogen production media. 165

Figure H31 Concentrations of organic acids in photofermentation of $R$. capsulatus YO3 (Hup-) on molasses medium with $5 \mathrm{mM}$ sucrose hydrogen production media. 166

Figure $\mathrm{H} 32$ Concentrations of organic acids in photofermentation of the cocultivation of $R$. capsulatus YO3 (Hup-) and $R$. sphaeroides on molasses medium with $5 \mathrm{mM}$ sucrose hydrogen production media. 166

Figure H33 Concentrations of organic acids in photofermentation of the cocultivation of $R$. palustris (DSM 127), R. capsulatus YO3 (Hup-) and $R$. sphaeroides on molasses medium with $5 \mathrm{mM}$ sucrose hydrogen production media. 167 


\section{LIST OF SYMBOLS AND ABBREVIATIONS}

\begin{tabular}{|c|c|}
\hline Acetyl-CoA & Acetyl Coenzyme A \\
\hline ADP & Adenosine di-Phosphate \\
\hline ATP & Adenosine tri-Phosphate \\
\hline $\mathrm{C}$ & Carbon \\
\hline $\mathrm{C}_{0}$ & Initial concentration \\
\hline $\mathrm{C}_{\mathrm{f}}$ & Final concentration \\
\hline COD & Chemical Oxygen Demand \\
\hline C. saccharolyticus & Caldicellulosiruptor saccharolyticus \\
\hline $\mathrm{Fd}$ & Ferredoxin \\
\hline GC & Gas Chromatography \\
\hline gdcw & Gram dry cell weight of bacteria \\
\hline $\mathrm{H}_{2}$ & Hydrogen \\
\hline $\mathrm{H}$ & Hours \\
\hline HPLC & High Pressure Liquid Chromatography \\
\hline hup $^{-}$ & Uptake Hydrogenase Deficient \\
\hline 1 & liter \\
\hline $1_{c}$ & liter-culture \\
\hline $\mathrm{mM}$ & Millimolar \\
\hline mmol & Millimole \\
\hline $\mathrm{N}$ & Nitrogen \\
\hline NAD & Nicotineamid Adenine Dinucleotide \\
\hline PBR & Photobioreactor \\
\hline PHB & Poly- $\beta$-hydroxy butyrate \\
\hline $\mathrm{p}_{\mathrm{i}}$ & Inorganic Phosphate \\
\hline PNS & Purple Non-Sulphur \\
\hline PFL & Pyruvate formate lyase \\
\hline PFOR & Pyruvate ferredoxin (flavodoxin) oxidoreductase \\
\hline TCA & Tricarboxylic acid \\
\hline
\end{tabular}


R. capsulatus

R. palustris

$R$. sphaeroides
Rhodobacter capsulatus

Rhodopseudomonas palustris

Rhodobacter sphaeroides 


\section{CHAPTER 1}

\section{INTRODUCTION}

Nowadays, the depletion of fossil fuels which have limited reserves is a huge problem of the world for energy requirement. As fossil fuels are coming to a shortage, alternative energy sources are searched for substitution of fossil fuels. Hydrogen is accepted as a new renewable energy carrier that can respond for our energy demand. Hydrogen is a clean and renewable fuel for the future energy production. It is the most abundant element in the earth, and has a high content of energy (142 kJ/g) when compared with other sources (Das and Veziroglu., 2001). Advances in hydrogen production avenue are expected by the aid of genetic studies, co-culture studies and reactor designs for immobilized cells to increase the hydrogen yield (McKinlay and Harwood., 2010).

A sustainable energy supply is important for the future populations of human in the world. Many attemps are being realized in the energy sector and studies in this area takes growing attentions in a rapid way. The priorities for alternative production methods are supposed to have a manner of economically low cost and sustainable in a long term hydrogen production. Biohydrogen production from renewable resources, like biomass is considered as one of the most promising systems for future energy requirement. General mechanisms of producing hydrogen and biological hydrogen production methods are given in chapter 1 . In the same chapter, photofermentation is explained. The metabolism and characteristics of the photofermentative bacteria is given in detail. The procedures, experimental materials and methods part are examined in chapter 2 . 
Experimental studies are given in chapter 3 in detail. In the same chapter the results of the experiments and discussions are available. The experimental results, figures, tables and drawings are also present in chapter 3.

Concluding remarks are explained in conclusion part in chapter 5. Then references, appendices and experimental data are available in the last part of the thesis.

\subsection{Hydrogen Production Systems}

Hydrogen can be produced in two main broads. The method of application depends on the type of source. New green technologies have interest for a long term sustainable hydrogen production by increasing the efficiency of systems. There are essentially two kinds of hydrogen production systems. It may be obtained from conventional or thermochemical processes and non-thermal or renewable sources. These processes are summarized below; (Kothari et al, 2008).

1. Hydrogen from thermochemical production methods

Hydrogen is produced by thermochemical processing of hydrocarbons such as coal , natural gas, wastes, or biomass (Ogden, 1999).

a) Steam Reforming of Methane : The most common method for producing hydrogen is steam reforming of methane. In this process, hydrogen is obtained in three steps; steam reforming, water-gas shift reaction and purification of hydrogen. The steps of the reactions are shown in Equation (1.1) and (1.2).

$$
\mathrm{CH}_{4}+\mathrm{H}_{2} \mathrm{O} \leftrightarrow \mathrm{CO}+3 \mathrm{H}_{2} \text { (steam reforming) }
$$




$$
\mathrm{CO}+\mathrm{H}_{2} \mathrm{O} \rightarrow \mathrm{CO}_{2}+\mathrm{H}_{2} \text { (water-gas shift reaction) }
$$

This method is widespread and hydrogen is produced by the reaction of steam with methane. Steam reforming of methane (natural gas) results in the production of carbon monoxide, which is a greenhouse gas, causes global warming (Pilavachi et al, 2009).

b) Partial Oxidation of Hydrocarbons

In partial oxidation of hydrocarbons, there is an exothermic reaction of the hydrocarbons with oxygen and steam at mid-pressure. Equation (1.3) indicates hydrogen production in partial oxidation of hydrocarbons.

$$
2 \mathrm{C}_{\mathrm{n}} \mathrm{H}_{\mathrm{m}}+\mathrm{H}_{2} \mathrm{O}+23 / 2 \mathrm{O}_{2} \rightarrow \mathrm{nCO}_{2}+\mathrm{nCO}_{2}+(\mathrm{m}+1) \mathrm{H}_{2}
$$

c) Hydrogen from Water : Splitting of water into hydrogen and oxygen via electrolysis is another common method which hydrogen is produced. Renewable sources may be utilized in this process but it necessitates high amount of electricity.

These conventional methods are fossil fuel dependent and not environmentally friend. They are highly energy intensive and cause greenhouse effect by producing various chemicals in nature.

2. Non-thermal hydrogen production methods

Hydrogen can be produced by nothermal methods such as solar power, wind power and hydrogen power.

a) Solar power: When the water emits energy $(285.57 \mathrm{~kJ} / \mathrm{mole})$ from UV radiation of the sun, molecular hydrogen is produced. Oxygen is also by-product of the reaction by the solar power. 
b) Wind power: Wind power can be used for electricity source in electrolysis to produce hydrogen. As a source, wind turbine generated electricity is the most clean way of producing hydrogen.

c) Hydropower: Hydropower is considered as a source for producing hydrogen via electrolysis. Splitting of water into oxygen and hydrogen is performed by using electricity produced from hydropower.

d) Biological hydrogen production: Biological hydrogen production is an opportunity as an alternative, less energy intensive method since renewable sources can be widely used as raw materials. The concept of biological hydrogen production comprises a broad range of microorganisms such as algae, cyanobacteria, anaerobic and photosynthetic bacteria (Uyar, 2008).

\subsection{Biological Hydrogen Processes}

Biological hydrogen production are carried out by the utilization of fermentative bacteria, photosynthetic bacteria, algae and cyanobacteria under special conditions (Nandi and Sengupta, 1998). The biological hydrogen production can be categorized as below; (Das and Veziroğlu, 2001).

a. Biophotolysis of water using algae and cyanobacteria.

b. Fermentative hydrogen production from organic compounds.

c. Photodecomposition of organic compounds by photosynthetic bacteria.

d. Hybrid systems using photosynthetic and fermentative bacteria. 


\subsubsection{Biophotolysis}

Biophotolysis is the photo-evolution of hydrogen and oxygen gases by the splitting of water in biological systems under light. Equation 1.4 shows the biophotolysis reaction. The biophotolysis is performed by algae and cyanobacteria at anaerobic conditions (Gaffron and Rubin, 1992).

$$
\mathrm{H}_{2} \mathrm{O}+\text { light } \rightarrow \mathrm{H}_{2}+{ }^{1} / 2 \mathrm{O}_{2}
$$

Although biophotolysis is a direct and clean energy method for hydrogen production, it seems that this method has some barriers and drawbacks. Hydrogen production efficiency is low and the produced oxygen affects and inhibits nitrogenase and hydrogenase enzymes which are directly involved in biophotolysis reaction ( $\mathrm{Yu}$ and Takahashi, 2007).

\subsubsection{Dark Fermentation}

Dark fermentative bacteria are able to oxidize organic substrates during the heterotrophic growth in the absence of light. Pyruvate, a product of the glycolysis pathway, is oxidized to acetyl-CoA. The formation of acetyl-CoA entails the reduction of ferredoxin $(\mathrm{Fd})$. Molecular hydrogen is produced by the action of hydrogenase enzyme by the oxidation of the reduced ferrodoxin (Hallenbeck and Benemann, 2002). Various organic acids can be produced during dark fermentation processes by degradation of biomass or other organic wastes such as sugars like glucose and sucrose.

1) Pyruvate:formate lyase (PFL)

Pyruvate $+\mathrm{CoA} \underset{\mathrm{PFL}}{\longrightarrow}$ acetyl $-\mathrm{CoA}+$ formate

2) Pyruvate:ferredoxin (flavodoxin) oxidoreductase (PFOR) 
Pyruvate $+\mathrm{CoA}+2 \mathrm{Fd}(\mathrm{ox}) \longrightarrow$ acetyl $-\mathrm{CoA}+\mathrm{CO}_{2}+2 \mathrm{Fd}($ red $)$

Pyruvate is broken down by one of the two enzymatic system which were shown in reactions in (1.5) and (1.6).

Major products of the dark fermentation are small molecular weight organic compounds such as acetic acid, butyric acid and propionic acid due to incomplete utilization of the substrates in the operation. One of the major drawback of this process is low hydrogen production rate. Sequential dark and photo-fermentation systems can be more efficient in biological hydrogen production than a sole dark fermentative process (Kapdan and Kargi, 2006).

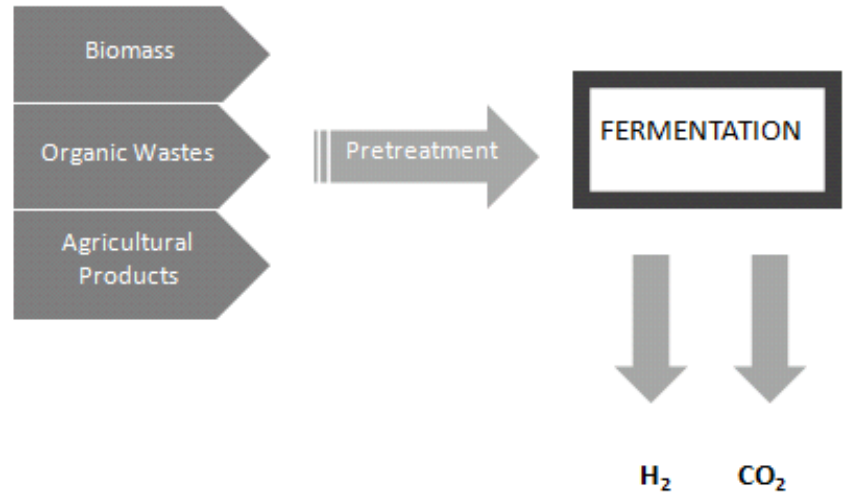

Figure 1.1 Dark fermentative hydrogen production adapted from Hallenbeck and Benemann, (2002). 


\subsubsection{Photofermentation}

Photosynthetic Purple non-sulfur (PNS) bacteria presents a remarkable photoheterotrophic hydrogen production mechanism with their nitrogenase enzyme by reducing organic substances under light energy.

Photobiological hydrogen production by PNS bacteria offers some important advantages over other processes by the aid of photosynthetic bacteria in the processes. Photoheterotrophic bacteria are accepted as the most favorable microorganisms for the biological hydrogen production (Akkerman et al., 2002; Fascetti and Todini, 1995; Miyake and Kawamura, 1987). The advantageous features of photoheterotrophic bacteria for hydrogen production are listed below (Das and Veziroğlu, 2001).

a) They have high conversion yields for hydrogen production,

b) They benefit from the wide range of light spectrum,

c) High consumption ability on different organic substrates or wastes, and

d) Give opportunities in biological waste treatment or prevent environmental pollution.

The major drawback of photoheterotrophic hydrogen production by PNS bacteria is their low production rates compared to dark fermentative process. Besides, major improvements in the bioreactor design are still necessary for the cost-effective photobiological hydrogen production.

This bacteria were also studied for hydrogen production from organic wastes (Eroglu et al., 2004) 
Uyar et al., (2009) studied photoproduction of hydrogen by Rhodobacter capsulatus and reported that this PNS bacteria is a good candidate for photofermentation and also for a combined dark and photofermentative process.

\subsubsection{Integrated Systems}

New hydrogen gas production systems may be developed to improve hydrogen yield. Sequential and combined dark and photo-fermentation processes are considered as a promising approach in terms of enhancing the hydrogen production. The effluent which comes from the dark fermentative operation, is aimed for utilization by photofermentative bacteria to produce more hydrogen (Kapdan and Kargi, 2006).

A current example to the integrated hydrogen production system is "HYVOLUTION", which is a EU $6^{\text {th }}$ Framework project, coordinated by Institute of Food and Biobased Research (DLO-FBR), The Netherlands. Hyvolution project intends to generate hydrogen from biomass by first dark fermentation (thermophilic) and then photofermentation processes. In thermophilic fermentation, biomass is utilized by thermophilic microorganisms. Hydrogen, carbondioxide and organic intermediates are produced in thermophilic process and these intermediate products are consumed in the second step by photofermentative bacteria and more hydrogen is produced by the integrated system. About nine moles of hydrogen per mole of hexose is aimed considering, 75\% efficiency (Claassen and Vrije, 2006).

Two step processes were also studied using sucrose obtained from different wastes. Tao et al. (2007) reported a two-step dark and photo-fermentation process. Hydrogen rate was raised from $3.67 \mathrm{~mol} \mathrm{H}_{2} / \mathrm{mol}$ sucrose in dark fermentation to $6.63 \mathrm{~mol}$ $\mathrm{H}_{2} /$ mol sucrose by $R$. sphaeroides with a two-step fermentation of sucrose. All of the organic acids produced in dark fermentation is consumed in the photofermentation part of two-step process. Özgür et al. (2010) studied on hydrogen production by sequential dark and photo-fermentation with sucrose from sugar beet molasses as 
carbon source. The maximum hydrogen is produced by $C$. saccharolyticus and $R$. capsulatus hup mutant strain in dark and photo-fermentation, respectively. They improved the yield of hydrogen from $4.2 \mathrm{~mol} \mathrm{H}_{2} / \mathrm{mol}$ sucrose in dark fermentation to $13.7 \mathrm{~mol} \mathrm{H}_{2} / \mathrm{mol}$ sucrose by the sequential process.

\subsection{General Characteristics of Purple Non-sulphur Bacteria}

Purple non-sulphur bacteria (PNS) are photosynthetic microorganisms which can grow at near $\mathrm{pH}$ 6-9 and a temperature range of $25-35{ }^{\circ} \mathrm{C}$ (Sasikala et al., 1993). They have ability to grow in various modes such as aerobically chemoautotrophic and chemoheterotrophic or anaerobically phototrophic and photoheterotropic (Koku., 2002).

Rhodobacter capsulatus is a gram-negative purple non-sulphur bacterium. It is a rodshaped photosynthetic microorganism with a cell diameter of 0.5-1.2 $\mu \mathrm{m}$. This bacteria has a photosynthetic membrane and cell division occurs by binary fission and (Imhoff et al., 1995). Shown in Figure 1.2 is a microscopic image of Rhodobacter capsulatus.

Rhodobacter sphaeroides is also a PNS bacterium and can be in various shapes but generally has an ovoid cell shape with a photosynthetic membrane and bacteriochlorophyll $a$. Their cells have a dimension of $0.5 \mu \mathrm{m}$ wide and 2-2.5 $\mu \mathrm{m}$ long (Pellerin and Gest, 1983).

Rhopseudomonas palustris is known as one of the most metabolically suitable organism for biological processes. They are gram-negative bacteria which belong to Bradyrhizobiaceae family and Rhodopseudomonas genus. $R$. palustris is a rodshaped phototropic bacterium which could reproduce by budding (Whittenbury and McLee., 1967). The photosynthetic reaction center of the Rhodopseudomonas bacteria has bacteriochlorophyll $b$ and have a range of different modes (Lang and Oesterhelt, 1989). 


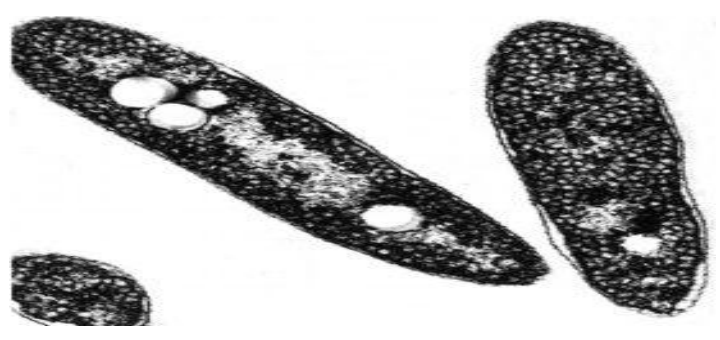

(a)

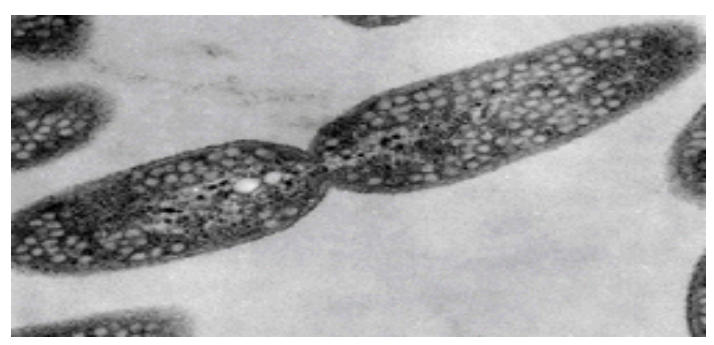

(b)
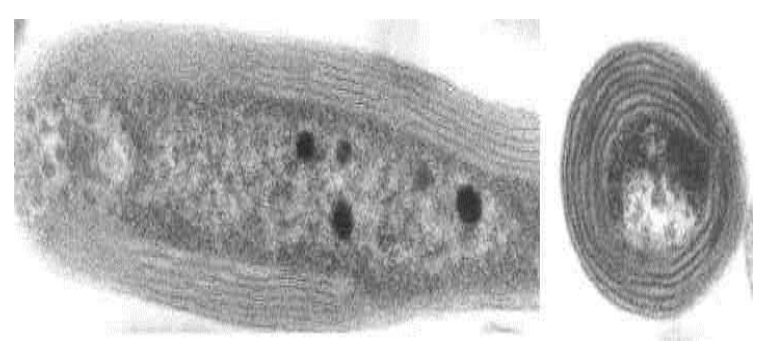

(c)

Figure 1.2 The microscopic images of PNS bacteria. $R$. capsulatus (a) (from Institut für Molekulare Enzymetechnologie), R. sphaeroides (b) (from Institute of Doe Joint Genome), and $R$. palustris (c) (from Dr. Gert-Wieland Kohring, University of Saarland, Germany. 
Table 1.1 Classification of hydrogen-generative bacteria (Basak and Das, 2007)

\begin{tabular}{|c|c|c|c|c|c|}
\hline Available energy form & Enzyme for $\mathrm{H} 2$ & Class of bacteria & Sub-class of bacteria & Genus of bacteria & Electron donor \\
\hline \multirow[t]{9}{*}{ Photosynthesis } & Hydrogenase & Green algae & - & Chlamydomonas & Water \\
\hline & & & & Chlorella & Water \\
\hline & & Cyano-bacteria & Heterocyst & Anabeana & Water \\
\hline & & & Non-heterocyst & Oscillataria & Water \\
\hline & Nitrogenase & Photo-synthetic & Purple-non-sulfur & Rhodobacter & Organic acids \\
\hline & & bacteria & (PNS) bacteria & Rhodopseudomonas & Organic acids \\
\hline & & & (Facultative anaerobe) & Rhodospirillum & Organic acids \\
\hline & & & Purple sulfur bacteria & Chromatium & Sulfates \\
\hline & & & & Thiocapsa & Sulfates \\
\hline \multirow[t]{7}{*}{ Non-photosynthesis } & Hydrogenase & Obligate anaerobe & - & Clostridium & Sugars \\
\hline & & Facultative anaerobe & - & Methanobacterium & Sugars \\
\hline & & & - & Escherichia & Sugars \\
\hline & & & - & Enterobacter & Sugars \\
\hline & Nitrogenase & Nitrogen fixing & Facultative aerobes & Azotobacter & Sugars \\
\hline & & bacteria & & Clostridium & Sugars \\
\hline & & & Facultative anaerobes & Klebsiella & Sugars \\
\hline
\end{tabular}

Table 1.2 The classification of the PNS bacteria used in this study (Tabanoğlu, 2002; Uyar, 2008).

\begin{tabular}{|l|l|l|l|}
\hline Domain & Bacteria & Bacteria & Bacteria \\
\hline Phylum & Proteobacteria & Proteobacteria & Proteobacteria \\
\hline Class & Alphaproteobacteria & Alphaproteobacteria & Alphaproteobacteria \\
\hline Order & Rhodobacterales & Rhodobacteraceae & Rhizobiales \\
\hline Family & Rhodobacteraceae & Rhodobacteraceae & Bradyrhizobiaceae \\
\hline Genus & Rhodobacter & Rhodobacter & Rhodopseudomonas \\
\hline Species & capsulatus & sphaeroides & palustris \\
\hline
\end{tabular}

R. palustris is commonly found in various places in nature such as water ponds and marine coasts. This bacteria are accepted as one of the most metabolically suitable 
microorganism. For gaining energy, they can utilize light, different organic substances or inorganics. Many alternative growth modes are available in $R$. palustris. They are able to grow in the absence or presence of oxygen and have degradative effect on many organic compounds (Larimer et al., 2003).

\subsection{Hydrogen Production Metabolism of PNS Bacteria}

Hydrogen evolution is carried out by utilization of organic substrates under an illumination in an anaerobic medium. The hydrogen production metabolism of PNS bacteria consists of several main components; the enzyme systems, the carbon flow (TCA cycle) and the photosynthetic membrane apparatus. These components are found in close interaction via exchange of protons, electrons and ATP during metabolic processes in the cell (Koku et al., 2002). Figure 1.3 shows the carbon metabolism of PNS bacteria.

The oxidation of organic subtrates in TCA cycle gives off electrons, protons and carbondioxide. The liberated protons and electrons are then carried to nitrogenase. This transfer is performed by the carrier molecules; nicotinamide adenine dinucleoide (NAD) and Ferredoxin (Vignais et al., 1985). The remaining protons are provided to nitrogenase as the result of ATP synthase activity. Finally, molecular hydrogen is evolved by reduction of protons by nitrogenase (Koku, 2002). Figure 1.4 depicts a part of hydrogen metabolism that occurs on the photosynthetic membrane of PNS bacteria. The overall hydrogen production metabolism is illustrated in Figure 1.5 . 


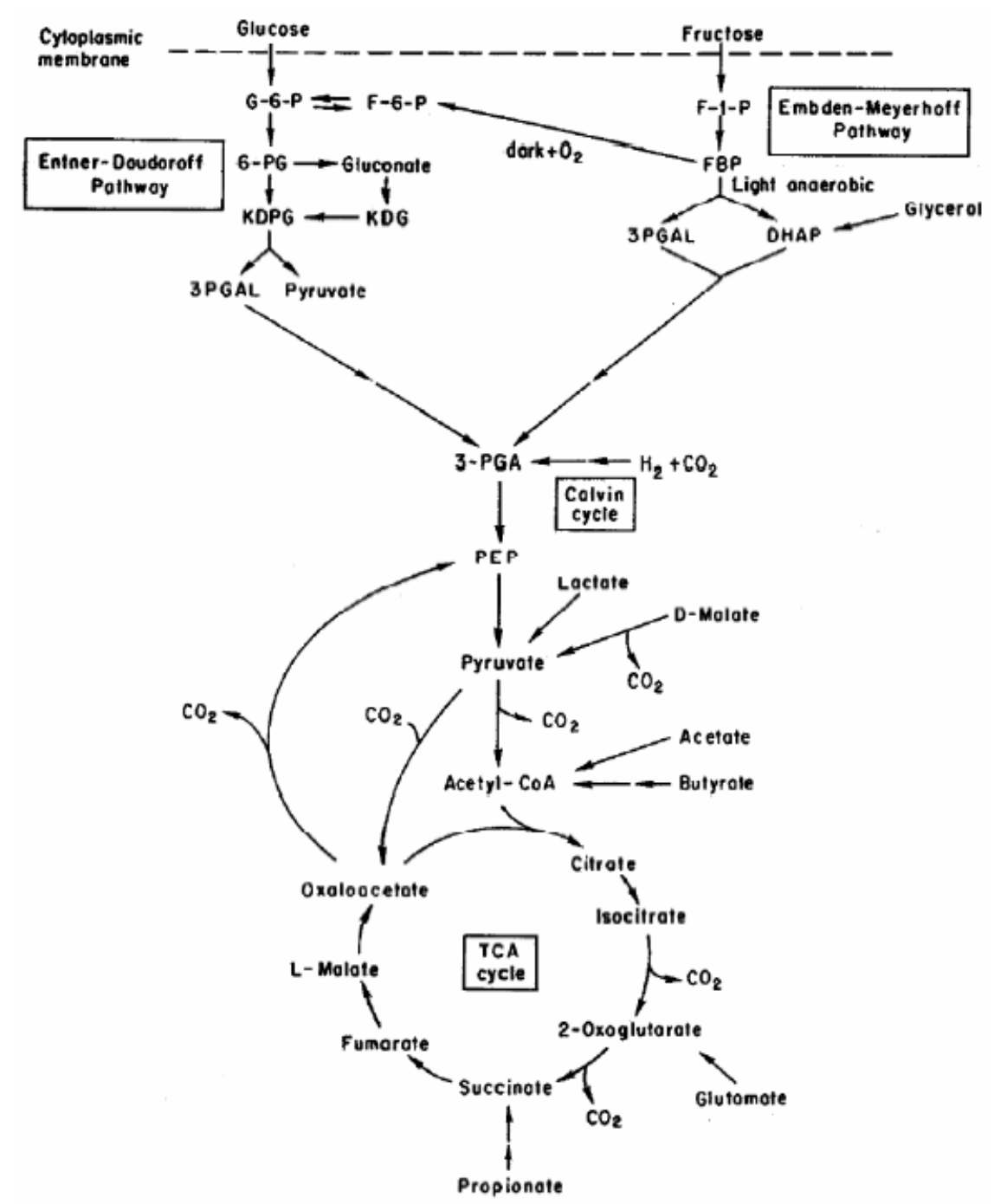

Figure 1.3 A sketch of the carbon metabolism in PNS bacteria (Koku, 2001).

\subsubsection{Nitrogenase}

Purple non-sulphur bacteria produce hydrogen via their nitrogenase enzymes. Hydrogen production is mostly obtained by nitrogenase activity. There are three different kinds of nitrogenase which have been identified depending on their active center elements. They are molybdenum centered (Mo - nitrogenase), vanadium centered (V - nitrogenase) and iron centered (Fe - nitrogenase). Four ATP is consumed for production of one mole molecular hydrogen in the absence of nitrogen 
(Basak and Das, 2007). Equation 1.1 shows the hydrogen production in the absence of nitrogen by PNS bacteria.

When molecular nitrogen is present in environment, nitrogenase reduces di-nitrogen into ammonia as a part of their nitrogen fixation pathway. Equation 1.2 shows nitrogen fixation reaction by nitrogenase activity. Many PNS bacteria have Mo nitrogenase for hydrogen production (Koku et al., 2002).

$$
\begin{gathered}
2 \mathrm{H}^{+}+2 \mathrm{e}^{-}+4 \mathrm{ATP} \rightarrow \mathrm{H}_{2}+4 \mathrm{ADP}+4 \mathrm{P}_{\mathrm{i}} \\
\mathrm{N}_{2}+8 \mathrm{H}^{+}+8 \mathrm{e}^{-}+16 \mathrm{ATP} \rightarrow 2 \mathrm{NH}_{3}+\mathrm{H} 2+16 \mathrm{ADP}+16 \mathrm{P}_{\mathrm{i}}
\end{gathered}
$$

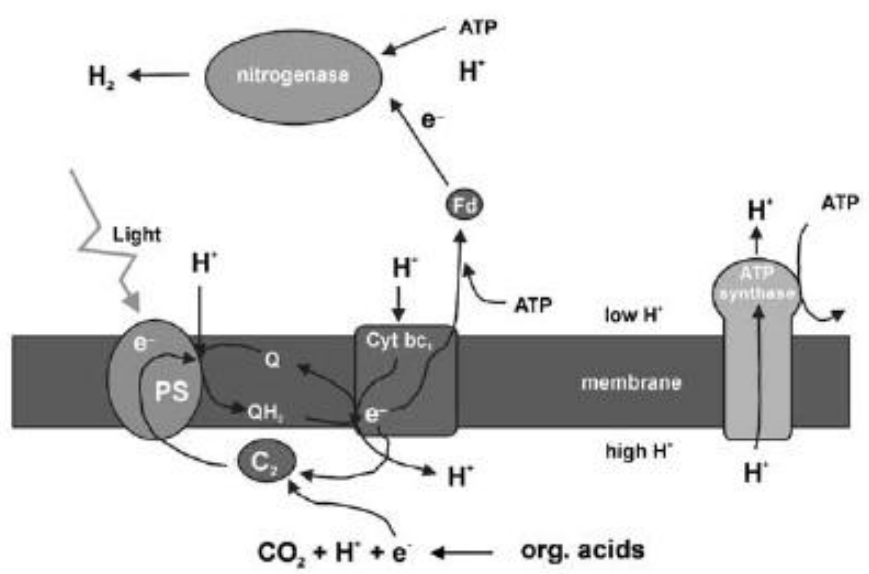

Figure 1.4 Photofermentation by PNS bacteria Akkerman et al. (2002). 


\subsubsection{Hydrogenase}

Hydrogenase is membrane-bound critical enzyme of PNS bacteria. Hydrogenase may both catalyse the production of hydrogen at small amounts and consumption of hydrogen which is produced by their metabolism (Koku et al., 2002). Hydrogenase catalyzes the reversible reaction (1.7) below.

$$
\mathrm{H}_{2} \longleftrightarrow 2 \mathrm{H}^{+}+2 \mathrm{e}^{-}
$$

Oxygen and carbon monoxide have inhibitory force on hydrogenase. Although hydrogenases of PNS bacteria generate hydrogen, most of the hydrogen in the cell is produced by the action of nitrogenase. Consumption of hydrogen by the uptake hydrogenase activity could be prevented by mutations on hydrogenase for evolution of more hydrogen from the PNS bacteria. Öztürk et al. (2006) developed a mutant strain, $R$. capsulatus YO3, which was derived from $R$. capsulatus MT 1131 by deleting uptake hydrogenase via interposon mutation and reported $70 \%$ hydrogen production efficiency. Using this strain Androga et al (2010) and Avcioglu et al (2011) reported improved hydrogen productions in outdoor panel photobioreactors using defined media and dark fermenter effluent of molasses, respectively. 


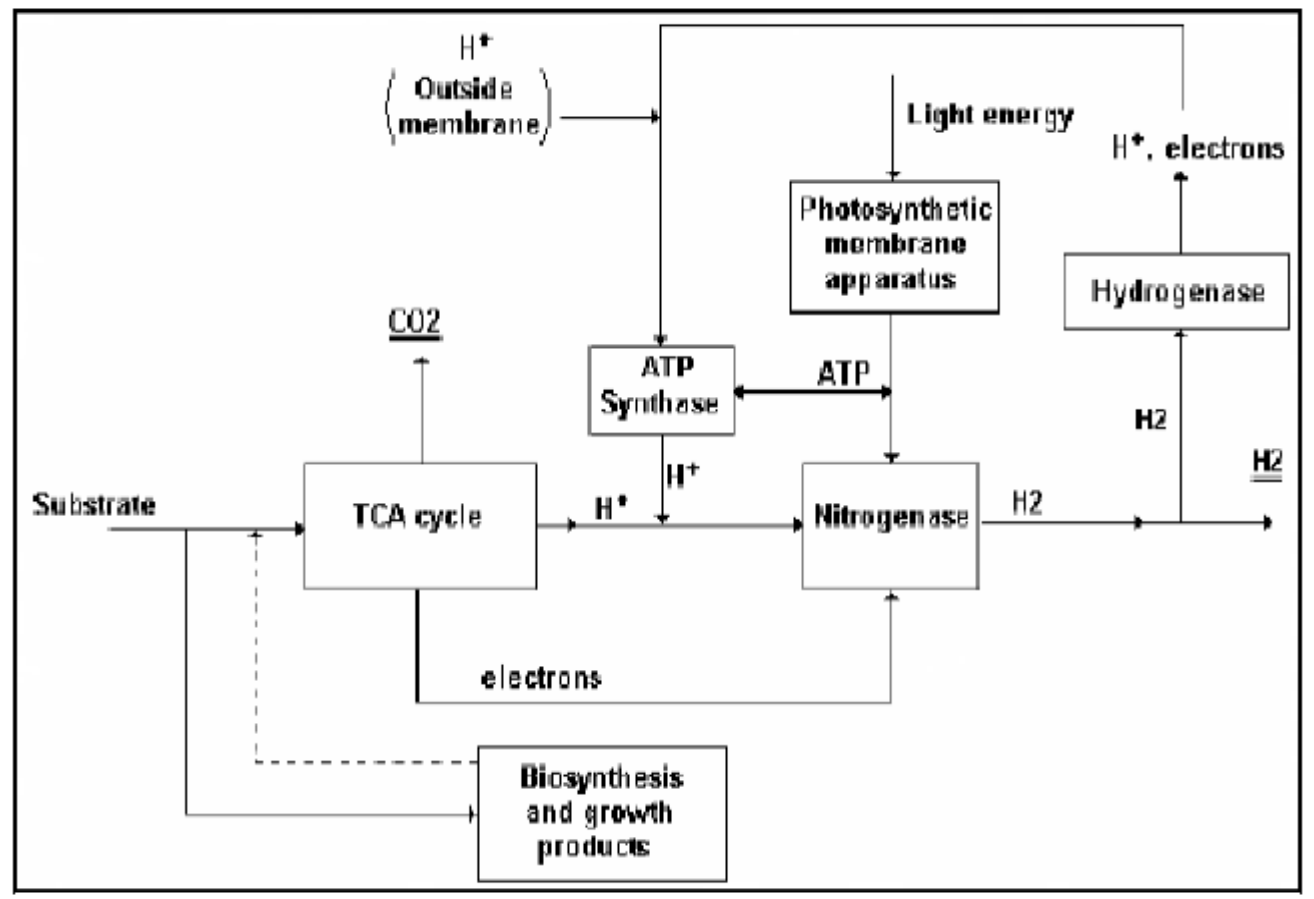

Figure 1.5 Hydrogen production metabolism of PNS bacteria (Koku et al., 2002).

\subsubsection{By-Products of Biological Hydrogen Production}

PHB is a valuable polymer of the photofermentation by-product. The accumulation of this product in the cell occurs when superfluous carbon and energy present and insufficient nitrogen for growth (Hustede et al., 1993). Poly- $\beta$-hydroxybutyrate (PHB) is synthesized for storage of carbon and energy by the bacteria. The accumulation of PHB is affected and determined by the type of substrate and $\mathrm{pH}$ of the hydrogen production medium. PHB is considered as an economical by-product since it is a biodegradable polymer. Therefore, this product may be used in different industrial applications (Koku, 2002). 
Caratenoid pigments (carotene and xanthophyll) of PNS bacteria is also accepted as a by-product of the hydrogen production process. They protect the bacteria from photoinhibitory effect of the sun and enhance light energy absorption of bacteriochlorophyll which is photosynthetic pigment of photosynthetic bacteria. They have potential usages in medical and food industry (Androga, 2009).

\subsection{Molasses as a Feedstock for Hydrogen Production}

The biological hydrogen are generated especially by anaerobic dark fermentation, photofermentation and combined systems with microorganisms. Different sources of materials were investigated and used for hydrogen production in those systems. Organic biomass and wastes comprise a major part of the sources since they contain organic substrates. Biomass is a widespread renewable resource for energy production. The biomass is produced by either agricultural or industrial processes. Energy crops such as sugar cane, sugar beet and corn are common plants used in energy production. The conversion of energy from biomass occurs in two ways; thermal or biological methods (Claassen et al., 1999).

Sugar beet molasses is a source of sucrose which can be used as substrate in anaerobic dark and photofermentative hydrogen production processes. Molasses is obtained by repeated crystallization of raw sugar in refineries during the sugar production. They are the final effluents before the refined sugar production. Molasses, the end product in sugar factories, contain of $12-17 \%$ water and $49 \%$ sucrose. Sucrose is predominantly present in molasses rather than other carbohydrates such as glucose, fructose and raffinose (Olbrich, 1963).

Hydrogen production on sucrose was studied abundantly in dark fermentative processes (Chen et al., 2001). The produced compounds in the effluent was used as substrate for the photofermentative process. (Tao et al., 2007; Özgür et al., 2010). 
Therefore, sequential production systems could be applied for the maximum utilization of sucrose or other organic compunds.

Bolliger et al. (1985) studied with several photosynthetic non-sulphur bacteria for photoproduction of hydrogen by using a sugar refinery wastewater. They used sugar containing wastewater as carbon source for the bacteria and the yield of produced hydrogen was $0.011 \mathrm{H}_{2} / \mathrm{h} / \mathrm{gdcw}$ with $5 \%$ wastewater.

Sunita and Mitra (1993) reported hydrogen evolution by photosynthetic non-sulphur bacteria isolated from a wastewater pond by using different organic compunds as carbon sources. Rhodopseudomonas sp. (SM1NSOU) was chosed for hydrogen production since it was the fast-growing bacterial culture. Total hydrogen for $1 \mathrm{lt}$ substrate was, $214 \mathrm{ml}$ for waste water and $290 \mathrm{ml}$ for sewage.

Tanisho and Ishiwata (1994) obtained the maximum hydrogen production rate as 36 mmol- $\mathrm{H}_{2} /($ l-culture h) by Enterobacter aerogenes in a $300 \mathrm{ml}$ fermenter containing $250 \mathrm{ml}$ diluted molasses of which $2 \%$ were sugars.

Uchiyama et al. (1996) studied with Rhodopseudomonas sp. using effluents from an anaerobic reactor fed with sugar wastewater effluents as carbon sources and obtained the maximum hydrogen rate as $0.1261 \mathrm{H}_{2} / \mathrm{h} / \mathrm{gdcw}$.

Türkarslan et al. (1998) reported photobiological hydrogen production by the wastewater of milk industry with $R$. sphaeroides O.U.001. This bacteria utilized 3fold diluted wastewater as carbon source and produced $85 \mathrm{ml}$ hydrogen through 90 hours process in a $150 \mathrm{ml}$ cylindirical glass column bioreactor.

Yiğit et al. (1999) studied hydrogen production from a sugar factory waste water using R. sphaeroides O.U.001. Hydrogen medium was formed by $30 \%$ waste water in $50 \mathrm{ml}$ flasks. The amount of produced hydrogen was $35 \mathrm{ml}$ in 108 hours at $36{ }^{\circ} \mathrm{C}$ and under $200 \mathrm{~W} \mathrm{~m}^{-2}$ illumination. 
Yetis et al. (2000) reported photoproduction of hydrogen from a pretreated sugar refinery waste water by R. sphaeroides O.U.001 in a column reactor. They obtained maximum hydrogen production as $2.67 \mathrm{l}$ at a dilution rate of $0.0013 \mathrm{~h}^{-1}$.

Sung et al. (2002) studied hydrogen production by anaerobic microbial culture using pure sucrose as substrate. The hydrogen yield was $1.5291 \mathrm{~mole}_{2} /$ mole sucrose. Clostridium and Bacillus species was dominant in the microbial community. They found that $\mathrm{pH} 5.5$ was optimum for the operation in continuous-flow bioreactors.

Hussy et al (2005) studied continuous fermentative hydrogen production from sucrose and sugar beet using anaerobically digested sewage sludge. For refined sucrose, $1.7 \pm 0.2 \mathrm{~mol} / \mathrm{mol}$ hexose were obtained with a nitrogen sparging 2.31 working volume of CSTR reactor.

Zhang et al. (2005) showed the effect of iron concentrations by mixed bacteria on hydrogen production with sucrose. They obtained the maximum yield as 2.73 $\mathrm{mol} / \mathrm{mol}$ sucrose at $1600 \mathrm{mg} \mathrm{FeSO} \mathrm{ll}^{-1}$.

Ren et al. (2006) reported the maximum hydrogen production rate of $5.57 \mathrm{~m}^{3} \mathrm{H}_{2} / \mathrm{m}^{3}$ reactor/d in a continuous flow anaerobic reactor with a volume of $1.48 \mathrm{~m}^{3}$ for 200 days operation.

$\mathrm{Xu}$ et al. (2007) investigated the effects of pre-treatment methods of molasses in anaerobic systems. They reported that yeast extract increased fermentability and hydrogen yield by Ethanoligenens sp. B49. The hydrogen yield was $78.97 \mathrm{mmol} / \mathrm{l}_{\mathrm{c}}$. They also showed that molasses of $4 \mathrm{~g} / \mathrm{l}$ was found as optimum concentration.

Li et al. (2007) studied hydrogen production from diluted molasses by anaerobic bacteria in a 27.481 effective volume of anaerobic baffled reactor (ABR) for 26 days. The initial $\mathrm{pH}$ was adjusted as 6.6 and molasses were diluted to $5000 \mathrm{mg} / \mathrm{l} \mathrm{COD}$ level. The hydrogen yield was obtained as 32.51 1/day.

$\mathrm{Xu}$ et al. (2007) studied hydrogen production from molasses with a fermentative strain, Ethanoligenens sp. B49. They reported that feasible COD of molasses was 
$20.6 \mathrm{~g} / \mathrm{l}$ and also showed that addition of nitrogen increased hydrogen production. The yield of hydrogen was raised up from $44.82 \mathrm{mmol} / \mathrm{l}$ to $78.97 \mathrm{mmol} / \mathrm{l}$ by applying optimal concentrations of molasses.

Wang et al. (2009) reported maximum hydrogen production yield of 1.85 mol $\mathrm{H}_{2} /$ mol hexose by Clostridium butyricum W5 using $100 \mathrm{~g} / \mathrm{l}$ molasses at $39{ }^{\circ} \mathrm{C}$ and $\mathrm{pH}$ of 6.5 as initial level in a laboratory scale batch bioreactor with a working volume of 1.51 .

Özgür et al. (2010) studied on hydrogen production by sequential dark and photofermentation with sucrose from sugar beet molasses as carbon source. The yield of hydrogen was increased from $4.2 \mathrm{~mol} \mathrm{H}_{2} / \mathrm{mol}$ sucrose in dark fermentation by 13.7 mol $\mathrm{H}_{2} / \mathrm{mol}$ sucrose by the sequential process.

Li et al. (2011) reported the highest hydrogen production of $11.39 \mathrm{l} / \mathrm{d}$ using mixed culture fermentation with molasses wastewater in a CSTR at $35^{\circ} \mathrm{C}$.

Özkan et al. (2011) studied photofermentative hydrogen production by dark fermenter effluent of sugar beet thick juice in solar 41 fed-batch panel photobioreactors using $R$. capsulatus YO3 (Hup ${ }^{-}$). The productivity of hydrogen was $1.12 \mathrm{mmol} / \mathrm{L}_{\mathrm{c}} / \mathrm{h}$ through 15 days of process.

Avcioglu et al. (2011) reported biological hydrogen production using dark fermenter effluent of molasses by PNS bacteria. They achieved maximum hydrogen productivity as $0.50 \mathrm{mmol} \mathrm{H}_{2} / \mathrm{L}_{\mathrm{c}} \cdot \mathrm{h}$ and $0.67 \mathrm{mmol} \mathrm{H}_{2} / \mathrm{L}_{\mathrm{c}}$.h by $R$. capsulatus DSM 1710 and R. Capsulatus YO3 (Hup`) respectively.

Chu et al. (2011) reported maximum biohydrogen production rate with suspended sludge bioreactor 1.21 (SSB) and immobilized cell bioreactor (ICB) systems with condensed molasses solubles. The hydrogen rate was $14.04 \pm 2.08$ for SSB and 7.60 $\pm 1.05 \mathrm{l} / \mathrm{d}$ on $40 \mathrm{~g} \mathrm{COD} / 1$. 
Qu et al. (2012) reported the increase of hydrogen yield from $1.76 \mathrm{l} / \mathrm{d}$ to $6.45 \mathrm{l} / \mathrm{d}$ in a continuous two-stage (dark-dark) fermentation system from molasses wastewater with two 9.2 1 CSTRs.

\subsection{Co-cultivation of PNS Bacteria}

One of the options for the enhancement of hydrogen productivity is co-cultivation of the microorganisms in hydrogen production medium. Improvement of hydrogen production by the syntrophic interactions between different bacteria are considered as an interesting research area in recent years (Fang et al., 2006). The interaction of the bacteria in the same media has a great importance for the fate of hydrogen production, growth and $\mathrm{pH}$ change through the operation time. Co-cultivation was applied for both dark and photofermentative bacteria on glucose as the hydrogen production substrate (Zhu et al., 2001; Miyake et al., 1984).

Co-cultivation of Rhodobacter sphaeroides and Lactobacillus delbrueckii was applied as co-immobilized cultures and $7.1 \mathrm{~mol}_{2}$ was produced per mole of glucose (Asada et al., 2006).

Fang et al. (2006) studied co-culture of Clostridium butyricum and Rhodobacter sphaeroides on glucose by photofermentation. The FISH method was also shown as an effective method in the quantification of bacteria in co-cultivation studies.

\subsection{Scope of The Thesis}

The objective of this study was to produce photobiological hydrogen by utilization of sugar beet molasses via direct photofermentation process. Molasses contain high 
amount of sucrose, which can be utilized by PNS bacteria for growth and hydrogen production. The raw molasses obtained from Etimesgut Sugar Factory (Ankara, Turkey) was used as substrate after 40, 60 and 80 fold dilutions.

Four different photosynthetic PNS bacteria (Rhodobacter capsulatus (DSM 1710), Rhodobacter capsulatus YO3 (Hup'), Rhodopseudomonas palustris (DSM 127) and Rhodobacter sphaeroides O.U.001 (DSM 5864)) were used for biological hydrogen production.

Studies were carried out starting with adaptation of the PNS bacteria to sucrose. After the adaptation studies, growth and hydrogen production on defined sucrose media were tested. Then, molasses were diluted to certain sucrose concentrations and they were also used for growth and hydrogen production of PNS bacteria.

In addition, hydrogen production was performed by co-cultivation of these bacteria on sucrose from molasses. Modes of $\mathrm{pH}$, growth and hydrogen production of the bacteria in bioreactors were examined and compared in.

The process provided not only a clean fuel, hydrogen, but also contributed cleaning of environment by performing waste treatment. Such a bioremediative aid by preventing pollution and providing recyclability, was considered as remarkable for a green earth. 


\section{CHAPTER 2}

\section{MATERIALS AND METHODS}

\subsection{Materials}

\subsubsection{Bacterial Strains}

Four different bacterial strains were used in this study. Rhodobacter capsulatus (DSM 1710), Rhodopseudomonas palustris (DSM 127) and Rhodobacter sphaeroides O.U.001 (DSM 5864) strains were taken from DSMZ (Deusche Sammlung von Mikroorganismen und Zellkulturen GmbH - German Collection of Mikroorganisms and Cell Cultures, Germany). Rhodobacter capsulatus YO3 (Hup), a mutant strain lacking the uptake hydrogenase, was genetically modified by Dr. Yavuz Öztürk (GMBE, TÜBİTAK-MAM, Gebze) from Rhodobacter capsulatus MT 1131 (Öztürk et al., 2006).

\subsubsection{Chemicals}

Potassium dihydrogen phosphate, magnesium sulfate heptahydrate, Calcium chloride dihydrate, Monosodium glutamate, Agar, Sucrose, Iron-citrate, Vitamin, Trace elements were the chemicals used in the experiments and obtained from MERCK Chemicals. The list of the chemicals are given in Appendix A.

Raw molasses were obtained from sugar factory (Ankara Şeker Fabrikası) in Ankara, Turkey. The composition of molasses is given in Appendix F. 


\subsubsection{Solid Media}

Solid media was used for activation and contamination detection of bacteria in stocks. Solid media is formed by addition of agar $(1 \% \mathrm{w} / \mathrm{v})$ to the growth media. The solid media was prepared by dissolving agar in the growth medium before autoclaving the media. After sterilization process, the media was poured into agar plates. Bacterial inoculation was performed when solidification of agar is completed.

\subsection{Methods}

\subsubsection{Growth Media}

Biebl and Pfennig (1981) medium with acetate $(20 \mathrm{mM})$ and glutamate $(10 \mathrm{mM})$ as carbon and nitrogen sources respectively, was used for the bacterial growth. The ingredients of the medium were dissolved in distilled water and initial $\mathrm{pH}$ was adjusted to $6.4-6.5$ by titrating with $\mathrm{NaOH}$. The medium was sterilized by autoclaving for 20 minutes at $121{ }^{\circ} \mathrm{C}$. Vitamins, trace elements and iron-citrate were other components which were added after cooling the solution. The ingredients of growth medium is given in Appendix A.

\subsubsection{Sucrose-Adaptation Media}

The PNS bacteria were adapted to sucrose using two extra steps. After growing of the bacteria in acetate-glutamate $(20 / 10 \mathrm{mM})$ medium, they were transferred into a second growth medium with acetate-sucrose-glutamate (20/10/10 $\mathrm{mM})$ and then the bacteria were finally inoculated into sucrose-glutamate $(10 / 10 \mathrm{mM})$ medium. When the optical density was nearly 2.0 at $660 \mathrm{~nm}$, the culture was used for hydrogen production. Glutamate $(10 \mathrm{mM})$ was used as nitrogen source for all the growth media (Table 2.1). 
Table 2.1 The growth media of PNS bacteria for activation (1), and adaptation of bacteria to sucrose, (2) and (3).

\begin{tabular}{|c|c|c|c|}
\hline Growth media & Acetate $(\mathbf{m M})$ & Sucrose $(\mathbf{m M})$ & Glutamate (mM) \\
\hline 1 & 20 & - & 10 \\
\hline 2 & 10 & 20 & 10 \\
\hline 3 & - & 10 & 10 \\
\hline
\end{tabular}

\subsubsection{Hydrogen Production Media}

Hydrogen production media were based on sucrose as the substrate. Different sucrose concentrations (5-7.5-10 $\mathrm{mM}$ ) were used as carbon source in the experiments. Firstly, pure sucrose was used for defined hydrogen media. Glutamate $(2 \mathrm{mM})$ was the nitrogen source of the bacteria. Secondly, molasses was diluted to obtain sucrose concentrations of $5 \mathrm{mM}, 7.5 \mathrm{Mm}$ and $10 \mathrm{mM}$ (Table 2.2) and used for hydrogen production.

Table 2.2 Dilutions carried out on molasses feedstock to obtain desired sucrose concentrations.

\begin{tabular}{|c|c|}
\hline Concentration of Sucrose & $\begin{array}{c}\text { Dilution Factors of } \\
\text { Molasses }\end{array}$ \\
\hline $5 \mathrm{mM}$ & $80 \mathrm{X}$ \\
\hline $7,5 \mathrm{mM}$ & $60 \mathrm{X}$ \\
\hline $10 \mathrm{mM}$ & $40 \mathrm{X}$ \\
\hline
\end{tabular}

\subsection{Experimental Setup}


Experiments for hydrogen production were performed in $55 \mathrm{ml}$ glass bottles. The glass bottles were used as photobioreactors which contained of $45 \mathrm{ml}$ of hydrogen production media and $5 \mathrm{ml}$ of bacterial culture. The transfer of the medium and culture into the glass reactors were done in a sterile cabinet. Sterilization of the glass bottles and brown caps were achieved by autoclaving. Argon gas was flushed through the top of brown caps by a needle to make the environment fully anaerobic. The photobioreactors (PBRs) were kept at $30{ }^{\circ} \mathrm{C}$ in an incubator (Nüve, ES250). The illumination of the system was ensured by 60-100 W tungsten lamps. Light intensity of the reactors were adjusted by a luxmeter (Lutron LX-105). The produced gas was collected in volumetric cylindirical glass tubes and measured through of water. Experimental setup is shown in Figure 2.1.

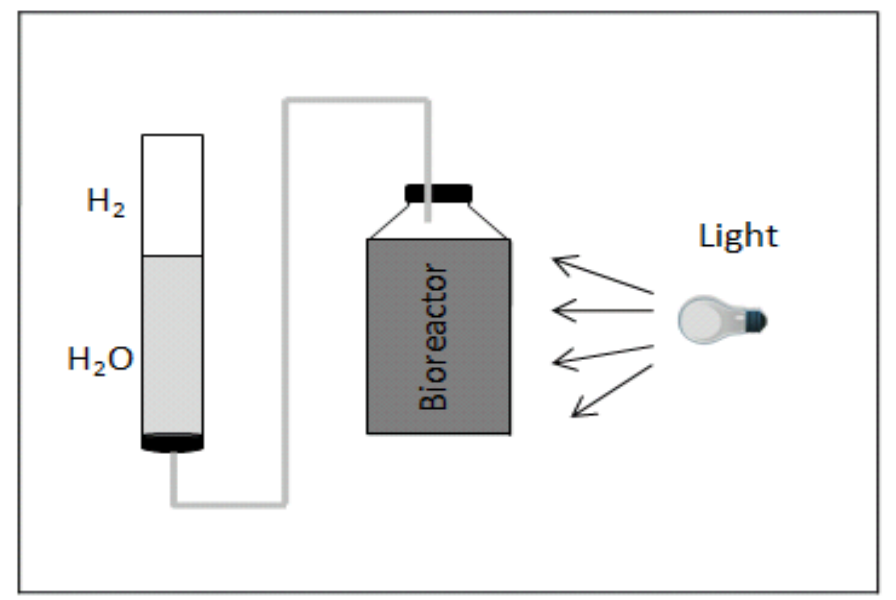

Figure 2.1 Schematic illustration of experimental setup. 


\subsection{Hydrogen Production Procedure}

The bacterial stock culture which were stored in deep freezer at -80 were activated by streak plate method. Firstly, the original stock bacteria were transferred to plates containing solid growth medium that are composed of agar solution with $20 \mathrm{mM}$ acetate and $10 \mathrm{mM}$ glutamate in a laminar chamber. Then, the agar plates were incubated for growth at a temperature of about $30{ }^{\circ} \mathrm{C}$ and an illumination of 20002200 lux by using tungsten lamps. After 5-7 days, a grown bacterial colony was taken and then inoculated into $2 \mathrm{~mL}$ eppendorfs which contain agar free liquid growth medium. The inoculation was done at mid logarithmic phase of the growth which corresponds to around 1.0-1.5 optical density at $660 \mathrm{~nm} .10 \%(\mathrm{v} / \mathrm{v})$ inoculum was injected into the liquid growth medium by means of a sterile syringes.

The bioreactors were filled with $5 \mathrm{ml}$ of bacterial culture and 45 of ml hydrogen production medium. Then, they were placed into cooling incubators and operated for 7-10 days. All the steps were performed in sterile cabinets.

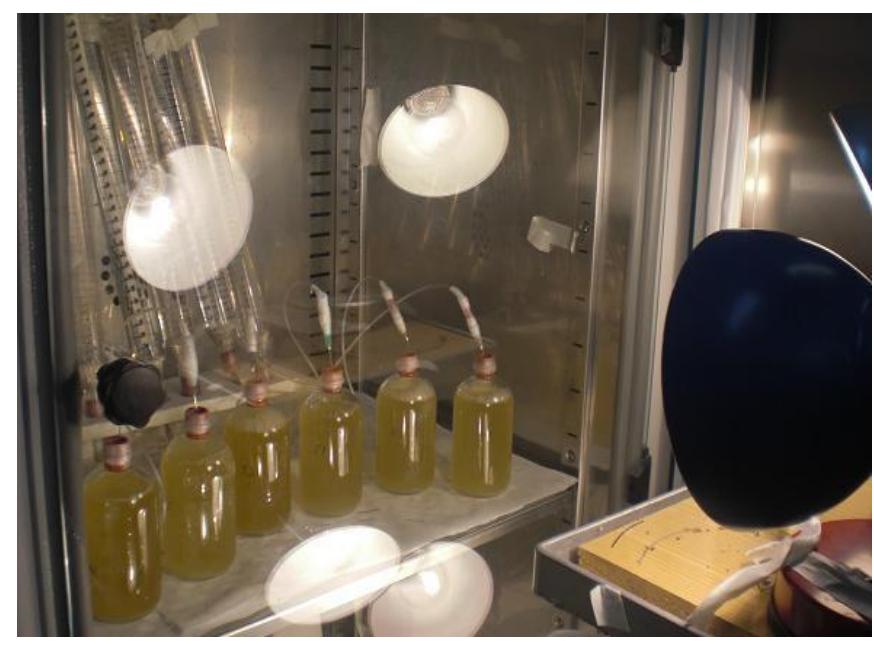

Figure 2.2 The picture of experimental setup for hydrogen production. 


\subsection{Analyses}

\subsection{1 pH Analysis}

A pH-meter (Mettler Toledo 3311) was used to measure $\mathrm{pH}$ of the liquid samples taken from the PBRs. Standard buffer solutions at $\mathrm{pH}$ of 4.0, 7.0 and 9.2 were used for calibration of the $\mathrm{pH}$-meter before measuring each samples.

\subsubsection{Cell Concentration}

Growth of the bacteria was monitored by a spectrophotometer (Shimadzu UV-1201) at $660 \mathrm{~nm}$ wavelength. Optical densities of the samples were measured using a fresh medium as the blank solution. Cell concentrations were determined by conversion of absorbance values to dry cell weights (Uyar, 2008). For calculation of dry cell weights, the calibration curve was used (Appendix B).

\subsubsection{Analysis of Sugar and Organic Acids}

Sugar analysis was performed by using High Performance Liquid Chromatography (HPLC, Shimadzu 10A) in the Chemical Engineering Department at the Middle East Technical University, Ankara, Turkey. Transgenomic, CARBOSep CHO-682 Lead column was used with a refractive index detector. Filtered samples $(5 \mu \mathrm{L})$ were injected with an autosampler (Shimadzu SIL-10AD) In the analysis, ultra pure water was used as the mobile phase with a flow rate of $0.25 \mathrm{~mL} / \mathrm{min}$. The oven temperature was maintained at $80{ }^{\circ} \mathrm{C}$ during the analysis. Alternatively, HPLC analysis for sugar was carried out using Inertsil $\mathrm{NH}_{2}(250 \mathrm{~mm} \times 4.6 \mathrm{~mm})$ column with mobile phase of acetonitrile:water (75:25). The oven temperature was set to $40{ }^{0} \mathrm{C}$ and $1.1 \mathrm{ml} / \mathrm{min}$ mobile phase flow was provided through the analysis. Appendix $\mathrm{C}$ is given as a sample chromatogram and a calibration curve for sucrose. 
Organic acid contents in the samples were analyzed by HPLC (Shimadzu 20A). Alltech I0A-1000 (300 mm x $7.8 \mathrm{~mm}$ ) ion-exchange column was used to detect organic acids in the liquid samples. An autosampler (Shimadzu SIL-10AD) was provided for the injection of $20 \mu \mathrm{L}$ samples and the detection of organic acids was determined by a UV detector (Shimadzu FCV-10AT) at $210 \mathrm{~nm}$. The oven temperature was maintained at $66{ }^{\circ} \mathrm{C}$ and $0.085 \mathrm{M} \mathrm{H}_{2} \mathrm{SO}_{4}$ was used as mobile phase in the system. Flow rate of the mobile phase was set to $0.4 \mathrm{ml} / \mathrm{min}$. Calibration curves were constructed for standard organic acids at different concentrations. A sample chromatogram and a calibration curve is shown in Appendix D. Organic acids remaining or produced during the process were acetic acid, lactic acid, butyric acid, propionic acid, formic acid and malic acid.

\subsubsection{Analysis of Gas Composition}

The composition of the total gas produced by bioreactors was analyzed by gas chromatography (GC, Agilent Technologies 6890N). The gas chromatography device was equipped with a thermal conductivity detector and a column (Supelco Carboxen 1010). Gas composition analysis was performed with a flow rate of 25 $\mathrm{mL} / \mathrm{min}$ by using argon gas as the carrier gas in the system.

A micro gas syringe (Hamilton, 22 GA $500 \mu \mathrm{L}$ ) was used for injection of the gas sample to the GC system. The gas sample $(100 \mu \mathrm{L})$ taken from gas collector. The oven, injector and detector temperatures were $140{ }^{0} \mathrm{C}, 160{ }^{0} \mathrm{C}$ and $170{ }^{0} \mathrm{C}$, respectively. A representative gas analysis chromatogram is given in Appendix E. 


\subsubsection{Molasses Composition and Pretreatment of Molassses}

Molasses was taken from a sugar factory in Ankara, Turkey (Ankara Sugar Factory). Their components were analyzed in Düzen Norwest Laboratory, Ankara, Turkey. Total aminoacids, alcohol (Ethyl alcohol), phenol and minerals (Fe, Mo, S, K) were the parameters analyzed. Sugar composition and organic acid analysis were carried out by HPLC in the METU Molecular Biology \& Biotechnology Research and Development Center. The results of the analyses is given in Table 2.3. A detailed table of undiluted molasses composition analysis is given in Appendix F.

Table 2.3 The composition of undiluted molasses used in the experiments.

\begin{tabular}{|l|c|c|}
\hline \multicolumn{1}{|c|}{ Component } & Units & Concentration \\
\hline Sucrose & $\mathrm{M}$ & 1.16 \\
\hline Alcohol (ethyl alcohol) & $\%(\mathrm{v} / \mathrm{v})$ & 0.16 \\
\hline Phenol & $\mathrm{mg} / \mathrm{L}$ & 25.4 \\
\hline Lactic acid & $\mathrm{mg} / \mathrm{mL}$ & 7.58 \\
\hline Iron (Fe) & $\mu \mathrm{g} / \mathrm{L}$ & 516.9 \\
\hline Molybdenum (Mo) & $\mu \mathrm{g} / \mathrm{L}$ & 99.7 \\
\hline Sulphur (S) & $\mathrm{mg} / \mathrm{L}$ & 187.1 \\
\hline Potassium (K) & $\mathrm{mg} / \mathrm{L}$ & 5365 \\
& & \\
\hline
\end{tabular}




\subsection{Data Analysis and Calculations}

In the evaluation of the hydrogen production analysis, there are some important parameters such as substrate conversion efficiency, hydrogen productivity and light conversion efficiency.

Substrate conversion efficiency was calculated by the formula below;

The substrate was sucrose either as pure or on molassses with different concentrations in this study. Equation 2.1, is the efficiency of the substrate conversion was determined by the ratio of mole of theoretical hydrogen production over consumed sucrose to experimental hydrogen production amounts.

Substrate conversion efficiency $(\%)=$ (Moles of theoretically produced $\mathrm{H}_{2}$ over consumed substrate) / (Experimental moles of $\mathrm{H}_{2}$ ) x 100

Hydrogen productivity is the rate of hydrogen production through the duration of $\mathrm{H}_{2}$ production. It was calculated and the results were compared to determine the productivities of hydrogen by PNS bacteria on sucrose or molasses media.

Hydrogen Productivity $=$ Cumulative millimoles of hydrogen produced $/$ volume of culture (l) x t (hour)

Light Conversion efficiency is defined as the ratio of the total produced energy of hydrogen to the total energy input to the photobioreactor by light radiation. Light conversion efficiency is calculated by the formula below (2.3);

$$
\eta(\%)=\frac{33.6 \times \rho_{\mathrm{H}_{2}} \times \mathrm{V}_{\mathrm{H}_{2}}}{\mathrm{I} \times \mathrm{A} \times \mathrm{t}} \times 100
$$


Hydrogen density is $0.089 \mathrm{~g} / \mathrm{l} . \mathrm{V}_{\mathrm{H} 2}$ is the volume of produced hydrogen in L. The constant number 33.6 is the energy density of hydrogen in Watt.h/g. I, is the value of conversion of lux to $\mathrm{Watt} / \mathrm{m}^{2}$. A, is the irradiated area of photobioreactors. It is 0.002 $\mathrm{m}^{2}$ and $0.011 \mathrm{~m}^{2}$ for $50 \mathrm{ml}$ and $150 \mathrm{ml}$ bioreactors, respectively. Hydrogen production time, $\mathrm{t}$ is in hour.

Appendix I is given for sample calculations of substrate conversion efficiency, hydrogen productivity and light conversion efficiency. 


\section{CHAPTER 3}

\section{RESULTS AND DISCUSSION}

Photofermentative hydrogen production using sucrose and molasses feedstock as sole carbon source was studied. Hydrogen production by photofermentative PNS bacteria on various organic acids is well characterized. Although they can also consume sugars, hydrogen production on sugars has not been studied in detail. The strains used in this study were adapted to grow and produce hydrogen on organic acids, as well. For this reason, adaptation of the bacteria to sucrose was necessary and the present study started with the optimization of growth and hydrogen production conditions of purple non-sulphur (PNS) bacteria on sucrose as sole carbon source. The results of adaptation studies of PNS bacteria on sucrose was given in section 3.1. Growth and hydrogen production of different PNS bacteria on sucrose and molasses were discussed and compared in sections 3.2, 3.3 and 3.4. Finally, the results of cocultivation experiments were given in section 3.5.

\subsection{Optimization of Purple Non-sulphur (PNS) Bacterial Growth on Sucrose}

In this part, results of the adaptation studies of PNS bacteria to sucrose were given. Various sucrose, acetate and mixture of sucrose-acetate concentrations were tested for $R$. capsulatus (DSM1710) and R. capsulatus YO3 (Hup'). The biomass growth, hydrogen production capacities and $\mathrm{pH}$ modes of these strains were determined and 
compared. Ideal sucrose and buffer concentrations were found for optimum growth and hydrogen production.

\subsubsection{Adaptation of PNS Bacteria to Sucrose as Carbon Source}

The PNS bacteria, which were previously grown on acetate containing growth medium, were adapted to sucrose through several inoculation steps, where acetate concentration was decreased while sucrose concentration was increased in each inoculation step. After growing of the bacteria in acetate-glutamate $(20 / 10 \mathrm{mM})$ medium, they were transferred into a second growth medium containing acetatesucrose-glutamate $(20 / 10 / 10 \mathrm{mM})$. Then the bacteria were inoculated into sucroseglutamate $(10 / 10 \mathrm{mM})$ medium. When the optical density was nearly 2.0 at $660 \mathrm{~nm}$, the culture was transferred to hydrogen production medium. All the experiments were carried out in anaerobic conditions under illumination.

\subsubsection{The Effect of Sucrose on Growth}

in $50 \mathrm{ml}$ glass photobioreactors.. Glutamate $(2 \mathrm{mM})$ was used for the nitrogen source for the bacteria. The maximum biomass for R.capsulatus (DSM1710) and R.capsulatus YO3 (Hup') were $0.74 \mathrm{~g} / \mathrm{l}_{\mathrm{c}}$ and $0.96 \mathrm{~g} / \mathrm{l}_{\mathrm{c}}$ respectively. The growth on sucrose $(20 \mathrm{mM})$ was more than acetate $(30 \mathrm{mM})$ medium for both of the strains. Figure 3.1 and 3.2 show the growth of R.capsulatus (DSM1710) and R.capsulatus YO3 (Hup ${ }^{-}$) of the cultures, respectively, during 230 hours of operation time. 


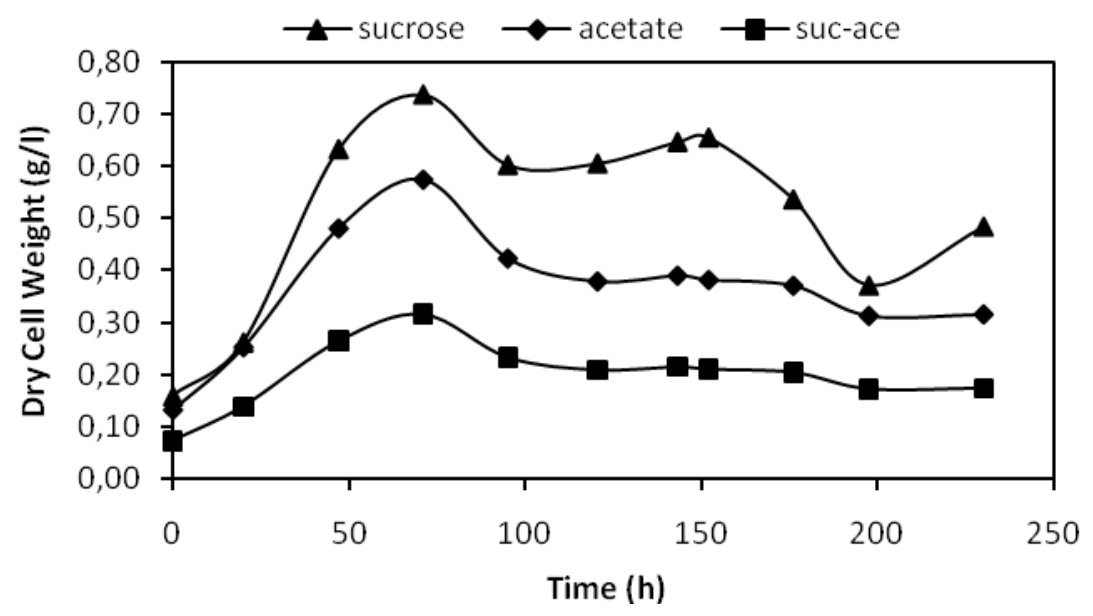

Figure 3.1 The growth of $R$. capsulatus (DSM1710) on sucrose (20 mM), acetate (30 $\mathrm{mM})$ and a mixture of sucrose-acetate $(20 \mathrm{mM} / 10 \mathrm{mM})$ defined media.

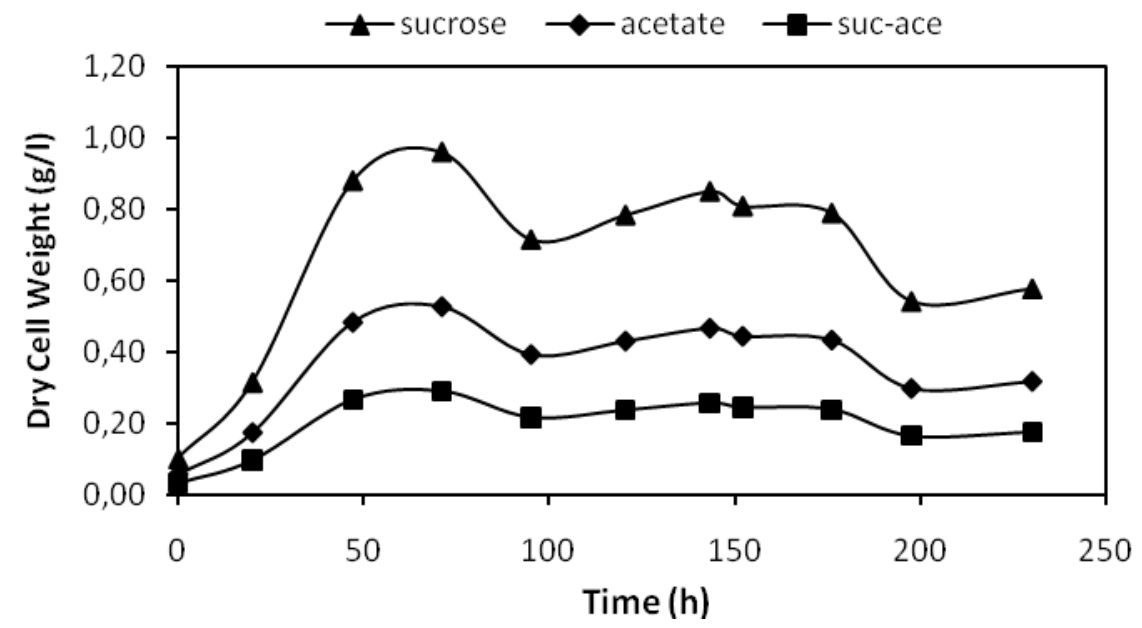

Figure 3.2 The growth of R.capsulatus YO3 (Hup-) on sucrose (20 mM), acetate (30 $\mathrm{mM})$ and a mixture of sucrose-acetate $(20 \mathrm{mM} / 10 \mathrm{mM})$ defined media. Glutamate (2 $\mathrm{mM}$ ) was the nitrogen source for all the bacteria. 
The hydrogen production levels on sucrose were lower than acetate in both strains. R.capsulatus YO3 (Hup ${ }^{-}$) produced two times more hydrogen on sucrose $(20 \mathrm{mM})$ than R.capsulatus (DSM 1710). Shown in Figure 3.3 and 3.4 are cumulative hydrogen production on different concentrations of acetate and sucrose media. Acetate showed better profile than sucrose as a substrate in hydrogen production.

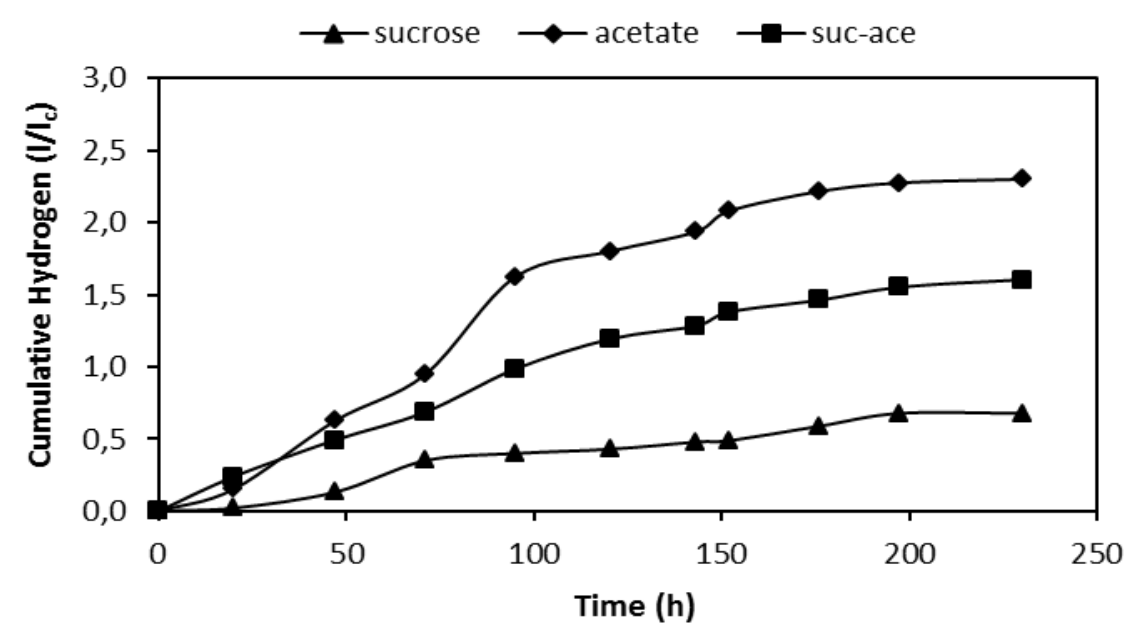

Figure 3.3 The cumulative hydrogen production of $R$. capsulatus (DSM 1710) on sucrose $(20 \mathrm{mM})$, acetate $(30 \mathrm{mM})$ and a mixture of sucrose-acetate $(20 \mathrm{mM} / 10 \mathrm{mM})$ defined media. Glutamate $(2 \mathrm{mM})$ was the nitrogen source for all the bacteria. 


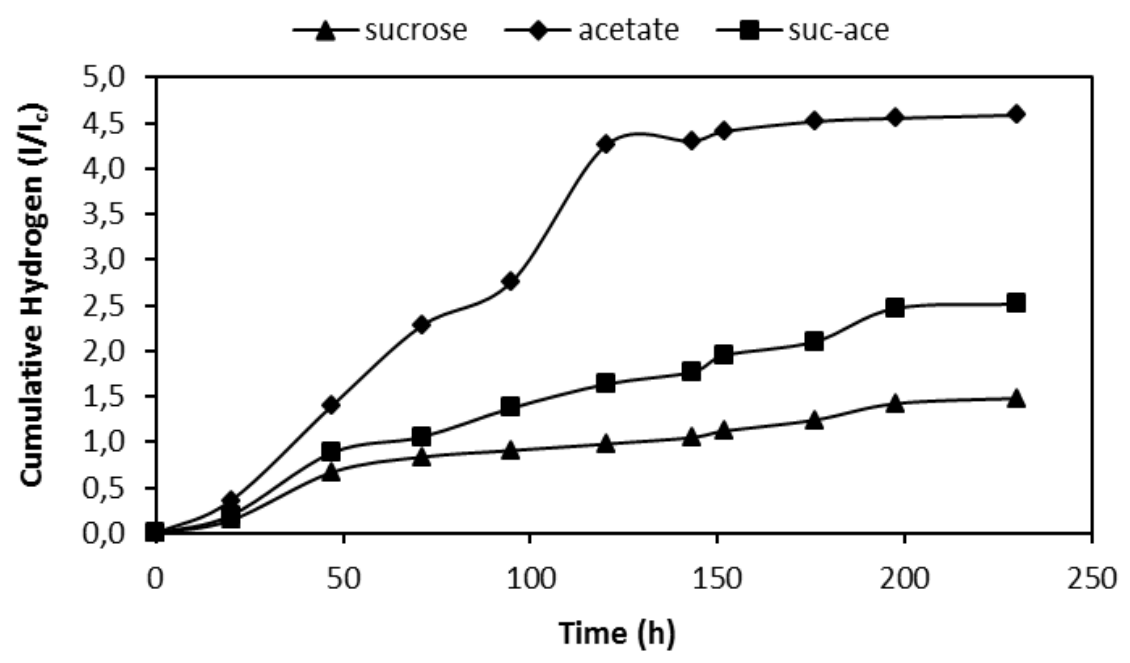

Figure 3.4 The cumulative hydrogen production of R.capsulatus YO3 (Hup-) on sucrose $(20 \mathrm{mM})$, acetate $(30 \mathrm{mM})$ and a mixture of sucrose-acetate $(20 \mathrm{mM} / 10 \mathrm{mM})$ defined media. Glutamate $(2 \mathrm{mM})$ was the nitrogen source for all the bacteria.

The variations in $\mathrm{pH}$ during the hydrogen production process on sucrose by R.capsulatus (DSM1710) and R.capsulatus YO3 (Hup') are given in Figure 3.5. The change of $\mathrm{pH}$ was in the range of 5.0-6.5. Produced organic acids may cause drops in $\mathrm{pH}$ during the process. Acetic acid and formic acid were produced abundantly as intermediates (Appendix $\mathrm{H}$ ).

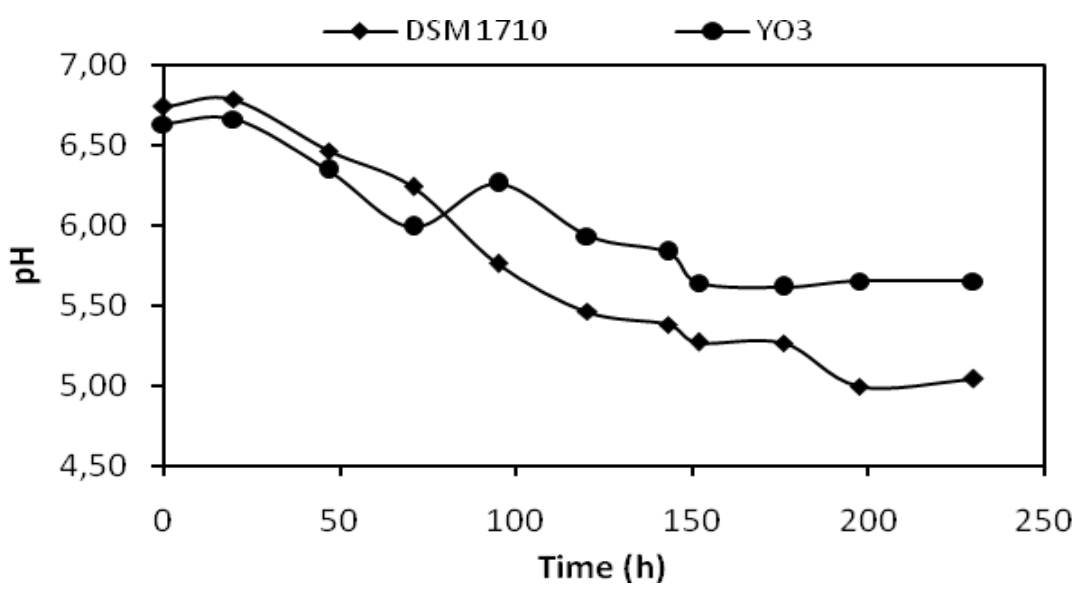

Figure 3.5 The changes of $\mathrm{pH}$ on $20 \mathrm{mM}$ sucrose media by R.capsulatus DSM 1710 and R.capsulatus YO3 (Hup-). 
This study also showed that $R$. capsulatus $\mathrm{YO}$ (Hup ${ }^{-}$) is more promising in hydrogen production than wild type. The cumulative hydrogen production was 0.36 $\mathrm{g} / \mathrm{l}_{\mathrm{c}}$ for $R$. capsulatus (DSM1710) and $0.7 \mathrm{~g} / \mathrm{l}_{\mathrm{c}}$ for $R$. capsulatus YO3 (Hup'). Hydrogen was produced intensively through the first 48 hours at which exponential cell growth occurs.

\subsubsection{The Effect of Buffer Concentrations}

Previous study in section 3.1 showed that $\mathrm{pH}$ decreased during the hydrogen production process. The rapid decline and unstable $\mathrm{pH}$ mode which was observed with $20 \mathrm{mM} \mathrm{KH}{ }_{2} \mathrm{PO}_{4}$ buffer on $20 \mathrm{mM}$ sucrose media. Therefore, different $\mathrm{KH}_{2} \mathrm{PO}_{4}$ buffer concentrations $(30-40-50 \mathrm{mM})$ were used to control $\mathrm{pH}$ during the growth and hydrogen production on sucrose.

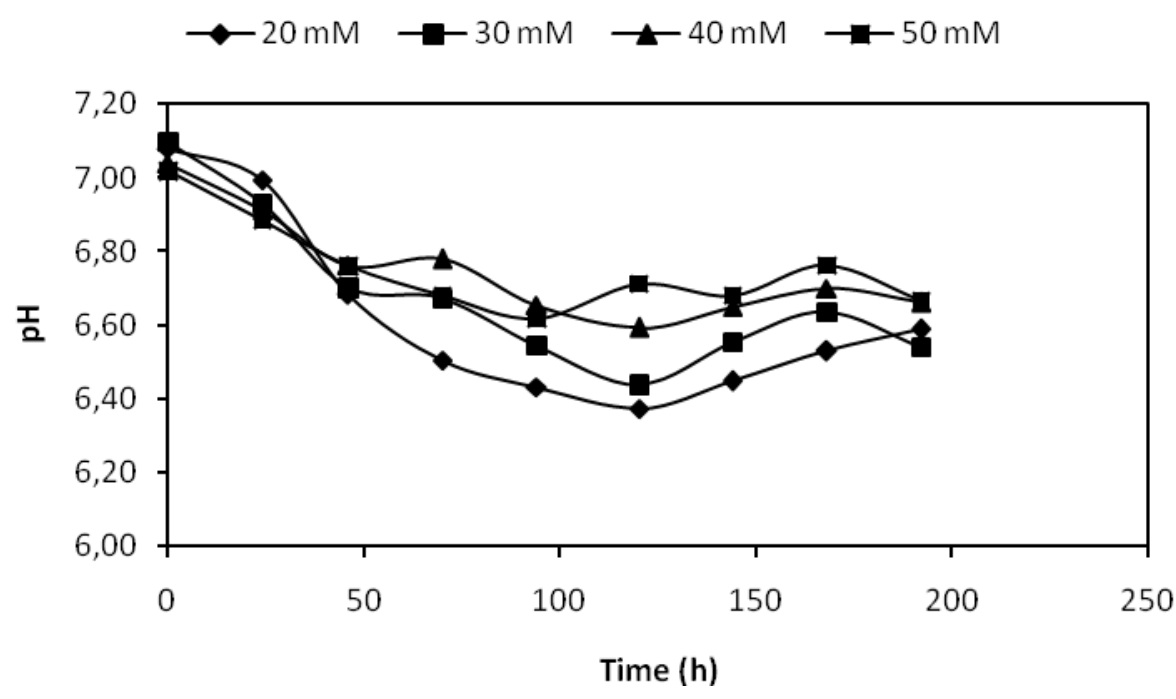

Figure $3.6 \mathrm{pH}$ curves of R.capsulatus YO3 (Hup-) in $5 \mathrm{mM}$ sucrose defined medium (DF) which is prepared by different concentrations of $\mathrm{KH}_{2} \mathrm{PO}_{4}$ buffers (initial $\mathrm{pH}$ was 7.0) 
Hydrogen production media were prepared with $5 \mathrm{mM}$ sucrose (DF) and various buffer concentrations by adjusting the initial $\mathrm{pH}$ as 7.0. The variation in $\mathrm{pH}$ during hydrogen production by $R$. capsulatus YO3 and $R$. capsulatus DSM 1710 are illustrated in Figure 3.6 and 3.7 respectively.

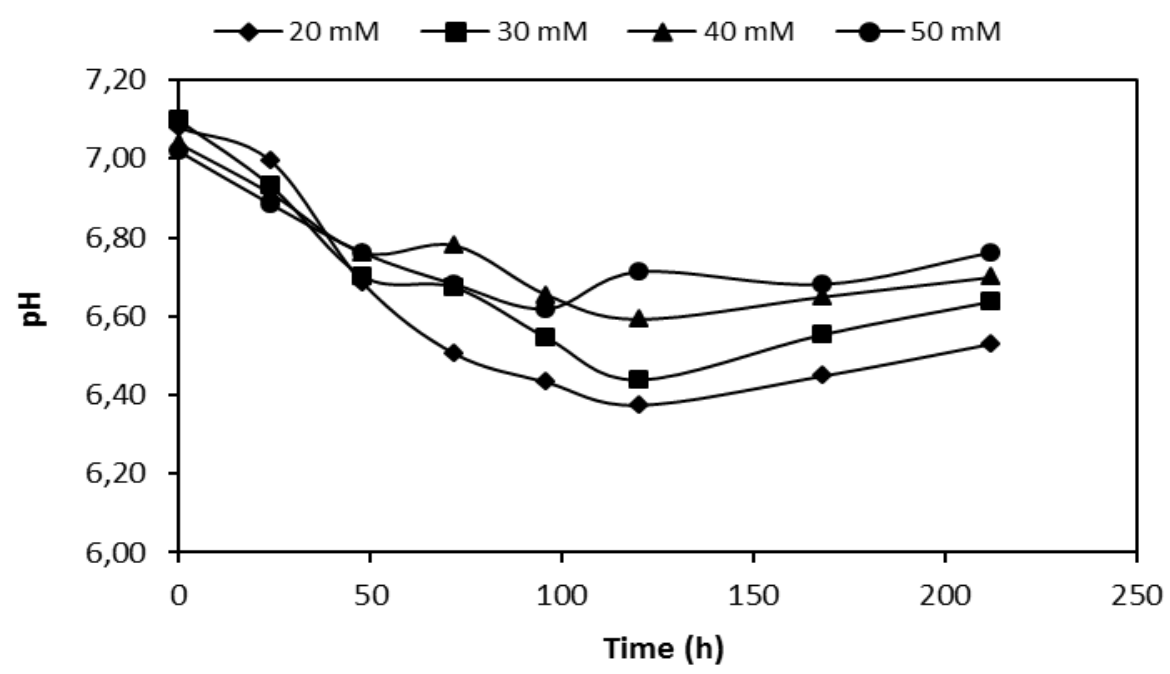

Figure $3.7 \mathrm{pH}$ curves of R.capsulatus YO3 (Hup-) in $5 \mathrm{mM}$ sucrose from molasses which is prepared by different concentrations of $\mathrm{KH}_{2} \mathrm{PO}_{4}$ buffers (initial $\mathrm{pH}$ was 7.0)

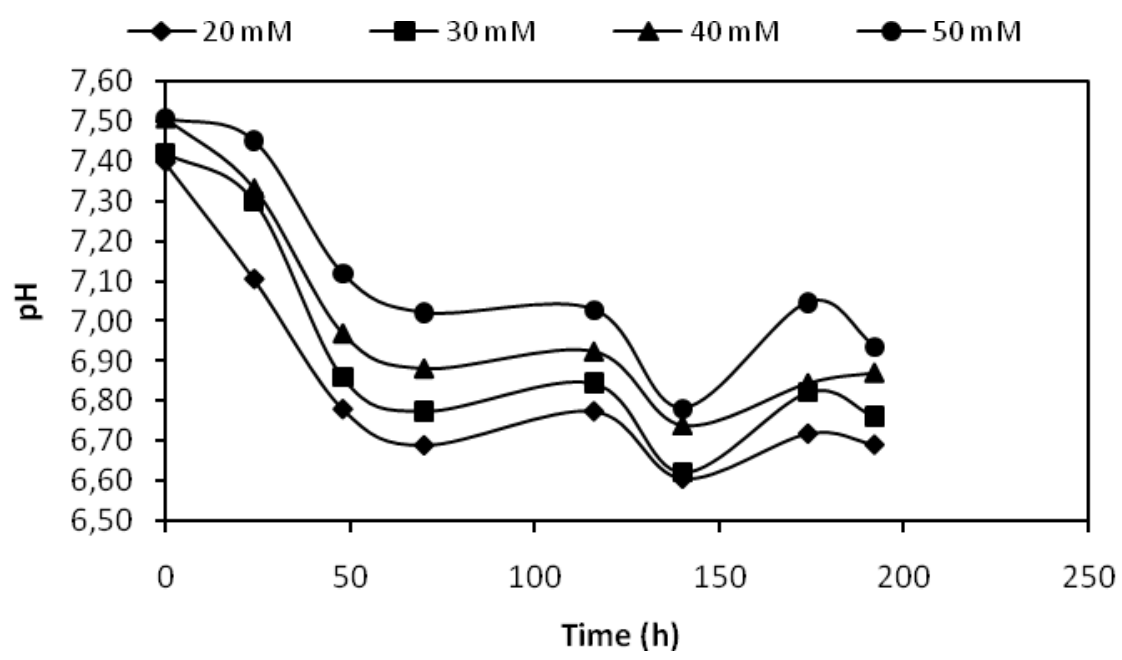

Figure $3.8 \mathrm{pH}$ curves of R.capsulatus YO3 (Hup-) in $5 \mathrm{mM}$ sucrose defined medium which is prepared by different concentrations of $\mathrm{KH}_{2} \mathrm{PO}_{4}$ buffers (initial $\mathrm{pH}$ was 7.5) 
The effect of buffer concentrations were also examined on molasses. Molasses was diluted to have sucrose concentration of $5 \mathrm{mM}$ and various buffer concentrations. The initial $\mathrm{pH}$ was adjusting to 7.5. The variation in $\mathrm{pH}$ during hydrogen production by $R$. capsulatus YO3 and R. capsulatus DSM 1710 are illustrated in Figure 3.8 and 3.9 , respectively.

More rapid decrease in $\mathrm{pH}$ on molasses medium than pure sucrose medium was observed. Initial $\mathrm{pH}$ of 7.5 were more effective than $\mathrm{pH}$ of 7.0 for providing a stable $\mathrm{pH}$ mode in both hydrogen production media. Nath and Das (2009) reported that initial $\mathrm{pH}$ raised up hydrogen production and biomass growth during photofermentation by $R$. sphaeroides and they also stated that optimum initial $\mathrm{pH}$ was 7.0. Increasing buffer concentrations ensured a stable $\mathrm{pH}$ mode at range of below 5.5 to 6.5 .

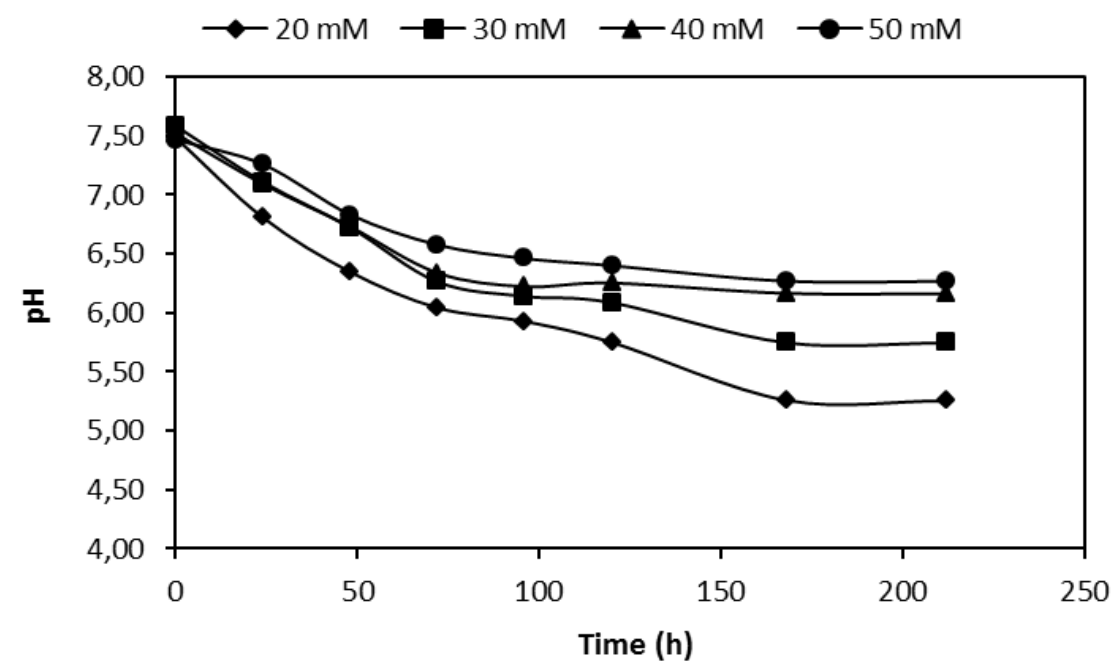

Figure $3.9 \mathrm{pH}$ curves of R.capsulatus YO3 (Hup-) in $5 \mathrm{mM}$ sucrose from molasses which was prepared by different concentrations of $\mathrm{KH}_{2} \mathrm{PO}_{4}$ buffers (initial $\mathrm{pH}$ was 7.5) 


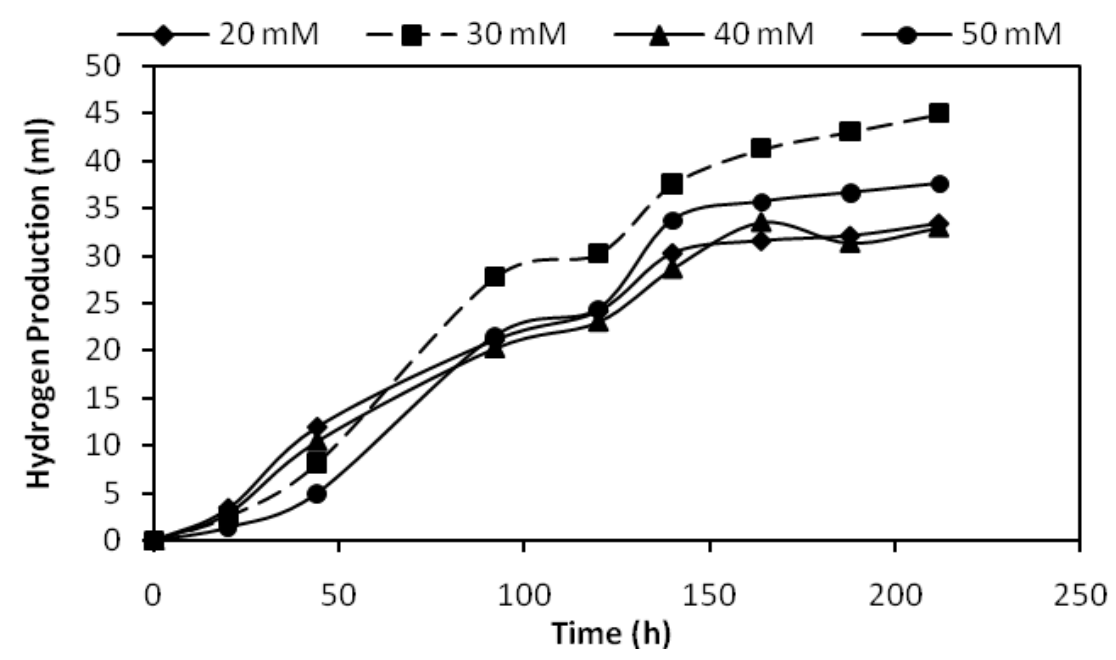

Figure 3.10 The cumulative hydrogen production $(\mathrm{ml})$ at different concentrations of $\mathrm{KH}_{2} \mathrm{PO}_{4}$ buffers on $5 \mathrm{mM}$ sucrose from molasses in $50 \mathrm{ml}$ PBRs.

Hydrogen production ability was more using $30 \mathrm{mM} \mathrm{KH}_{2} \mathrm{PO}_{4}$ buffer than the other concentrations. Figure 3.10 shows the cumulative hydrogen production at different $\mathrm{KH}_{2} \mathrm{PO}_{4}$ buffer concentrations on $5 \mathrm{mM}$ sucrose from molasses.

\subsection{Growth and Hydrogen Production on Sucrose by Different Strains of Purple Non-sulfur (PNS) Bacteria}

Growth and hydrogen production by four different strains of bacteria, $R$. capsulatus YO3 (hup-), R. capsulatus DSM 1710, R. sphaeroides O.U.001 and R. palustris, were studied on three different $(5,7.5$ and 10) sucrose concentrations in $50 \mathrm{ml}$ photobioreactors under 2000-2200 lux illumination at $30-32{ }^{\circ} \mathrm{C}$. Initial $\mathrm{pH}$ was set to 7.2-7.4 and $30 \mathrm{mM} \mathrm{K \textrm {K } _ { 2 }} \mathrm{PO}_{4}$ was used as buffer in all hydrogen production media. 


\subsubsection{Experiments on $R$. capsulatus (DSM 1710)}

The number of bacterial cells showed a dramatic increase at exponential phase after a short lag phase. Most of the hydrogen was generated at time duration of 0-48 hours. The maximum biomass was approximately $0,6 \mathrm{gdcw} / \mathrm{l}_{\mathrm{c}}$ and same for all PBRs. Therefore, sucrose may be considered as a good carbohydrate source for growth. Figure 3.11 is the depiction of biomass growth of $R$. capsulatus (DSM 1710) on different sucrose concentrations.

The products of the hydrogen metabolism of PNS bacteria on sucrose utilization are organic acids such as acetic acid, lactic acid, propionic acid and butyric acid. During the growth and metabolism of sucrose results the production of those intermediates. Due to acidic nature, they are able to lower the $\mathrm{pH}$. The organic acids first produced and then consumed during the hydrogen production process. Shown in Table 3.1 is the initial and final organic acid concentrations during hydrogen production by $R$. capsulatus (DSM 1710) on sucrose.

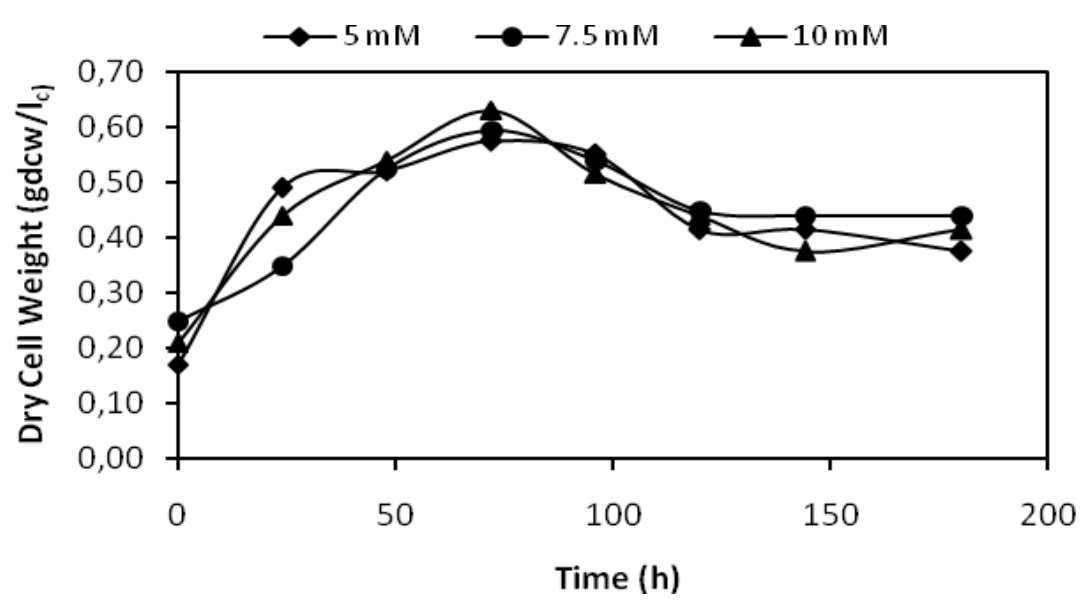

Figure 3.11 The growth of $R$. capsulatus DSM 1710 on $5 \mathrm{mM}, 7.5 \mathrm{mM}$ and $10 \mathrm{mM}$ sucrose hydrogen production media. 
The $\mathrm{pH}$, which was initially set as 7.2-7.3, showed a great decline and it was 6.0-6.5 at the end of 192 hours process. The difference between initial and final $\mathrm{pH}$ of the PBRs was more in increasing start up sucrose concentrations, most probably due to production of more organic acids. This event explains the one of the reasons in $\mathrm{pH}$ drops through the hydrogen production. The change in $\mathrm{pH}$ was given in Figure 3.12.

A proportional link can be inferred between biomass and hydrogen production of bacteria. Both parameters show increments till about 48 hours. However, after 48 hours of the operation, both hydrogen production and growth slowed down.

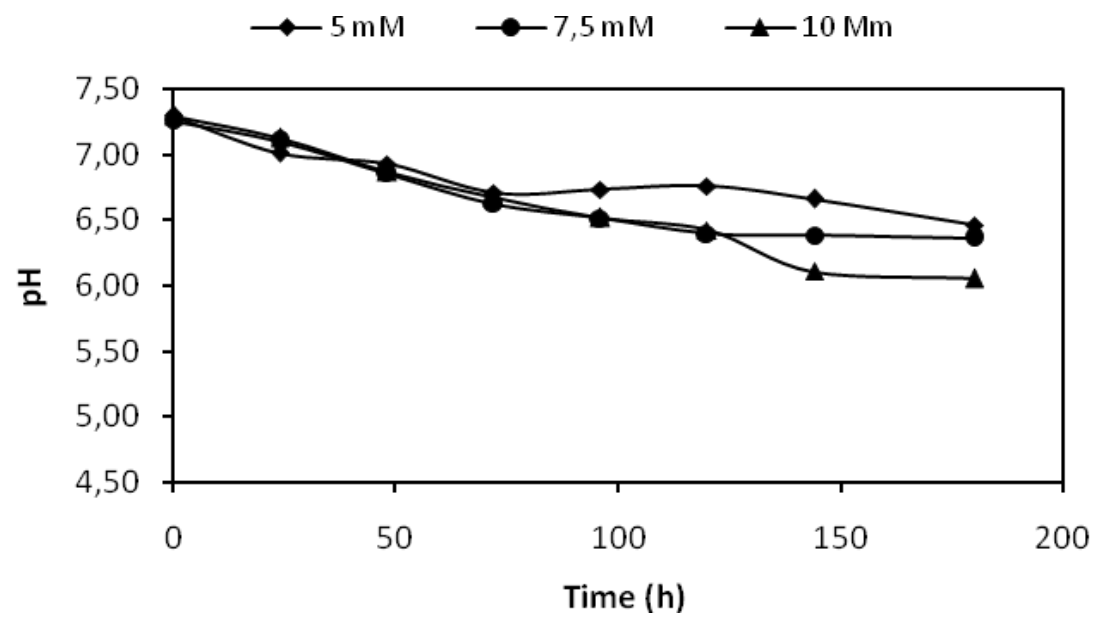

Figure 3.12 The $\mathrm{pH}$ changes of $R$. capsulatus DSM 1710 on $5 \mathrm{mM}, 7.5 \mathrm{mM}$ and 10 $\mathrm{mM}$ sucrose hydrogen production media

The total hydrogen production on $5,7.5$ and $10 \mathrm{mM}$ sucrose media were $0.2,0.86$ and $0.61 / 1_{c}$, respectively. Figure 3.13 shows the cumulative hydrogen production of R.capsulatus DSM 1710 on $5 \mathrm{mM}, 7.5 \mathrm{mM}$ and $10 \mathrm{mM}$ sucrose hydrogen production media. 


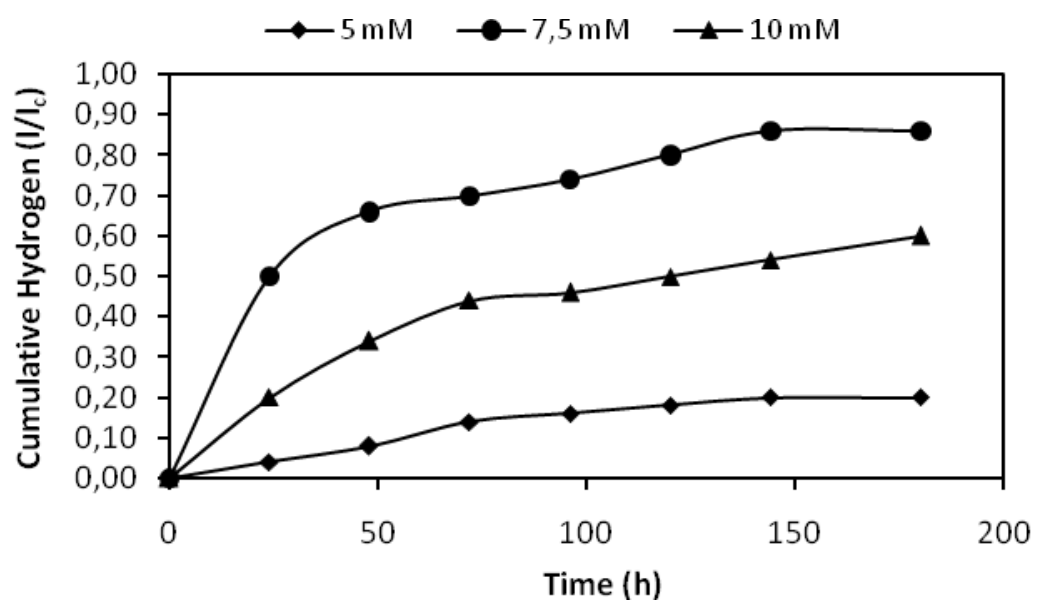

Figure 3.13 The cumulative hydrogen production of $R$. capsulatus DSM 1710 on 5 $\mathrm{mM}, 7.5 \mathrm{mM}$ and $10 \mathrm{mM}$ sucrose hydrogen production media.

Table 3.1 Concentrations of organic acids in photofermentation of R.capsulatus DSM 1710 on $5 \mathrm{mM}, 7.5 \mathrm{mM}$ and $10 \mathrm{mM}$ sucrose hydrogen production media.

\begin{tabular}{|c|c|c|c|c|c|c|}
\hline Hydrogen production media & \multicolumn{2}{|c|}{$5 \mathrm{mM}$ Sucrose } & \multicolumn{2}{c|}{$7.5 \mathrm{mM}$ Sucrose } & \multicolumn{2}{c|}{$10 \mathrm{mM}$ Sucrose } \\
\hline Organic acids & $\mathrm{C}_{0}(\mathrm{mM})$ & $\mathrm{C}_{\mathrm{f}}(\mathrm{mM})$ & $\mathrm{C}_{0}(\mathrm{mM})$ & $\mathrm{C}_{\mathrm{f}}(\mathrm{mM})$ & $\mathrm{C}_{0}(\mathrm{mM})$ & $\mathrm{C}_{\mathrm{f}}(\mathrm{mM})$ \\
\hline Acetic acid & 0.117 & 3.320 & 0.041 & 1.177 & 0.021 & 4.172 \\
\hline Formic acid & 0.643 & 16.403 & 0.392 & 2.569 & 0.265 & 6.113 \\
\hline Lactic acid & 0.43 & 0.08 & 0.23 & 0.99 & 0.04 & 0.00 \\
\hline
\end{tabular}

$\mathrm{C}_{0} *$ The initial concentration $(\mathrm{mM})$

$\mathrm{C}_{\mathrm{f}} *$ The final concentration $(\mathrm{mM})$

Lactic acid is produced and consumed in all the hydrogen production media, whereas acetic acid and formic acid was generally directed in just production rather than consumption after producing them. Figure 3.15 shows the formic acid production on different sucrose media. The production and consumption of organic acids are given 
in Table 3.1. Figure 3.14 indicates organic acid production by R.capsulatus (DSM 1710) on $5 \mathrm{mM}$ sucrose defined medium. Sucrose was consumed by R.capsulatus DSM 1710 as $\% 100, \% 71$ and $\% 50$ in $5 \mathrm{mM}, 7.5 \mathrm{mM}$ and $10 \mathrm{mM}$ sucrose containing PBRs, respectively. Given in Table 3.2 and Figure 3.16 is the consumption of sucrose by R.capsulatus (DSM 1710) on different sucrose media.

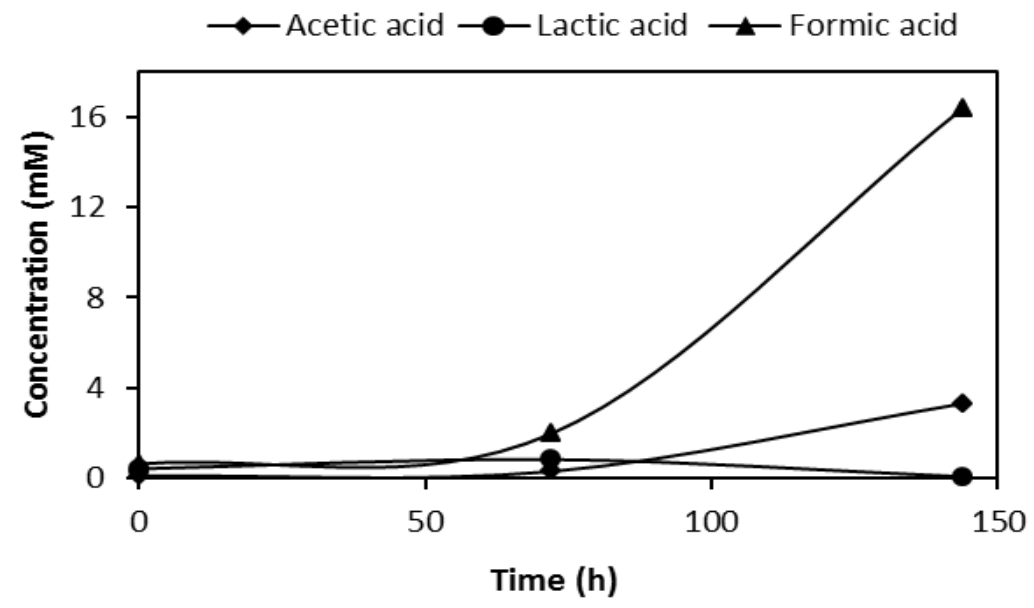

Figure 3.14 Organic acid production by $R$. capsulatus (DSM 1710) on $5 \mathrm{mM}$ sucrose defined medium.

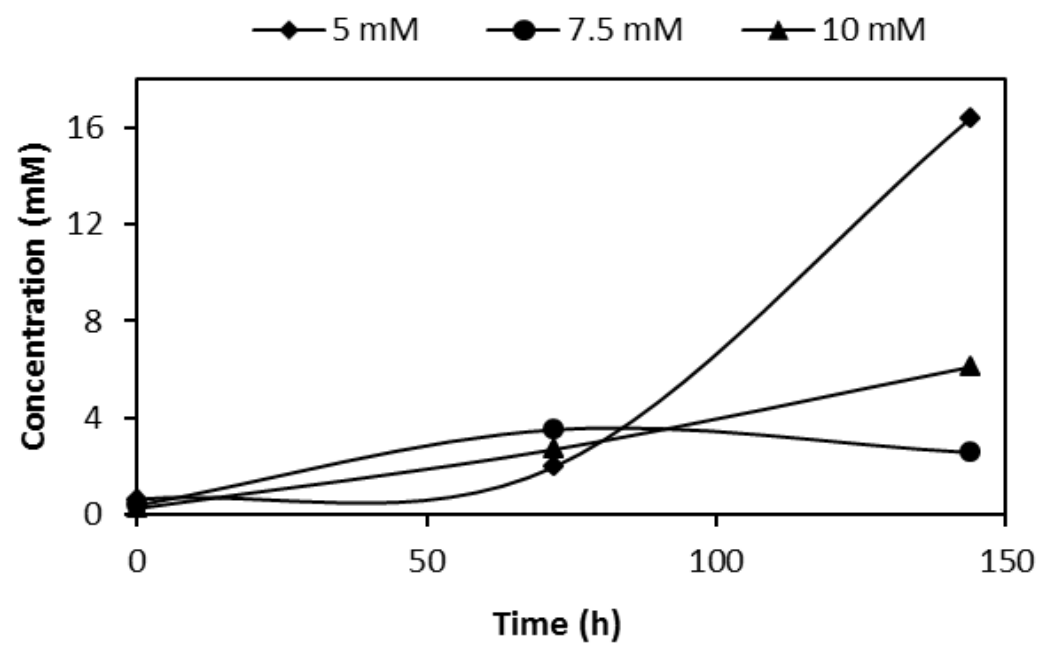

Figure 3.15 Formic acid production by $R$. capsulatus DSM 1710 on different sucrose concentrations. 


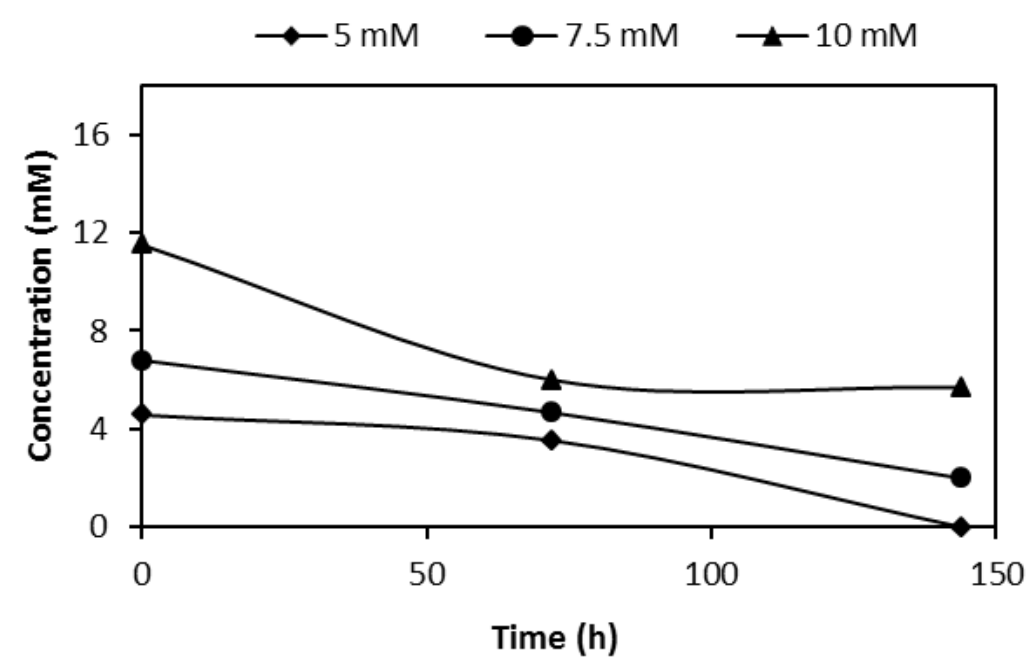

Figure 3.16 Sucrose consumption by $R$. capsulatus DSM 1710 on $5 \mathrm{mM}, 7.5 \mathrm{mM}$ and $10 \mathrm{mM}$ sucrose hydrogen production media.

Table 3.2 The utilization of sucrose by R.capsulatus (DSM 1710) on $5 \mathrm{mM}, 7.5 \mathrm{mM}$ and $10 \mathrm{mM}$ sucrose hydrogen production media.

\begin{tabular}{|c|c|c|c|}
\hline $\begin{array}{c}\text { Sucrose concentrations } \\
\text { (PBRs) }\end{array}$ & $\mathrm{C}_{0}(\mathrm{mM})$ & $\mathrm{C}_{\mathrm{f}}(\mathrm{mM})$ & Sucrose consumption (\%) \\
\hline $5 \mathrm{mM}$ & 4.57 & 0 & 100 \\
\hline $7.5 \mathrm{mM}$ & 6.80 & 1.99 & 71 \\
\hline $10 \mathrm{mM}$ & 11.5 & 5.7 & 50.4 \\
\hline
\end{tabular}




\subsubsection{Experiments on $R$. capsulatus YO3 (Hup")}

The growth curves of $R$. capsulatus YO3 (Hup ${ }^{-}$) showed that bacteria increase cell populations from $0.15 \mathrm{gdcw} / \mathrm{l}_{\mathrm{c}}$ to $0.4 \mathrm{gdcw} / \mathrm{l}_{\mathrm{c}}$ between $0-48$ time period. After that, steady state was observed. The cells in media of $10 \mathrm{mM}$ sucrose grow faster and had maximum biomass of $0.62 \mathrm{gdcw} / \mathrm{l}_{\mathrm{c}}$.

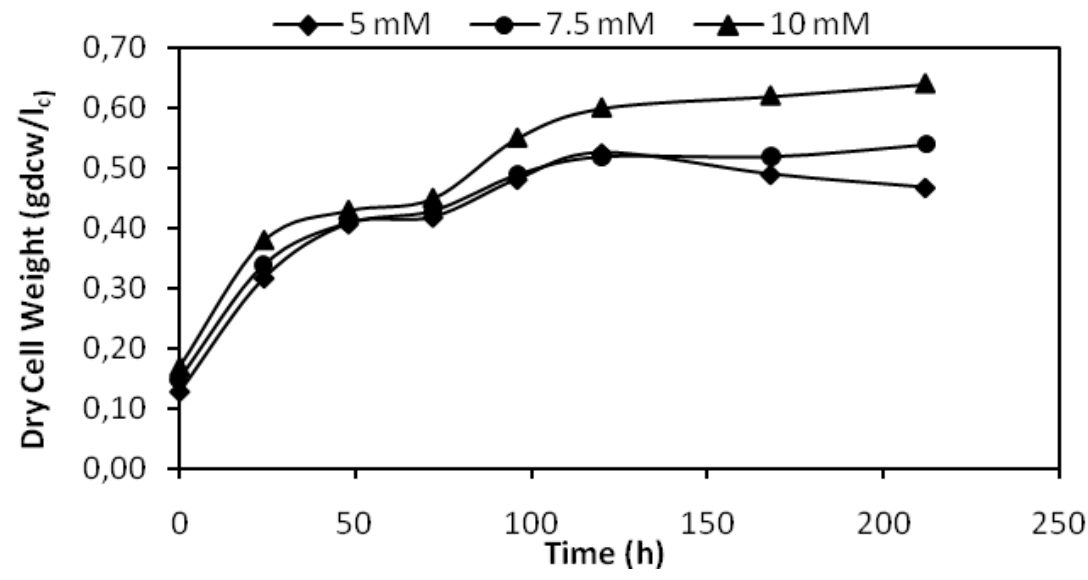

Figure 3.17 The growth of $R$. capsulatus YO3 (Hup-) on $5 \mathrm{mM}, 7.5 \mathrm{mM}$ and $10 \mathrm{mM}$ sucrose hydrogen production media.

The $\mathrm{pH}$ dramatically declined from initial value of 7.2-7.4 to about 5.8-6.0 levels in all the three PBRs. Figure shows the organic acids production in the PBRs. The growth and $\mathrm{pH}$ changes of R.capsulatus $\mathrm{YO}$ (Hup ${ }^{-}$) were given in Figure 3.17 and 3.18 respectively. 


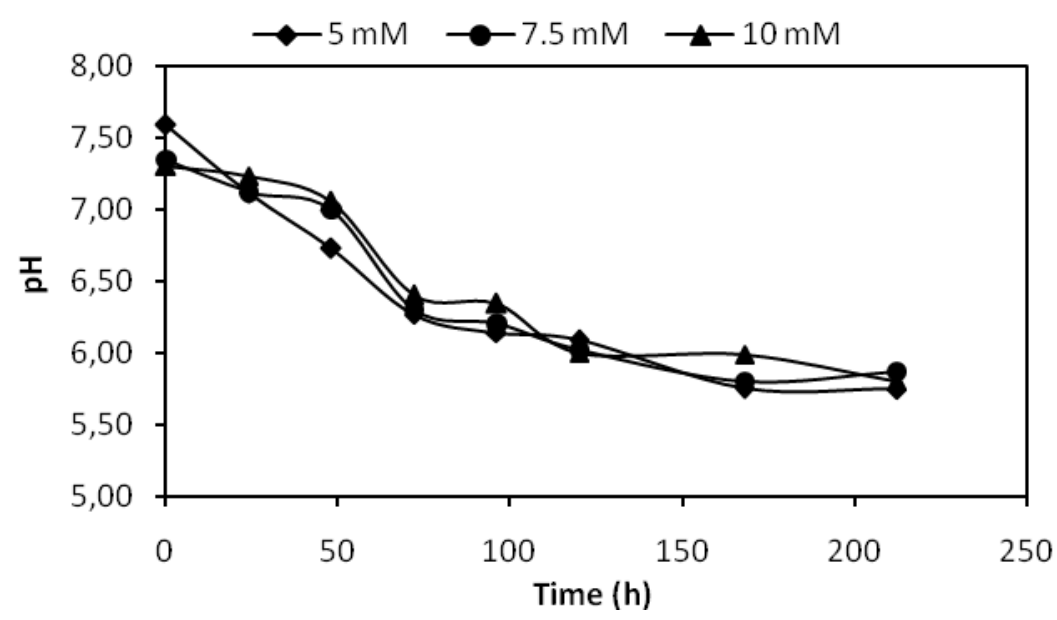

Figure 3.18 The mode of $\mathrm{pH}$ of $R$. capsulatus YO3 (Hup-) on $5 \mathrm{mM}, 7.5 \mathrm{mM}$ and 10 $\mathrm{mM}$ sucrose hydrogen production media.

The cumulative hydrogen production was higher on $5 \mathrm{mM}$ sucrose PBR than the others. On the contrary, the hydrogen production showed a fluctuated profile during 230 hours for the same PBR and the maximum hydrogen production was $0.81 / 1_{c}$. It was observed near two times more hydrogen was generated in $5 \mathrm{mM}$ sucrose than 7.5 and $10 \mathrm{mM}$ sucrose containing PBRs. The cumulative hydrogen production was given in Figure 3.19.

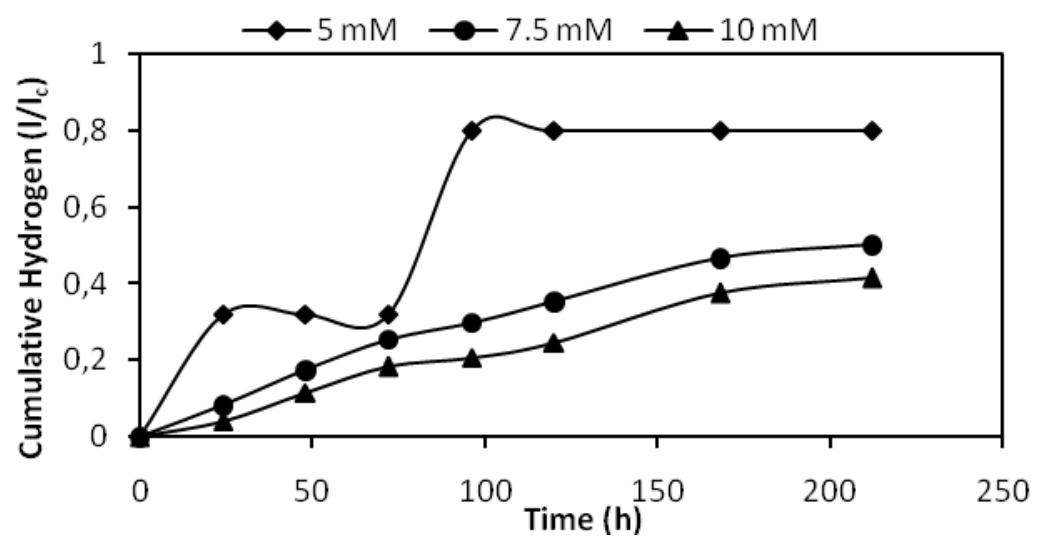

Figure 3.19 The cumulative hydrogen production (1/lc) of $R$. capsulatus YO3 (Hup-) on $5 \mathrm{mM}, 7.5 \mathrm{mM}$ and $10 \mathrm{mM}$ sucrose hydrogen production media. 
Acetic acid and formic acid were produced and not consumed during 216 hours operation time. Lactic acid was produced and used by the bacteria. The organic acid products were formed by the action of the bacteria on sucrose through hydrogen production. Figure 3.20 shows organic acid production on $5 \mathrm{mM}$ sucrose.

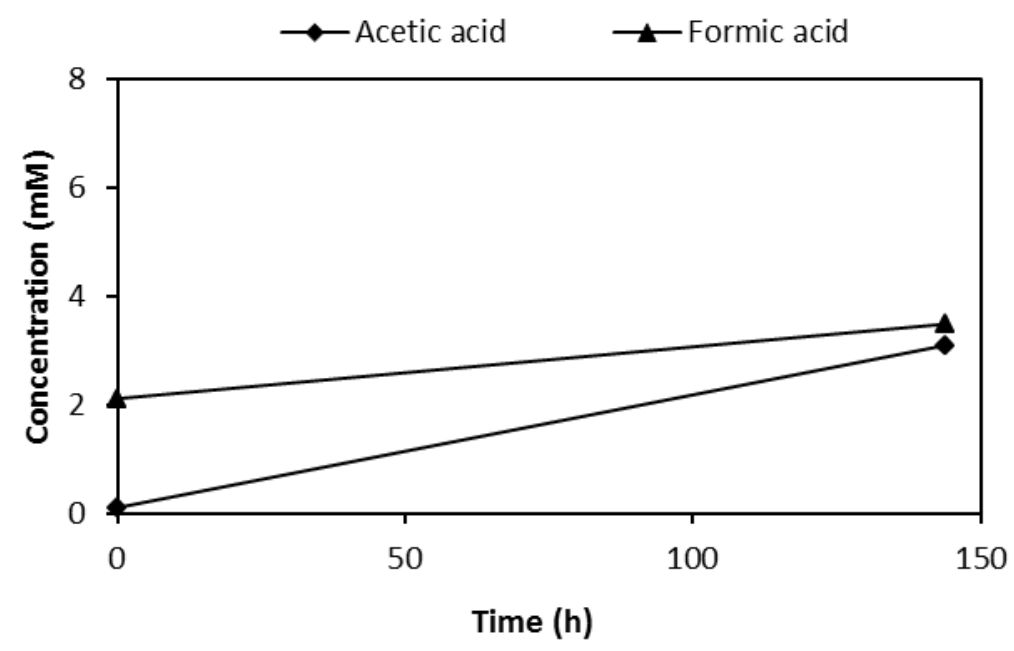

Figure 3.20 Acetic acid and formic acid production on $5 \mathrm{mM}$ sucrose by $R$. capsulatus YO3 (Hup`).

Main organic acids was acetic acid and formic acid in all of the hydrogen media. These compounds were directed into just production rather than consumption. Therefore, acidity of the media were increased and hydrogen production was adversely affected. 
Table 3.3 Concentrations of organic acids in photofermentation of R.capsulatus YO3 (Hup) on $5 \mathrm{mM}, 7.5 \mathrm{mM}$ and $10 \mathrm{mM}$ sucrose hydrogen production media. Glutamate $(2 \mathrm{mM})$ was used as the nitrogen source.

\begin{tabular}{|c|c|c|c|c|c|c|}
\hline Hydrogen production media & \multicolumn{2}{|c|}{$5 \mathrm{mM}$ Sucrose } & \multicolumn{2}{c|}{$7.5 \mathrm{mM}$ Sucrose } & \multicolumn{2}{c|}{$10 \mathrm{mM}$ Sucrose } \\
\hline Organic acids & $\mathrm{C}_{0}(\mathrm{mM})$ & $\mathrm{C}_{\mathrm{f}}(\mathrm{mM})$ & $\mathrm{C}_{0}(\mathrm{mM})$ & $\mathrm{C}_{\mathrm{f}}(\mathrm{mM})$ & $\mathrm{C}_{0}(\mathrm{mM})$ & $\mathrm{C}_{\mathrm{f}}(\mathrm{mM})$ \\
\hline Acetic acid & 0.112 & 3.098 & 0.32 & 4.54 & 0.23 & 5.65 \\
\hline Formic acid & 2.117 & 3.488 & 3.12 & 4.32 & 3.45 & 5.32 \\
\hline Lactic acid & 0 & 0 & 0.2 & 0 & 0.12 & 0.08 \\
\hline
\end{tabular}

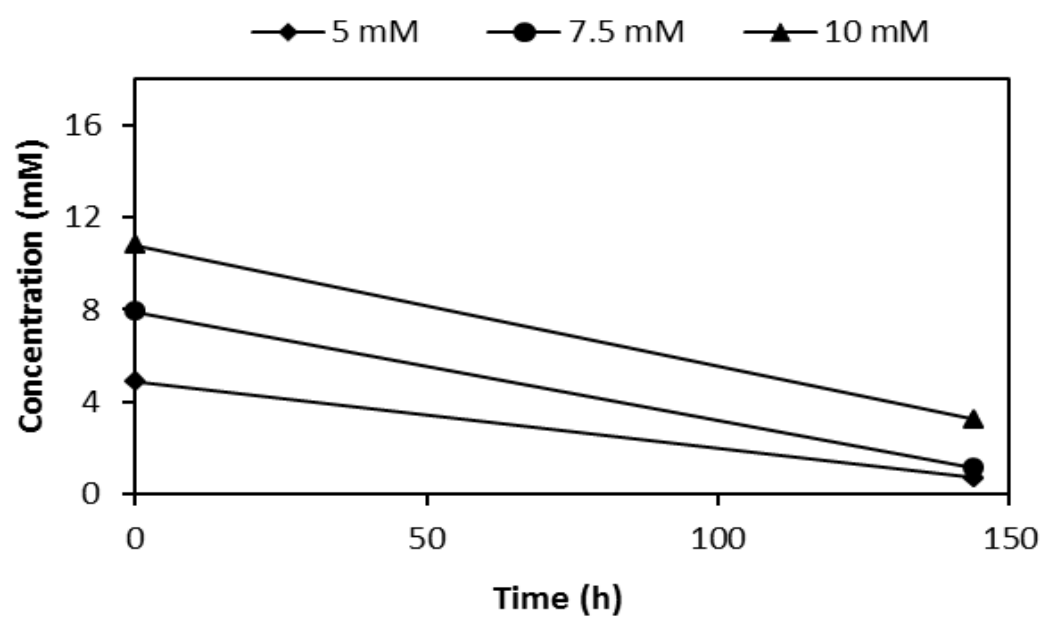

Figure 3.21 The consumption curves of $R$. capsulatus YO3 (Hup-) on different sucrose concentrations.

The consumption (\%) of sucrose was $85,85.5$ and 70 in 5, 7.5 and $10 \mathrm{mM}$ sucrose containing PBRs, respectively. Figure 3.21 and Table 3.4 indicate utilization of different sucrose concentrations by R.capsulatus YO3 (Hup'). 
Table 3.4 The utilization of sucrose by R.capsulatus YO3 (Hup ${ }^{-}$) on $5 \mathrm{mM}, 7.5 \mathrm{mM}$ and $10 \mathrm{mM}$ sucrose hydrogen production media.

\begin{tabular}{|c|c|c|c|}
\hline $\begin{array}{c}\text { Sucrose concentrations } \\
\text { (PBRs) }\end{array}$ & $\mathrm{C}_{0}(\mathrm{mM})$ & $\mathrm{C}_{\mathrm{f}}(\mathrm{mM})$ & Sucrose consumption (\%) \\
\hline $5 \mathrm{mM}$ & 4.88 & 0.73 & 85 \\
\hline $7.5 \mathrm{mM}$ & 7.89 & 1.14 & 85.5 \\
\hline $10 \mathrm{mM}$ & 10.78 & 3.25 & 70.0 \\
\hline
\end{tabular}

\subsubsection{Experiments on $R$. palustris (DSM 127)}

$R R$. palustris (DSM 127) was used for hydrogen production on different sucrose defined media at $5 \mathrm{mM}, 7.5$ and $10 \mathrm{mM}$ concentration in $50 \mathrm{ml}$ bioreactors. The $\mathrm{pH}$ changes, growth and hydrogen production were followed during 200 hours batch process. The $\mathrm{pH}$ was stabilized at 6.7 level after a rapid decrease from the initial $\mathrm{pH}$ of 7.4 in $5 \mathrm{mM}$ sucrose containing PBR. On the contrary, $\mathrm{pH}$ was declined and reached to about 6.5 level in 7.5 and $10 \mathrm{mM}$ sucrose PBRs (Figure 3.16).

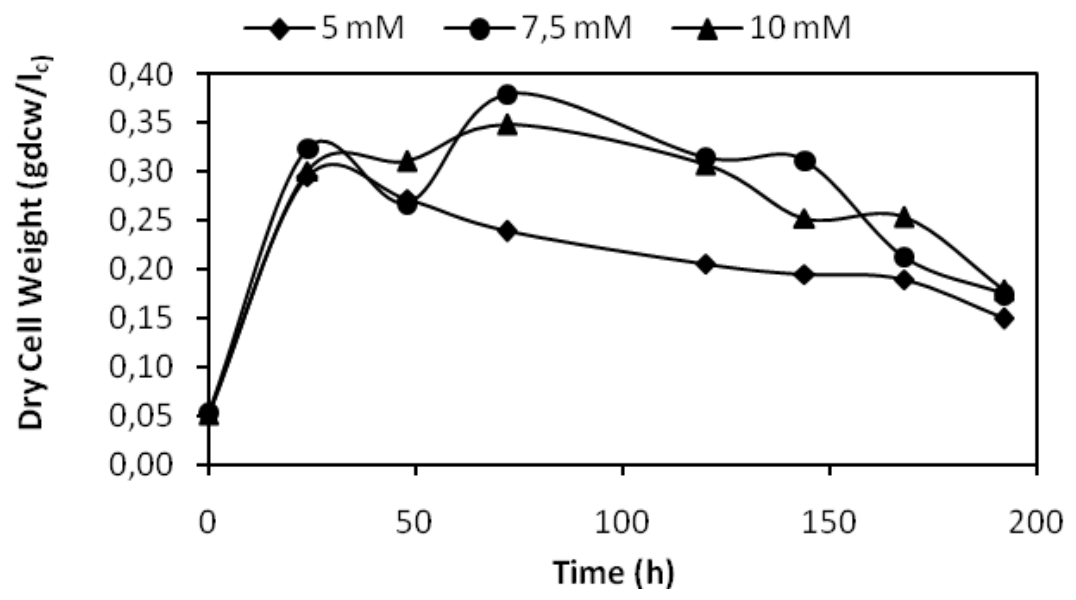

Figure 3.15 The growth of $R$. palustris (DSM 127) on $5 \mathrm{mM}, 7.5 \mathrm{mM}$ and $10 \mathrm{mM}$ sucrose hydrogen production media. 
Figure 3.15 illustrates the growth profile. A rapid growth was observed during the frst $24 \mathrm{~h}$ of operation. The cell growth was more on $7.5 \mathrm{mM}$ and $10 \mathrm{mM}$ sucrose concentrations, while at $5 \mathrm{mM}$ a decline in biomass concentration was observed after $24 \mathrm{~h}$.

Hydrogen production was higher with $5 \mathrm{mM}$ sucrose and $7.5 \mathrm{mM}$ as $1.41 / l_{\mathrm{c}}$ and 1.5 $1 / 1_{c}$ during 200 hours operation. The maximum biomass and hydrogen production was observed on $7.5 \mathrm{mM}$ sucrose containing PBR. Figure 3.17 shows the cumulative hydrogen production of $R$. palustris (DSM 127).

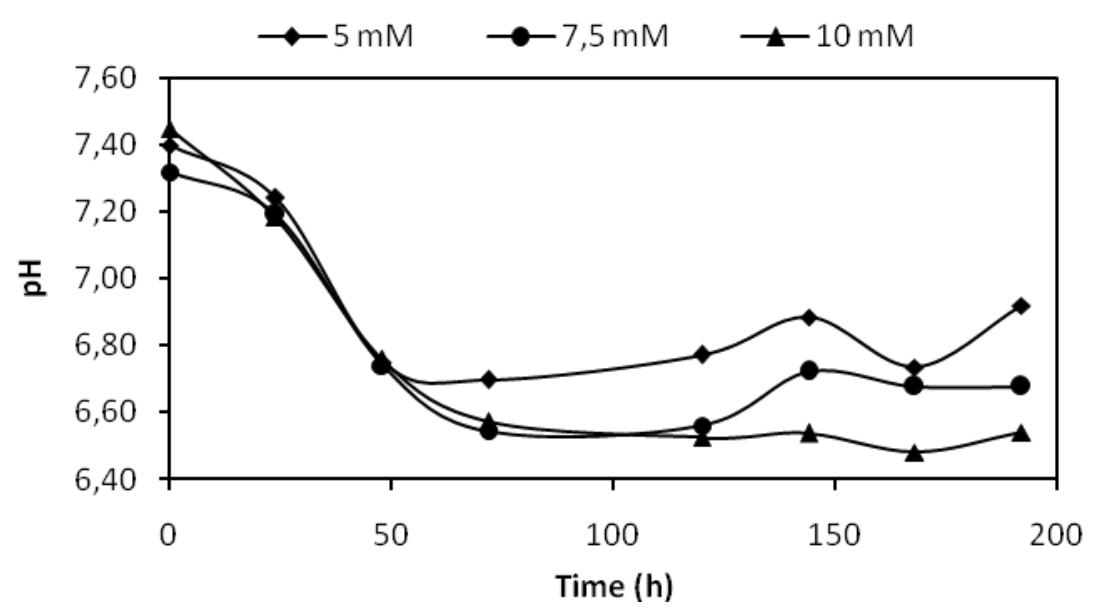

Figure 3.16 The pH changes of $R$. palustris (DSM127) on $5 \mathrm{mM}, 7.5 \mathrm{mM}$ and 10 $\mathrm{mM}$ sucrose hydrogen production media. 


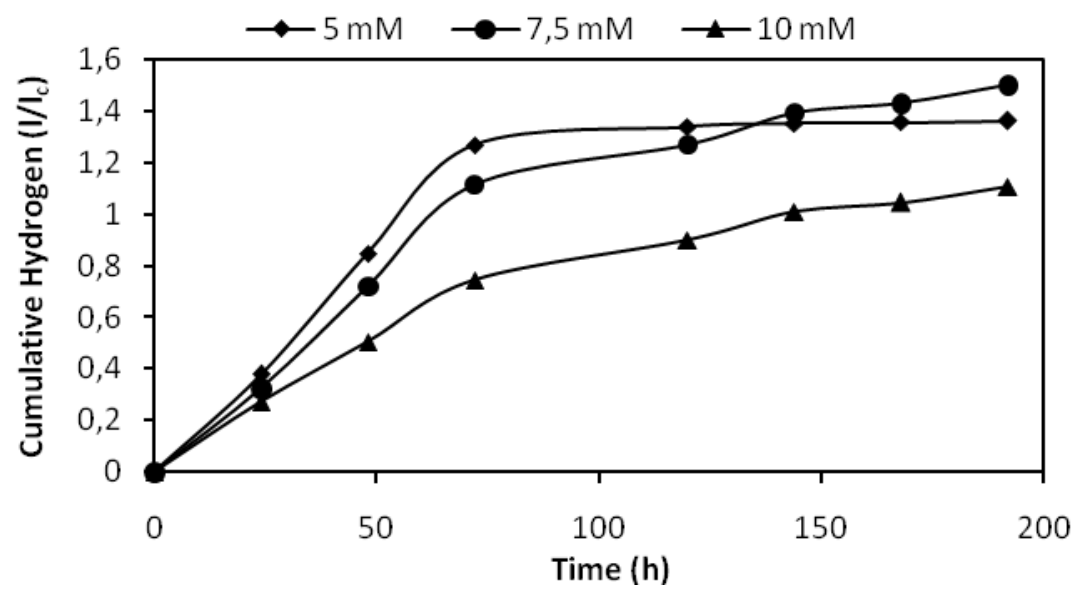

Figure 3.17 The cumulative hydrogen production of $R$. palustris (DSM127) on 5 $\mathrm{mM}, 7.5 \mathrm{mM}$ and $10 \mathrm{mM}$ sucrose hydrogen production media.

A rapid increase in production of acetic and formic acids was observed at $72^{\text {th }}$ hours in both $7.5 \mathrm{mM}$ and $10 \mathrm{mM}$ sucrose PBRs. On the contrary, a decline in production of acetic, lactic and formic acids were recorded in $5 \mathrm{mM}$ PBR. Moreover, the acetic and lactic acids were produced and then consumed in $5 \mathrm{mM}$ PBR. The pHs of hydrogen media were also at lower levels due to high organic acid amounts in the PBRs. Table 3.5 summarizes initial and final concentrations of the organic acid products.

Table 3.5 Concentrations of organic acids in photofermentation of $R$. palustris (DSM127) on $5 \mathrm{mM}, 7.5 \mathrm{mM}$ and $10 \mathrm{mM}$ sucrose hydrogen production media.

\begin{tabular}{|c|c|c|c|c|c|c|}
\hline Hydrogen production media & \multicolumn{2}{|c|}{$5 \mathrm{mM}$ Sucrose } & \multicolumn{2}{c|}{$7.5 \mathrm{mM}$ Sucrose } & \multicolumn{2}{c|}{$10 \mathrm{mM}$ Sucrose } \\
\hline Organic acids & $\mathrm{C}_{0}(\mathrm{mM})$ & $\mathrm{C}_{\mathrm{f}}(\mathrm{mM})$ & $\mathrm{C}_{0}(\mathrm{mM})$ & $\mathrm{C}_{\mathrm{f}}(\mathrm{mM})$ & $\mathrm{C}_{0}(\mathrm{mM})$ & $\mathrm{C}_{\mathrm{f}}(\mathrm{mM})$ \\
\hline Acetic acid & 0.074 & 0 & 0.088 & 0 & 0.213 & 19.15 \\
\hline Formic acid & 0.420 & 3.056 & 0.429 & 10.46 & 0.579 & 5.76 \\
\hline Lactic acid & 0.15 & 0 & 0.14 & 0 & 0.19 & 0 \\
\hline
\end{tabular}


Sucrose utilization by $R$. palustris (DSM127) on $5 \mathrm{mM}, 7.5 \mathrm{mM}$ and $10 \mathrm{mM}$ sucrose hydrogen production media was quite high, compared to other PNS bacterial strains, tested. The sucrose consumption (\%) in PBRs is given in Table 3.6.

Table 3.6 The utilization of sucrose by $R$. palustris (DSM127) on $5 \mathrm{mM}, 7.5 \mathrm{mM}$ and $10 \mathrm{mM}$ sucrose hydrogen production media.

\begin{tabular}{|c|c|c|c|}
\hline $\begin{array}{c}\text { Sucrose concentrations } \\
(\text { PBRs })\end{array}$ & $\mathrm{C}_{0}(\mathrm{mM})$ & $\mathrm{C}_{\mathrm{f}}(\mathrm{mM})$ & Sucrose consumption (\%) \\
\hline $5 \mathrm{mM}$ & 4.94 & 0.19 & 96.1 \\
\hline $7.5 \mathrm{mM}$ & 7.99 & 1.51 & 81.1 \\
\hline $10 \mathrm{mM}$ & 9.54 & 1.06 & 88.9 \\
\hline
\end{tabular}

\subsubsection{Experiments on $R$. sphaeroides O.U.001 (DSM 5864)}

In this part, $R$. sphaeroides O.U.001 (DSM 5864) was investigated for biohydrogen production by sucrose. A 180 hours operation was done using $50 \mathrm{ml}$ bioreactors. The biomass growth indicated that $R$. sphaeroides O.U.001 (DSM 5864) grows well on sucrose. Figure 3.18 shows the growth of the bacteria.

$\mathrm{pH}$ variation during hydrogen production were the same range in all the PBRs. All of the final $\mathrm{pHs}$ were in the range $6.5-7.0$ and began to drop after $48^{\text {th }}$ hours by the effect of side products in the media especially acidic compounds. Figure 3.19 is given as the changes of $\mathrm{pHs}$ in the PBRs. 


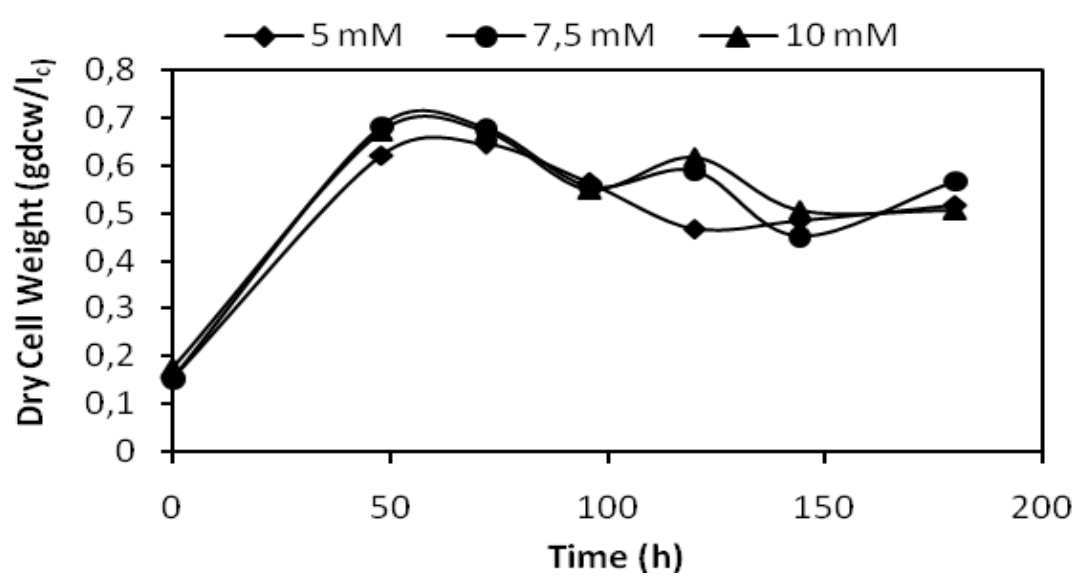

Figure 3.18 The growth of $R$. sphaeroides O.U.001 (DSM 5864) on $5 \mathrm{mM}, 7.5 \mathrm{mM}$ and $10 \mathrm{mM}$ sucrose containing hydrogen production media.

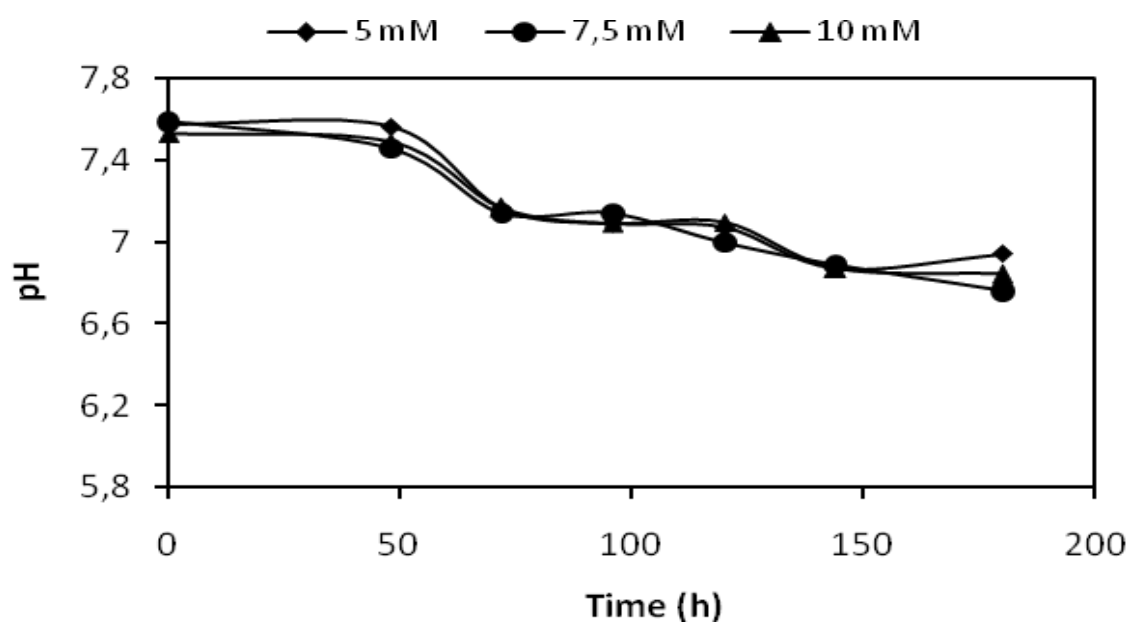

Figure 3.19 The pH changes of $R$. sphaeroides O.U.001 (DSM 5864) on $5 \mathrm{mM}, 7.5$ $\mathrm{mM}$ and $10 \mathrm{mM}$ containing sucrose hydrogen production media.

The maximum hydrogen was produced by $5 \mathrm{mM}$ sucrose medium as $0.861 / \mathrm{l}_{\mathrm{c}}$. The other two PBRs (7.5 mM and $10 \mathrm{mM}$ ) produced $0.601 / 1_{\mathrm{c}}$ and $0.741 / 1_{\mathrm{c}}$. Hydrogen production was continued exponentially till $96^{\text {th }}$ hours. Figure 3.20 is given as the cumulative hydrogen production by $R$. sphaeroides O.U.001 (DSM 5864) on $5 \mathrm{mM}$, $7.5 \mathrm{mM}$ and $10 \mathrm{mM}$ sucrose hydrogen production media. 


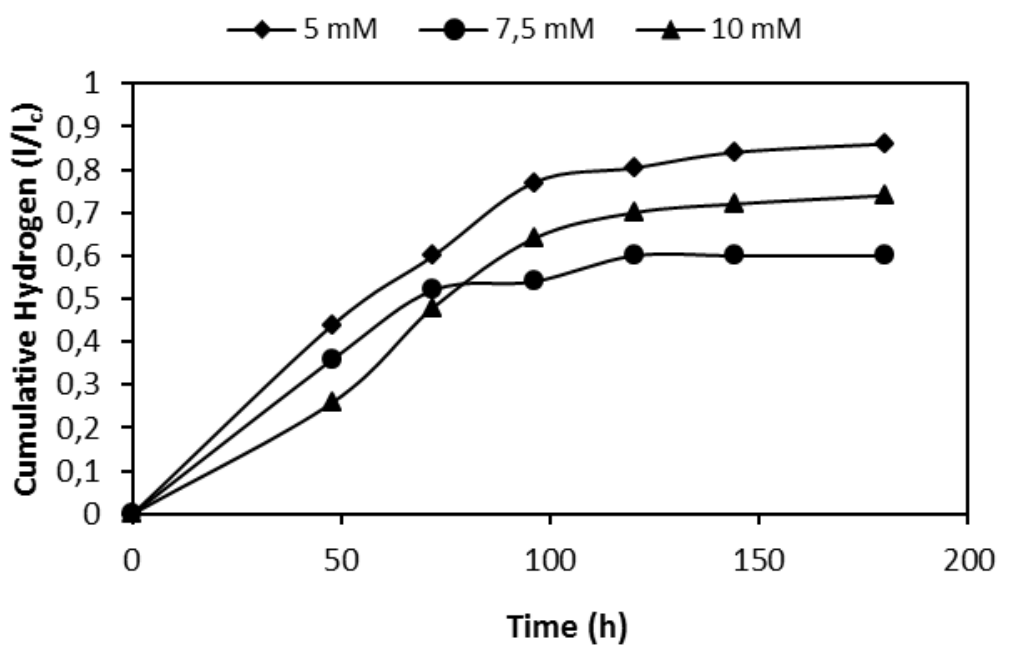

Figure 3.20 The cumulative hydrogen production of $R$. sphaeroides O.U.001 (DSM 5864 ) on $5 \mathrm{mM}, 7.5 \mathrm{mM}$ and $10 \mathrm{mM}$ sucrose containing hydrogen production media.

Formic acid and lactic acid were detected at small amounts whereas acetic acid was not found in the fermentation media of the all PBRs. Acetic acid may be produced and utilized in a short time or its production did not occur. The produced organic acids were shown in Table 3.7. Sucrose conversion of $5 \mathrm{mM}$ PBR was the highest (78.6) and when compared with the other two PBRs. Table 3.8 shows the sucrose conversion by R. sphaeroides O.U.001 (DSM 5864) in three different sucrose media.

Table 3.7 Concentrations of organic acids in photofermentation of $R$. sphaeroides O.U.001 (DSM 5864) on $5 \mathrm{mM}, 7.5 \mathrm{mM}$ and $10 \mathrm{mM}$ sucrose hydrogen production media.

\begin{tabular}{|c|c|c|c|c|c|c|}
\hline Hydrogen production media & \multicolumn{2}{|c|}{$5 \mathrm{mM}$ Sucrose } & \multicolumn{2}{c|}{$7.5 \mathrm{mM}$ Sucrose } & \multicolumn{2}{c|}{$10 \mathrm{mM}$ Sucrose } \\
\hline Organic acids & $\mathrm{C}_{0}(\mathrm{mM})$ & $\mathrm{C}_{\mathrm{f}}(\mathrm{mM})$ & $\mathrm{C}_{0}(\mathrm{mM})$ & $\mathrm{C}_{\mathrm{f}}(\mathrm{mM})$ & $\mathrm{C}_{0}(\mathrm{mM})$ & $\mathrm{C}_{\mathrm{f}}(\mathrm{mM})$ \\
\hline Acetic acid & 0 & 0 & 0 & 0 & 0 & 0 \\
\hline Formic acid & 0.101 & 0.683 & 0 & 1.07 & 0.016 & 1.299 \\
\hline Lactic acid & 0.04 & 0.1 & 0 & 0.06 & 0.05 & 0.07 \\
\hline
\end{tabular}


Table 3.8 The utilization of sucrose by $R$. sphaeroides O.U.001 (DSM 5864) on 5 $\mathrm{mM}, 7.5 \mathrm{mM}$ and $10 \mathrm{mM}$ sucrose hydrogen production media.

\begin{tabular}{|c|c|c|c|}
\hline $\begin{array}{c}\text { Sucrose concentrations } \\
\text { (PBRs) }\end{array}$ & $\mathrm{C}_{0}(\mathrm{mM})$ & $\mathrm{C}_{\mathrm{f}}(\mathrm{mM})$ & Sucrose consumption (\%) \\
\hline $5 \mathrm{mM}$ & 4.88 & 1.04 & 78.6 \\
\hline $7.5 \mathrm{mM}$ & 7.45 & 4.50 & 40.0 \\
\hline $10 \mathrm{mM}$ & 9.89 & 4.59 & 53.5 \\
\hline
\end{tabular}

\subsection{Growth and Hydrogen Production on Molasses by Different Strains of Purple Non-sulfur (PNS) Bacteria}

The objective of this part of the experiments is to investigate the utilization of sucrose from molasses. This part of the study also intends to see the growth and hydrogen production on different sucrose concentrations which was prepared by the dilutions of molasses. Dilution factors were illustrated in section 2 and in Table 2.1. Four different PNS bacteria were used for hydrogen production on three different (5, 7.5 and 10) sucrose concentrations in $50 \mathrm{ml}$ photobioreactors under 2000-2200 lux illumination. Initial $\mathrm{pH}$ was adjusted to 7.2-7.4 and $30 \mathrm{mM} \mathrm{KH}{ }_{2} \mathrm{PO}_{4}$ buffer was used to keep the $\mathrm{pH}$ stable in all hydrogen production media. Vitamins, trace elements and iron-citrate were added to the media.

\subsubsection{Experiments on $R$. capsulatus (DSM 1710)}

There was found an inverse proportion between the growth and concentration of sucrose. Bacterial growth was greater in $5 \mathrm{mM}$ sucrose medium than the others and reached the maximum biomass in 96 hours. Then a steady growth phase has started. The maximum biomass was recorded as $0.6 \mathrm{gdcw} / \mathrm{l}_{\mathrm{c}}, 0.3 \mathrm{gdcw} / \mathrm{l}_{\mathrm{c}}$ and $0.2 \mathrm{gdcw} / \mathrm{l}_{\mathrm{c}}$ for 
in order of $5 \mathrm{mM}, 7.5 \mathrm{mM}$ and $10 \mathrm{mM}$ sucrose from molasses. The growth of $R$. capsulatus (DSM 1710) was given in Figure 3.21.

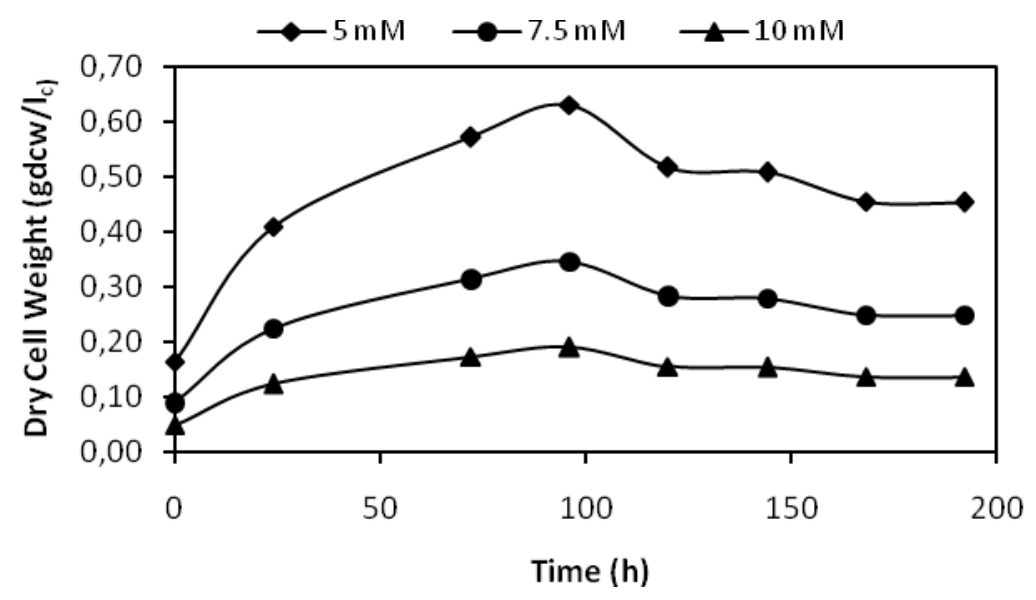

Figure 3.21 The growth of $R$. capsulatus (DSM 1710) in different sucrose concentrations $(5,7.5$ and $10 \mathrm{mM})$ by dilutions of molasses.

A continuous decline in $\mathrm{pH}$ was observed during 0-48 hours time interval. The final $\mathrm{pHs}$ of the bioreactors were in the range of 5.5-5.8. The $\mathrm{pH}$ curves indicated nearly the same manner in all PBRs of $R$. capsulatus (DSM 1710). The $\mathrm{pH}$ variations were given in Figure 3.22. Although the biomass growth was not higher than the other PBRs, hydrogen production was the highest. The cumulative hydrogen production of $5 \mathrm{mM}, 7.5 \mathrm{mM}$ and $10 \mathrm{mM}$ PBRs were found as $0.261 / l_{c}, 0.201 / l_{\mathrm{c}}$ and $0.51 / l_{\mathrm{c}}$ respectively. Figure 3.23 is hydrogen production curves by $R$. capsulatus (DSM 1710) on molasses media with different sucrose concentrations. 


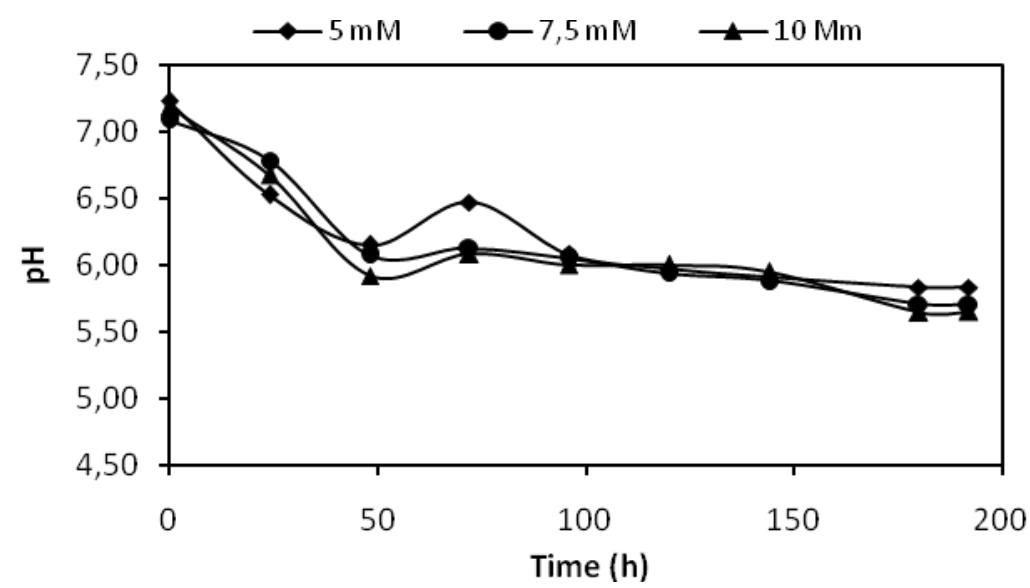

Figure $3.22 \mathrm{pH}$ variation during hydrogen production by $R$. capsulatus (DSM 1710) on different molasses media with different sucrose concentrations (5, 7.5 and 10 $\mathrm{mM})$.

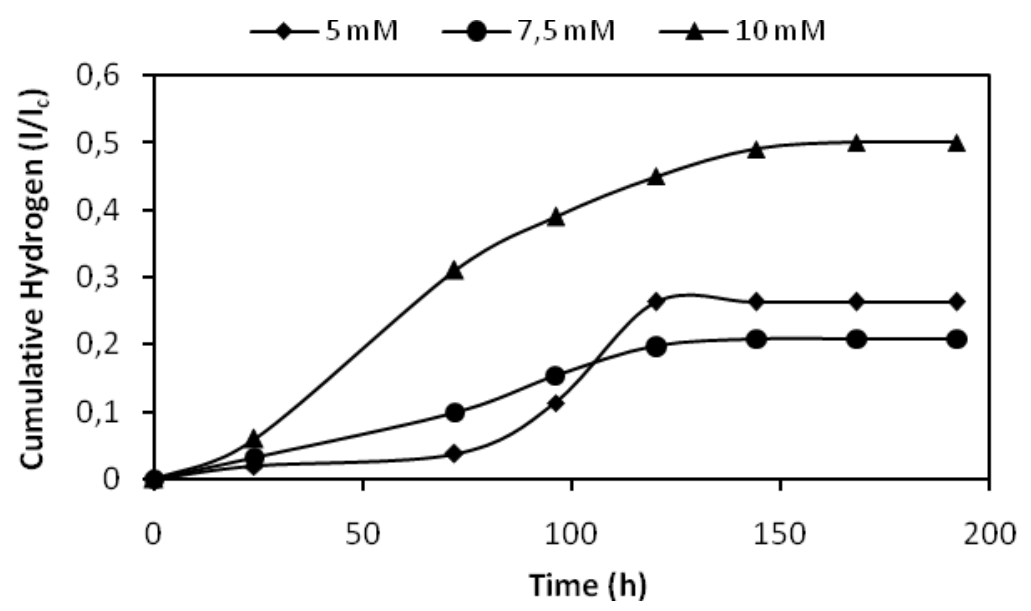

Figure 3.23 The cumulative hydrogen production by $R$. capsulatus (DSM 1710) on molasses media with different sucrose concentrations $(5,7.5$ and $10 \mathrm{mM})$. 
R. capsulatus (DSM 1710) started intensive hydrogen production after 18 hours and continued until 192 hours on molasses medium with $10 \mathrm{mM}$ sucrose. Hydrogen was produced at a slow rate after 96 hours in the process. However at $5 \mathrm{mM}$ and $7.5 \mathrm{mM}$ sucrose containing molasses media, hydrogen production was lower.

Acetic, lactic, formic, propionic and butyric acids were detected in the effluents of PBRs. The concentration of formic acid was high at high sucrose concentrations. However, acetic acid production was higher at low sucrose concentrations. Formic acid was produced through the first 48 hours, then it was consumed by $R$. capsulatus (DSM 1710). Butyric acid production was also at great amounts. Lactic acid and propionic acid were the other organic acids. Shown in Table 3.9 is the concentrations of organic acids by $R$. capsulatus (DSM 1710).

Nearly half of the sucrose in molasses was utilized for growth and hydrogen production. The initial and final sucrose concentrations in PBRs were given in Table 3.10. Figure 3.24 is given for organic acid concentrations by $R$. capsulatus (DSM 1710) on molasses medium containing $5 \mathrm{mM}$ sucrose.

Table 3.9 Concentrations of organic acids in photofermentation of $R$. capsulatus (DSM 1710) on $5 \mathrm{mM}, 7.5 \mathrm{mM}$ and $10 \mathrm{mM}$ sucrose (molasses) hydrogen production media.

\begin{tabular}{|c|c|c|c|c|c|c|}
\hline Hydrogen production media & \multicolumn{2}{|c|}{$5 \mathrm{mM}$ Sucrose } & \multicolumn{2}{c|}{$7.5 \mathrm{mM}$ Sucrose } & \multicolumn{2}{c|}{$10 \mathrm{mM}$ Sucrose } \\
\hline Organic acids & $\mathrm{C}_{0}(\mathrm{mM})$ & $\mathrm{C}_{\mathrm{f}}(\mathrm{mM})$ & $\mathrm{C}_{0}(\mathrm{mM})$ & $\mathrm{C}_{\mathrm{f}}(\mathrm{mM})$ & $\mathrm{C}_{0}(\mathrm{mM})$ & $\mathrm{C}_{\mathrm{f}}(\mathrm{mM})$ \\
\hline Acetic acid & 0.1 & 7.80 & 0 & 8.47 & 0.03 & 4.76 \\
\hline Formic acid & 0 & 0.72 & 0 & 0.69 & 0 & 0.56 \\
\hline Lactic acid & 0.02 & 2.81 & 0.05 & 1.77 & 0 & 0.68 \\
\hline Propionic acid & 0 & 2.093 & 0.02 & 0 & 0 & 0 \\
\hline Butyric acid & 0 & 1.30 & 0 & 2.48 & 0 & 3.31 \\
\hline
\end{tabular}




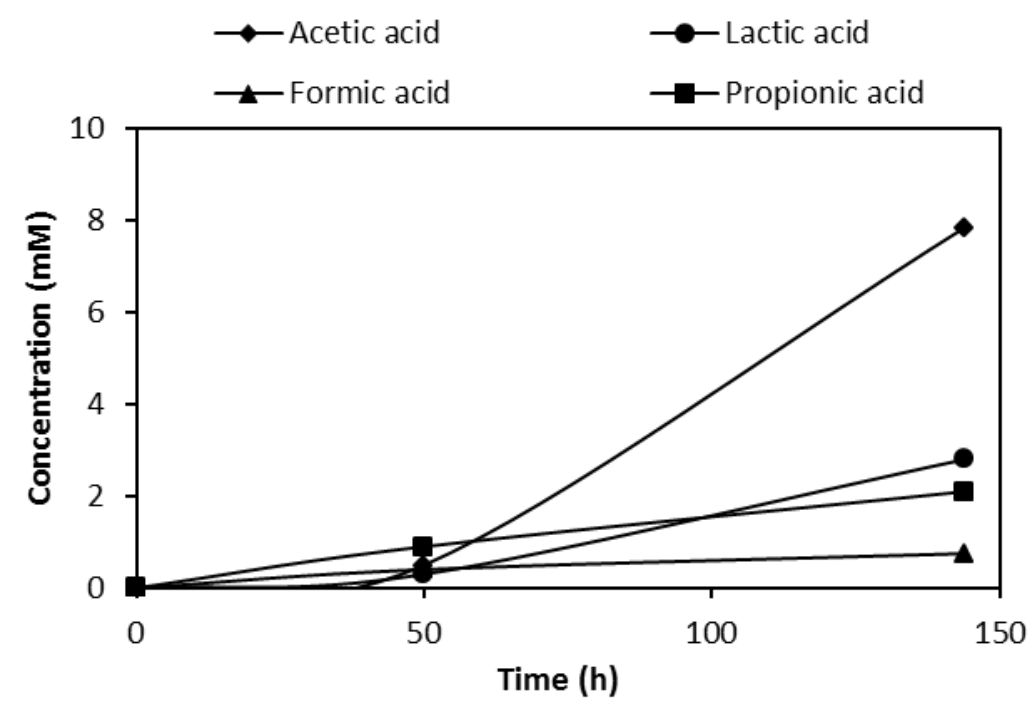

Figure 3.24 Organic acid concentrations of $R$. capsulatus (DSM 1710) on molasses medium containing $5 \mathrm{mM}$ sucrose.

Table 3.10 The utilization of sucrose by $R$. capsulatus (DSM 1710) on $5 \mathrm{mM}, 7.5$ $\mathrm{mM}$ and $10 \mathrm{mM}$ sucrose (molasses) hydrogen production media.

\begin{tabular}{|c|c|c|c|}
\hline $\begin{array}{c}\text { Sucrose concentrations } \\
\text { (PBRs) }\end{array}$ & $\mathrm{C}_{0}(\mathrm{mM})$ & $\mathrm{C}_{\mathrm{f}}(\mathrm{mM})$ & Sucrose consumption (\%) \\
\hline $5 \mathrm{mM}$ & 4.90 & 2.32 & 52.6 \\
\hline $7.5 \mathrm{mM}$ & 7.47 & 3.36 & 55.0 \\
\hline $10 \mathrm{mM}$ & 9.86 & 5.80 & 41.1 \\
\hline
\end{tabular}

\subsubsection{Experiments on $R$. capsulatus YO3 (Hup")}


In this part uptake hydrogenase deleted mutant strain of $R$. capsulatus was investigated for growth and hydrogen production. The biomass growth was shown in Figure 3.25. Exponential growth phase was pursued till 120 hours except $5 \mathrm{mM}$ sucrose containing PBR. In $5 \mathrm{mM}$ sucrose PBR, after 48 hours a steady growth phase was observed continued towards 120 hours. Then, cell concentrations began to increase again through 150 hours at which the growth restart to slow down. This situation might be caused by the production of intermediates which could inhibit growth metabolism of the bacteria. The maximum cell growth were calculated as 1.2 $\mathrm{gdcw} / \mathrm{l}_{\mathrm{c}}, 0.96 \mathrm{gdcw} / \mathrm{l}_{\mathrm{c}}$ and $1.18 \mathrm{gdcw} / \mathrm{l}_{\mathrm{c}}$ respectively.

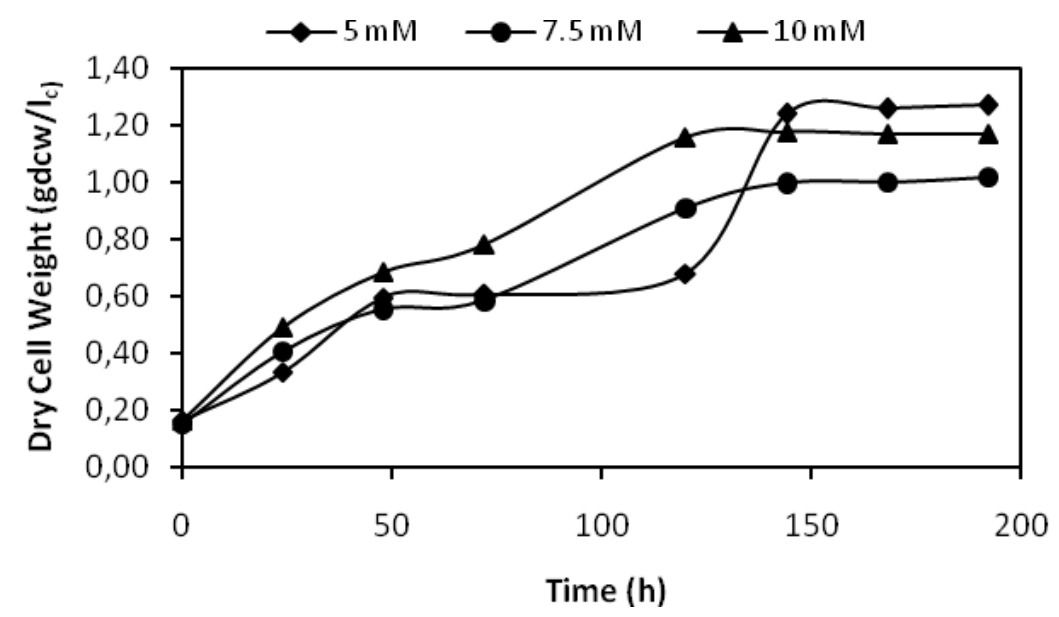

Figure 3.25 The growth of $R$. capsulatus YO3 (Hup-) in different sucrose concentrations $(5,7.5$ and $10 \mathrm{mM})$ by dilutions of molasses. 


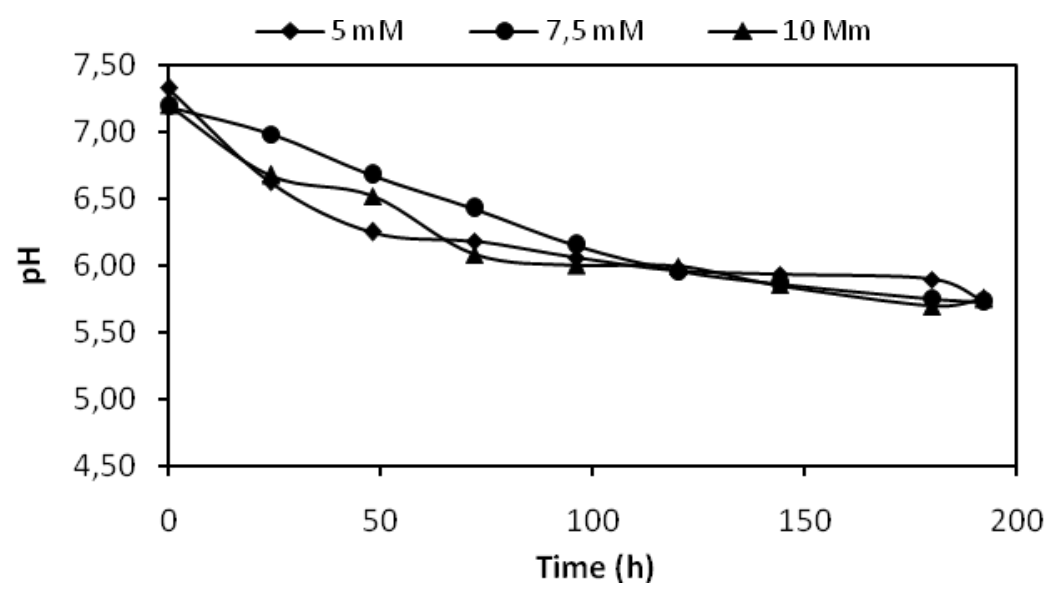

Figure 3.26 The $\mathrm{pH}$ variation during hydrogen production by $R$. capsulatus YO3 (Hup ${ }^{-}$) on molasses with different sucrose concentrations $(5,7.5$ and $10 \mathrm{mM})$.

The pH started to drop in each PBRs. The final pHs in all PBRs were around 5.5-5.8. Figure 3.26 shows the changes of $\mathrm{pH}$ in the PBRs. The complicated ingredients of molasses may bring about the fall in $\mathrm{pH}$ levels. Another strong reason might be the production of organic acids or other $\mathrm{pH}$ lowering compounds in photofermentation effluent.

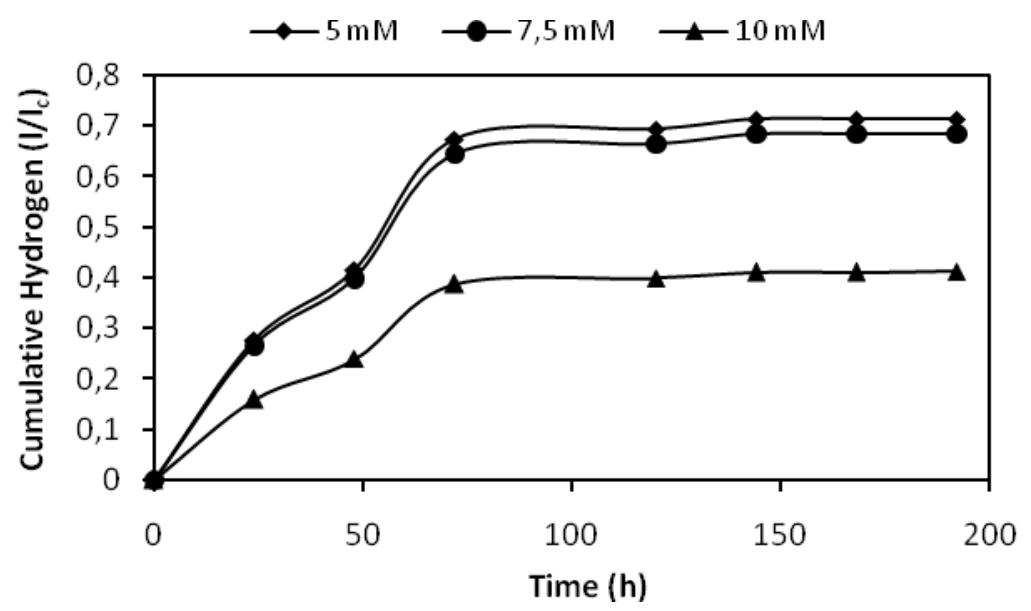

Figure 3.27 Figure 3.27 The cumulative hydrogen production by $R$. capsulatus YO3 (Hup-) on molasses with different sucrose concentrations (5, 7.5 and $10 \mathrm{mM})$. 
Figure 3.27 shows the cumulative hydrogen production of $R$. capsulatus YO3 (Hup ${ }^{-}$). More hydrogen was produced in $5 \mathrm{mM}$ and $7.5 \mathrm{mM}$ PBRs. The rate of hydrogen production was similar in both PBRs with a cumulative production of $0.6-0.71 / 1_{c}$. The produced hydrogen was about two times higher than that of $10 \mathrm{mM}$ PBR. It can be inferred that the hydrogen production metabolism was predominant over growth metabolism at sucrose concentrations lower than $10 \mathrm{mM}$.

Acetic acid produced and consumed simultaneously in all the PBRs. Formic acid first increase until $72^{\text {th }}$ hours then drops. The concentration of propionic acid increase after $48^{\text {th }}$ hours. More propionic acid was produced by R.capsulatus YO3 (Hup ${ }^{-}$) rather than other bacterial strains. Lactic acid was produced and then used by the bacteria. Table 3.11 shows the initial and final concentrations of organic acids.

The sucrose was consumed more in $5 \mathrm{mM}$ PBR than the others. The consumption of sucrose by R.capsulatus YO3 (Hup') was shown in Table 3.12.

Table 3.11 Concentrations of organic acids in photofermentation of R.capsulatus YO3 (Hup ${ }^{-}$) on $5 \mathrm{mM}, 7.5 \mathrm{mM}$ and $10 \mathrm{mM}$ sucrose (molasses) hydrogen production media.

\begin{tabular}{|c|c|c|c|c|c|c|}
\hline Hydrogen production media & \multicolumn{2}{|c|}{$5 \mathrm{mM}$ Sucrose } & \multicolumn{2}{c|}{$7.5 \mathrm{mM}$ Sucrose } & \multicolumn{2}{c|}{$10 \mathrm{mM}$ Sucrose } \\
\hline Organic products & $\mathrm{C}_{0}(\mathrm{mM})$ & $\mathrm{C}_{\mathrm{f}}(\mathrm{mM})$ & $\mathrm{C}_{0}(\mathrm{mM})$ & $\mathrm{C}_{\mathrm{f}}(\mathrm{mM})$ & $\mathrm{C}_{0}(\mathrm{mM})$ & $\mathrm{C}_{\mathrm{f}}(\mathrm{mM})$ \\
\hline Acetic acid & 0 & 1.93 & 0.02 & 0.17 & 0 & 0.07 \\
\hline Formic acid & 0 & 0.15 & 0 & 3.87 & 0 & 3.49 \\
\hline Lactic acid & 0 & 3.69 & 0 & 0.09 & 0 & 0.05 \\
\hline
\end{tabular}




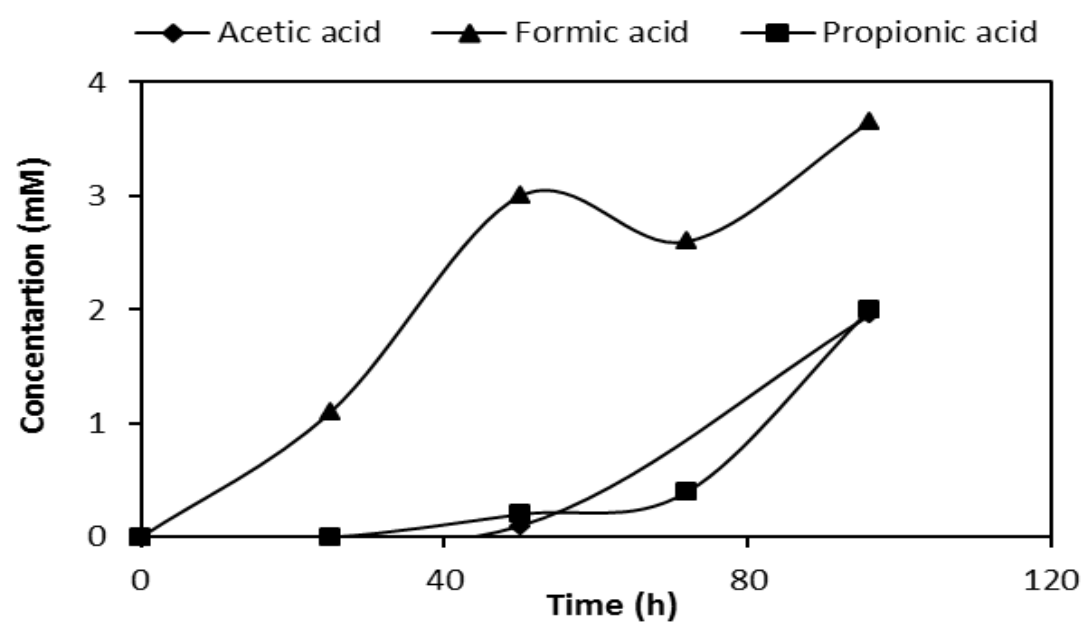

Figure 3.28 Acetic, lactic and propionic acid concentraitons during hydrogen production by $R$. capsulatus YO3 (Hup-) on molasses medium with $5 \mathrm{mM}$ sucrose.

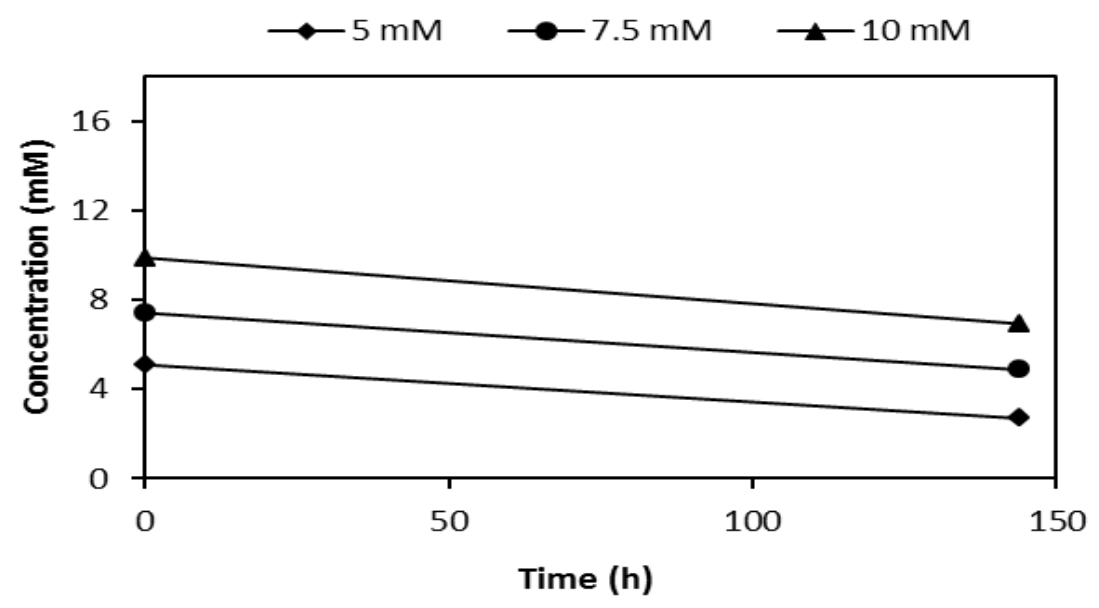

Figure 3.29 The consumption of sucrose by R. capsulatus YO3 (Hup ${ }^{-}$). 
Table 3.12 The utilization of sucrose by R.capsulatus YO3 (Hup ${ }^{-}$) on $5 \mathrm{mM}, 7.5 \mathrm{mM}$ and $10 \mathrm{mM}$ sucrose (molasses) hydrogen production media.

\begin{tabular}{|c|c|c|c|}
\hline $\begin{array}{c}\text { Sucrose concentrations } \\
\text { (PBRs) }\end{array}$ & $\mathrm{C}_{0}(\mathrm{mM})$ & $\mathrm{C}_{\mathrm{f}}(\mathrm{mM})$ & Sucrose consumption (\%) \\
\hline $5 \mathrm{mM}$ & 5.10 & 2.70 & 47.0 \\
\hline $7.5 \mathrm{mM}$ & 7.42 & 4.87 & 34.3 \\
\hline $10 \mathrm{mM}$ & 9.88 & 6.93 & 29.8 \\
\hline
\end{tabular}

\subsubsection{Experiments on $R$. palustris (DSM 127)}

The growth, $\mathrm{pH}$ and hydrogen production by $R$. palustris (DSM 127) on molasses media containing different concentrations of sucrose $(5 \mathrm{mM}, 7.5 \mathrm{mM}$ and $10 \mathrm{mM})$ were investigated for 192 hours. Shown in Figure 3.30 is the growth of $R$. palustris (DSM 127) on hydrogen production media.The biomass growth of $10 \mathrm{mM}$ sucrose was greater than the other two PBRs. The maximum biomass was observed at 144 hours as $0.4 \mathrm{gdcw} / \mathrm{l}_{\mathrm{c}}$.

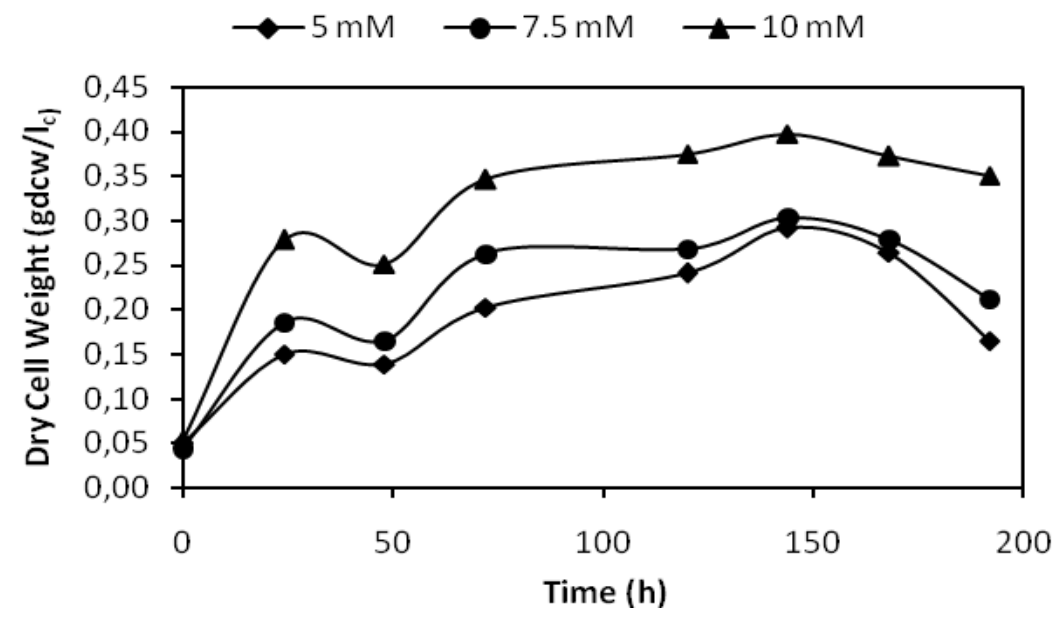

Figure 3.30 The growth of $R$. palustris (DSM 127) on molasses media with different sucrose concentrations $(5,7.5$ and $10 \mathrm{mM})$. 
The change of $\mathrm{pH}$ in PBRs was illustrated in Figure 3.31 The $\mathrm{pH}$ decreased from 7.3-7.4 to 6.5 in $5 \mathrm{mM}$ and $7.5 \mathrm{mM}$ sucrose, whereas the final $\mathrm{pH}$ was 5.8 in $10 \mathrm{mM}$ sucrose. It was stabilized after 72 hours by all the three PBRs. This may be resulted due the consumption of organic acids by the carbon metabolism of PNS bacteria. Given in Figure 3.32 is the cumulative hydrogen production of $R$. palustris (DSM 127). The cumulative hydrogen production of $10 \mathrm{mM}$ sucrose PBR was $1.41 / 1_{\mathrm{c}}$ and it was higher than the other PBRs. $1.21 / 1_{c}$ and $1.01 / l_{c}$ hydrogen was produced by 7.5 $\mathrm{Mm}$ and $5 \mathrm{mM}$ sucrose from molasses media, respectively. Hydrogen production was produced mostly during 0-48 hours time interval.

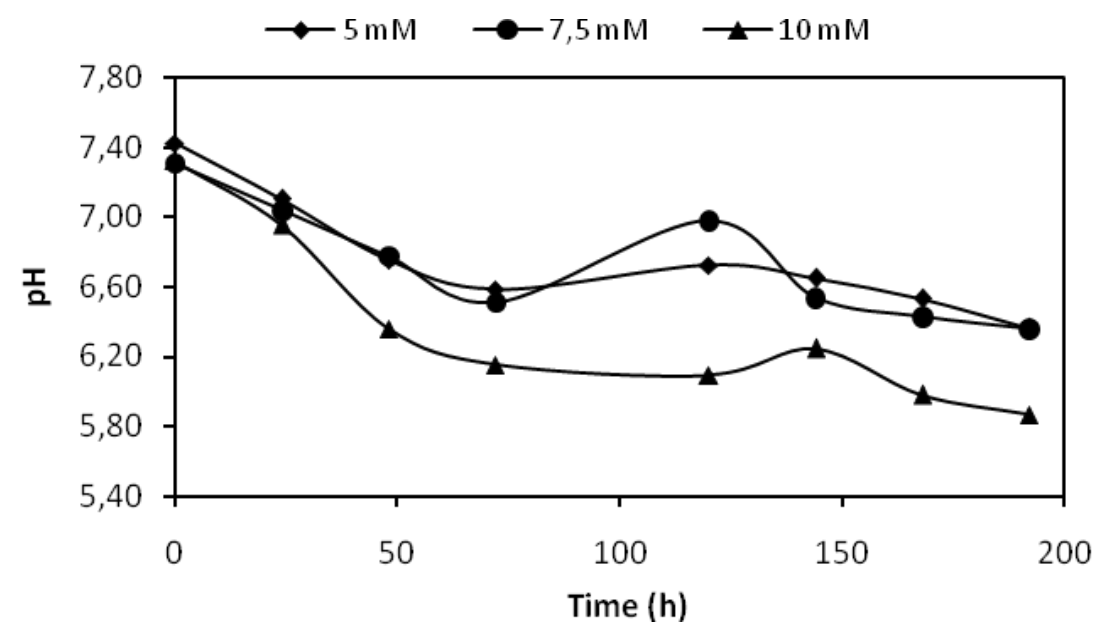

Figure 3.31 The variation in $\mathrm{pH}$ during hydrogen production by $R$. palustris (DSM 127) on molasses media with different sucrose concentrations $(5,7.5$ and $10 \mathrm{mM})$. 


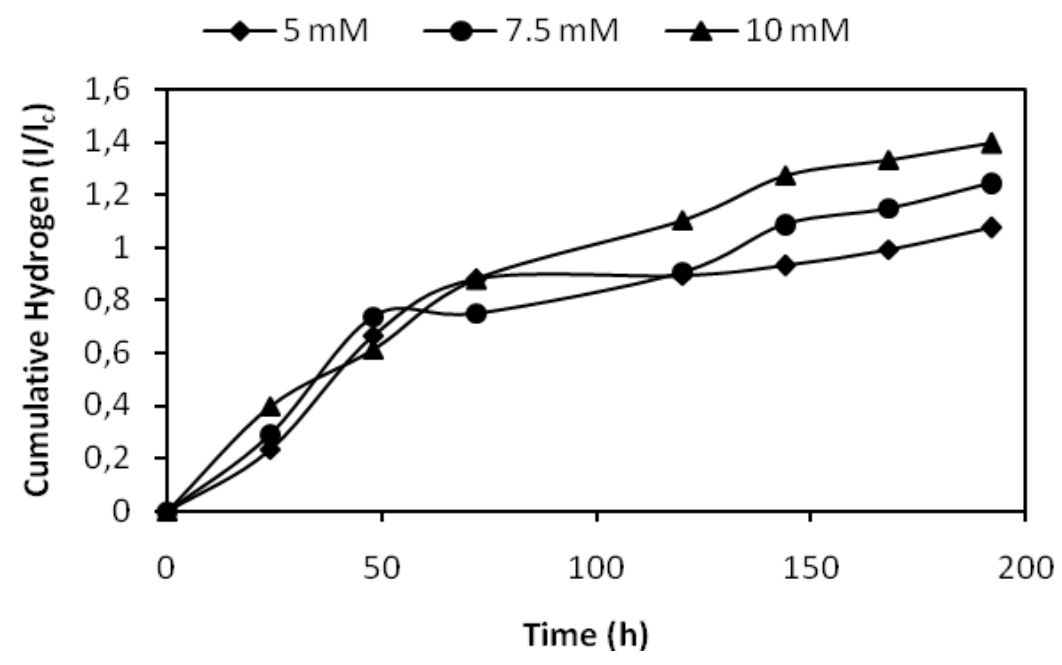

Figure 3.32 The cumulative hydrogen production of $R$. palustris (DSM 127) on molasses media with different sucrose concentrations $(5,7.5$ and $10 \mathrm{mM})$.

Table 3.13 shows the organic acid production and consumption in PBRs by $R$. palustris (DSM 127). Acetate was mostly produced in PBR with $10 \mathrm{mM}$ sucrose, while formic acid was predominant product in $5 \mathrm{mM}$ and $7.5 \mathrm{mM}$ sucrose containing PBRs through the process. Lactic acid and and acetic acid were highly produced in $10 \mathrm{mM}$ sucrose containing PBR whereas formic acid concentration nearly constant. Trace amount of propionic was also present in the same medium.

The sucrose consumption of the R. palustris (DSM 127) was given in Table 3.14. The percentages of sucrose consumption by $5 \mathrm{mM}$ PBR, $7.5 \mathrm{mM}$ and $10 \mathrm{mM}$ photobioreactors were measured as $51 \%, 59 \%$ and $28 \%$, respectively. 
Table 3.13 Concentrations of organic acids in photofermentation of $R$. palustris (DSM 127) on $5 \mathrm{mM}, 7.5 \mathrm{mM}$ and $10 \mathrm{mM}$ sucrose (molasses) hydrogen production media.

\begin{tabular}{|c|c|c|c|c|c|c|}
\hline Hydrogen production media & \multicolumn{2}{|c|}{$5 \mathrm{mM}$ Sucrose } & \multicolumn{2}{c|}{$7.5 \mathrm{mM}$ Sucrose } & \multicolumn{2}{c|}{$10 \mathrm{mM}$ Sucrose } \\
\hline Organic acids & $\mathrm{C}_{0}(\mathrm{mM})$ & $\mathrm{C}_{\mathrm{f}}(\mathrm{mM})$ & $\mathrm{C}_{0}(\mathrm{mM})$ & $\mathrm{C}_{\mathrm{f}}(\mathrm{mM})$ & $\mathrm{C}_{0}(\mathrm{mM})$ & $\mathrm{C}_{\mathrm{f}}(\mathrm{mM})$ \\
\hline Acetic acid & 0.967 & 1.624 & 1.435 & 1.246 & 0.692 & 6.539 \\
\hline Formic acid & 3.148 & 6.878 & 4.228 & 9.371 & 3.726 & 3.738 \\
\hline Lactic acid & 1.04 & 0.92 & 1.34 & 0.81 & 1.15 & 5.37 \\
\hline
\end{tabular}

Table 3.14 The utilization of sucrose by $R$. palustris (DSM 127) on $5 \mathrm{mM}, 7.5 \mathrm{mM}$ and $10 \mathrm{mM}$ sucrose (molasses) hydrogen production media.

\begin{tabular}{|c|c|c|c|}
\hline $\begin{array}{c}\text { Sucrose concentrations } \\
\text { (PBRs) }\end{array}$ & $\mathrm{C}_{0}(\mathrm{mM})$ & $\mathrm{C}_{\mathrm{f}}(\mathrm{mM})$ & Sucrose consumption (\%) \\
\hline $5 \mathrm{mM}$ & 4.98 & 2.43 & 51.2 \\
\hline $7.5 \mathrm{mM}$ & 7.41 & 3.02 & 59.2 \\
\hline $10 \mathrm{mM}$ & 9.58 & 6.9 & 28.0 \\
\hline
\end{tabular}

\subsubsection{Experiments on R. sphaeroides O.U.001 (DSM 5864)}

The biomass growth of $R$. sphaeroides O.U.001 (DSM 5864) in $10 \mathrm{mM}$ sucrose PBR was the highest as $0.8 \mathrm{gdcw} / \mathrm{l}_{\mathrm{c}}$ during the operation. Shown in Figure 3.33 is the biomass growth of $R$. sphaeroides O.U.001 (DSM 5864).

The growth of $5 \mathrm{mM}$ sucrose PBR showed a fluctuated growth curve, but the maximum hydrogen was produced in this PBR. The maximum hydrogen production 
was $0.661 / l_{c}, 0.41 / l_{c}$ and $0.601 / l_{c}$ in order of increasing sucrose concentrations (57.5-10 $\mathrm{mM}$ ) and given in Figure 3.35.

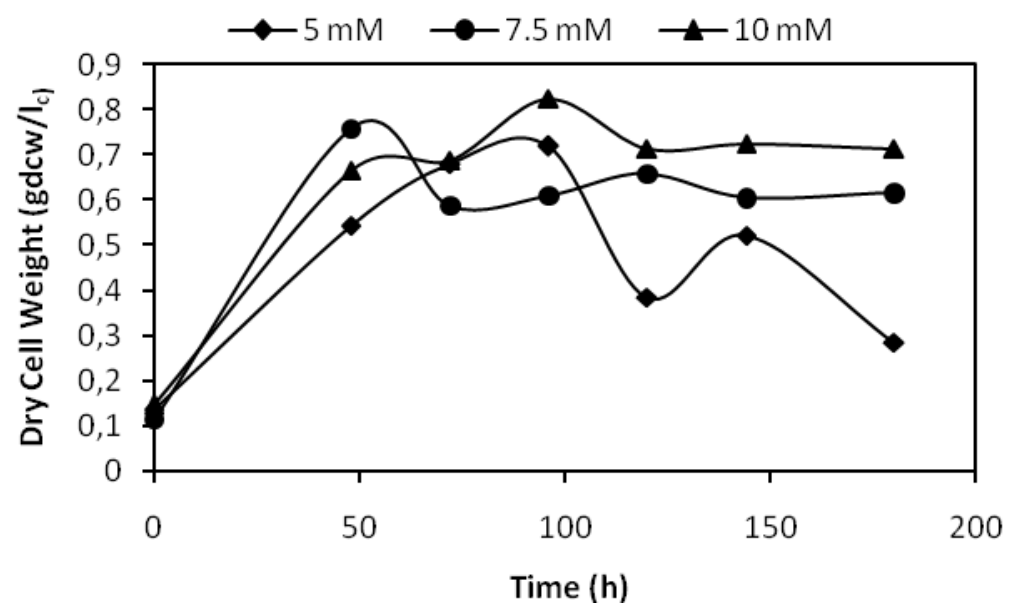

Figure 3.33 The growth of $R$. sphaeroides O.U.001 (DSM 5864) on molasses media with different sucrose concentrations $(5,7.5$ and $10 \mathrm{mM})$.

R. sphaeroides O.U.001 (DSM 5864) had a more stable pH through the 180 hours photofermentation especially in $7.5 \mathrm{mM}$ and $10 \mathrm{mM}$ sucrose PBRs. The range of measured $\mathrm{pH}$ values were 6.2-6.8 during the operation time and shown in Figure 3.34. $R$. sphaeroides O.U.001 are not able to grow under pH of 6.0 (Sasikala et al., 1995). 


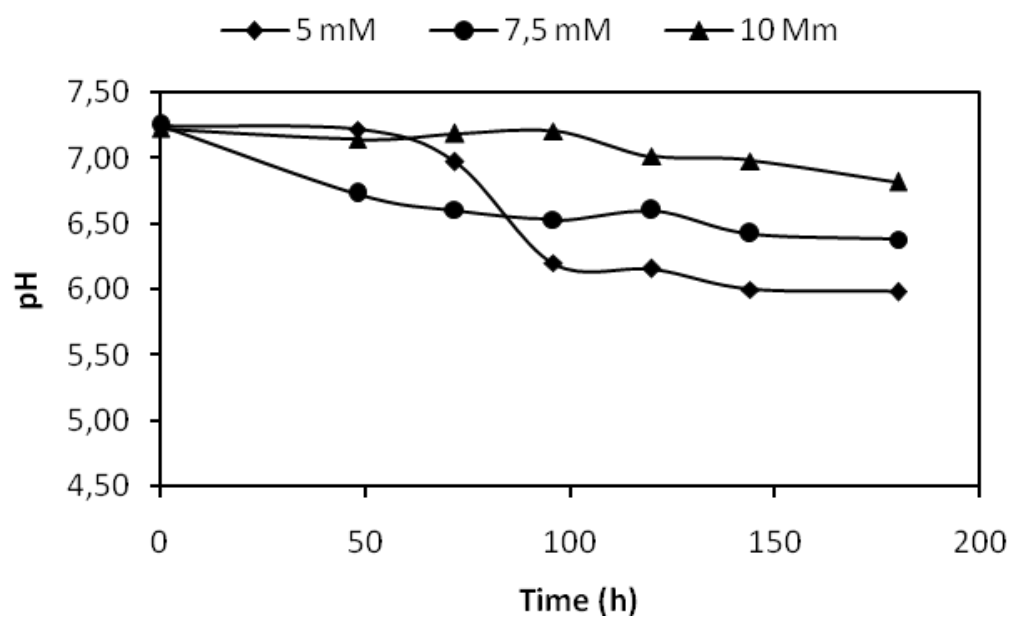

Figure 3.34 The variation in $\mathrm{pH}$ during hydrogen production by $R$. sphaeroides O.U.001 (DSM 5864) on molasses media with different sucrose concentrations (5, 7.5 and $10 \mathrm{mM})$.

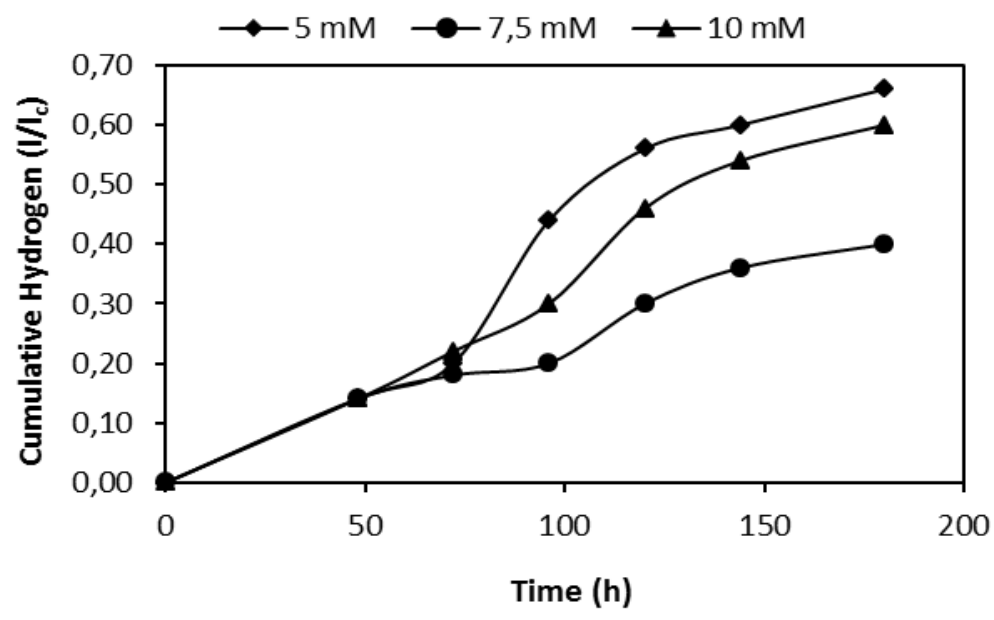

Figure 3.35 The cumulative hydrogen production by $R$. sphaeroides O.U.001 (DSM $5864)$ on molasses media with different sucrose concentrations $(5,7.5$ and $10 \mathrm{mM})$.

Lactic acid was first consumed and then produced again. It was probably the first preferred substrate rather than others. Sevinç (2010) also reported that lactic acid was used primarily by the $R$. capsulatus DSM 1710 in a acetate-lactate hydrogen 
medium. Acetic acid seems to be the secondary utilized organic acid in the hydrogen production medium. In $5 \mathrm{mM}$ and $10 \mathrm{~mm}$ PBRs, formic acid was consumed through first 72 hours. After that, the concentration of formic acid increased dramatically. Table 3.15 shows the concentrations of organic acids during photofermentation of $R$. Sphaeroides O.U.001. Formic acid production with $R$. sphaeroides O.U.001 was reported due to low light intensity (Eroğlu, 2008). All of the organic acids were produced after $72^{\text {th }}$ hours in $7.5 \mathrm{mM}$ sucrose medium. Sucrose consumption was approximately $50 \%$ in all of the PBRs, and shown in Table 3.16.

Table 3.15 Concentrations of organic acids in photofermentation of $R$. sphaeroides O.U.001 (DSM 5864) on $5 \mathrm{mM}, 7.5 \mathrm{mM}$ and $10 \mathrm{mM}$ sucrose (molasses) hydrogen production media.

\begin{tabular}{|c|c|c|c|c|c|c|}
\hline Hydrogen production media & \multicolumn{2}{|c|}{$5 \mathrm{mM}$ Sucrose } & \multicolumn{2}{c|}{$7.5 \mathrm{mM}$ Sucrose } & \multicolumn{2}{c|}{$10 \mathrm{mM}$ Sucrose } \\
\hline Organic acids & $\mathrm{C}_{0}(\mathrm{mM})$ & $\mathrm{C}_{\mathrm{f}}(\mathrm{mM})$ & $\mathrm{C}_{0}(\mathrm{mM})$ & $\mathrm{C}_{\mathrm{f}}(\mathrm{mM})$ & $\mathrm{C}_{0}(\mathrm{mM})$ & $\mathrm{C}_{\mathrm{f}}(\mathrm{mM})$ \\
\hline Acetic acid & 0.241 & 3.298 & 0.365 & 0.784 & 1.129 & 0.313 \\
\hline Formic acid & 0.958 & 5.373 & 1.509 & 11.405 & 3.417 & 4.944 \\
\hline Lactic acid & 0.41 & 2.37 & 0.59 & 1.07 & 1.22 & 0.03 \\
\hline
\end{tabular}

Table 3.16 The utilization of sucrose by $R$. palustris (DSM 127) on $5 \mathrm{mM}, 7.5 \mathrm{mM}$ and $10 \mathrm{mM}$ sucrose (molasses) hydrogen production media.

\begin{tabular}{|c|c|c|c|}
\hline $\begin{array}{c}\text { Sucrose concentrations } \\
(\text { PBRs })\end{array}$ & $\mathrm{C}_{0}(\mathrm{mM})$ & $\mathrm{C}_{\mathrm{f}}(\mathrm{mM})$ & Sucrose consumption (\%) \\
\hline $5 \mathrm{mM}$ & 5.12 & 2.51 & 50.9 \\
\hline $7.5 \mathrm{mM}$ & 7.56 & 3.54 & 53.1 \\
\hline $10 \mathrm{mM}$ & 9.53 & 4.47 & 53.0 \\
\hline
\end{tabular}




\subsection{Comparison of the Experiments}

R. palustris (DSM 127) had the highest biomass growth $\left(1.5 \mathrm{gdcw} / \mathrm{l}_{\mathrm{c}}\right)$ on $5 \mathrm{mM}$ defined sucrose media. On the other hand, R. capsulatus YO3 (Hup') have grown well on $5 \mathrm{mM}$ sucrose from molasses medium with a maximum biomass of 1.25 gdcw/1 . R. sphaeroides O.U.001 showed good growth profiles in both defined and molasses media. A more stable $\mathrm{pH}$ change could be the reason of having such growth curves. Total hydrogen production was greater with $R$. palustris (DSM 127) than the other bacteria in both defined sucrose and molasses hydrogen media. In $50 \mathrm{ml}$ PBRs, 3.34 and $3.10 \mathrm{mmol}$ hydrogen were produced during 192 hours by $R$. palustris (DSM 127) on defined sucrose and molasses media respectively. Figure 3.17 and Figure 3.19 is given for total hydrogen production of PNS bacteria through certain operation periods.

Hydrogen productivities were generally in higher values on defined media than molasses media. On the contrary, substrate conversion efficiencies were greater on molasses media than defined media. This is actually a pleasurable situation in terms of utilization of molasses. Shown in Figure 3.32 and Figure 3.33 are the comparison of hydrogen productivities. The productivities of $R$. capsulatus YO3 (Hup ) on molasses was much higher than that of $R$. capsulatus (DSM 1710). Özgür et al., (2009) reported that $R$. capsulatus YO3 (Hup ${ }^{-}$) had better productivity than $R$. capsulatus (DSM 1710) on $30 \mathrm{mM}$ acetate/7.5 mM Lactate. 
Table 3.17 Duration of the processes and total hydrogen production of different PNS bacteria on defined sucrose media in $50 \mathrm{ml}$ bioreactors.

\begin{tabular}{|c|c|c|c|}
\hline Microorganism & Sucrose concentration (mM) & Duration of process (h) & $\begin{array}{c}\text { Total Hydrogen } \\
(\mathbf{m m o l ~ H})\end{array}$ \\
\hline \multirow{3}{*}{ R. capsulatus (DSM 1710) } & 5 & 180 & 0.45 \\
\hline & 7.5 & 180 & 1.91 \\
\hline & 10 & 180 & 1.34 \\
\hline \multirow{3}{*}{ R. capsulatus YO3 (Hup-) } & 5 & 216 & 1.78 \\
\hline & 7.5 & 216 & 1.11 \\
\hline & 10 & 216 & 0.67 \\
\hline \multirow{3}{*}{ R. palustris (DSM 127) } & 5 & 192 & 3.03 \\
\hline & 7.5 & 192 & 3.34 \\
\hline & 10 & 192 & 2.46 \\
\hline \multirow{3}{*}{ R. sphaeroides O.U.001 } & 5 & 180 & 1,91 \\
\hline & 7.5 & 180 & 1,34 \\
\hline & 10 & 180 & 1,65 \\
\hline
\end{tabular}

It was observed that molasses media had generally more substrate conversion efficiency than defined sucrose media. $96.6 \%$ efficiency was obtained by $R$. palustris (DSM 127) on $10 \mathrm{mM}$ sucrose from molasses. Substrate conversion efficiencies of R. palustris (DSM 127) and R. sphaeroides O.U.001 were 53.3\% and $41.7 \%$ on $5 \mathrm{mM}$ defined sucrose media.

Figure 3.32 is given for substrate conversion efficiencies of PNS bacteria. The experimental results on sucrose indicated that substrate conversion efficiencies varied from $7.41 \%$ to $96.6 \%$ by PNS bacteria. 


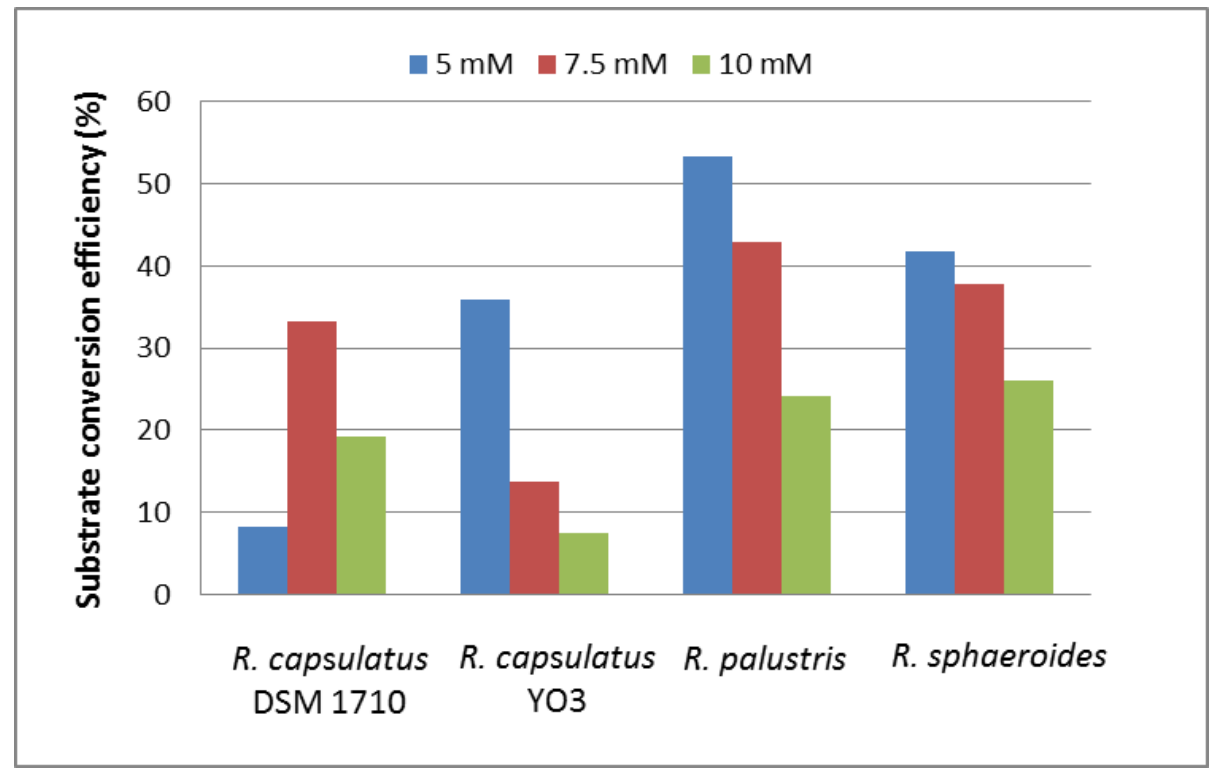

Figure 3.36 The substrate conversion efficiencies of different PNS bacteria on various sucrose concentrations in $50 \mathrm{ml}$ bioreactors.

The concentration of sucrose also affects the substrate conversion efficiencies and hydrogen productivities (Figure 3.36). These parameters were generally lower when sucrose concentration is increased.

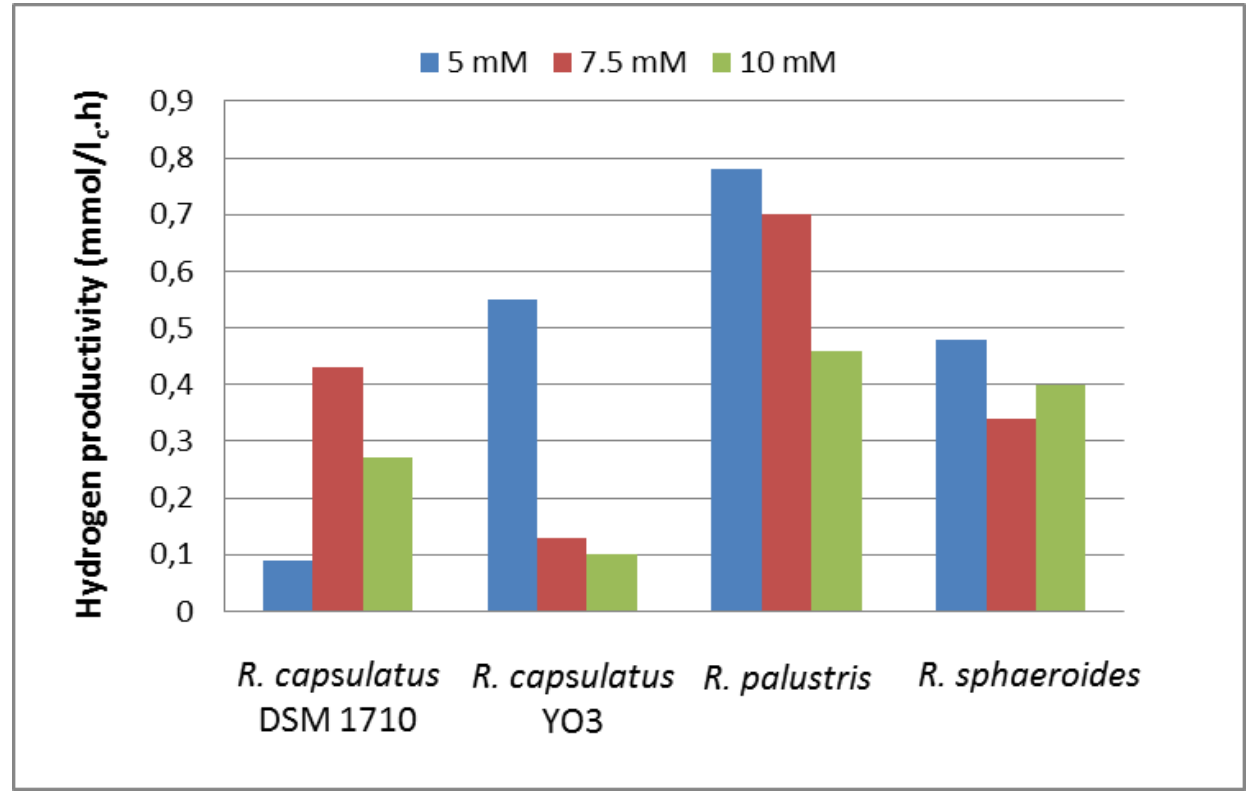

Figure 3.37 The hydrogen productivities of different PNS bacteria on various sucrose concentrations in $50 \mathrm{ml}$ bioreactors. 
Table 3.18 Summary of the results with different PNS bacteria on defined sucrose media in $50 \mathrm{ml}$ bioreactors.

\begin{tabular}{|c|c|c|c|c|c|c|}
\hline $\begin{array}{l}\text { Microorganis } \\
\text { m }\end{array}$ & $\begin{array}{c}\text { Sucrose } \\
\text { concentration } \\
(\mathbf{m M})\end{array}$ & $\begin{array}{l}\text { Biomass } \\
\left(\mathrm{gdcw} / \mathrm{l}_{\mathrm{c}}\right)\end{array}$ & $\begin{array}{l}\text { Hydrogen } \\
\text { productivity } \\
(\text { mmol///c.h) }\end{array}$ & $\begin{array}{c}\text { Substrate } \\
\text { conversion } \\
\text { efficiency } \\
(\%)\end{array}$ & $\begin{array}{c}\text { Sucrose } \\
\text { consumption } \\
(\%)\end{array}$ & $\begin{array}{c}\text { Light } \\
\text { conversion } \\
\text { efficiency } \\
(\%)\end{array}$ \\
\hline \multirow{3}{*}{$\begin{array}{l}\text { R. capsulatus } \\
\text { DSM } 1710\end{array}$} & 5 & 0.60 & 0.09 & 8.14 & 100 & 0.07 \\
\hline & 7.5 & 0.58 & 0.43 & 33.2 & 71.0 & 0.31 \\
\hline & 10 & 0.57 & 0.27 & 19.3 & 50.04 & 0.21 \\
\hline \multirow{3}{*}{$\begin{array}{l}\text { R. capsulatus } \\
\text { YO3 (Hup`) }\end{array}$} & 5 & 0.62 & 0.55 & 35.9 & 85.0 & 0.24 \\
\hline & 7.5 & 0.55 & 0.13 & 13.8 & 85.5 & 0.15 \\
\hline & 10 & 0.51 & 0.10 & 7.41 & 70.0 & 0.09 \\
\hline \multirow{3}{*}{$\begin{array}{l}\text { R. palustris } \\
\text { DSM } 127\end{array}$} & 5 & 1.40 & 0.78 & 53.3 & 96.1 & 0.46 \\
\hline & 7.5 & 1.50 & 0.70 & 43.0 & 81.1 & 0.51 \\
\hline & 10 & 1.10 & 0.46 & 24.2 & 88.9 & 0.37 \\
\hline \multirow{3}{*}{$\begin{array}{l}\text { R. sphaeroides } \\
\text { O.U.001 }\end{array}$} & 5 & 0.60 & 0.48 & 41.7 & 78.6 & 0.30 \\
\hline & 7.5 & 0.68 & 0.34 & 37.8 & 40.0 & 0.22 \\
\hline & 10 & 0.68 & 0.40 & 26.0 & 53.5 & 0.27 \\
\hline
\end{tabular}


Table 3.19 Duration of the processes and total hydrogen production of different PNS bacteria on molasses in $50 \mathrm{ml}$ bioreactors.

\begin{tabular}{|c|c|c|c|}
\hline Microorganism & Sucrose concentration (mM) & Duration of process (h) & $\begin{array}{c}\text { Total Hydrogen } \\
\left(\mathbf{m m o l ~ H}_{\mathbf{2}}\right)\end{array}$ \\
\hline \multirow{3}{*}{ R. capsulatus (DSM 1710) } & 5 & 192 & 0.59 \\
\hline & 7.5 & 192 & 0.47 \\
\hline & 10 & 192 & 1.11 \\
\hline \multirow{3}{*}{ R. capsulatus $\mathrm{YO}$ (Hup`) } & 5 & 192 & 1.59 \\
\hline & 7.5 & 192 & 1.20 \\
\hline & 10 & 192 & 0.69 \\
\hline \multirow{3}{*}{ R. palustris (DSM 127) } & 5 & 192 & 2.39 \\
\hline & 7.5 & 192 & 2.76 \\
\hline & 10 & 192 & 3.10 \\
\hline \multirow{3}{*}{ R. sphaeroides O.U.001 } & 5 & 180 & 1.47 \\
\hline & 7.5 & 180 & 0.89 \\
\hline & 10 & 180 & 1.34 \\
\hline
\end{tabular}

Shown in Figure 3.34 and Figure 3.35 are substrate conversion efficiencies and hydrogen productivities of PNS bacteria on molasses with different sucrose concentrations (5-7.5-10 $\mathrm{mM})$. 
Table 3.20 Summary of the results with different PNS bacteria on molasses in $50 \mathrm{ml}$ bioreactors.

\begin{tabular}{|c|c|c|c|c|c|c|}
\hline Microorganism & $\begin{array}{c}\text { Sucrose } \\
\text { concentration } \\
(\mathbf{m M})\end{array}$ & $\begin{array}{l}\text { Biomass } \\
\left(\text { gdcw// } /_{c}\right)\end{array}$ & $\begin{array}{l}\text { Hydrogen } \\
\text { productivity } \\
\left(\mathbf{m m o l} / \mathrm{l}_{\mathrm{c}} \cdot \mathrm{h}\right)\end{array}$ & $\begin{array}{c}\text { Substrate } \\
\text { conversion } \\
\text { efficiency } \\
(\%)\end{array}$ & $\begin{array}{c}\text { Sucrose } \\
\text { consumption } \\
(\%)\end{array}$ & $\begin{array}{c}\text { Light } \\
\text { conversion } \\
\text { efficiency } \\
(\%)\end{array}$ \\
\hline \multirow{2}{*}{ R. capsulatus } & 5 & 0.6 & 0.20 & 18.9 & 52.6 & 0.09 \\
\hline & 7.5 & 0.3 & 0.07 & 9.45 & 55.0 & 0.07 \\
\hline DSM 1710 & 10 & 0.2 & 0.18 & 22.9 & 41.1 & 0.16 \\
\hline \multirow{2}{*}{ R. capsulatus } & 5 & 1.25 & 0.41 & 55.2 & 47.0 & 0.243 \\
\hline & 7.5 & 0.98 & 0.40 & 39.2 & 34.3 & 0.18 \\
\hline YO3 (Hup) & 10 & 1.21 & 0.24 & 19.6 & 29.8 & 0.10 \\
\hline \multirow{3}{*}{$\begin{array}{l}\text { R. palustris } \\
\text { DSM } 127\end{array}$} & 5 & 0.4 & 0.55 & 78.3 & 51.2 & 0.36 \\
\hline & 7.5 & 0.3 & 0.47 & 52.7 & 59.2 & 0.42 \\
\hline & 10 & 0.28 & 0.54 & 96.6 & 28.0 & 0.47 \\
\hline \multirow{3}{*}{$\begin{array}{l}\text { R. sphaeroides } \\
\text { O.U.001 }\end{array}$} & 5 & 0.7 & 0.27 & 47.1 & 50.9 & 0.23 \\
\hline & 7.5 & 0.75 & 0.12 & 18.5 & 53.1 & 0.15 \\
\hline & 10 & 0.8 & 0.18 & 22.0 & 53.0 & 0.21 \\
\hline
\end{tabular}

The substrate conversion efficiencies and hydrogen productivities on molasses are shown in Figure 3.38 and 3.39, respectively.

Sucrose consumption (\%) was calculated by measuring the final and initial sucrose concentrations in the media via HPLC analysis. Table 3.18 shows the consumption of sucrose by PNS bacteria. R. palustris (DSM 127) and R. capsulatus (DSM 1710) consumed more sucrose than the other strains on molasses. The consumption of sucrose were of $59.2 \%$ and $55.0 \%$ by those bacteria. The range of sucrose consumption varied between $41.1-59.2 \%$ on molasses media. 


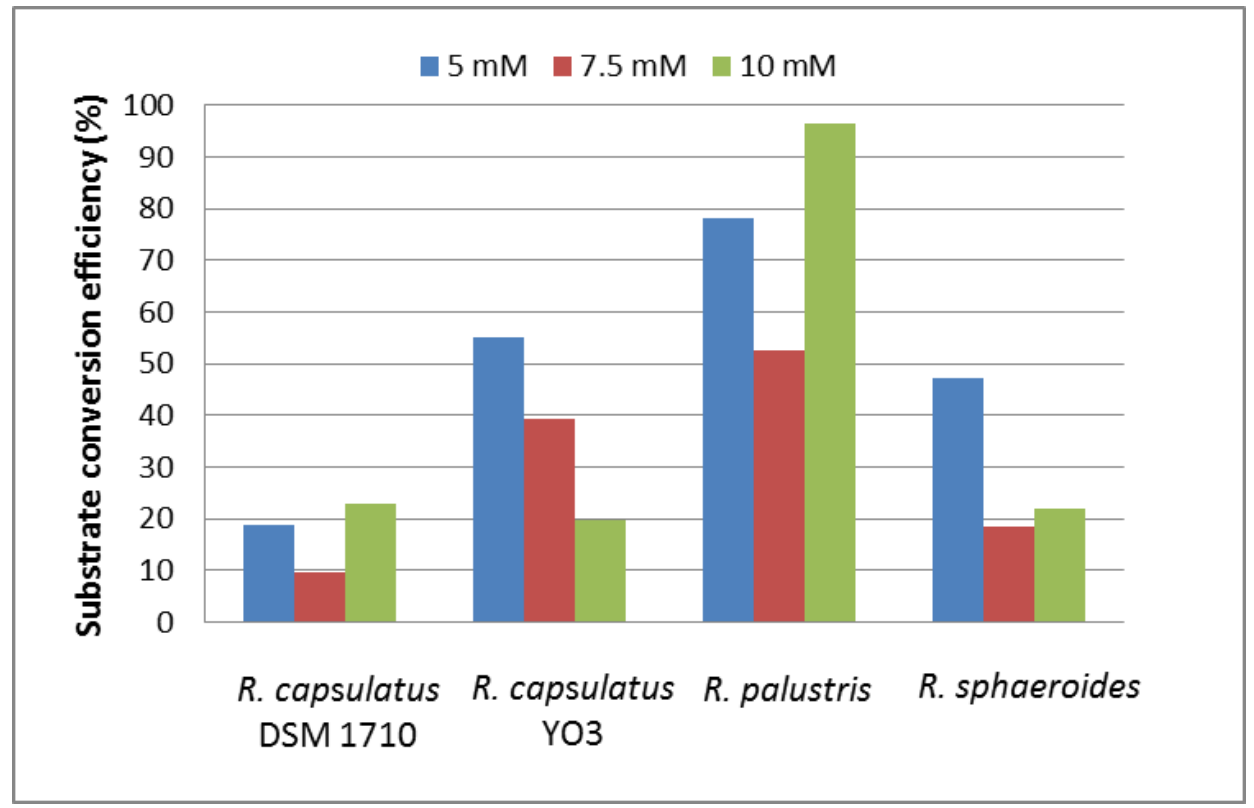

Figure 3.38 The substrate conversion efficiencies of different PNS bacteria on molasses with different sucrose concentrations (5-7.5-10 mM).

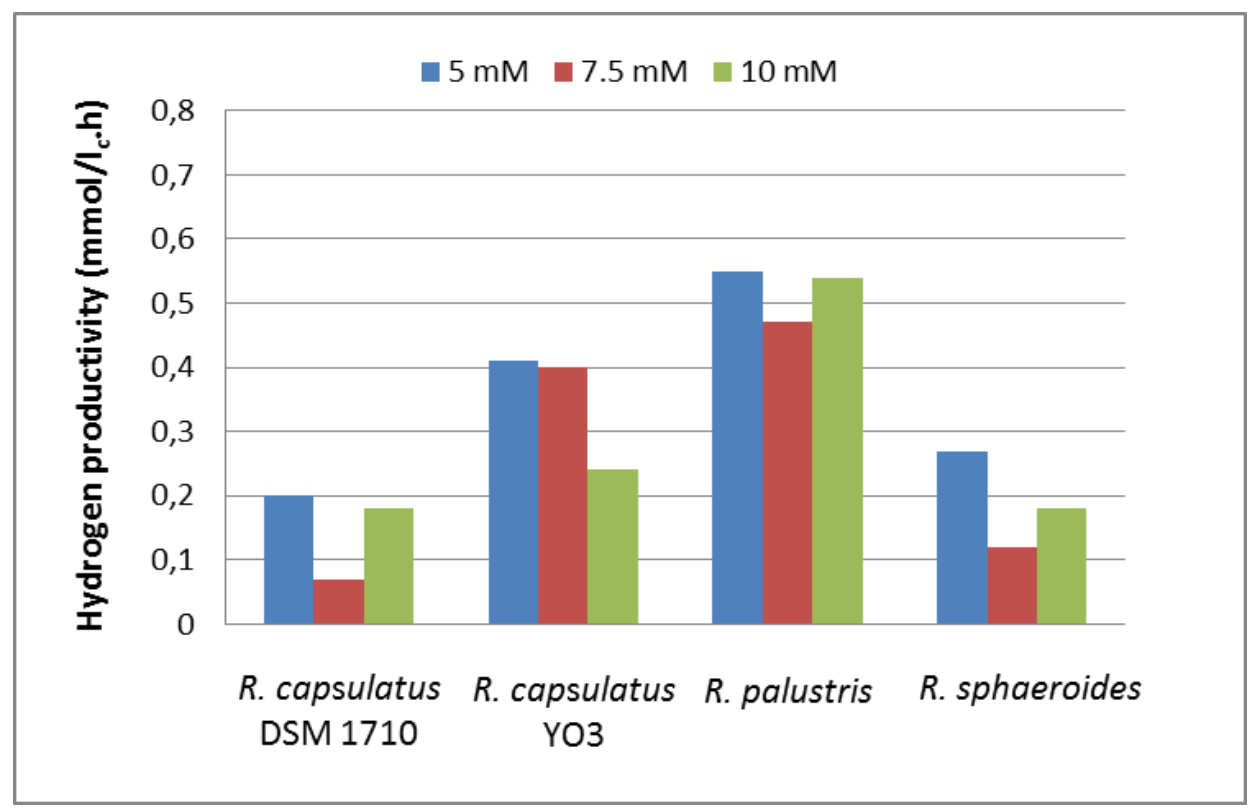

Figure 3.39 The hydrogen productivities of different PNS bacteria on molasses with different sucrose concentrations (5-7.5-10 mM). 


\subsection{Co-cultivation of PNS Bacteria}

The objectives of the co-cultivation studies were improving hydrogen production, bacterial growth and $\mathrm{pH}$ stabilization by PNS bacterial co-cultures in photobioreactors.

In this part of the study different strains of PNS bacteria such as $R$. capsulatus YO3 (Hup ), R. palustris (DSM 127) and $R$. sphaeroides O.U.001 (DSM 5864) were cocultivated for hydrogen production on sucrose $(5 \mathrm{mM})$ for all the photobioreactors. The growth ad hydrogen production parameters were studied with $150 \mathrm{ml}$ photobioreactors with an illumination of 2000-2200 lux, and a temperature of 30-32 ${ }^{\circ} \mathrm{C}$ at cooling incubators.

Table 3.19 Co-cultured bacterial strains.

\begin{tabular}{|c|}
\hline \multicolumn{2}{|c|}{ Co-cultured Bacteria } \\
\hline R. capsulatus YO3 (Hup ${ }^{-}$) and $R$. \\
palustris (DSM 127)
\end{tabular}




\subsubsection{Co-cultivation of $R$. capsulatus YO3 (Hup") and $R$. palustris (DSM 127)}

The bacterial inoculations $5 \%$ from each strain, was done with freshly grown cultures of $R$. capsulatus YO3 (Hup') and $R$. palustris (DSM 127) when their optical density (OD660) reached 2.0. Photobiological hydrogen production was followed in $150 \mathrm{ml}$ PBRs on molasses medium with $5 \mathrm{mM}$ of sucrose.

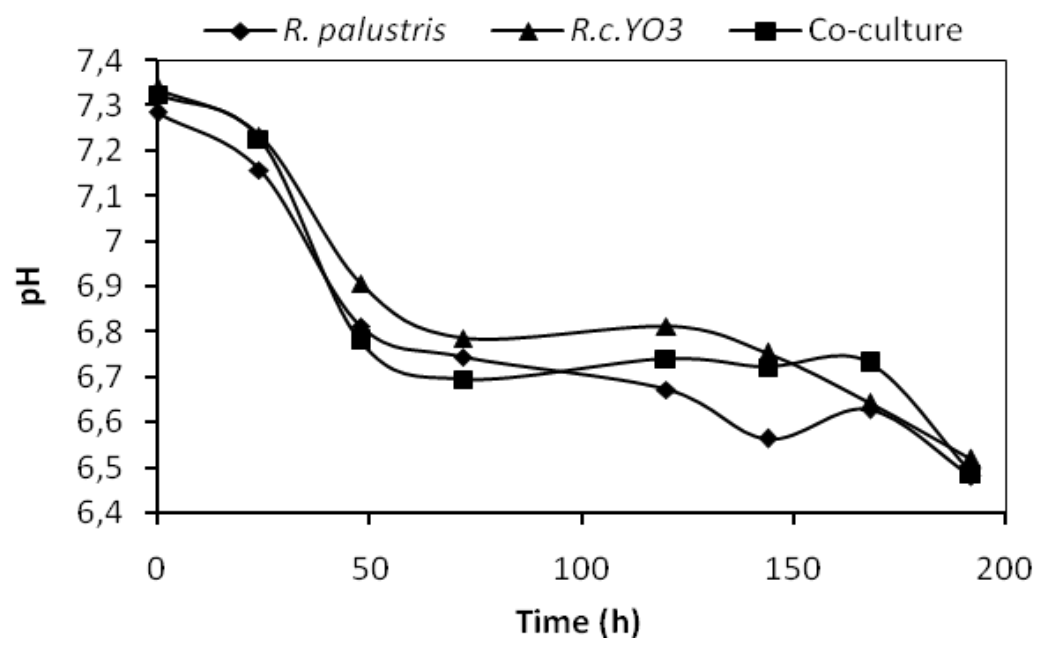

Figure 3.40 The $\mathrm{pH}$ variation in single cell and co-cultures of $R$. capsulatus YO3 (Hup-) and $R$. palustris (DSM 127), during hydrogen production on molasses medium with $5 \mathrm{mM}$ sucrose.

The $\mathrm{pH}$ range was between 6.5-7.3 in both single cell cultures and co-culture of $R$. capsulatus YO3 (Hup ${ }^{-}$) and $R$. palustris (DSM 127). The decline in $\mathrm{pH}$ was observed between 0-48 hours in all the PBRs. The biomass growth of the co-culture showed a more stable profile rather than single cell cultures. The maximum biomass of the single cell cultures and the co-culture were $0.68 \mathrm{gdcw} / \mathrm{l}_{\mathrm{c}}, 0.94 \mathrm{gdcw} / \mathrm{l}_{\mathrm{c}}$, and 0.95 $\mathrm{gdcw} / \mathrm{l}_{\mathrm{c}}$ respectively. The growth showed more fluctuations in the single cell cultures. The pHs and biomass growth (OD) of both single cell cultures and coculture of $R$. capsulatus YO3 (Hup') and R. palustris (DSM 127) were shown in Figure 3.40 and Figure 3.41 respectively. 


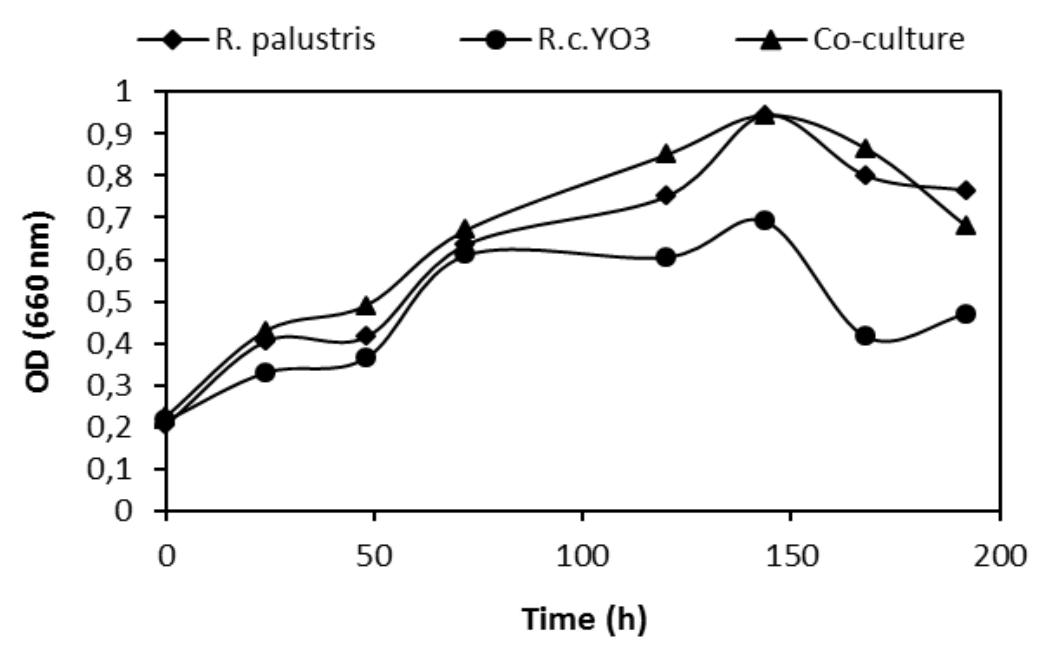

Figure 3.41 The growth of single cell and co-cultures of $R$. capsulatus YO3 (Hup-) and $R$. palustris (DSM 127) on molasses medium with $5 \mathrm{mM}$ sucrose.

The maximum hydrogen production of the co-culture was $0,9181 / 1_{c}$. The cumulative hydrogen production was the greatest $\left(1.731 / l_{\mathrm{c}}\right)$ with the single cell culture of $R$. palustris (DSM 127). The maximum hydrogen was 0,54 in $R$. capsulatus YO3 (Hup ). Given in Figure 3.42 is the cumulative hydrogen production curves in single cell and co-cultures of $R$. capsulatus YO3 (Hup') and R. palustris (DSM 127). 


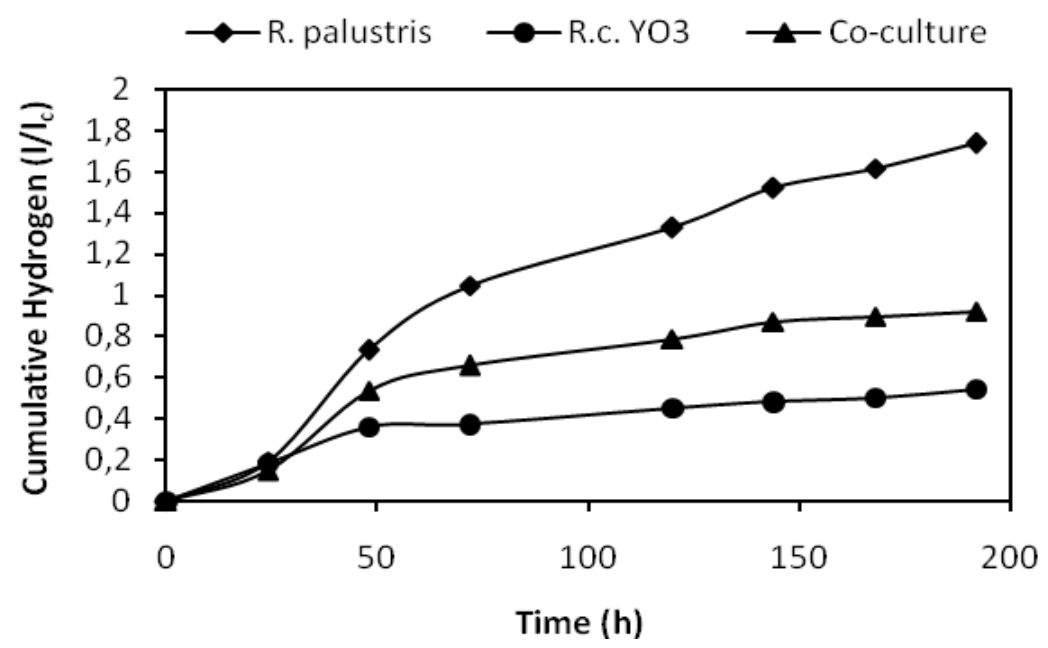

Figure 3.42 The cumulative hydrogen production of single cell and co-cultures of $R$. capsulatus YO3 (Hup ${ }^{-}$) and $R$. palustris (DSM 127) on molasses medium with $5 \mathrm{mM}$ sucrose.

Formic acid, lactic acid and acetic acid were the products of the photofermentation during 192 hours. In the single cell cultures, all of these organic acids were just produced through the operation time. There could be small negligible reductions in their amounts. On the other hand, the concentrations of formic acid, lactic acid and acetic acid raised up for the first 72 hours. After that, the concentrations of the organic acids began to decrease and finish at the end of the process. Shown in Table 3.18 is the concentrations of the organic acids in co-cultivation of R. capsulatus YO3 (Hup) and R. palustris (DSM 127).

The sucrose consumption was achieved as $97.6 \%$ by the co-culture of $R$. capsulatus YO3 (Hup') and R. palustris (DSM 127). The single cell cultures consumed sucrose as $53.3 \%$ and $51.2 \%$ of the concentrations. Table 3.21 indicates the sucrose consumption of the co-cultivation of $R$. capsulatus YO3 (Hup') and $R$. palustris (DSM 127). 
Table 3.20 The concentrations of the organic acids in co-cultivation of $R$. capsulatus YO3 (Hup') and R. palustris (DSM 127).

\begin{tabular}{|c|c|c|c|c|c|c|}
\hline $\begin{array}{c}\text { Hydrogen production } \\
\text { media }\end{array}$ & \multicolumn{2}{|c|}{$R$. palustris } & \multicolumn{2}{|c|}{$R$. capsulatus $\mathrm{YO} 3$} & \multicolumn{2}{c|}{$\begin{array}{c}\text { Co-culture (R. palustris-R. capsulatus } \\
\text { YO3) }\end{array}$} \\
\hline Organic acids & $\begin{array}{c}\mathrm{C}_{0} \\
(\mathrm{mM})\end{array}$ & $\begin{array}{c}\mathrm{C}_{\mathrm{f}} \\
(\mathrm{mM})\end{array}$ & $\begin{array}{c}\mathrm{C}_{0} \\
(\mathrm{mM})\end{array}$ & $\begin{array}{c}\mathrm{C}_{\mathrm{f}} \\
(\mathrm{mM})\end{array}$ & $\mathrm{C}_{0}(\mathrm{mM})$ & $\mathrm{C}_{\mathrm{f}}(\mathrm{mM})$ \\
\hline Acetic acid & 0.583 & 3.068 & 0.531 & 3.466 & 0.913 & 0.481 \\
\hline Formic acid & 1.810 & 10.66 & 1.079 & 6.365 & 2.781 & 0.168 \\
\hline Lactic acid & 0.68 & 2.27 & 0.54 & 1.78 & 0.90 & 0.04 \\
\hline
\end{tabular}

$\mathrm{C}_{0} *$ The initial concentration $(\mathrm{mM})$

$\mathrm{C}_{\mathrm{f}} *$ The final concentration (mM)

Table 3.21 The sucrose consumption (\%) during growth and hydrogen production by single cell and co-cultures of $R$. capsulatus YO3 (Hup-) and $R$. palustris (DSM 127) on molasses medium with $5 \mathrm{mM}$ sucrose.

\begin{tabular}{|l|c|c|c|}
\hline \multicolumn{1}{|c|}{$\begin{array}{c}\text { (PBRs) } \\
\text { Sucrose }(5 \mathrm{mM})\end{array}$} & $\mathrm{C}_{0}(\mathrm{mM})$ & $\mathrm{C}_{\mathrm{f}}(\mathrm{mM})$ & Sucrose consumption (\%) \\
\hline R. palustris & 5.012 & 2.34 & 53.3 \\
\hline R. capsulatus YO3 & 4.98 & 2.43 & 51.2 \\
\hline Co-culture (R. palustris-R. capsulatus YO3) & 5.02 & 0.12 & 97.6 \\
\hline
\end{tabular}


3.6.3 Co-cultivation of $R$. palustris (DSM 127) and $R$. sphaeroides O.U.001 (DSM 5864)

The bacterial inoculation (5\% from each strain) was done with freshly grown cultures of $R$. palustris (DSM 127) and $R$. sphaeroides O.U.001 (DSM 5864) when their optical density (OD660) reached 2.0. Photobiological hydrogen production was followed in $150 \mathrm{ml}$ PBRs on molasses medium with $5 \mathrm{mM}$ of sucrose. The process was continued for 240 hours. The pHs of the PBRs declined through the time. The range of $\mathrm{pH}$ was 7.4-5.5 in all the media (Figure 3.43). The $\mathrm{pH}$ stayed at between 6.0-7.4 in the co-culture whereas drops in $\mathrm{pH}$ was observed mostly in single cell $R$. palustris (DSM 127).

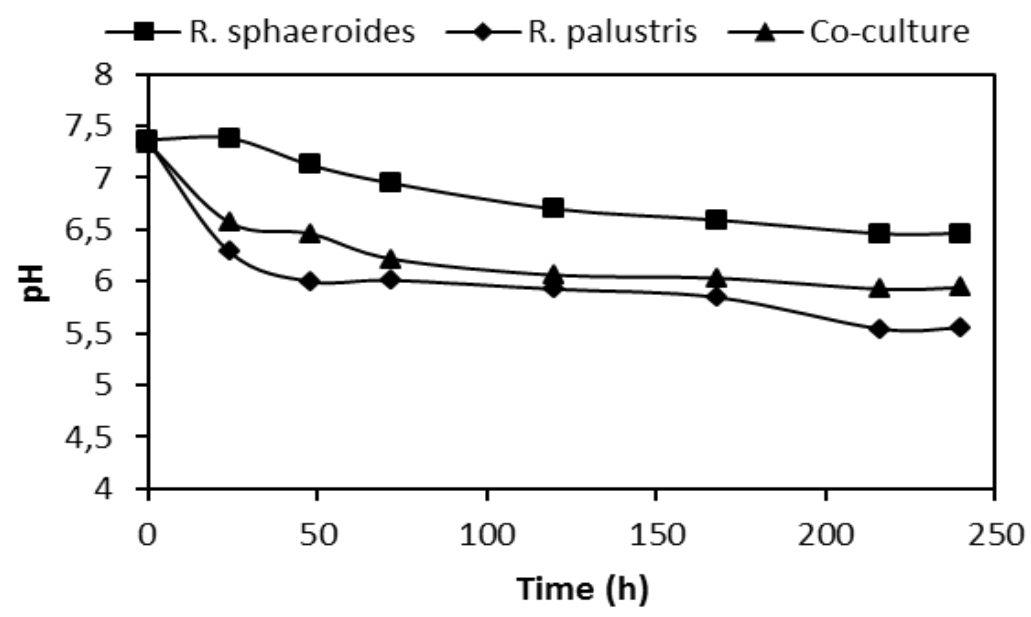

Figure 3.43 The $\mathrm{pH}$ variation in single cell and co-cultures of $R$. sphaeroides O.U.001 (DSM 5864) and R. palustris (DSM 127), during hydrogen production on molasses medium with $5 \mathrm{mM}$ sucrose.

The cell growth was greater in R. sphaeroides O.U.001 (DSM 5864) and co-culture. The maximum biomass was $1.10 \mathrm{gdcw} / \mathrm{l}_{\mathrm{c}}$ and $1.15 \mathrm{gdcw} / \mathrm{l}_{\mathrm{c}}$ respectively. Given in Figure 3.44 is the biomass growth (OD) of single cell and co-cultures of $R$. palustris (DSM 127) and R. sphaeroides O.U.001 (DSM 5864). 
The maximum hydrogen was about the same as $1.191 / 1_{\mathrm{c}}$ in both co-cultivation and single cell $R$. palustris (DSM 127).

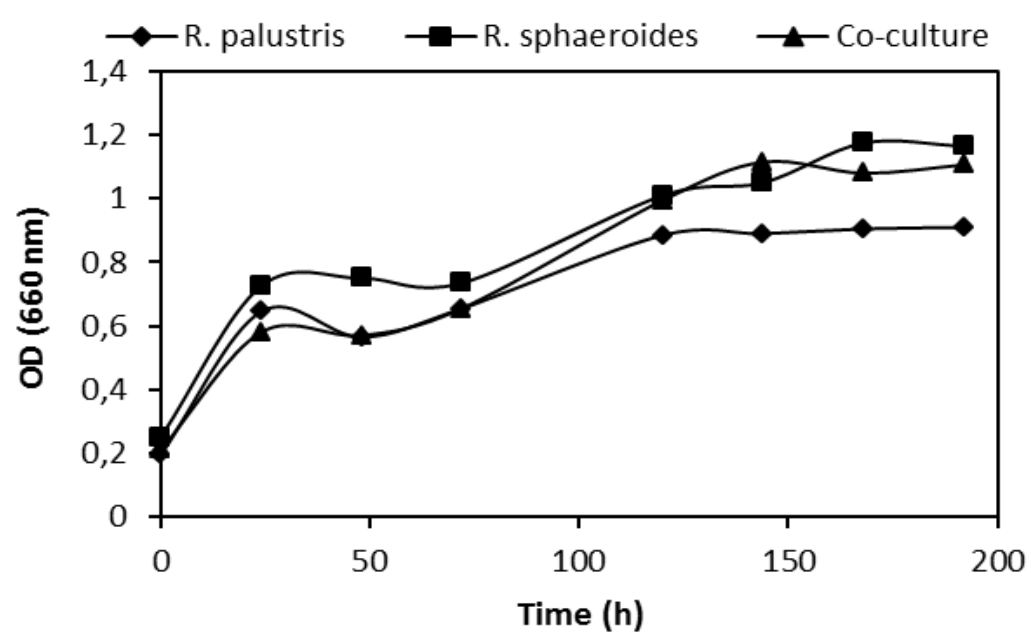

Figure 3.44 The growth of single cell and co-cultures of $R$. sphaeroides O.U.001 (DSM 5864) and R. palustris (DSM 127) on molasses medium with $5 \mathrm{mM}$ sucrose.

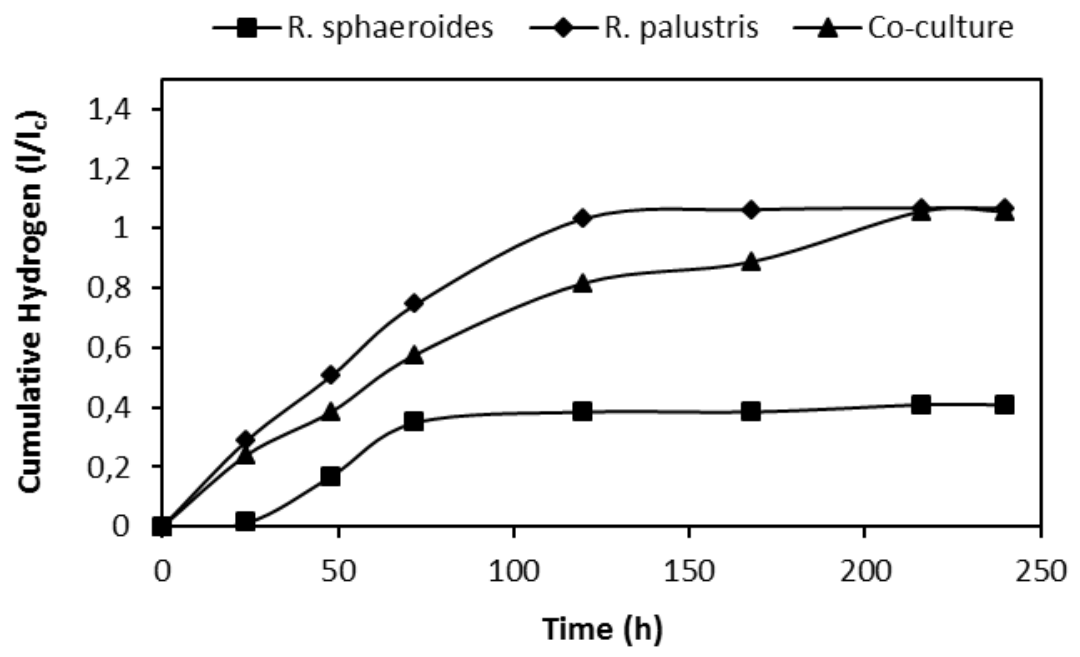


Figure 3.45 The cumulative hydrogen production of single cell and co-cultures of $R$. sphaeroides O.U.001 (DSM 5864) and R. palustris (DSM 127) on molasses medium with $5 \mathrm{mM}$ sucrose.

The production of the formic acid, acetic acid and lactic acid increased through the operation time. Trace amounts of propionic acid was also produced. The production and consumption of organic acids is given in Table 3.22.

Table 3.22 The concentrations of the organic acids in co-cultivation of $R$. palustris (DSM 127) and R. sphaeroides O.U.001 (DSM 5864).

\begin{tabular}{|c|c|c|c|c|c|c|}
\hline $\begin{array}{c}\text { Hydrogen production } \\
\text { media }\end{array}$ & \multicolumn{2}{|c|}{$R$. palustris } & \multicolumn{2}{c|}{$R$ sphaeroides } & \multicolumn{2}{c|}{$\begin{array}{c}\text { Co-culture }(R . \text { palustris- } R . \\
\text { sphaeroides })\end{array}$} \\
\hline Organic acids & $\begin{array}{c}\mathrm{C}_{0} \\
(\mathrm{mM})\end{array}$ & $\begin{array}{c}\mathrm{C}_{\mathrm{f}} \\
(\mathrm{mM})\end{array}$ & $\begin{array}{c}\mathrm{C}_{0} \\
(\mathrm{mM})\end{array}$ & $\begin{array}{c}\mathrm{C}_{\mathrm{f}} \\
(\mathrm{mM})\end{array}$ & $\mathrm{C}_{0}(\mathrm{mM})$ & $\mathrm{C}_{\mathrm{f}}(\mathrm{mM})$ \\
\hline Acetic acid & 0.181 & 7.98 & 0.129 & 1.028 & 0.408 & 5.516 \\
\hline Formic acid & 1.58 & 4.68 & 0.50 & 15.54 & 1.56 & 5.75 \\
\hline Lactic acid & 0.36 & 9.47 & 0.23 & 1.28 & 0.64 & 4.84 \\
\hline
\end{tabular}

The consumption of sucrose (\%) was about same and $50 \%$ by the single cell cultures and the co-culture of $R$. palustris (DSM 127) and R. sphaeroides O.U.001 (DSM 5864). 
Table 3.23 The sucrose consumption (\%) in co-cultivation of $R$. palustris (DSM 127) and R. sphaeroides O.U.001 (DSM 5864).

\begin{tabular}{|l|c|c|c|}
\hline \multicolumn{1}{|c|}{$\begin{array}{c}\text { (PBRs) } \\
\text { Sucrose }(5 \mathrm{mM})\end{array}$} & $\mathrm{C}_{0}(\mathrm{mM})$ & $\mathrm{C}_{\mathrm{f}}(\mathrm{mM})$ & Sucrose consumption (\%) \\
\hline R. palustris & 4.97 & 2.40 & 50.07 \\
\hline R. sphaeroides & 5.10 & 2.48 & 51.3 \\
\hline Co-culture (R. palustris-R. sphaeroides) & 4.89 & 2.53 & 50.07 \\
\hline
\end{tabular}

\subsubsection{Co-cultivation of $R$. capsulatus YO3 (Hup') and $R$. sphaeroides O.U.001 (DSM 5864)}

The bacterial inoculation (5\% from each strain) was done with freshly grown cultures of $R$. capsulatus YO3 (Hup') and $R$. sphaeroides O.U.001 (DSM 5864) when their optical density (OD660) reached 2.0. Photobiological hydrogen production was followed in $150 \mathrm{ml}$ PBRs on molasses medium with $5 \mathrm{mM}$ of sucrose. The process was continued for 240 hours.

The range of $\mathrm{pH}$ was between 7.4-6.0 in all the PBRs. Figure 3.46 shows the $\mathrm{pH}$ changes in co-cultivation of $R$. capsulatus YO3 (Hup') and $R$. sphaeroides O.U.001 (DSM 5864). 


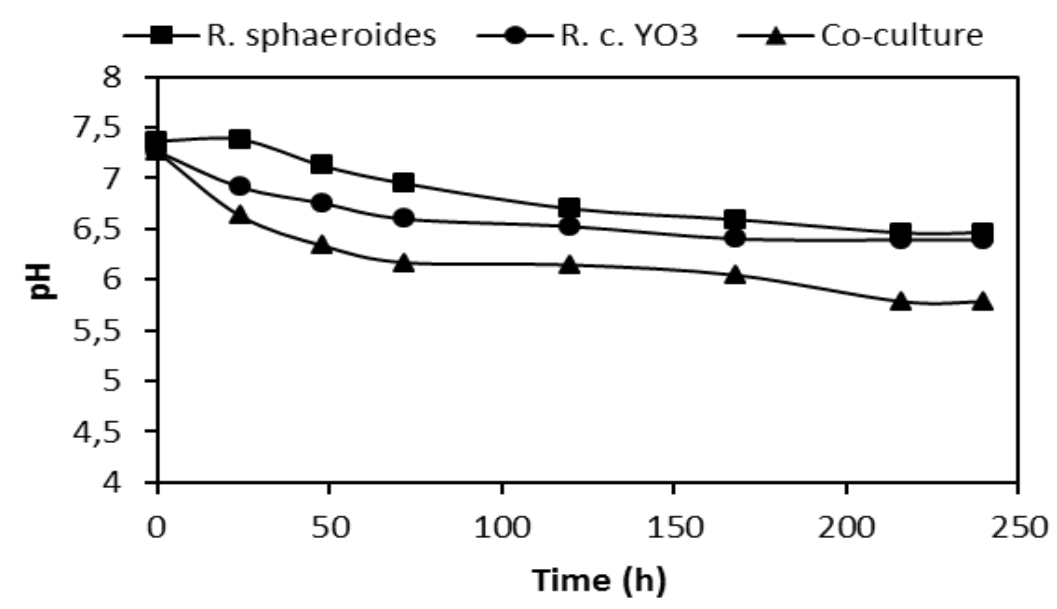

Figure 3.46 The $\mathrm{pH}$ variation in single cell and co-cultures of $R$. capsulatus YO3 (Hup-) and R. sphaeroides O.U.001 (DSM 5864) on molasses medium with $5 \mathrm{mM}$ sucrose.

R. capsulatus YO3 (Hup) had the lowest biomass growth as $0.61 \mathrm{gdcw} / \mathrm{l}_{\mathrm{c}}$. The growth of $R$. sphaeroides O.U.001 (DSM 5864) was the greatest (1.18 gdcw/l $)$ of all the PBRs. Co-culture of these two strains had a maximum growth as $1.02 \mathrm{gdcw} / \mathrm{l}_{\mathrm{c}}$. Figure 3.47 shows the growth curves of single cell and co-cultures of $R$. capsulatus YO3 (Hup') and R. sphaeroides O.U.001 (DSM 5864).

Hydrogen production of the co-culture were promising and the greatest of all the PBRs. The maximum hydrogen was $1.251 / 1_{\mathfrak{c}}, 0.701 / 1_{c}$ and $0.471 / 1_{c}$ in order of coculture, $R$. capsulatus YO3 (Hup ${ }^{-}$) and $R$. sphaeroides O.U.001 (DSM 5864). Given in Figure 3.44 is the cumulative hydrogen production in co-cultivation of $R$. capsulatus YO3 (Hup ${ }^{-}$) and R. sphaeroides O.U.001 (DSM 5864). 


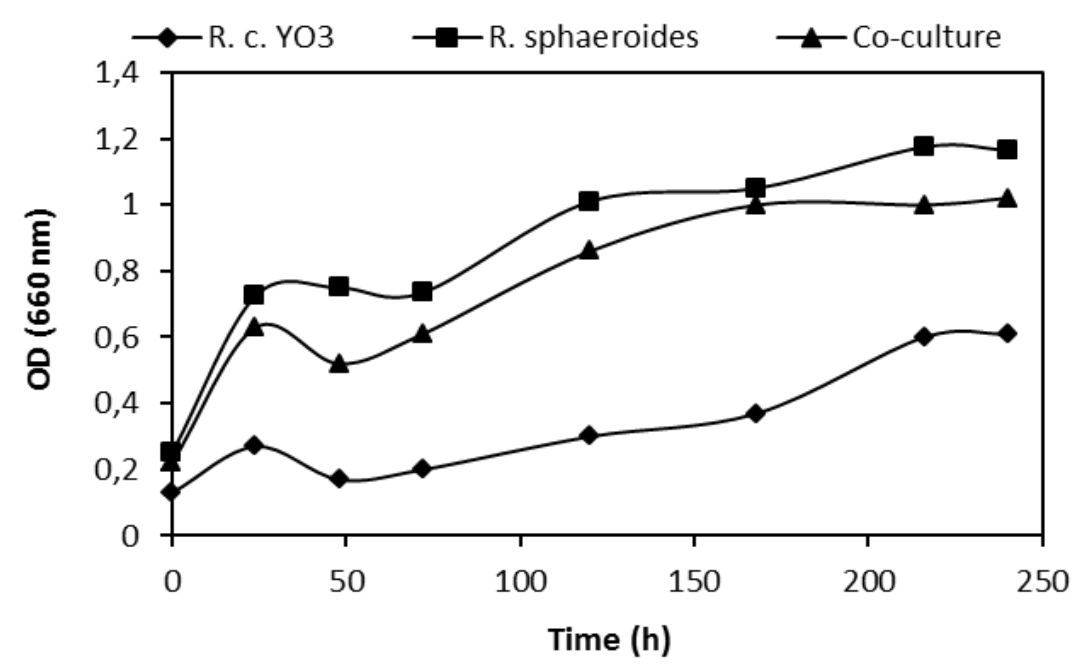

Figure 3.47 The growth of single cell and co-cultures of $R$. capsulatus YO3 (Hup-) and $R$. sphaeroides O.U.001 (DSM 5864) on molasses medium with $5 \mathrm{mM}$ sucrose.

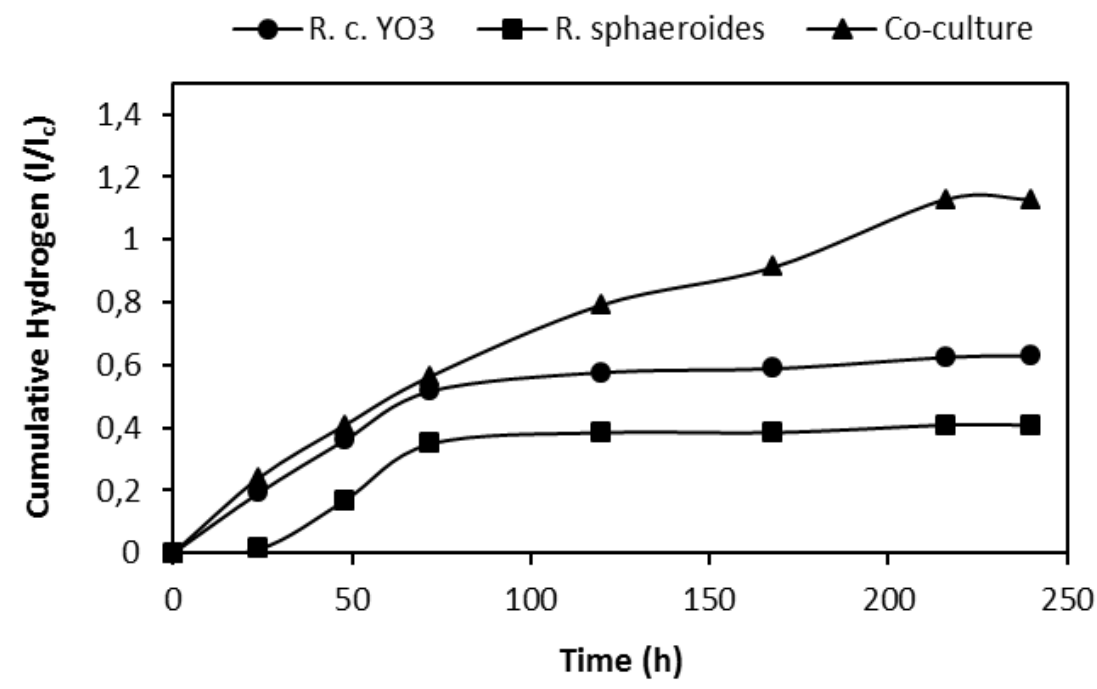

Figure 3.48 The cumulative hydrogen production of single cell and co-cultures of $R$. capsulatus YO3 (Hup-) and R. sphaeroides O.U.001 (DSM 5864) on molasses medium with $5 \mathrm{mM}$ sucrose. 
Formic acid were produced at high amounts especially in single cell cultures. The production of acetic acid was greater in co-culture than the single cell cultures. Propionic acid amount was greater in fermentation medium than lactic acid and butyric acid. Table 3.24 is given for the concentrations of organic acids in cocultivation of $R$. capsulatus YO3 (Hup ${ }^{-}$) and $R$. sphaeroides O.U.001 (DSM 5864).

$50.9 \%$ of the initial sucrose was consumed through 240 hours. R. capsulatus YO3 (Hup ${ }^{-}$) utilized sucrose at the highest rate as 94.9 and shown in Table 3.25.

Table 3.24 The concentrations of the organic acids in co-cultivation of $R$. capsulatus YO3 (Hup') and R. sphaeroides O.U.001 (DSM 5864).

\begin{tabular}{|c|c|c|c|c|c|c|}
\hline $\begin{array}{c}\text { Hydrogen production } \\
\text { media }\end{array}$ & \multicolumn{2}{|c|}{$R$. capsulatus YO3 } & \multicolumn{2}{c|}{$R$ sphaeroides } & \multicolumn{2}{c|}{ Co-culture (R. capsulatus YO3-R. sphaeroides) } \\
\hline Organic products & $\mathrm{C}_{0}(\mathrm{mM})$ & $\mathrm{C}_{\mathrm{f}}(\mathrm{mM})$ & $\mathrm{C}_{0}(\mathrm{mM})$ & $\mathrm{C}_{\mathrm{f}}(\mathrm{mM})$ & $\mathrm{C}_{0}(\mathrm{mM})$ & $\mathrm{C}_{\mathrm{f}}(\mathrm{mM})$ \\
\hline Acetic acid & 0.394 & 4.676 & 0.138 & 1.18 & 1.274 & 8.422 \\
\hline Formic acid & 1.414 & 14.657 & 0.56 & 12.46 & 3.604 & 6.645 \\
\hline Lactic acid & 0.24 & 1.63 & 0.25 & 1.23 & 1.00 & 1.34 \\
\hline
\end{tabular}

Table 3.21 The sucrose consumption (\%) in co-cultivation of $R$. capsulatus YO3 (Hup ${ }^{-}$) and R. sphaeroides O.U.001 (DSM 5864).

\begin{tabular}{|l|c|c|c|}
\hline \multicolumn{1}{|c|}{$\begin{array}{c}\text { (PBRs) } \\
\text { Sucrose }(5 \mathrm{mM})\end{array}$} & $\mathrm{C}_{0}(\mathrm{mM})$ & $\mathrm{C}_{\mathrm{f}}(\mathrm{mM})$ & Sucrose consumption (\%) \\
\hline R. capsulatus YO3 & 4.55 & 0.23 & 94.9 \\
\hline$R$. sphaeroides & 5.08 & 2.4 & 52.7 \\
\hline Co-culture (R. capsulatus YO3-R. sphaeroides) & 5.120 & 2.512 & 50.9 \\
\hline
\end{tabular}


3.6.4 Mixed-cultures of $R$. capsulatus YO3 (Hup), $R$. palustris (DSM 127) and $R$. sphaeroides O.U.001 (DSM 5864)

The bacterial inoculum (3.33\% from each strains) was done with freshly grown cultures of $R$. capsulatus YO3 (Hup ${ }^{-}$), $R$. palustris (DSM 127) and $R$. sphaeroides O.U.001 (DSM 5864) when their optical density (OD660) reached 2.0. Photobiological hydrogen production was followed in $150 \mathrm{ml}$ PBRs on molasses medium with $5 \mathrm{mM}$ of sucrose. The process was continued for 240 hours.

The $\mathrm{pH}$ of the multiple-culture decreases in a rapid way during the process. The change of $\mathrm{pH}$ is given in Figure 3.49. The maximum biomass growth was $1.03 \mathrm{gdcw} /$ $1_{c}$ and the cumulative hydrogen production was $1.021 / 1_{c}$. The hydrogen production resembled a proportional relation with the growth curve. Figure 3.50 shows the hydrogen production and biomass (OD) versus time.

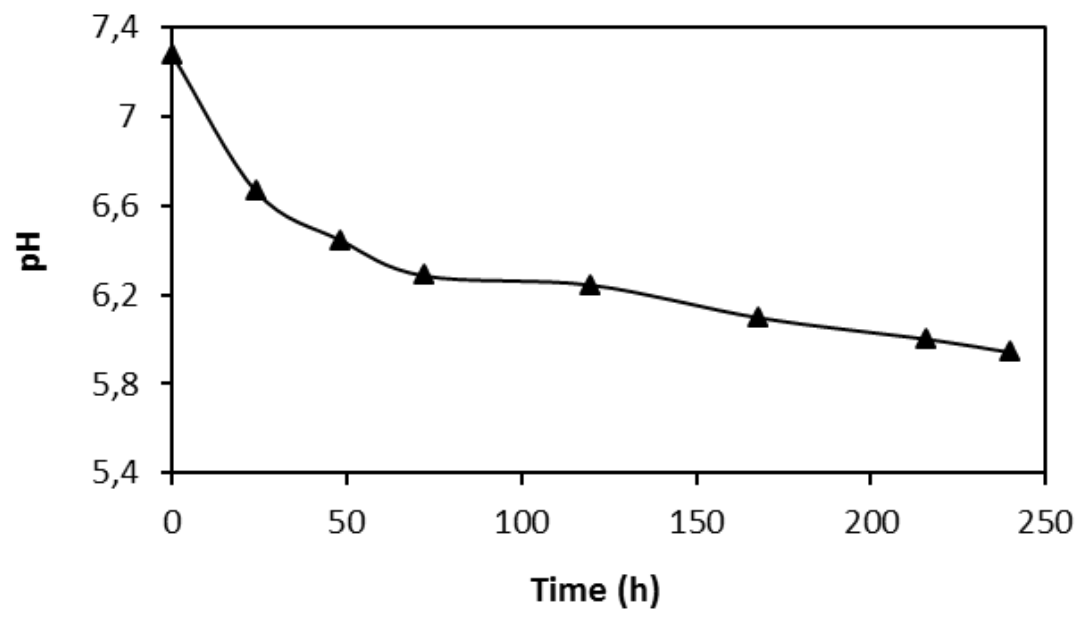

Figure 3.49 The changes of $\mathrm{pH}$ in mixed-cultures of $R$. capsulatus YO3 (Hup-), $R$. palustris (DSM 127) and $R$. sphaeroides O.U.001 (DSM 5864) on molasses medium with $5 \mathrm{mM}$ sucrose. 


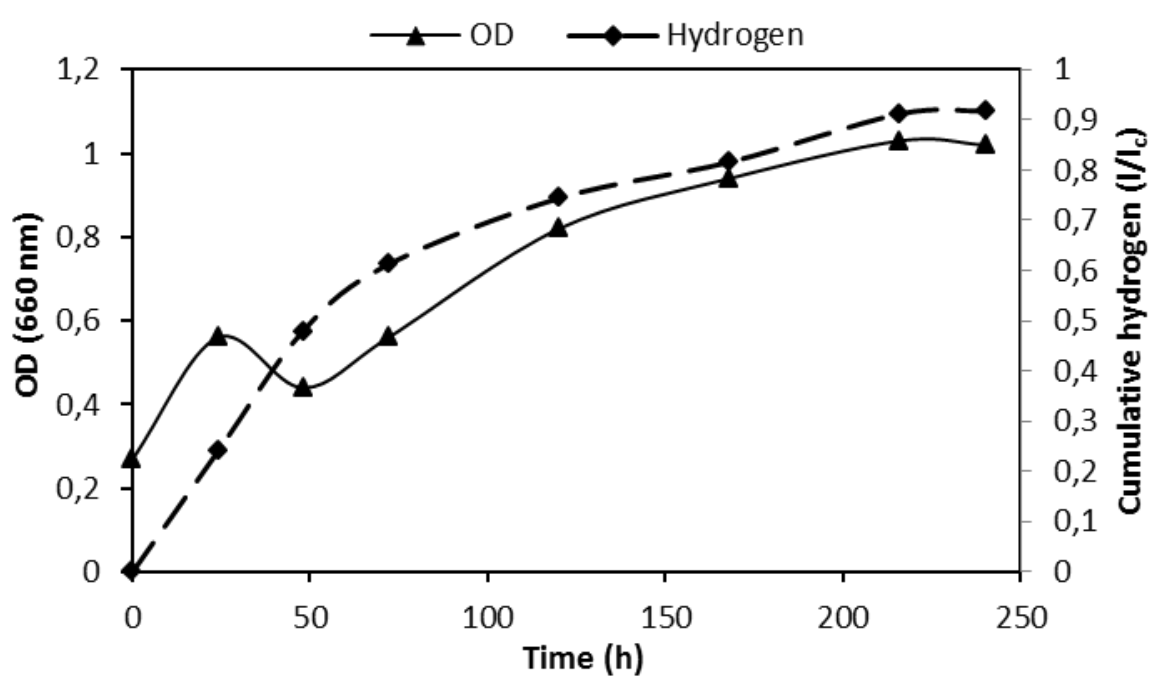

Figure 3.50 The cumulative hydrogen production and growth curves in mixed-culture of $R$. capsulatus YO3 (Hup-), R. palustris (DSM 127) and R. sphaeroides O.U.001 (DSM 5864).

The concentrations of acetic acid, formic acid and lactic acid increased at high amounts through the 192 hours time duration. The consumption of the organic acids could occur but the culture metabolism generally shifted in production mode. Table 3.25 and 3.26 indicate the concentrations of the organic acids and sucrose consumption by $R$. capsulatus YO3 (Hup), $R$. palustris (DSM 127) and $R$. sphaeroides O.U.001 (DSM 5864) respectively. 
Table 3.25 The concentrations of the organic acids in mixed-culture of $R$. capsulatus YO3 (Hup'), R. palustris (DSM 127) and R. sphaeroides O.U.001 (DSM 5864).

\begin{tabular}{|c|c|c|}
\hline Hydrogen production media & Multi-culture (R. capsulatus YO3- $R$. palustris- $R$. sphaeroides) \\
\hline Organic acids & $\mathrm{C}_{0}(\mathrm{mM})$ & $\mathrm{C}_{\mathrm{f}}(\mathrm{mM})$ \\
\hline Acetic acid & 1.12 & 6.45 \\
\hline Formic acid & 3.93 & 11.09 \\
\hline Lactic acid & 0.99 & 12.84 \\
\hline
\end{tabular}

Table 3.26 The sucrose consumption (\%) in mixed-culture of $R$. capsulatus YO3 (Hup'), R. palustris (DSM 127) and R. sphaeroides O.U.001 (DSM 5864).

\begin{tabular}{|c|c|c|c|}
\hline (PBRs) Sucrose $(5 \mathrm{mM})$ & $\mathrm{C}_{0}(\mathrm{mM})$ & $\mathrm{C}_{\mathrm{f}}(\mathrm{mM})$ & Sucrose consumption (\%) \\
\hline Co-culture (R. capsulatus YO3- R. palustris- R. sphaeroides) & 4.957 & 2.484 & 50 \\
\hline
\end{tabular}

The maximum growth was observed as $1.15 \mathrm{OD}$ at $660 \mathrm{~nm}$ in co-cultivation of $R$. sphaeroides O.U.001 (DSM 5864) and R. palustris (DSM 127). The $\mathrm{pH}$ range of the co-cultures were between 6.0-7.4. The pHs of the all co-cultures decreased from ana initial $\mathrm{pH}$ of $7.4 \pm 1.0$.

The cumulative hydrogen production was the highest with the co-cultivation of $R$. capsulatus YO3 and R. sphaeroides O.U.001 (DSM 5864) as $8.37 \mathrm{mmol} / \mathrm{H}_{2}$ for 240 hours photofermentation time. Table 3.23 is given for total hydrogen production as mmol hydrogen.

The $\mathrm{pH}$ range of the same culture was between 6.0-7.4. The maximum biomass growth was $1.02 \mathrm{gdcw} / \mathrm{l}_{\mathrm{c}}$. The substrate conversion efficiencies and hydrogen 
productivities were the greatest with the co-culture of $R$. sphaeroides O.U.001 (DSM 5864) and $R$. palustris (DSM 127).

The highest percentage of sucrose consumption was of $97.6 \%$ with the co-culture of R. capsulatus YO3 (Hup') and R. sphaeroides O.U.001 (DSM 5864). The other cocultures and multiple cultivation had a consumption rate of approximately $50.0 \%$.

Light conversion efficiency was maximal and $0.19 \%$ in co-cultivation of $R$. sphaeroides O.U.001 (DSM 5864) with R. capsulatus YO3 (Hup'). The light conversion efficiencies of different co-cultures are given in Table 3.24.

Table 3.23 Duration of the processes and total hydrogen production of different PNS bacteria in $150 \mathrm{ml}$ bioreactors.

\begin{tabular}{|c|c|c|}
\hline Microorganisms & Duration of process $(\mathrm{h})$ & 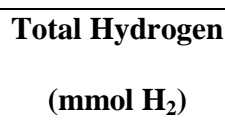 \\
\hline R. capsulatus YO3 & 240 & 4.67 \\
\hline R. palustris & 192 & 11.5 \\
\hline R. sphaeroides & 240 & 3.0 \\
\hline R. capsulatus $\mathrm{YO} 3$ and $R$. palustris & 192 & 6.13 \\
\hline$R$. sphaeroides and $R$. palustris & 240 & 7.83 \\
\hline R. capsulatus $\mathrm{YO} 3$ and $R$. sphaeroides & 240 & 8.37 \\
\hline R. capsulatus YO3, R. sphaeroides and $R$. palustris & 240 & 6.81 \\
\hline
\end{tabular}


Table 3.24 Summary of the co-cultivation of different PNS bacteria on $5 \mathrm{mM}$ sucrose from molasses.

\begin{tabular}{|c|c|c|c|c|c|}
\hline Microorganisms & $\begin{array}{l}\text { Biomass } \\
\left(\mathrm{gdcw} / \mathrm{I}_{\mathrm{c}}\right)\end{array}$ & $\begin{array}{c}\text { Hydrogen } \\
\text { productivity } \\
\left(\mathrm{mmol} / \mathrm{I}_{\mathrm{c}} \cdot \mathrm{h}\right)\end{array}$ & $\begin{array}{c}\text { Substrate } \\
\text { conversion } \\
\text { efficiency }(\%)\end{array}$ & $\begin{array}{c}\text { Sucrose } \\
\text { consumption } \\
(\%)\end{array}$ & $\begin{array}{c}\text { Light } \\
\text { conversion } \\
\text { efficiency }(\%)\end{array}$ \\
\hline $\begin{array}{c}\text { R. capsulatus } \\
\text { YO3 }\end{array}$ & 0.61 & 0.35 & 30.2 & 94.9 & 0.10 \\
\hline R. palustris & 0.94 & 1.07 & 42.5 & 53.3 & 0.32 \\
\hline R. sphaeroides & 1.15 & 0.28 & 32.1 & 51.3 & 0.06 \\
\hline $\begin{array}{c}\text { R. capsulatus } \\
\text { YO3 and } R \text {. } \\
\text { palustris }\end{array}$ & 0.95 & 0.57 & 34.0 & 97.6 & 0.17 \\
\hline $\begin{array}{l}R . \text { sphaeroides } \\
\text { and R. palustris }\end{array}$ & 1.10 & 1.0 & 92.0 & 50.0 & 0.18 \\
\hline $\begin{array}{l}\text { R. capsulatus } \\
\text { YO3 and } R . \\
\text { sphaeroides }\end{array}$ & 1.02 & 0.40 & 76.2 & 50.09 & 0.19 \\
\hline $\begin{array}{l}\text { R. capsulatus } \\
\text { YO3, } R \text {. } \\
\text { sphaeroides and } \\
\text { R. palustris }\end{array}$ & 1.03 & 0.42 & 76.8 & 50.0 & 0.15 \\
\hline
\end{tabular}

\section{Efficiency of the Hydrogen Production}

For practical application of hydrogen production from molasses, a global cost estimation has been done only considering the price of molasses and the efficiency of hydrogen production for each strain was given below;

Total molasses production of Ankara Sugar Factory in a year $=19520$ tons $=$ $19520.000 \mathrm{~kg}$

The cost of molasses $=1 \mathrm{~kg}=0.279 \mathrm{TL}$

The price of total molasses $=5.446 .080 \mathrm{TL}$

Energy content of hydrogen $=142.000 \mathrm{kj} / \mathrm{kg}$ 
Total estimated hydrogen production in a year from sugar beet molasses;

Using R. capsulatus $(\mathrm{DSM} 1710)=0.00222 \mathrm{~g} \mathrm{H}_{2} / 1.5 \mathrm{~g}$ molasses $=28.8 \times 10^{6} \mathrm{~g} \mathrm{H}_{2} /$ g molasses $=4.08 \times 10^{9} \mathrm{kj} / \mathrm{kg} \mathrm{H}$

R. capsulatus YO3 $\left(\mathrm{Hup}^{-}\right)=0.00138 \mathrm{~g} \mathrm{H}_{2} / 1.5 \mathrm{~g}$ molasses $=17.9 \times 10^{6} \mathrm{~g} \mathrm{H}_{2} / \mathrm{g}$ molasses $=2.51 \times 10^{9} \mathrm{kj} / \mathrm{kg} \mathrm{H}$

R. palustris $\left(\right.$ DSM 127) $=0.0062 \mathrm{~g} \mathrm{H}_{2} / 1.5 \mathrm{~g}$ molasses $=80.6 \times 10^{6} \mathrm{~g} \mathrm{H}_{2} / \mathrm{g}$ molasses $=11.4 \times 10^{9} \mathrm{kj} / \mathrm{kg} \mathrm{H}_{2}$

R. sphaeroides O.U.001 $=0.00268 \mathrm{~g} \mathrm{H}_{2} / 1.5 \mathrm{~g}$ molasses $=34.8 \times 10^{6} \mathrm{~g} \mathrm{H}_{2} / \mathrm{g}$ molasses $=4.94 \times 10^{9} \mathrm{kj} / \mathrm{kg} \mathrm{H}$

Co-cultivation of $R$. palustris (DSM 127) and $R$. sphaeroides O.U.001 $=0.016 \mathrm{~g}$ $\mathrm{H}_{2} / 2.26 \mathrm{~g}$ molasses $=13.8 \times 10^{7} \mathrm{~g} \mathrm{H}_{2} / \mathrm{g}$ molasses $=1.9 \times 10^{10} \mathrm{kj} / \mathrm{kg} \mathrm{H}$. 


\section{CHAPTER 4}

\section{CONCLUSIONS}

The growth and hydrogen production was performed by PNS bacteria with the utilization of sucrose in defined and diluted-molasses media in all photobioreactors through direct photofermentation. The concluded remarks were summarized below.

Sucrose is a good substrate especially for the growth of purple non-sulphur bacteria. The PNS bacteria have grown better in sucrose media than acetate media.

Molasses can also be considered as a potential source for bacterial growth and hydrogen production by PNS bacteria.

Hydrogen production capacities depend on the concentration of sucrose, $\mathrm{pH}$ and type of PNS bacteria.

Acetic acid, formic acid, lactic acid, propionic acid and butyric acid are end products of the photofermentation of PNS bacteria on sucrose and molasses. The amount and type of the organic acids varied between the strains of PNS bacteria. All of these organic substrates can be used for the bacteria while they are producing simultaneously. Propionic acid is produced mostly by $R$. capsulatus YO3 (Hup') in both single cell and co-cultures.

Formic acid was produced predominantly at higher amounts through the utilization of sucrose. 
The intermediate products of the sucrose and organic acids decreased the pHs of hydrogen production media. This may inhibit or prevent hydrogen production metabolism of photosynthetic bacteria.

The evolved gases in PBRs was mostly hydrogen in a range of 70-90\%. The rest was carbondioxide. Carbondioxide production was observed mainly after the third day of the photofermentation in $50 \mathrm{ml}$ bioreactors. The amount of produced carbondioxide was about $5-10 \%$ of the total gas in $150 \mathrm{ml}$ co-cultured bioreactors.

Rhodopseudomonas palustris (DSM 127) was found to be the most suitable PNS bacteria for hydrogen production.

The co-cultivation of Rhodopseudomonas palustris (DSM 127) and R. sphaeroides O.U.001 was more suitable for hydrogen production from molasses comparing with single cell cultures. 


\section{REFERENCES}

Akkerman, I., Janssen, M., Rocha, J., Wijffels, R.H., (y2002), "Photobiological hydrogen production: photochemical efficiency and bioreactor design", International Journal of Hydrogen Energy, 27, 1195-1208, 2002.

Androga DD., (2009) "Biological hydrogen production on acetate in continuous panel photobioreactors using Rhodobacter capsulatus. Turkey: Chemical Engineering Department of Middle East Technical University; 2009, Master of Science thesis.

Androga DD, Özgür, E., Ozturk, Y., Gunduz U, Eroglu, I., "Factors affecting the longterm stability of biomass and hydrogen productivity in outdoor photofermentation.”, Int J Hydrogen Energy; 2011.

Asada, Y., Tokumoto, M., Aihara, Y., Oku, M., Ishimi, K., Wakayama, T., (2006), "Hydrogen production by co-cultures of Lactobacillus and a photosynthetic bacterium, Rhodobacter sphaeroides RV. Int Journal of Hydrogen Energy, 2006;31:1509-13

Avcioglu, S.G., Ozgur, E., Eroglu, I., Yucel, M., Gunduz, U., (2011), “Biohydrogen production in an outdoor panel photobioreactor on dark fermentation effluent of molasses”, International Journal of Hydrogen Energy, 36:11360-11368.

Basak, N., Das, D., 2007, “The prospect of purple non-sulfur (PNS) photosynthetic bacteria for hydrogen production: the present state of the art", World J. Microbiol. Biotechnol., 23:31-42.

Biebl, H., Pfennig, N., (1981), "Isolation of Members of the Family Rhodosprillaceae.”, In: The prokaryotes. Editors: Starr, M.P., Stolp, H., Trüper, H.G., Balows, A., Schlegel, H.G., New York: Springer-Verlag, 267-273. 
Bolliger, R., Zürrer, H., Bachofen, R., (1985), "Photoproduction of molecular hydrogen from wastewater of a sugar refinery by photosynthetic bacteria" Appl. Microbiol. Biotechnology., 23 (1985), pp. 147-151.

Chen, C.C., Lin, C.Y., Chang, J.S., (2001), "Kinetics of hydrogen production with continuous anaerobic cultures utilizing sucrose as the limiting substrate", Appl Microbiol Biotechnol, 57:56-64.

Chu, C.Y., Wu, S.Y., Hsieh, P.C., Lin, C.Y., (2011), "Biohydrogen production from immobilized cells and suspended sludge systems with condensed molasses fermentation solubles", International Journal of Hydrogen Energy, 36:14078-14085.

Claassen, P.A.M., Vrije, T., 2006, "'Non-thermal Production of Pure Hydrogen from Biomass: HYVOLUTION', Int. Journal of Hydrogen Energy, 31: 1416 - 1423.

Das, D., Veziroglu, TN., (2001), "Hydrogen production by biological processes: a survey of literatre. International Journal of Hydrogen Energy, 26:13-28.

Eroglu, I., Kadir, A., Gunduz, U., Yucel, M., Turker, L., (1999), "Substrate consumption rates for hydrogen production by Rhodobacter sphaeroides in a column photobioreactor", Journal of Biotechnology, 70: 103-113.

Eroglu, E., Gündüz, U., Yücel, M., Türker, L., Eroglu, I., (2004), ’Photobiological hydrogen production by using olive mill wastewater as a sole substrate source", International Journal of Hydrogen Energy 29 (2004) 163 - 171.

Eroğlu, I., Tabanoğlu, A., Gündüz, U., Eroğlu, E., Yücel, M., 2008, “Hydrogen production by Rhodobacter sphaeroides O.U.001 in a flat plate solar bioreactor", International Journal of Hydrogen Energy, 33:531-541

Fang, HHP., Zhu, HG., Zhang, T., (2006), "Phototrophic hydrogen production from glucose by pure and co-cultures of Clostridium butyricum and Rhodobacter sphaeroides. International Journal of Hydrogen Energy, 31 (2006) 2223:30. 
Fascetti, E., Todini, O., "Rhodobacter sphaeroides RV cultivation and hydrogen production in a one- and two-stage chemostat". Appl. Microbiol Biotechnology 1995;44:300-305.

Gaffron, H., Rubin, J., (1992), "Fermentative and Photochemical Production of Hydrogen by Algae”, J. Gen. Phyiology, 26:219-40.

Hallenbeck, P.C., Benemann, J.R., (2002), "Biological hydrogen production; fundamentals and limiting proceses", International Journal of Hydrogen Energy, 27:1185-1193.

Hussy, I., Hawkes, F.R., Dinsdale, R., Hawkes D.L., (2005), “Continuous fermentative hydrogen production from sucrose and sugarbeet", International Journal of Hydrogen Energy, 2005; 30:471-483.

Hustede, E., Steinbiichel, A., Schlegel, H.G., (1993), "Relationship between the photoproduction of hydrogen and the accumulation of PHB in non-sulphur purple bacteria”, Appl Microbiol Biotechnol, 39:87-93.

Kapdan, I.K., Kargi, F., 2006, "Bio-hydrogen production from waste materials", Enzyme and Microbial Technology, 38:569-582

Koku, H., (2001), "Hydrogen Metabolism and Factors Affecting Hydrogen Production in Rhodobacter sphaeroides", MSc. Thesis in Chemical Engineering, Middle East Technical University, Ankara, Turkey.

Koku, H., Eroğlu, I., Gunduz, U., Yucel, M., Turker, L., (2002), “Aspects of the Metabolism of Hydrogen Production by Rhodobacter sphaeroides', Int. J. Hydrogen Energy, 2:1325-1329. 
Lang, FS., and Oesterhelt, D., (1989) "Microaerophilic growth and induction of the photosynthetic reaction center in Rhodopseudomonas viridis" Journal of Bacteriology. 1989 May; 171(5): 2827-2834.

Larimer, F.W., Chain, P., Hauser, L., Lamerdin, J., Malfatti, S., Do, L., Land, M.L., Pelletier, D.A., Beatty, J.T., Lang, A.S., Tabita, F.R., Gibson, J.L., Hanson, T.E., Bobst, C., Torres, J.L.T.Y., Peres, C., Harrison, F.H., Gibson, J., Harwood, C.S., "Complete genome sequence of the metabolically versatile photosynthetic bacterium Rhodopseudomonas palustris Nature Biotechnology 22, 55 - 61 (2003).

Li, Y.F., Shu, Z., Chen, H., Di, X.Y, (2011), "The operation characteristics of biohydrogen production in continuous stirred tank reactor with molasses", Advanced Materials Research, 152-153:613-618.

Melis, A., (2002), "Green alga hydrogen production: progress, challanges and prospects", 2002, 27:1217-1228.

Miyake, J., Mao XY, Kawamura, S., (1984), "Hydrogen photoproduction from glucose by a co-culture of a photosynthetic bacteria and Clostridium butyricum. Journal of Fermentation Technology 1984;62(6):531-5.

Miyake, J., Kawamura, S., (1987), "Efficiency of Light Energy Conversion to Hydrogen by Photosynthetic Bacteria Rhodobacter sphaeroides', Int. J. Hydrogen Energy, 12:147-9.

Nandi, R., Sengupta S., (1998), "Microbial production of hydrogen: an overview", Critical Rev Microbiol 1998;24(1):61-84.

Nath, K., and Das, Debabrata., (2009), "Effect of light intensity and initial pH during hydrogen production by an integrated dark and photofermentation process". International Journal of Hydrogen Energy, 34, (2009) 7497-7501. 
Ogden, J. M., (1999), "Prospects for Building a Hydrogen Energy Infrastructure," chapter in Annual Review of Energy and the Environment, vol. 24, pp. 227-79, 1999. Olbrich, H., (1963), "Molasses”, Fermentation Technologist, Institut für Zuckerindustrie, Berlin (Germany), Published by Biotechnologie-Kempe GmbH (2006)

Özgür, E., Uyar, B., Öztürk, Y., Yücel, M., Gündüz, U., Eroğlu, İ., 2009, "Biohydrogen Production by Rhodobacter capsulatus on Acetate at Fluctuating Temperatures", Resources, Conservation and Recyling, 2147, 5.

Özgür, E., Mars, A.E., Peksel, B., Louwerse A., Yücel, M., Gündüz, U., Classen, P.A.M., Eroğlu, I., (2010), "Biohydrogen production from beet molasses by sequential dark and photofermentation". International Journal of Hydrogen Energy., 35 (2010) 511-517.

Özkan, E., Uyar, B., Ozgur, E., Yucel, M., Eroglu, I., Gunduz, U., (2011), "Photofermentative hydrogen production using dark fermentation effluent of sugar beet thick juice" doi:10.1016/j.ijhydene.2011.06.035 (2011):1-6

Öztürk Y., Yücel M., Daldal F., Mandacı S., Gündüz U., Türker L., Eroglu I., 2006, "Hydrogen Production by using Rhodobacter capsulatus Mutants with Genetically Modified Electron Transfer Chains”, Int. J. Hydrogen Energy, 31:1545-52.

Pellerin, N.B., and Gest, H., (1983), "Diagnostic Features of the Photosynthetic Bacterium Rhodopseudomonas sphaeroides", Current Microbiology, 9: 339-344. Ren, N., Li, J., Li, B., Wang, Y., Liu, S., (2005), ”Biohydrogen production from molasses by anaerobic fermentation with a pilot-scale bioreactor system", International Journal of Hydrogen Energy, 2006; 31:2147-2157. 
Pilavachi, P.A., Chatzipanagi, A.I., Spyropoulou, A.I., (2009), "Evaluation of hydrogen production methods using the analytic hierarchy process" , International Journal of Hydrogen Energy, 2009; 34:5294-5303.

Qu, Y.Y., Guo, W.Q., Ding, J., Ren, N.Q., (2011), "Feasibility of hydrogen production by a continuous two stage (dark/dark) fermentation system", Advanced Materials Research, 374-377:1000-1004.

Sevinç, P., 2010, “ Kinetic analyses of the effects of temperature and light intensity on growth, hydrogen production and organic acid utilization by Rhodobacter capsulatus", M. Sc. Thesis in Biotechnology Engineering Department, Middle East Technical University, Ankara, Turkey.

Sunita, M., Mitra, C.K., (1993), "Photoproduction of hydrogen by photosynthetic bacteria from sewage and wastewater Journal of Biosci., 18 (1993), pp. 155-160.

Tanisho, S., and Ishiwata, Y., (1994) "Continuous hydrogen production from molasses by the bacterium Enterobacter aerogenes". International Journal of Hydrogen Energy, 1994:19(10):807-12.

Tao, Y., Chen, Y., Wu,Y., He, Y., Zhou, Z., (2007), "High hydrogen yield from a two-step process of dark- and photo-fermentation of sucrose”, International Journal of Hydrogen Energy, 32:200-206.

Türkarslan, S., Yigit, D.Ö., Aslan, K., Eroglu, I., Gündüz U., (1998), "Photobiological hydrogen production by Rhodobacter sphaeroides O.U.001 by utilization of waste water from milk industry. O.R. Zaborsky (Ed.), Biohydrogen, Plenum Press, New York (1998), pp. 151-156. 
Uyar, B., (2008), "Hydrogen Production by Microorganisms in Solar Bioreactor", Ph.D. Thesis in Biotechnology Engineering Department, Middle East Technical University, Ankara, Turkey

Uyar, B., Schumacher, M., Gebicki, J., Modigell, M., (2009), "Photoproduction of hydrogen by Rhodobacter capsulatus from thermophilic fermentation effluent". Bioprocess and Biosystems Engineering 2009;32:603-606.

V. B. D. Skerman, V. McGowan, and P. H. A. Sneath., (1980). Approved lists of bacterial names. Int. J. Syst. Bacteriol. 30, 225-420 (1980).

Vignais, P.M., Colbeau, A., Willison, J.C., Jouanneau, Y., (1985), “Hydrogenase, Nitrogenase, and Hydrogen Metabolism in Photosynthetic Bacteria", Adv. Microbial Phys., 26: 154-234.

Wang, B., Li, Y., Zhu, L., Gao, S., Cao, L., Bai, X., (2011), "The artificial manipulation of the start-up and operation for biological hydrogen production reactor", Taiyangreng Xuebao / Acta Energiae Solaris Sinica, 32: 1106-1110.

Yetis M., Gündüz U., Eroglu I., Yücel M., Türker L., 2000 "Photoproduction of Hydrogen from Sugar Refinery Wastewater by Rhodobacter sphaeroides O.U.001" International Journal of Hydrogen Energy, 25: 1035-1041.

Yigit, D.Ö., Gündüz, U., Türker, L., Yücel, M., Eroglu, I., (1999), “Identification of by- roducts in hydrogen producing bacteria, Rhodobacter sphaeroides O.U.001 grown in the waste water of a sugar refinery". Journal of Biotechnology., 70 (1999), pp. 125-131.

Yu, J., and Takahashi, P. (2007), "Biophotolysis-based hydrogen production by Cyanobacteria and green microalgae". In: Communicating Current Research and 
Educational Topics and Trends in Applied Microbiology, Mendez-Vilas, A. (Ed.). Badajoz, Spain: Formatex Publishing, pp. 79-89.

Xu, L.Y., Ren, N.Q., Wang, A.J., Wang, X.Z., Jie, Y.F., (2007), ”Hydrogen production from molasses fermentation by a novel hydrogen producing strain Ethanoligens sp. B49”, Chinese Journal of Ecology, 26:662-667.

Xu, L.Y., Wang, X.Z., Ren, N.Q., (2007), "Fermentability of molasses and condition of biohydrogen production", Journal of Lisoning Technical University, 26:618-621.

Zhu, H., Wakayama, T., Asada, Y., Miyake, J., (2001), "Hydrogen production by four cultures with participation by anoxygenic phototrophic bacterium and anaerobic bacterium in the presence of . International Journal of Hydrogen Energy, 2001, 26:1149-54.

http://www.iet.uniduesseldorf.de/Frameseiten/Photobiotechnology\&topframenav.ht $\underline{\text { m }}$ (R. capsulatus (a), Institut für Molekulare Enzymetechnologie) http://microbewiki.kenyon.edu/images/a/a7/Rsphaeroides.gif, $R$. Sphaeroides (b) (from Institute of Doe Joint Genome)

http://microbewiki.kenyon.edu/images/6/6e/Palustris.jpg $R$. palustris (c), Dr. GertWieland Kohring, University of Saarland, Germany 


\section{APPENDIX A}

\section{COMPOSITION OF THE MEDIA AND SOLUTIONS}

Table A.1 Composition of the growth medium (20 mM Acetate/10 mM Glutamate, MERCK CHEMICALS)

\begin{tabular}{|c|c|c|}
\hline Components & Amount & Unit \\
\hline $\mathrm{KH}_{2} \mathrm{PO}_{4}(20 \mathrm{mM})$ & 2.73 & $\mathrm{~g} / \mathrm{l}$ \\
\hline $\mathrm{MgSO}_{4} \cdot 7 \mathrm{H}_{2} \mathrm{O}$ & 0.5 & $\mathrm{~g} / \mathrm{l}$ \\
\hline $\mathrm{CaCl}_{2} \cdot 2 \mathrm{H}_{2} \mathrm{O}$ & 0.05 & $\mathrm{~g} / \mathrm{l}$ \\
\hline Vitamin Solution (1X) & 1 & $\mathrm{ml} / \mathrm{l}$ \\
\hline Fe-Citrate Solution (50X) & 0.5 & $\mathrm{ml} / 1$ \\
\hline Trace Element Solution (10X) & 0.1 & $\mathrm{ml} / 1$ \\
\hline Monosodium Glutamate (10 & 1.8 & $\mathrm{~g} / \mathrm{l}$ \\
mM) & & $\mathrm{ml} / \mathrm{l}$ \\
\hline Acetic acid (20 mM) & 1.15 & \\
\hline
\end{tabular}


Table A.2 Composition of sucrose-acetate growth medium (20 mM Sucrose/10 mM Acetate)

\begin{tabular}{|c|c|c|}
\hline Components & Amount & Unit \\
\hline $\mathrm{KH}_{2} \mathrm{PO}_{4}(20 \mathrm{mM})$ & 2.73 & $\mathrm{~g} / \mathrm{l}$ \\
\hline $\mathrm{MgSO}_{4} \cdot 7 \mathrm{H}_{2} \mathrm{O}$ & 0.5 & $\mathrm{~g} / \mathrm{l}$ \\
\hline $\mathrm{CaCl}_{2} \cdot 2 \mathrm{H}_{2} \mathrm{O}$ & 0.05 & $\mathrm{~g} / \mathrm{l}$ \\
\hline Vitamin Solution (1X) & 1.0 & $\mathrm{ml} / 1$ \\
\hline Fe-Citrate Solution (50X) & 0.5 & $\mathrm{ml} / \mathrm{l}$ \\
\hline Trace Element Solution (10X) & 0.1 & $\mathrm{ml} / \mathrm{l}$ \\
\hline Monosodium Glutamate $(2$ & 0.36 & $\mathrm{~g} / 1$ \\
mM) & & $\mathrm{ml} / 1$ \\
\hline Acetic acid (20 mM) & 1.15 & $\mathrm{~g} / 1$ \\
\hline Sucrose (10 Mm) & 3.42 & \\
\hline
\end{tabular}


Table A.3 Composition of sucrose-acetate growth medium (10 mM Sucrose)

\begin{tabular}{|c|c|c|}
\hline Components & Amount & Unit \\
\hline $\mathrm{KH}_{2} \mathrm{PO}_{4}(20 \mathrm{mM})$ & 2.73 & $\mathrm{~g} / \mathrm{l}$ \\
\hline $\mathrm{MgSO}_{4} \cdot 7 \mathrm{H}_{2} \mathrm{O}$ & 0.5 & $\mathrm{~g} / \mathrm{l}$ \\
\hline $\mathrm{CaCl}_{2} .2 \mathrm{H}_{2} \mathrm{O}$ & 0.05 & $\mathrm{~g} / \mathrm{l}$ \\
\hline Vitamin Solution (1X) & 1.0 & $\mathrm{ml} / 1$ \\
\hline Fe-Citrate Solution (50X) & 0.5 & $\mathrm{ml} / 1$ \\
\hline Trace Element Solution (10X) & 0.1 & $\mathrm{ml} / 1$ \\
\hline Monosodium Glutamate (2 \\
mM) & 0.36 & $\mathrm{~g} / \mathrm{l}$ \\
\hline Sucrose (20 Mm) & 3.42 & $\mathrm{~g} / \mathrm{l}$ \\
\hline
\end{tabular}


Table A.4 Hydrogen production media with different sucrose $\left(5^{*}, 7.5^{* *}, 10^{* * *} \mathrm{mM}\right)$ concentrations

\begin{tabular}{|c|c|c|}
\hline Components & Amount & Unit \\
\hline $\mathrm{KH}_{2} \mathrm{PO}_{4}(30 \mathrm{mM})$ & 4.09 & $\mathrm{~g} / \mathrm{l}$ \\
\hline $\mathrm{MgSO}_{4} \cdot 7 \mathrm{H}_{2} \mathrm{O}$ & 0.5 & $\mathrm{~g} / \mathrm{l}$ \\
\hline $\mathrm{CaCl}_{2} .2 \mathrm{H}_{2} \mathrm{O}$ & 0.05 & $\mathrm{~g} / \mathrm{l}$ \\
\hline Vitamin Solution (1X) & 1.0 & $\mathrm{ml} / 1$ \\
\hline Fe-Citrate Solution (50X) & 0.5 & $\mathrm{ml} / 1$ \\
\hline Trace Element Solution (10X) & 0.1 & $\mathrm{ml} / 1$ \\
\hline Monosodium Glutamate $(2$ & 0.36 & $\mathrm{~g} / \mathrm{l}$ \\
\hline mM) & & $\mathrm{g} / \mathrm{l}$ \\
\hline *Sucrose (5 Mm) & 1.71 & $\mathrm{~g} / \mathrm{l}$ \\
\hline$* *$ Sucrose (7.5 Mm) & 2.56 & \\
\hline$* * *$ Sucrose (10 Mm) & 3.42 & \\
\hline
\end{tabular}


A 5. Composition of trace elements solution (1X) components.

\begin{tabular}{|c|c|}
\hline Component & Amount/Unit \\
\hline $\mathrm{HCl}(25 \% \mathrm{v} / \mathrm{v})$ & $1 \mathrm{ml} / \mathrm{l}$ \\
\hline $\mathrm{ZnCl}_{2}$ & $70 \mathrm{mg} / \mathrm{l}$ \\
\hline $\mathrm{MnCl}_{2} \cdot 4 \mathrm{H}_{2} \mathrm{O}$ & $60 \mathrm{mg} / \mathrm{l}$ \\
\hline $\mathrm{H}_{3} \mathrm{BO}_{3}$ & $200 \mathrm{mg} / \mathrm{l}$ \\
\hline $\mathrm{CoCl}_{2} \cdot 6 \mathrm{H}_{2} \mathrm{O}$ & $20 \mathrm{mg} / \mathrm{l}$ \\
\hline $\mathrm{CuCl}_{2} \cdot 2 \mathrm{H}_{2} \mathrm{O}$ & $20 \mathrm{mg} / \mathrm{l}$ \\
\hline $\mathrm{NiCl}_{2} \cdot 6 \mathrm{H}_{2} \mathrm{O}$ & $40 \mathrm{mg} / \mathrm{l}$ \\
\hline $\mathrm{NaMoO}_{4} \cdot 2 \mathrm{H}_{2} \mathrm{O}$ & \\
\hline
\end{tabular}




\section{APPENDIX B}

\section{DRY CELL WEIGHT CURVES}

\section{B1. Dry Cell Weight Determination of PNS bacteria}

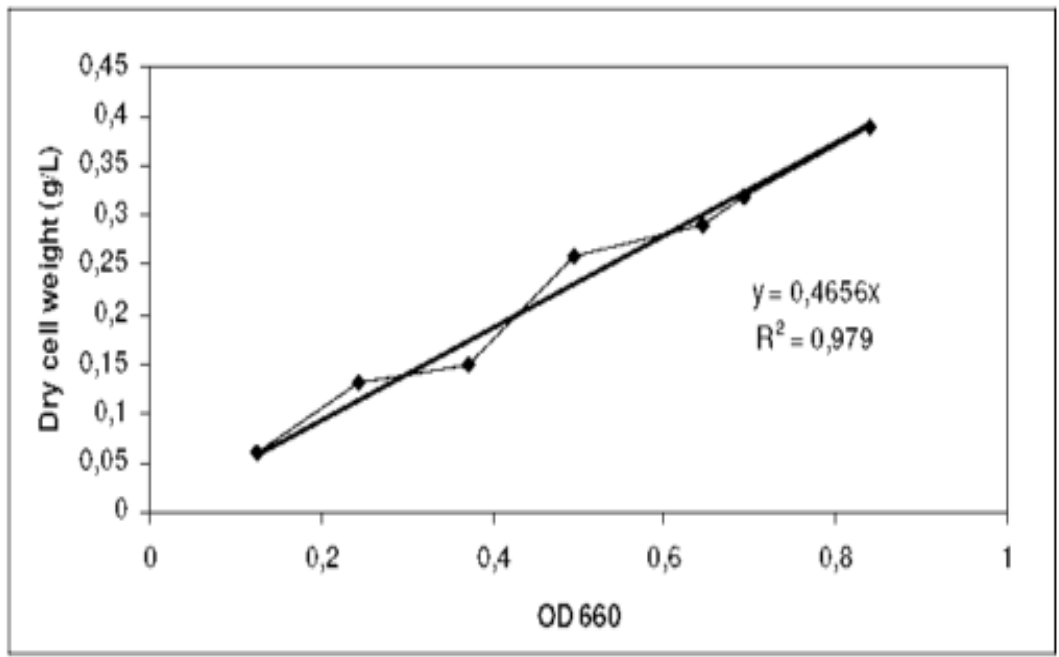

Figure B1. Calibration curve of $R$. capsulatus YO3. (Öztürk, 2005).

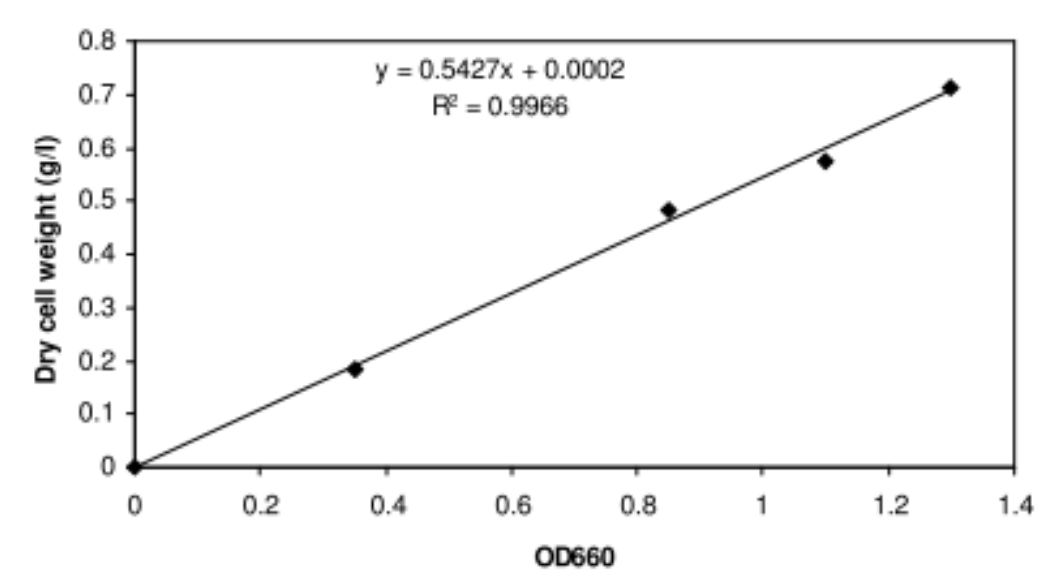


Figure B2. Calibration curve of $R$. capsulatus DSM 1710. (Uyar, 2008).

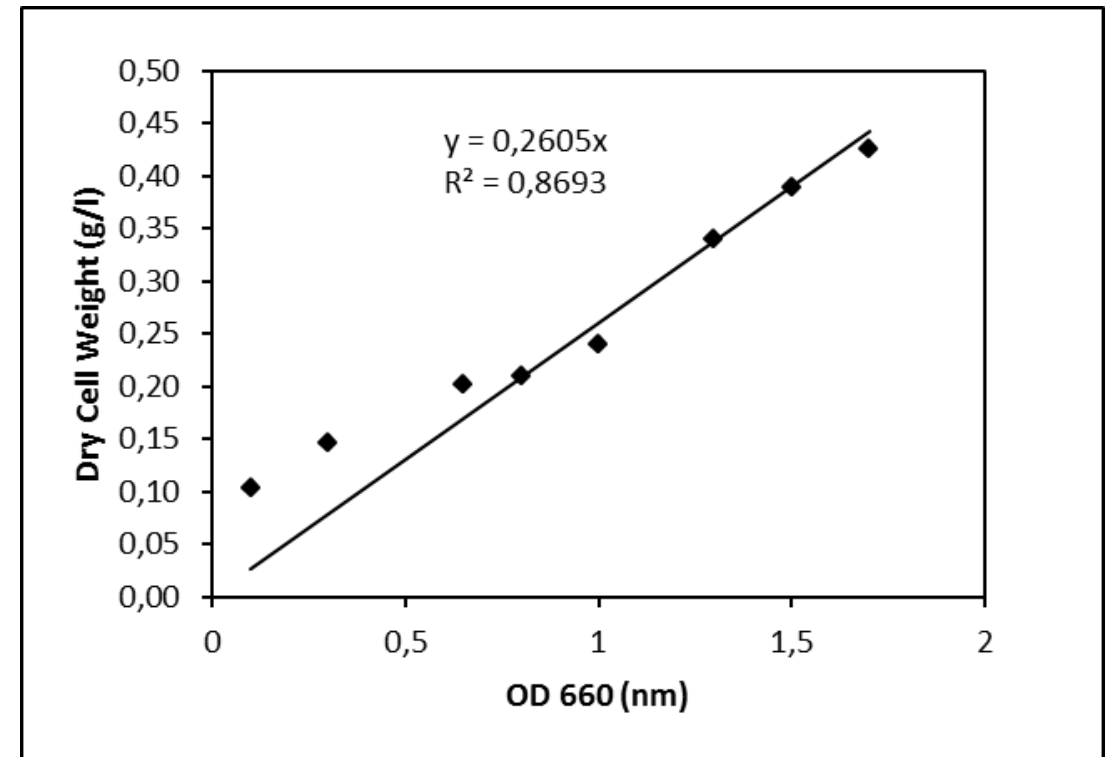

Figure B3. Calibration curve of $R$. palustris (DSM 127). 


\section{APPENDIX C}

\section{SAMPLE SUGAR ANALYSIS}

\section{C1. Sample Sugar HPLC Analysis Chromatogram}

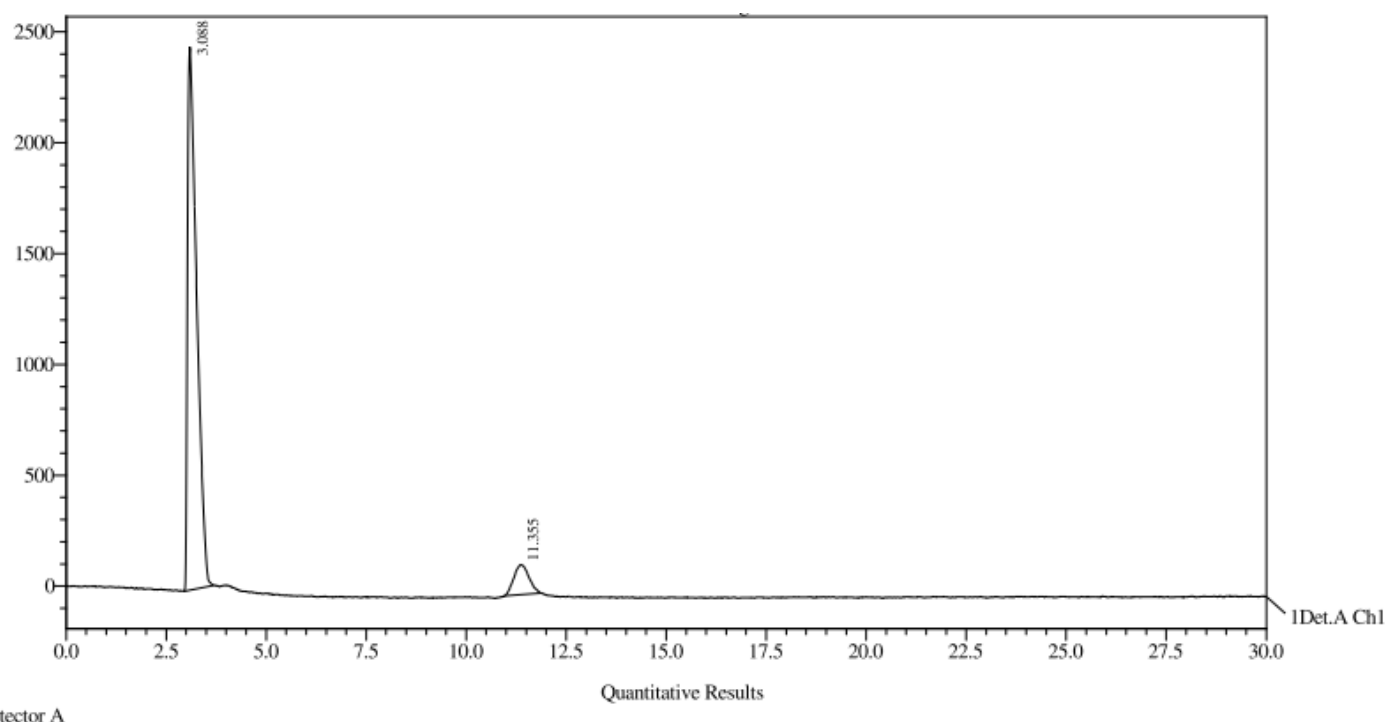

etector A

Figure C1. Sample sugar HPLC chromatogram. Sucrose peak is at 11.3 seconds. Acetonitrile mobile phase peak is at 3.0 seconds. ( $\mathrm{NH} 2$ sugar column and Shimadzu Agilent 10A series HPLC, RID detector) 


\section{C2. Sample HPLC Calibration Curve for Sucrose}

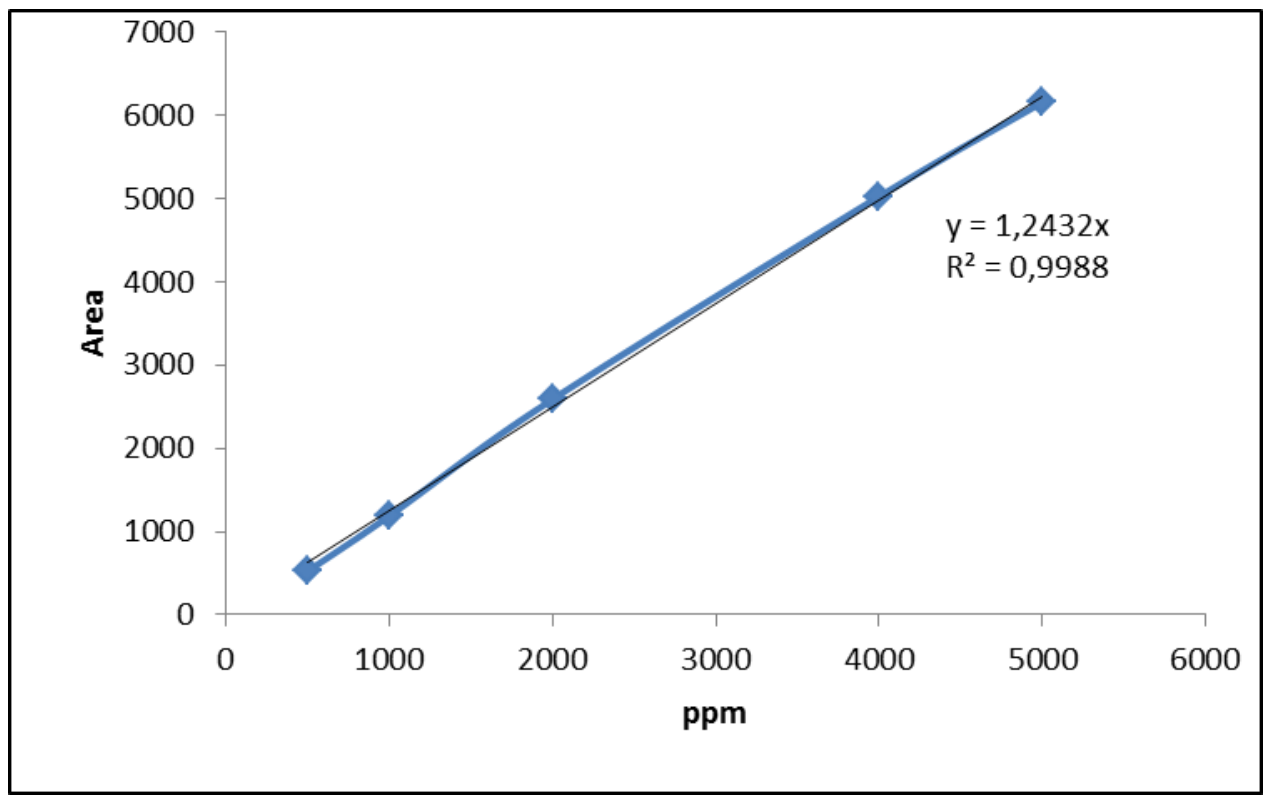

Figure C.2 Sample standard sucrose calibration curve (HPLC, Agilent 10A series). 


\section{APPENDIX D}

\section{ORGANIC ACID ANALYSIS}

\section{1. Sample organic acid chromatogram}

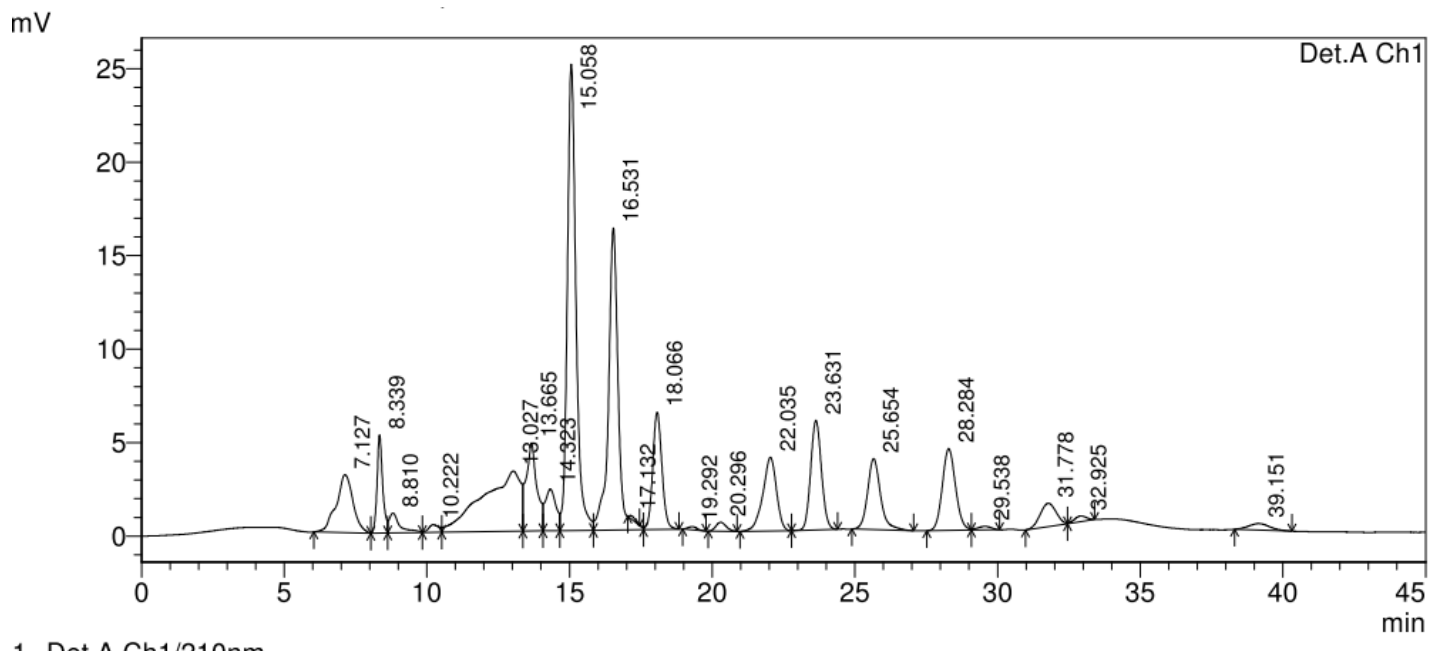

1 Det.A Ch1/210nm

Figure D1. Sample HPLC organic acid chromatogram (Acetic acid peak in 25.654 min and Formic acid peak is in $23.631 \mathrm{~min}$, Shimadzu Agilent 10A series HPLC, UV $210 \mathrm{~nm}$ detector). 
D 2. Sample chromatogram of Acetic Acid Calibration

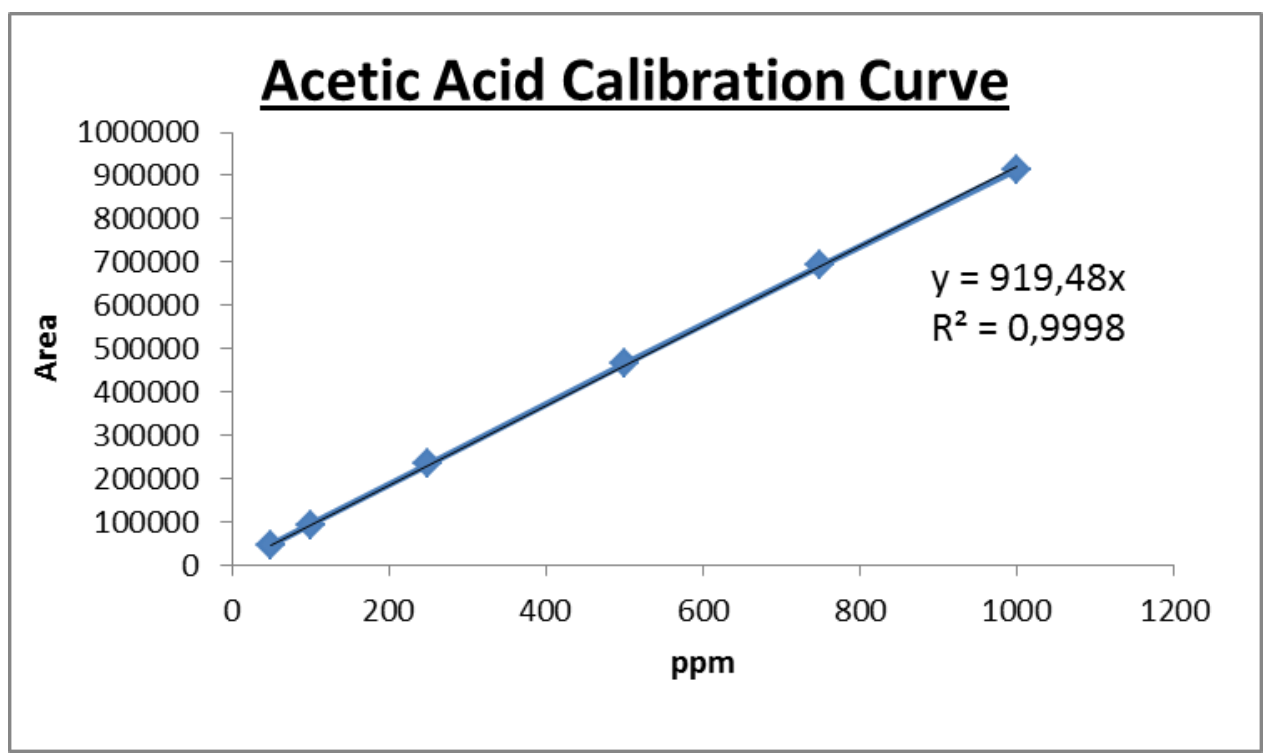

Figure D.1 Calibration curve of sample acetic acid. 


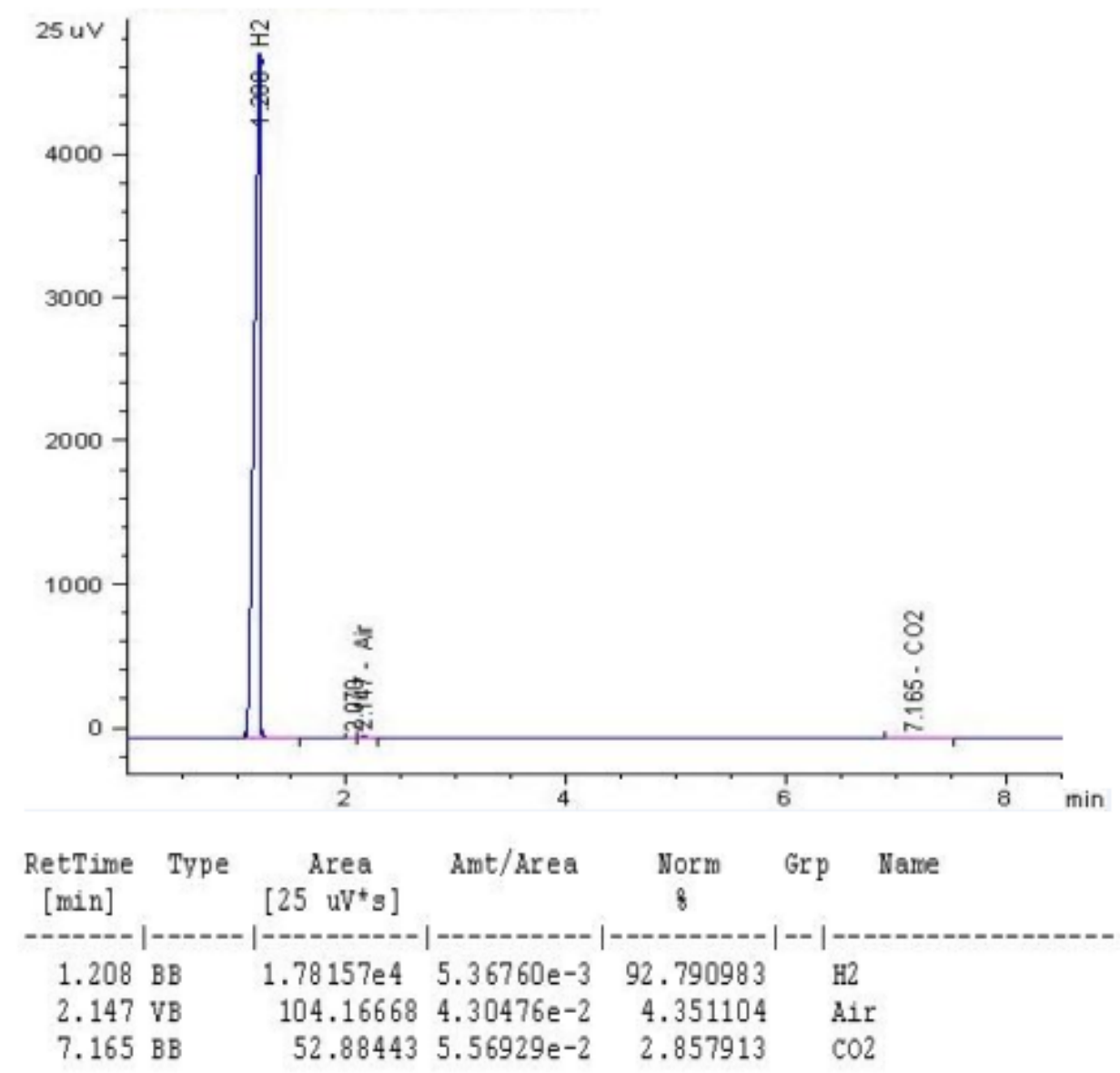

Figure E. Sample gas chromatogram (Agilent Technologies 6890 N gas chromatography) (Androga, 2009). 


\section{APPENDIX F}

\section{COMPOSITION OF MOLASSES}

Table F. Composition of Undiluted Molasses

\begin{tabular}{|c|c|c|}
\hline Parameters & Units & $\begin{array}{c}\text { Results of Chemical } \\
\text { Analysis }\end{array}$ \\
\hline Sucrose & $\mathrm{mM}$ & 1.16 \\
\hline $\begin{array}{l}\text { Alcohol(ethyl } \\
\text { alcohol) }\end{array}$ & $\%(\mathrm{v} / \mathrm{v})$ & 0.16 \\
\hline Phenol & $\mathrm{mg} / \mathrm{L}$ & 25.4 \\
\hline Iron $(\mathrm{Fe})$ & $\mu \mathrm{g} / \mathrm{L}$ & 516.9 \\
\hline Molybdenum (Mo) & $\mu \mathrm{g} / \mathrm{L}$ & 99.7 \\
\hline Sulphur (S) & $\mathrm{mg} / \mathrm{L}$ & 187.1 \\
\hline Potassium (K) & $\mathrm{mg} / \mathrm{L}$ & 5365 \\
\hline Total amino acids & $\mathrm{g} / 100 \mathrm{~g}$ & \\
\hline Aspartic acid & $\mathrm{g} / 100 \mathrm{~g}$ & 0.164 \\
\hline Glutamic acid & $\mathrm{g} / 100 \mathrm{~g}$ & 0.729 \\
\hline Asparagine & $\mathrm{g} / 100 \mathrm{~g}$ & $<0.02^{(1)}$ \\
\hline Serine & $\mathrm{g} / 100 \mathrm{~g}$ & 0.06 \\
\hline Histidine & $\mathrm{g} / 100 \mathrm{~g}$ & $<0.02^{(1)}$ \\
\hline Glycine & $\mathrm{g} / 100 \mathrm{~g}$ & 0.042 \\
\hline Threonine & $\mathrm{g} / 100 \mathrm{~g}$ & $<0.01^{(1)}$ \\
\hline Citrulline & $\mathrm{g} / 100 \mathrm{~g}$ & $<0.02^{(1)}$ \\
\hline
\end{tabular}




\begin{tabular}{|c|c|c|}
\hline Arginine & $\mathrm{g} / 100 \mathrm{~g}$ & $<0.02^{(1)}$ \\
\hline Alanine & $\mathrm{g} / 100 \mathrm{~g}$ & 0.076 \\
\hline Tyrosine & $\mathrm{g} / 100 \mathrm{~g}$ & 0.027 \\
\hline Cystine & $\mathrm{g} / 100 \mathrm{~g}$ & 0.052 \\
\hline Valine & $\mathrm{g} / 100 \mathrm{~g}$ & 0.020 \\
\hline Methionine & $\mathrm{g} / 100 \mathrm{~g}$ & $<0.02^{(1)}$ \\
\hline Tryptophan & $\mathrm{g} / 100 \mathrm{~g}$ & 0.048 \\
\hline Phenylalanine & $\mathrm{g} / 100 \mathrm{~g}$ & $<0.02^{(1)}$ \\
\hline Isoleucine & $\mathrm{g} / 100 \mathrm{~g}$ & 0.030 \\
\hline Ornithine & $\mathrm{g} / 100 \mathrm{~g}$ & 0.025 \\
\hline Leucine & $\mathrm{g} / 100 \mathrm{~g}$ & 0.037 \\
\hline Lysine & $\mathrm{g} / 100 \mathrm{~g}$ & $<0.02^{(1)}$ \\
\hline Hydroxyproline & $\mathrm{g} / 100 \mathrm{~g}$ & $<0.3^{(1)}$ \\
\hline Sarcosine & $\mathrm{g} / 100 \mathrm{~g}$ & $<0.02^{(1)}$ \\
\hline Proline & $\mathrm{g} / 100 \mathrm{~g}$ & $<0.01^{(1)}$ \\
\hline $\begin{array}{l}\text { Total of total amino } \\
\text { acids }\end{array}$ & $\mathrm{g} / 100 \mathrm{~g}$ & 1.3 \\
\hline (1) MDL, & & \\
\hline
\end{tabular}




\section{APPENDIX G}

\section{EXPERIMENTAL DATA}

Table G1 OD, pH, dry cell weight and hydrogen production of $5 \mathrm{mM}$ sucrose containing molasses medium by $R$. capsulatus DSM 1710

\begin{tabular}{|c|c|c|c|c|c|}
\hline Time (h) & $\begin{array}{c}\text { OD }(660 \\
\mathrm{nm})\end{array}$ & $\begin{array}{c}\text { Dry Cell } \\
\text { Weight } \\
\left(\mathrm{gdcw} / \mathrm{l}_{\mathrm{c}}\right)\end{array}$ & $\mathrm{pH}$ & $\begin{array}{c}\text { Cumulative } \\
\text { Hydrogen }(\mathrm{ml})\end{array}$ & $\begin{array}{c}\text { Cumulative } \\
\text { Hydrogen } \\
\left(1 / \mathrm{l}_{\mathrm{c}}\right)\end{array}$ \\
\hline 0 & 0,34 & 0,17 & 7,292 & 0 & 0,00 \\
\hline 24 & 0,98 & 0,49 & 7,012 & 2 & 0,04 \\
\hline 48 & 1,04 & 0,52 & 6,923 & 4 & 0,08 \\
\hline 72 & 1,15 & 0,58 & 6,707 & 7 & 0,14 \\
\hline 96 & 1,1 & 0,55 & 6,73 & 8 & 0,16 \\
\hline 120 & 0,83 & 0,42 & 6,757 & 9 & 0,18 \\
\hline 144 & 0,83 & 0,42 & 6,658 & 10 & 0,20 \\
\hline 180 & 0,75 & 0,38 & 6,463 & 10 & 0,20 \\
\hline
\end{tabular}

Table G2 Organic acid concentrations (mM) in $5 \mathrm{mM}$ sucrose medium by $R$. capsulatus DSM 1710.

\begin{tabular}{|c|c|c|c|c|c|}
\hline Time (h) & $\begin{array}{c}\text { Acetic acid } \\
(\mathrm{mM})\end{array}$ & $\begin{array}{c}\text { Lactic acid } \\
(\mathrm{mM})\end{array}$ & $\begin{array}{c}\text { Formic } \\
\text { acid }(\mathrm{mM})\end{array}$ & $\begin{array}{c}\text { Propionic acid } \\
(\mathrm{mM})\end{array}$ & $\begin{array}{c}\text { Butyric acid } \\
(\mathrm{mM})\end{array}$ \\
\hline 0 & 0,12 & 0,43 & 0,64 & - & - \\
\hline 72 & 0,31 & 0,84 & 1,98 & - & - \\
\hline 144 & 3,32 & 0,08 & 16,40 & - & - \\
\hline
\end{tabular}


Table G3 OD, pH, dry cell weight and hydrogen production of $7.5 \mathrm{mM}$ sucrose defined medium by $R$. capsulatus DSM 1710

\begin{tabular}{|c|c|c|c|c|c|}
\hline Time (h) & $\begin{array}{c}\text { OD }(660 \\
\mathrm{nm})\end{array}$ & $\begin{array}{c}\text { Dry Cell } \\
\text { Weight } \\
\left(\mathrm{gdcw} / \mathrm{l}_{\mathrm{c}}\right)\end{array}$ & $\mathrm{pH}$ & $\begin{array}{c}\text { Cumulative } \\
\text { Hydrogen } \\
(\mathrm{ml})\end{array}$ & $\begin{array}{c}\text { Cumulative } \\
\text { Hydrogen } \\
\left(1 / l_{\mathrm{c}}\right)\end{array}$ \\
\hline 0 & 0,5 & 0,25 & 7,255 & 0 & 0,00 \\
\hline 24 & 0,7 & 0,35 & 7,1 & 25 & 0,50 \\
\hline 48 & 1,05 & 0,53 & 6,855 & 33 & 0,66 \\
\hline 72 & 1,19 & 0,60 & 6,625 & 35 & 0,70 \\
\hline 96 & 1,08 & 0,54 & 6,51 & 37 & 0,74 \\
\hline 120 & 0,9 & 0,45 & 6,394 & 40 & 0,80 \\
\hline 144 & 0,88 & 0,44 & 6,381 & 43 & 0,86 \\
\hline 180 & 0,88 & 0,44 & 6,362 & 43 & 0,86 \\
\hline
\end{tabular}

Table G4 Organic acid concentrations $(\mathrm{mM})$ in $7.5 \mathrm{mM}$ sucrose medium by $R$. capsulatus DSM 1710.

\begin{tabular}{|c|r|c|c|c|c|}
\hline Time (h) & $\begin{array}{c}\text { Acetic } \\
\text { acid (mM) }\end{array}$ & $\begin{array}{c}\text { Lactic acid } \\
(\mathrm{mM})\end{array}$ & $\begin{array}{c}\text { Formic } \\
\text { acid } \\
(\mathrm{mM})\end{array}$ & $\begin{array}{c}\text { Propionic } \\
\text { acid (mM) }\end{array}$ & $\begin{array}{c}\text { Butyric } \\
\text { acid (mM) }\end{array}$ \\
\hline 0 & 0,04 & 0,23 & 0,39 & - & - \\
\hline 72 & 0,62 & 1,47 & 3,51 & - & - \\
\hline 144 & 1,18 & 0,99 & 2,57 & - & - \\
\hline
\end{tabular}


Table G5 OD, pH, dry cell weight and hydrogen production of $10 \mathrm{mM}$ sucrose defined medium by $R$. capsulatus DSM 1710

\begin{tabular}{|c|c|c|c|c|c|}
\hline Time (h) & $\begin{array}{c}\text { OD }(660 \\
\mathrm{nm})\end{array}$ & $\begin{array}{c}\text { Dry Cell } \\
\text { Weight } \\
\left(\mathrm{gdcw} / \mathrm{l}_{\mathrm{c}}\right)\end{array}$ & $\mathrm{pH}$ & $\begin{array}{c}\text { Cumulative } \\
\text { Hydrogen } \\
(\mathrm{ml})\end{array}$ & $\begin{array}{c}\text { Cumulative } \\
\text { Hydrogen } \\
\left(1 / \mathrm{l}_{\mathrm{c}}\right)\end{array}$ \\
\hline 0 & 0,42 & 0,21 & 7,295 & 0 & 0,00 \\
\hline 24 & 0,88 & 0,44 & 7,127 & 10 & 0,20 \\
\hline 48 & 1,08 & 0,54 & 6,866 & 17 & 0,34 \\
\hline 72 & 1,26 & 0,63 & 6,667 & 22 & 0,44 \\
\hline 96 & 1,03 & 0,52 & 6,519 & 23 & 0,46 \\
\hline 120 & 0,88 & 0,44 & 6,424 & 25 & 0,50 \\
\hline 144 & 0,75 & 0,38 & 6,107 & 27 & 0,54 \\
\hline 180 & 0,83 & 0,42 & 6,05 & 30 & 0,60 \\
\hline
\end{tabular}

Table G6 Organic acid concentrations (mM) in $10 \mathrm{mM}$ sucrose medium by $R$. capsulatus DSM 1710.

\begin{tabular}{|c|c|c|c|c|c|}
\hline Time (h) & $\begin{array}{c}\text { Acetic } \\
\text { acid (mM) }\end{array}$ & $\begin{array}{c}\text { Lactic acid } \\
(\mathrm{mM})\end{array}$ & $\begin{array}{c}\text { Formic } \\
\text { acid } \\
(\mathrm{mM})\end{array}$ & $\begin{array}{c}\text { Propionic } \\
\text { acid (mM) }\end{array}$ & $\begin{array}{c}\text { Butyric } \\
\text { acid (mM) }\end{array}$ \\
\hline 0 & 0,02 & 0,04 & 0,26 & - & - \\
\hline 72 & 0,48 & 1,28 & 2,70 & - & - \\
\hline 144 & 4,17 & 0,00 & 6,11 & - & - \\
\hline
\end{tabular}


Table G7 OD, pH, dry cell weight and hydrogen production of $5 \mathrm{mM}$ sucrose defined medium by R. capsulatus YO3

\begin{tabular}{|c|c|c|c|c|c|}
\hline Time (h) & $\begin{array}{c}\text { OD }(660 \\
\mathrm{nm})\end{array}$ & $\begin{array}{c}\text { Dry Cell } \\
\text { Weight } \\
\left(\mathrm{gdcw} / \mathrm{l}_{\mathrm{c}}\right)\end{array}$ & $\mathrm{pH}$ & $\begin{array}{c}\text { Cumulative } \\
\text { Hydrogen } \\
(\mathrm{ml})\end{array}$ & $\begin{array}{c}\text { Cumulative } \\
\text { Hydrogen } \\
\left(1 / 1_{\mathrm{c}}\right)\end{array}$ \\
\hline 0 & 0,23 & 0,13 & 7,59 & 0 & 0 \\
\hline 24 & 0,58 & 0,32 & 7,11 & 16 & 0,32 \\
\hline 48 & 0,74 & 0,41 & 6,72 & 16 & 0,32 \\
\hline 72 & 0,76 & 0,42 & 6,26 & 16 & 0,32 \\
\hline 96 & 0,88 & 0,48 & 6,14 & 40 & 0,8 \\
\hline 120 & 0,96 & 0,53 & 6,09 & 40 & 0,8 \\
\hline 168 & 0,89 & 0,49 & 5,75 & 40 & 0,8 \\
\hline 212 & 0,85 & 0,47 & 5,75 & 40 & 0,8 \\
\hline
\end{tabular}

Table G8 Organic acid concentrations $(\mathrm{mM})$ in $5 \mathrm{mM}$ sucrose medium by $\mathrm{R}$. capsulatus YO3

\begin{tabular}{|c|c|c|c|c|c|}
\hline Time (h) & $\begin{array}{c}\text { Acetic } \\
\text { acid (mM) }\end{array}$ & $\begin{array}{c}\text { Lactic acid } \\
(\mathrm{mM})\end{array}$ & $\begin{array}{c}\text { Formic } \\
\text { acid } \\
(\mathrm{mM})\end{array}$ & $\begin{array}{c}\text { Propionic } \\
\text { acid (mM) }\end{array}$ & $\begin{array}{c}\text { Butyric } \\
\text { acid (mM) }\end{array}$ \\
\hline 0 & 3,14 & - & 2,11 & - & - \\
\hline 72 & 2,22 & - & 2,73 & - & - \\
\hline 144 & 3,09 & - & 3,48 & - & - \\
\hline
\end{tabular}


Table G9 OD, pH, dry cell weight and hydrogen production of $7.5 \mathrm{mM}$ sucrose defined medium by R. capsulatus YO3

\begin{tabular}{|c|c|c|c|c|c|}
\hline Time $(\mathrm{h})$ & $\begin{array}{c}\text { OD }(660 \\
\mathrm{nm})\end{array}$ & $\begin{array}{c}\text { Dry Cell } \\
\text { Weight } \\
\left(\mathrm{gdcw} / \mathrm{l}_{\mathrm{c}}\right)\end{array}$ & $\mathrm{pH}$ & $\begin{array}{c}\text { Cumulative } \\
\text { Hydrogen } \\
(\mathrm{ml})\end{array}$ & $\begin{array}{c}\text { Cumulative } \\
\text { Hydrogen } \\
\left(1 / 1_{\mathrm{c}}\right)\end{array}$ \\
\hline 0 & 0,27 & 0,15 & 7,35 & 0 & 0,00 \\
\hline 24 & 0,62 & 0,34 & 7,12 & 4,06 & 0,08 \\
\hline 48 & 0,75 & 0,41 & 7 & 8,7 & 0,17 \\
\hline 72 & 0,78 & 0,43 & 6,3 & 12,76 & 0,26 \\
\hline 96 & 0,89 & 0,49 & 6,2 & 14,96 & 0,30 \\
\hline 120 & 0,95 & 0,52 & 6,02 & 17,6 & 0,35 \\
\hline 168 & 0,95 & 0,52 & 5,8 & 23,32 & 0,47 \\
\hline 212 & 0,98 & 0,54 & 5,87 & 25,08 & 0,50 \\
\hline
\end{tabular}

Table G10 Organic acid concentrations $(\mathrm{mM})$ in $7.5 \mathrm{mM}$ sucrose medium by $R$. capsulatus YO3

\begin{tabular}{|c|c|c|c|c|c|}
\hline Time (h) & $\begin{array}{c}\text { Acetic } \\
\text { acid (mM) }\end{array}$ & $\begin{array}{c}\text { Lactic acid } \\
(\mathrm{mM})\end{array}$ & $\begin{array}{c}\text { Formic } \\
\text { acid } \\
(\mathrm{mM})\end{array}$ & $\begin{array}{c}\text { Propionic } \\
\text { acid (mM) }\end{array}$ & $\begin{array}{c}\text { Butyric } \\
\text { acid (mM) }\end{array}$ \\
\hline 0 & 0,32 & 0,2 & 3,12 & - & - \\
\hline 72 & 1,2 & 0,1 & 3,85 & - & - \\
\hline 144 & 4,54 & 0 & 4,32 & - & - \\
\hline
\end{tabular}


Table G11 OD, pH, dry cell weight and hydrogen production of $10 \mathrm{mM}$ sucrose defined medium by $R$. capsulatus YO3

\begin{tabular}{|c|c|c|c|c|c|}
\hline Time (h) & $\begin{array}{c}\text { OD }(660 \\
\mathrm{nm})\end{array}$ & $\begin{array}{c}\text { Dry Cell } \\
\text { Weight } \\
\left(\mathrm{gdcw} / \mathrm{l}_{\mathrm{c}}\right)\end{array}$ & $\mathrm{pH}$ & $\begin{array}{c}\text { Cumulative } \\
\text { Hydrogen } \\
(\mathrm{ml})\end{array}$ & $\begin{array}{c}\text { Cumulative } \\
\text { Hydrogen } \\
\left(1 / 1_{\mathrm{c}}\right)\end{array}$ \\
\hline 0 & 0,31 & 0,17 & 7,3 & 0 & 0,00 \\
\hline 24 & 0,69 & 0,38 & 7,23 & 2,08 & 0,04 \\
\hline 48 & 0,78 & 0,43 & 7,05 & 5,76 & 0,12 \\
\hline 72 & 0,82 & 0,45 & 6,4 & 9,12 & 0,18 \\
\hline 96 & 1,00 & 0,55 & 6,34 & 10,32 & 0,21 \\
\hline 120 & 1,09 & 0,6 & 6 & 12,32 & 0,25 \\
\hline 168 & 1,13 & 0,62 & 5,99 & 18,72 & 0,37 \\
\hline 212 & 1,16 & 0,64 & 5,8 & 20,72 & 0,41 \\
\hline
\end{tabular}

Table G12 Organic acid concentrations (mM) in $10 \mathrm{mM}$ sucrose medium by $R$. capsulatus YO3

\begin{tabular}{|c|c|c|c|c|c|}
\hline Time (h) & $\begin{array}{c}\text { Acetic } \\
\text { acid (mM) }\end{array}$ & $\begin{array}{c}\text { Lactic acid } \\
(\mathrm{mM})\end{array}$ & $\begin{array}{c}\text { Formic } \\
\text { acid } \\
(\mathrm{mM})\end{array}$ & $\begin{array}{c}\text { Propionic } \\
\text { acid (mM) }\end{array}$ & $\begin{array}{c}\text { Butyric } \\
\text { acid (mM) }\end{array}$ \\
\hline 0 & 0,23 & 0,12 & 3,45 & - & - \\
\hline 72 & 3,37 & 0,4 & 4,2 & - & - \\
\hline 144 & 5,65 & 0,08 & 5,32 & - & - \\
\hline
\end{tabular}


Table G13 OD, pH, dry cell weight and hydrogen production of $5 \mathrm{mM}$ sucrose defined medium by $R$. palustris (DSM 127)

\begin{tabular}{|c|c|c|c|c|c|}
\hline Time (h) & $\begin{array}{c}\text { OD }(660 \\
\mathrm{nm})\end{array}$ & $\begin{array}{c}\text { Dry Cell } \\
\text { Weight } \\
\left(\mathrm{gdcw} / \mathrm{l}_{\mathrm{c}}\right)\end{array}$ & $\mathrm{pH}$ & $\begin{array}{c}\text { Cumulative } \\
\text { Hydrogen } \\
(\mathrm{ml})\end{array}$ & $\begin{array}{c}\text { Cumulative } \\
\text { Hydrogen } \\
\left(1 / 1_{\mathrm{c}}\right)\end{array}$ \\
\hline 0 & 0,21 & 0,05 & 7,07 & 0 & 0 \\
\hline 24 & 1,14 & 0,30 & 7,25 & 18,9 & 0,378 \\
\hline 48 & 1,05 & 0,27 & 6,72 & 42,3 & 0,846 \\
\hline 72 & 0,92 & 0,24 & 6,68 & 63,3 & 1,266 \\
\hline 120 & 0,79 & 0,21 & 6,72 & 66,9 & 1,338 \\
\hline 144 & 0,75 & 0,20 & 6,85 & 67,5 & 1,35 \\
\hline 168 & 0,73 & 0,19 & 6,69 & 67,8 & 1,356 \\
\hline 192 & 0,58 & 0,15 & 6,92 & 68,1 & 1,362 \\
\hline
\end{tabular}

Table G14 Organic acid concentrations (mM) in $5 \mathrm{mM}$ sucrose medium by $R$. palustris (DSM 127)

\begin{tabular}{|c|c|c|c|c|c|}
\hline Time (h) & $\begin{array}{c}\text { Acetic } \\
\text { acid (mM) }\end{array}$ & $\begin{array}{c}\text { Lactic acid } \\
(\mathrm{mM})\end{array}$ & $\begin{array}{c}\text { Formic } \\
\text { acid } \\
(\mathrm{mM})\end{array}$ & $\begin{array}{c}\text { Propionic } \\
\text { acid (mM) }\end{array}$ & $\begin{array}{c}\text { Butyric } \\
\text { acid (mM) }\end{array}$ \\
\hline 0 & 0,07 & 0,15 & 0,42 & - & - \\
\hline 72 & 2,17 & 1,86 & 2,32 & - & - \\
\hline 144 & 0,00 & 0,00 & 3,06 & - & - \\
\hline
\end{tabular}


Table G15 OD, pH, dry cell weight and hydrogen production of $7.5 \mathrm{mM}$ sucrose defined medium by $R$. palustris (DSM 1710)

\begin{tabular}{|c|c|c|c|c|c|}
\hline Time (h) & $\begin{array}{c}\text { OD }(660 \\
\mathrm{nm})\end{array}$ & $\begin{array}{c}\text { Dry Cell } \\
\text { Weight } \\
\left(\mathrm{gdcw} / \mathrm{l}_{\mathrm{c}}\right)\end{array}$ & $\mathrm{pH}$ & $\begin{array}{c}\text { Cumulative } \\
\text { Hydrogen } \\
(\mathrm{ml})\end{array}$ & $\begin{array}{c}\text { Cumulative } \\
\text { Hydrogen } \\
\left(1 / 1_{\mathrm{c}}\right)\end{array}$ \\
\hline 0 & 0,21 & 0,05 & 7,22 & 0 & 0 \\
\hline 24 & 1,25 & 0,32 & 7,18 & 16,2 & 0,324 \\
\hline 48 & 1,03 & 0,27 & 6,69 & 36 & 0,72 \\
\hline 72 & 1,46 & 0,38 & 6,54 & 55,8 & 1,116 \\
\hline 120 & 1,21 & 0,31 & 6,61 & 63,6 & 1,272 \\
\hline 144 & 1,20 & 0,31 & 6,75 & 69,6 & 1,392 \\
\hline 168 & 0,82 & 0,21 & 6,66 & 71,4 & 1,428 \\
\hline 192 & 0,67 & 0,17 & 6,74 & 75 & 1,5 \\
\hline
\end{tabular}

Table G16 Organic acid concentrations (mM) in $7.5 \mathrm{mM}$ sucrose medium by $R$. palustris (DSM 127)

\begin{tabular}{|c|r|c|c|c|c|}
\hline Time (h) & $\begin{array}{r}\text { Acetic } \\
\text { acid (mM) }\end{array}$ & $\begin{array}{c}\text { Lactic acid } \\
(\mathrm{mM})\end{array}$ & $\begin{array}{c}\text { Formic } \\
\text { acid } \\
(\mathrm{mM})\end{array}$ & $\begin{array}{c}\text { Propionic } \\
\text { acid (mM) }\end{array}$ & $\begin{array}{c}\text { Butyric } \\
\text { acid (mM) }\end{array}$ \\
\hline 0 & 0,09 & 0,14 & 0,43 & 0,00 & - \\
\hline 72 & 2,31 & 0,00 & 2,88 & 0,00 & - \\
\hline 144 & 12,06 & 0,00 & 10,47 & 0,21 & - \\
\hline
\end{tabular}


Table G17 OD, pH, dry cell weight and hydrogen production of $10 \mathrm{mM}$ sucrose defined medium by $R$. palustris (DSM 127)

\begin{tabular}{|c|c|c|c|c|c|}
\hline Time (h) & $\begin{array}{c}\text { OD }(660 \\
\mathrm{nm})\end{array}$ & $\begin{array}{c}\text { Dry Cell } \\
\text { Weight } \\
\left(\mathrm{gdcw} / \mathrm{l}_{\mathrm{c}}\right)\end{array}$ & $\mathrm{pH}$ & $\begin{array}{c}\text { Cumulative } \\
\text { Hydrogen } \\
(\mathrm{ml})\end{array}$ & $\begin{array}{c}\text { Cumulative } \\
\text { Hydrogen } \\
\left(1 / 1_{\mathrm{c}}\right)\end{array}$ \\
\hline 0 & 0,20 & 0,05 & 7,25 & 0 & 0 \\
\hline 24 & 1,16 & 0,30 & 7,19 & 13,5 & 0,27 \\
\hline 48 & 1,20 & 0,31 & 6,74 & 25,2 & 0,504 \\
\hline 72 & 1,34 & 0,35 & 6,58 & 37,2 & 0,744 \\
\hline 120 & 1,18 & 0,31 & 6,54 & 45 & 0,90 \\
\hline 144 & 0,97 & 0,25 & 6,60 & 50,4 & 1,008 \\
\hline 168 & 0,98 & 0,25 & 6,56 & 52,2 & 1,044 \\
\hline 192 & 0,69 & 0,18 & 6,60 & 55,2 & 1,104 \\
\hline
\end{tabular}

Table G18 Organic acid concentrations (mM) in $10 \mathrm{mM}$ sucrose medium by $R$. palustris (DSM 127)

\begin{tabular}{|c|c|c|c|c|c|}
\hline Time (h) & $\begin{array}{c}\text { Acetic } \\
\text { acid (mM) }\end{array}$ & $\begin{array}{c}\text { Lactic acid } \\
(\mathrm{mM})\end{array}$ & $\begin{array}{c}\text { Formic } \\
\text { acid } \\
(\mathrm{mM})\end{array}$ & $\begin{array}{c}\text { Propionic } \\
\text { acid (mM) }\end{array}$ & $\begin{array}{c}\text { Butyric } \\
\text { acid (mM) }\end{array}$ \\
\hline 0 & 0,21 & 0,19 & 0,58 & 0,00 & - \\
\hline 72 & 2,69 & 0,00 & 2,69 & 0,77 & - \\
\hline 144 & 19,15 & 0,00 & 5,76 & 0,14 & - \\
\hline
\end{tabular}


Table G19 OD, pH, dry cell weight and hydrogen production of $5 \mathrm{mM}$ sucrose containing molasses medium by $R$. sphaeroides O.U.001

\begin{tabular}{|c|c|c|c|c|c|}
\hline Time (h) & $\begin{array}{c}\text { OD } \\
(660 \mathrm{~nm})\end{array}$ & $\begin{array}{c}\text { Dry Cell } \\
\text { Weight } \\
\left(\mathrm{gdcw} / \mathrm{l}_{\mathrm{c}}\right)\end{array}$ & $\mathrm{pH}$ & $\begin{array}{c}\text { Cumulative } \\
\text { Hydrogen } \\
(\mathrm{ml})\end{array}$ & $\begin{array}{c}\text { Cumulative } \\
\text { Hydrogen } \\
\left(1 / 1_{\mathrm{c}}\right)\end{array}$ \\
\hline 0 & 0,28 & 0,15 & 7,57 & 0,00 & 0,00 \\
\hline 24 & - & - & - & - & - \\
\hline 48 & 1,13 & 0,62 & 7,56 & 22,00 & 0,44 \\
\hline 72 & 1,17 & 0,64 & 7,16 & 30,00 & 0,60 \\
\hline 96 & 1,02 & 0,56 & 7,09 & 38,50 & 0,77 \\
\hline 120 & 0,85 & 0,47 & 7,07 & 40,20 & 0,80 \\
\hline 144 & 0,88 & 0,48 & 6,87 & 42,00 & 0,84 \\
\hline 180 & 0,94 & 0,52 & 6,94 & 43,00 & 0,86 \\
\hline
\end{tabular}

Table G20 Organic acid concentrations (mM) in $5 \mathrm{mM}$ sucrose medium by $R$.

sphaeroides O.U.001

\begin{tabular}{|c|c|c|c|c|c|}
\hline Time (h) & $\begin{array}{c}\text { Acetic } \\
\text { acid (mM) }\end{array}$ & $\begin{array}{c}\text { Lactic acid } \\
(\mathrm{mM})\end{array}$ & $\begin{array}{c}\text { Formic } \\
\text { acid } \\
(\mathrm{mM})\end{array}$ & $\begin{array}{c}\text { Propionic } \\
\text { acid (mM) }\end{array}$ & $\begin{array}{c}\text { Butyric } \\
\text { acid (mM) }\end{array}$ \\
\hline 0 & 0,04 & 0,10 & 0,04 & - & - \\
\hline 72 & -- & - & - & - & - \\
\hline 144 & 0,10 & 0,68 & 0,10 & - & - \\
\hline
\end{tabular}


Table G21 OD, pH, dry cell weight and hydrogen production of $7.5 \mathrm{mM}$ sucrose containing molasses medium by $R$. sphaeroides O.U.001

\begin{tabular}{|c|c|c|c|c|c|}
\hline Time $(\mathrm{h})$ & $\begin{array}{c}\text { OD } \\
(660 \mathrm{~nm})\end{array}$ & $\begin{array}{c}\text { Dry Cell } \\
\text { Weight } \\
\left(\mathrm{gdcw} / \mathrm{l}_{\mathrm{c}}\right)\end{array}$ & $\mathrm{pH}$ & $\begin{array}{c}\text { Cumulative } \\
\text { Hydrogen } \\
(\mathrm{ml})\end{array}$ & $\begin{array}{c}\text { Cumulative } \\
\text { Hydrogen } \\
\left(1 / 1_{\mathrm{c}}\right)\end{array}$ \\
\hline 0 & 0,28 & 0,15 & 7,59 & 0,00 & 0,00 \\
\hline 24 & - & - & - & - & - \\
\hline 48 & 1,24 & 0,68 & 7,46 & 18,00 & 0,36 \\
\hline 72 & 1,23 & 0,68 & 7,14 & 26,00 & 0,52 \\
\hline 96 & 1,01 & 0,56 & 7,14 & 27,00 & 0,54 \\
\hline 120 & 1,07 & 0,59 & 7,00 & 30,00 & 0,60 \\
\hline 144 & 0,82 & 0,45 & 6,89 & 30,00 & 0,60 \\
\hline 180 & 1,03 & 0,57 & 6,76 & 30,00 & 0,60 \\
\hline
\end{tabular}

Table G22 Organic acid concentrations (mM) in $7.5 \mathrm{mM}$ sucrose medium by $R$. sphaeroides O.U.001

\begin{tabular}{|c|c|c|c|c|c|}
\hline Time (h) & $\begin{array}{c}\text { Acetic } \\
\text { acid (mM) }\end{array}$ & $\begin{array}{c}\text { Lactic acid } \\
(\mathrm{mM})\end{array}$ & $\begin{array}{c}\text { Formic } \\
\text { acid } \\
(\mathrm{mM})\end{array}$ & $\begin{array}{c}\text { Propionic } \\
\text { acid (mM) }\end{array}$ & $\begin{array}{c}\text { Butyric } \\
\text { acid (mM) }\end{array}$ \\
\hline 0 & 0,00 & 0,00 & 0,00 & - & - \\
\hline 72 & - & - & - & - & - \\
\hline 144 & 0,06 & 1,07 & 0,06 & - & - \\
\hline
\end{tabular}


Table G23 OD, pH, dry cell weight and hydrogen production of $10 \mathrm{mM}$ sucrose containing molasses medium by $R$. sphaeroides O.U.001

\begin{tabular}{|c|c|c|c|c|c|}
\hline Time (h) & $\begin{array}{c}\text { OD } \\
(660 \mathrm{~nm})\end{array}$ & $\begin{array}{c}\text { Dry Cell } \\
\text { Weight } \\
\left(\mathrm{gdcw} / \mathrm{l}_{\mathrm{c}}\right)\end{array}$ & $\mathrm{pH}$ & $\begin{array}{c}\text { Cumulative } \\
\text { Hydrogen } \\
(\mathrm{ml})\end{array}$ & $\begin{array}{c}\text { Cumulative } \\
\text { Hydrogen } \\
\left(1 / 1_{\mathrm{c}}\right)\end{array}$ \\
\hline 0 & 0,32 & 0,18 & 7,53 & 0,00 & 0,00 \\
\hline 24 & - & - & - & - & - \\
\hline 48 & 1,22 & 0,67 & 7,49 & 13,00 & 0,26 \\
\hline 72 & 1,22 & 0,67 & 7,17 & 24,00 & 0,48 \\
\hline 96 & 1,00 & 0,55 & 7,09 & 32,00 & 0,64 \\
\hline 120 & 1,12 & 0,62 & 7,10 & 35,00 & 0,70 \\
\hline 144 & 0,92 & 0,51 & 6,87 & 36,00 & 0,72 \\
\hline 180 & 0,92 & 0,51 & 6,84 & 37,00 & 0,74 \\
\hline
\end{tabular}

Table G24 Organic acid concentrations in $10 \mathrm{mM}$ sucrose medium by $R$. sphaeroides O.U.001

\begin{tabular}{|c|c|c|c|c|c|}
\hline Time (h) & $\begin{array}{c}\text { Acetic } \\
\text { acid (mM) }\end{array}$ & $\begin{array}{c}\text { Lactic acid } \\
(\mathrm{mM})\end{array}$ & $\begin{array}{c}\text { Formic } \\
\text { acid } \\
(\mathrm{mM})\end{array}$ & $\begin{array}{c}\text { Propionic } \\
\text { acid (mM) }\end{array}$ & $\begin{array}{c}\text { Butyric } \\
\text { acid (mM) }\end{array}$ \\
\hline 0 & 0,05 & 0,02 & 0,05 & - & - \\
\hline 72 & - & - & - & - & - \\
\hline 144 & 0,07 & 1,30 & 0,07 & - & - \\
\hline
\end{tabular}


Table G25 OD, pH, dry cell weight and hydrogen production of $5 \mathrm{mM}$ sucrose containing molasses medium by R. capsulatus DSM 1710

\begin{tabular}{|c|c|c|r|c|c|}
\hline Time $(\mathrm{h})$ & $\begin{array}{c}\text { OD } \\
(660 \mathrm{~nm})\end{array}$ & $\begin{array}{c}\text { Dry Cell } \\
\text { Weight } \\
\left(\mathrm{gdcw} / \mathrm{l}_{\mathrm{c}}\right)\end{array}$ & $\mathrm{pH}$ & $\begin{array}{c}\text { Cumulative } \\
\text { Hydrogen } \\
(\mathrm{ml})\end{array}$ & $\begin{array}{c}\text { Cumulative } \\
\text { Hydrogen } \\
\left(1 / 1_{\mathrm{c}}\right)\end{array}$ \\
\hline 0 & 0,30 & 0,17 & 7,32 & 0,00 & 0,00 \\
\hline 24 & 0,75 & 0,41 & 6,62 & 0,94 & 0,02 \\
\hline 72 & 1,04 & 0,57 & 6,246 & 1,88 & 0,04 \\
\hline 96 & 1,15 & 0,63 & 6,177 & 5,64 & 0,11 \\
\hline 120 & 0,94 & 0,52 & 6,054 & 13,16 & 0,26 \\
\hline 144 & 0,92 & 0,51 & 5,96 & 13,16 & 0,26 \\
\hline 168 & 0,83 & 0,45 & 5,927 & 13,16 & 0,26 \\
\hline 192 & 0,82 & 0,45 & 5,73 & 13,16 & 0,26 \\
\hline
\end{tabular}

Table G26 Organic acid concentrations (mM) in $5 \mathrm{mM}$ molasses (sucrose) medium by $R$. capsulatus DSM 1710.

\begin{tabular}{|c|c|c|c|c|c|}
\hline Time (h) & $\begin{array}{c}\text { Acetic } \\
\text { acid (mM) }\end{array}$ & $\begin{array}{c}\text { Lactic acid } \\
(\mathrm{mM})\end{array}$ & $\begin{array}{c}\text { Formic } \\
\text { acid } \\
(\mathrm{mM})\end{array}$ & $\begin{array}{c}\text { Propionic } \\
\text { acid (mM) }\end{array}$ & $\begin{array}{c}\text { Butyric } \\
\text { acid (mM) }\end{array}$ \\
\hline 0 & 0 & 0 & 0 & 0 & 0 \\
\hline 24 & 0,25 & 0,3 & 0,3 & 0 & 0 \\
\hline 48 & 0,5 & 0,3 & 0,4 & 0,9 & 0,1 \\
\hline 96 & 1,4 & 1,4 & 1,5 & 2 & 0,3 \\
\hline 144 & 7,85 & 2,8 & 0,75 & 2,1 & 1,25 \\
\hline
\end{tabular}


Table G27 OD, pH, dry cell weight and hydrogen production of $7.5 \mathrm{mM}$ sucrose containing molasses medium by $R$. capsulatus DSM 1710

\begin{tabular}{|c|c|c|c|c|c|}
\hline Time $(\mathrm{h})$ & $\begin{array}{c}\text { OD } \\
(660 \mathrm{~nm})\end{array}$ & $\begin{array}{c}\text { Dry Cell } \\
\text { Weight } \\
\left(\mathrm{gdcw} / \mathrm{l}_{\mathrm{c}}\right)\end{array}$ & $\mathrm{pH}$ & $\begin{array}{c}\text { Cumulative } \\
\text { Hydrogen } \\
(\mathrm{ml})\end{array}$ & $\begin{array}{c}\text { Cumulative } \\
\text { Hydrogen } \\
\left(1 / 1_{\mathrm{c}}\right)\end{array}$ \\
\hline 0 & 0,41 & 0,23 & 7,184 & 0 & 0,00 \\
\hline 24 & 0,78 & 0,43 & 6,98 & 1,65 & 0,03 \\
\hline 72 & 1,19 & 0,65 & 6,672 & 4,95 & 0,10 \\
\hline 96 & 1,23 & 0,67 & 6,425 & 7,7 & 0,15 \\
\hline 120 & 1,06 & 0,58 & 6,146 & 9,9 & 0,20 \\
\hline 144 & 1,01 & 0,56 & 5,954 & 10,45 & 0,21 \\
\hline 168 & 0,96 & 0,53 & 5,858 & 10,45 & 0,21 \\
\hline 192 & 0,97 & 0,53 & 5,75 & 10,45 & 0,21 \\
\hline
\end{tabular}

Table G28 Organic acid concentrations (mM) in 7.5 mM molasses (sucrose) medium by $R$. capsulatus DSM 1710.

\begin{tabular}{|c|c|c|c|c|c|}
\hline Time (h) & $\begin{array}{c}\text { Acetic } \\
\text { acid (mM) }\end{array}$ & $\begin{array}{c}\text { Lactic acid } \\
(\mathrm{mM})\end{array}$ & $\begin{array}{c}\text { Formic } \\
\text { acid } \\
(\mathrm{mM})\end{array}$ & $\begin{array}{c}\text { Propionic } \\
\text { acid (mM) }\end{array}$ & $\begin{array}{c}\text { Butyric } \\
\text { acid (mM) }\end{array}$ \\
\hline 0 & 0 & 0 & 0 & 0 & 0 \\
\hline 24 & 0,35 & 1,1 & 0,9 & 0 & 0 \\
\hline 48 & 0,1 & 0,3 & 6 & 0,7 & 0,15 \\
\hline 96 & 3,1 & 0,9 & 1 & 1,75 & 0,3 \\
\hline 144 & 8,5 & 1,8 & 0,75 & 0 & 2,5 \\
\hline
\end{tabular}


Table G29 OD, pH, dry cell weight and hydrogen production of $10 \mathrm{mM}$ sucrose containing molasses medium by $R$. capsulatus DSM 1710

\begin{tabular}{|c|c|c|c|c|c|}
\hline Time $(\mathrm{h})$ & $\begin{array}{c}\text { OD } \\
(660 \mathrm{~nm})\end{array}$ & $\begin{array}{c}\text { Dry Cell } \\
\text { Weight } \\
\left(\mathrm{gdcw} / \mathrm{l}_{\mathrm{c}}\right)\end{array}$ & $\mathrm{pH}$ & $\begin{array}{c}\text { Cumulative } \\
\text { Hydrogen } \\
(\mathrm{ml})\end{array}$ & $\begin{array}{c}\text { Cumulative } \\
\text { Hydrogen } \\
\left(1 / 1_{\mathrm{c}}\right)\end{array}$ \\
\hline 0 & 0,40 & 0,22 & 7,195 & 0 & 0,00 \\
\hline 24 & 0,97 & 0,53 & 6,67 & 3.0 & 0,06 \\
\hline 72 & 1,17 & 0,65 & 6,516 & 15,5 & 0,31 \\
\hline 96 & 1,23 & 0,67 & 6,082 & 19,5 & 0,39 \\
\hline 120 & 1,07 & 0,59 & 5,999 & 22,5 & 0,45 \\
\hline 144 & 1,04 & 0,57 & 5,991 & 24,5 & 0,49 \\
\hline 168 & 2,22 & 1,22 & 5,85 & 25 & 0,50 \\
\hline 192 & 0,99 & 0,54 & 5,740 & 25 & 0,50 \\
\hline
\end{tabular}

Table G30 Organic acid concentrations (mM) in $10 \mathrm{mM}$ molasses (sucrose) medium by $R$. capsulatus DSM 1710.

\begin{tabular}{|c|c|c|c|c|c|}
\hline Time (h) & $\begin{array}{c}\text { Acetic } \\
\text { acid (mM) }\end{array}$ & $\begin{array}{c}\text { Lactic acid } \\
(\mathrm{mM})\end{array}$ & $\begin{array}{c}\text { Formic } \\
\text { acid } \\
(\mathrm{mM})\end{array}$ & $\begin{array}{c}\text { Propionic } \\
\text { acid (mM) }\end{array}$ & $\begin{array}{c}\text { Butyric } \\
\text { acid (mM) }\end{array}$ \\
\hline 0 & 0,00 & 0,00 & 0,00 & 0,00 & 0,00 \\
\hline 24 & 0,65 & 0,21 & 2,51 & 0,00 & 0,00 \\
\hline 48 & 2,41 & 0,56 & 5,31 & 1,32 & 0,22 \\
\hline 96 & 3,00 & 1,55 & 0,96 & 1,21 & 1,42 \\
\hline 144 & 4,86 & 0,60 & 0,66 & 0,00 & 3,32 \\
\hline
\end{tabular}


Table G31 OD, pH, dry cell weight and hydrogen production of $5 \mathrm{mM}$ molasses (sucrose) medium by $R$. capsulatus YO3

\begin{tabular}{|c|c|c|c|c|c|}
\hline Time (h) & $\begin{array}{c}\text { OD }(660 \\
\mathrm{nm})\end{array}$ & $\begin{array}{c}\text { Dry Cell } \\
\text { Weight } \\
\left(\mathrm{gdcw} / \mathrm{l}_{\mathrm{c}}\right)\end{array}$ & $\mathrm{pH}$ & $\begin{array}{c}\text { Cumulative } \\
\text { Hydrogen } \\
(\mathrm{ml})\end{array}$ & $\begin{array}{c}\text { Cumulative } \\
\text { Hydrogen } \\
\left(1 / 1_{\mathrm{c}}\right)\end{array}$ \\
\hline 0 & 0,30 & 0,17 & 7,42 & 0 & 0,00 \\
\hline 24 & 0,61 & 0,34 & 6,48 & 13,86 & 0,28 \\
\hline 48 & 1,09 & 0,60 & 6,42 & 20,79 & 0,42 \\
\hline 72 & 1,10 & 0,61 & 6,36 & 33,66 & 0,67 \\
\hline 120 & 1,24 & 0,68 & 6,34 & 34,65 & 0,69 \\
\hline 144 & 2,25 & 1,24 & 6,12 & 34,64 & 0,70 \\
\hline 168 & 2,29 & 1,26 & 5,90 & 35,0 & 0,70 \\
\hline 192 & 2,29 & 1,26 & 5,87 & 35,64 & 0,71 \\
\hline
\end{tabular}

Table G32 Organic acid concentrations in $5 \mathrm{mM}$ molasses (sucrose) medium by $R$. capsulatus YO3

\begin{tabular}{|c|c|c|c|c|c|}
\hline Time (h) & $\begin{array}{c}\text { Acetic } \\
\text { acid (mM) }\end{array}$ & $\begin{array}{c}\text { Lactic acid } \\
(\mathrm{mM})\end{array}$ & $\begin{array}{c}\text { Formic } \\
\text { acid } \\
(\mathrm{mM})\end{array}$ & $\begin{array}{c}\text { Propionic } \\
\text { acid (mM) }\end{array}$ & $\begin{array}{c}\text { Butyric } \\
\text { acid (mM) }\end{array}$ \\
\hline 0 & 0 & 0 & 0 & 0 & 0 \\
\hline 24 & 0,2 & 0,35 & 1,1 & 0 & 0 \\
\hline 48 & 0,1 & 0,2 & 3 & 0,2 & 0 \\
\hline 72 & 0 & 0,1 & 2,6 & 0,4 & 0,1 \\
\hline 96 & 1,95 & 0,15 & 3,65 & 2 & 0 \\
\hline
\end{tabular}


Table G33 OD, pH, dry cell weight and hydrogen production of $7.5 \mathrm{mM}$ molasses (sucrose) medium by $R$. capsulatus YO3

\begin{tabular}{|c|c|c|c|c|c|}
\hline Time (h) & $\begin{array}{c}\text { OD }(660 \\
\mathrm{nm})\end{array}$ & $\begin{array}{c}\text { Dry Cell } \\
\text { Weight } \\
\left(\mathrm{gdcw} / \mathrm{l}_{\mathrm{c}}\right)\end{array}$ & $\mathrm{pH}$ & $\begin{array}{c}\text { Cumulative } \\
\text { Hydrogen } \\
(\mathrm{ml})\end{array}$ & $\begin{array}{c}\text { Cumulative } \\
\text { Hydrogen } \\
\left(1 / 1_{\mathrm{c}}\right)\end{array}$ \\
\hline 0 & 0,28 & 0,15 & 7,32 & 0 & 0,00 \\
\hline 24 & 0,74 & 0,41 & 7,05 & 10,56 & 0,21 \\
\hline 48 & 1,01 & 0,56 & 6,72 & 20,10 & 0,40 \\
\hline 72 & 1,07 & 0,59 & 6,56 & 20,16 & 0,40 \\
\hline 120 & 1,10 & 0,60 & 6,44 & 20,16 & 0,40 \\
\hline 144 & 1,65 & 0,91 & 6,10 & 25,92 & 0,52 \\
\hline 168 & 1,81 & 1,00 & 5,97 & 26,88 & 0,54 \\
\hline 192 & 1,82 & 1,00 & 5,65 & 26,88 & 0,54 \\
\hline
\end{tabular}

Table G34 Organic acid concentrations (mM) in 7.5 mM molasses (sucrose) medium by $R$. capsulatus YO3

\begin{tabular}{|c|c|c|c|c|c|}
\hline Time (h) & $\begin{array}{c}\text { Acetic } \\
\text { acid (mM) }\end{array}$ & $\begin{array}{c}\text { Lactic acid } \\
(\mathrm{mM})\end{array}$ & $\begin{array}{c}\text { Formic } \\
\text { acid } \\
(\mathrm{mM})\end{array}$ & $\begin{array}{c}\text { Propionic } \\
\text { acid (mM) }\end{array}$ & $\begin{array}{c}\text { Butyric } \\
\text { acid (mM) }\end{array}$ \\
\hline 0 & 0 & 0 & 0 & 0 & 0 \\
\hline 24 & 0,5 & 0,6 & 2,1 & 0 & 0 \\
\hline 48 & 0,3 & 0,25 & 3,6 & 0 & 0 \\
\hline 72 & 0,35 & 0,2 & 4,65 & 1 & 0 \\
\hline 96 & 0,2 & 0,1 & 3,85 & 0,8 & 0 \\
\hline
\end{tabular}


Table G35 OD, pH, dry cell weight and hydrogen production of $10 \mathrm{mM}$ molasses (sucrose) medium by $R$. capsulatus YO3

\begin{tabular}{|c|c|c|c|c|c|}
\hline Time (h) & $\begin{array}{c}\text { OD }(660 \\
\mathrm{nm})\end{array}$ & $\begin{array}{c}\text { Dry Cell } \\
\text { Weight } \\
\left(\mathrm{gdcw} / \mathrm{l}_{\mathrm{c}}\right)\end{array}$ & $\mathrm{pH}$ & $\begin{array}{c}\text { Cumulative } \\
\text { Hydrogen } \\
(\mathrm{ml})\end{array}$ & $\begin{array}{c}\text { Cumulative } \\
\text { Hydrogen } \\
\left(1 / 1_{\mathrm{c}}\right)\end{array}$ \\
\hline 0 & 0,30 & 0,17 & 7,32 & 0 & 0,00 \\
\hline 24 & 0,90 & 0,49 & 7,05 & 1,8 & 0,04 \\
\hline 48 & 1,25 & 0,69 & 6,72 & 3,6 & 0,07 \\
\hline 72 & 1,42 & 0,78 & 6,56 & 4,8 & 0,10 \\
\hline 120 & 1,86 & 1,02 & 6,44 & 6,5 & 0,13 \\
\hline 144 & 2,11 & 1,16 & 6,10 & 12 & 0,24 \\
\hline 168 & 2,14 & 1,18 & 5,97 & 13,8 & 0,28 \\
\hline 192 & 2,13 & 1,17 & 5,65 & 15,6 & 0,31 \\
\hline
\end{tabular}

Table G36 Organic acid concentrations (mM) in $10 \mathrm{mM}$ molasses (sucrose) medium by $R$. capsulatus YO3

\begin{tabular}{|c|c|c|c|c|c|}
\hline Time (h) & $\begin{array}{c}\text { Acetic } \\
\text { acid (mM) }\end{array}$ & $\begin{array}{c}\text { Lactic acid } \\
(\mathrm{mM})\end{array}$ & $\begin{array}{c}\text { Formic } \\
\text { acid } \\
(\mathrm{mM})\end{array}$ & $\begin{array}{c}\text { Propionic } \\
\text { acid (mM) }\end{array}$ & $\begin{array}{c}\text { Butyric } \\
\text { acid (mM) }\end{array}$ \\
\hline 0 & 0 & 0 & 0 & 0 & 0 \\
\hline 24 & 0,8 & 0,9 & 3,7 & 0,1 & 0 \\
\hline 48 & 0,15 & 0,35 & 5,5 & 0 & 0 \\
\hline 72 & 0,5 & 0,15 & 6,4 & 0,5 & 0 \\
\hline 96 & 0,1 & 0 & 3,5 & 0,7 & 0 \\
\hline
\end{tabular}


Table G37 OD, pH, dry cell weight and hydrogen production of $5 \mathrm{mM}$ molasses (sucrose) medium by $R$. palustris (DSM 127)

\begin{tabular}{|c|c|c|c|c|c|}
\hline Time (h) & $\begin{array}{c}\text { OD }(660 \\
\mathrm{nm})\end{array}$ & $\begin{array}{c}\text { Dry Cell } \\
\text { Weight } \\
\left(\mathrm{gdcw} / \mathrm{l}_{\mathrm{c}}\right)\end{array}$ & $\mathrm{pH}$ & $\begin{array}{c}\text { Cumulative } \\
\text { Hydrogen } \\
(\mathrm{ml})\end{array}$ & $\begin{array}{c}\text { Cumulative } \\
\text { Hydrogen } \\
\left(1 / 1_{\mathrm{c}}\right)\end{array}$ \\
\hline 0 & 0,20 & 0,05 & 7,40 & 0,00 & 0,00 \\
\hline 24 & 0,58 & 0,15 & 7,10 & 11,70 & 0,23 \\
\hline 48 & 0,54 & 0,14 & 6,75 & 33,30 & 0,67 \\
\hline 72 & 0,78 & 0,20 & 6,59 & 44,10 & 0,88 \\
\hline 120 & 0,93 & 0,24 & 6,72 & 44,70 & 0,89 \\
\hline 144 & 1,12 & 0,29 & 6,65 & 46,50 & 0,93 \\
\hline 168 & 1,02 & 0,26 & 6,53 & 49,50 & 0,99 \\
\hline 192 & 0,64 & 0,17 & 6,36 & 53,70 & 1,07 \\
\hline
\end{tabular}

Table G38 Organic acid concentrations (mM) in $5 \mathrm{mM}$ molasses (sucrose) medium by $R$. palustris (DSM 127)

\begin{tabular}{|c|c|c|c|c|c|}
\hline Time (h) & $\begin{array}{c}\text { Acetic } \\
\text { acid (mM) }\end{array}$ & $\begin{array}{c}\text { Lactic acid } \\
(\mathrm{mM})\end{array}$ & $\begin{array}{c}\text { Formic } \\
\text { acid } \\
(\mathrm{mM})\end{array}$ & $\begin{array}{c}\text { Propionic } \\
\text { acid (mM) }\end{array}$ & $\begin{array}{c}\text { Butyric } \\
\text { acid (mM) }\end{array}$ \\
\hline 0 & 0,97 & 1,04 & 3,15 & - & - \\
\hline 72 & - & - & - & - & - \\
\hline 144 & 1,62 & 0,92 & 6,88 & - & - \\
\hline
\end{tabular}


Table G39 OD, $\mathrm{pH}$, dry cell weight and hydrogen production of $7.5 \mathrm{mM}$ molasses (sucrose) medium by $R$. palustris (DSM 127)

\begin{tabular}{|c|c|c|c|c|c|}
\hline Time (h) & $\begin{array}{c}\text { OD }(660 \\
\mathrm{nm})\end{array}$ & $\begin{array}{c}\text { Dry Cell } \\
\text { Weight } \\
\left(\mathrm{gdcw} / \mathrm{l}_{\mathrm{c}}\right)\end{array}$ & $\mathrm{pH}$ & $\begin{array}{c}\text { Cumulative } \\
\text { Hydrogen } \\
(\mathrm{ml})\end{array}$ & $\begin{array}{c}\text { Cumulative } \\
\text { Hydrogen } \\
\left(1 / 1_{\mathrm{c}}\right)\end{array}$ \\
\hline 0 & 0,17 & 0,04 & 7,31 & 0,00 & 0,00 \\
\hline 24 & 0,72 & 0,19 & 7,04 & 14,40 & 0,29 \\
\hline 48 & 0,64 & 0,17 & 6,77 & 36,90 & 0,74 \\
\hline 72 & 1,01 & 0,26 & 6,51 & 37,50 & 0,75 \\
\hline 120 & 1,03 & 0,27 & 6,98 & 45,30 & 0,91 \\
\hline 144 & 1,17 & 0,30 & 6,54 & 54,30 & 1,09 \\
\hline 168 & 1,08 & 0,28 & 6,43 & 57,30 & 1,15 \\
\hline 192 & 0,82 & 0,21 & 6,36 & 62,10 & 1,24 \\
\hline
\end{tabular}

Table G40 Organic acid concentrations (mM) in 7.5 mM molasses (sucrose) medium by $R$. palustris (DSM 127)

\begin{tabular}{|c|c|c|c|c|c|}
\hline Time (h) & $\begin{array}{c}\text { Acetic } \\
\text { acid (mM) }\end{array}$ & $\begin{array}{c}\text { Lactic acid } \\
(\mathrm{mM})\end{array}$ & $\begin{array}{c}\text { Formic } \\
\text { acid } \\
(\mathrm{mM})\end{array}$ & $\begin{array}{c}\text { Propionic } \\
\text { acid (mM) }\end{array}$ & $\begin{array}{c}\text { Butyric } \\
\text { acid (mM) }\end{array}$ \\
\hline 0 & 1,43 & 1,34 & 4,23 & 0,03 & - \\
\hline 72 & - & - & - & - & - \\
\hline 144 & 1,25 & 0,81 & 9,37 & 0,00 & - \\
\hline
\end{tabular}


Table G41 OD, pH, dry cell weight and hydrogen production of $10 \mathrm{mM}$ molasses (sucrose) medium by $R$. palustris (DSM 127)

\begin{tabular}{|c|r|r|r|r|r|}
\hline Time (h) & \multicolumn{1}{|c|}{$\begin{array}{c}\text { OD }(660 \\
\mathrm{nm})\end{array}$} & \multicolumn{1}{|c|}{$\begin{array}{c}\text { Dry Cell } \\
\text { Weight } \\
\left(\mathrm{gdcw} / \mathrm{l}_{\mathrm{c}}\right)\end{array}$} & \multicolumn{1}{c|}{$\mathrm{pH}$} & \multicolumn{1}{c|}{$\begin{array}{c}\text { Cumulative } \\
\text { Hydrogen } \\
(\mathrm{ml})\end{array}$} & $\begin{array}{c}\text { Cumulative } \\
\text { Hydrogen } \\
\left(1 / 1_{\mathrm{c}}\right)\end{array}$ \\
\hline 0 & 0,21 & 0,05 & 7,44 & 0,00 & 0,00 \\
\hline 24 & 1,07 & 0,28 & 6,95 & 19,80 & 0,40 \\
\hline 48 & 0,97 & 0,25 & 6,36 & 30,60 & 0,61 \\
\hline 72 & 1,33 & 0,35 & 6,15 & 43,80 & 0,88 \\
\hline 120 & 1,44 & 0,37 & 6,09 & 55,20 & 1,10 \\
\hline 144 & 1,53 & 0,40 & 6,24 & 63,60 & 1,27 \\
\hline 168 & 1,43 & 0,37 & 5,98 & 66,60 & 1,33 \\
\hline 192 & 1,35 & 0,35 & 5,86 & 69,60 & 1,39 \\
\hline
\end{tabular}

Table G42 Organic acid concentrations (mM) in $10 \mathrm{mM}$ molasses (sucrose) medium by $R$. palustris (DSM 127)

\begin{tabular}{|c|c|c|c|c|c|}
\hline Time (h) & $\begin{array}{c}\text { Acetic } \\
\text { acid (mM) }\end{array}$ & $\begin{array}{c}\text { Lactic acid } \\
(\mathrm{mM})\end{array}$ & $\begin{array}{c}\text { Formic } \\
\text { acid } \\
(\mathrm{mM})\end{array}$ & $\begin{array}{c}\text { Propionic } \\
\text { acid (mM) }\end{array}$ & $\begin{array}{c}\text { Butyric } \\
\text { acid (mM) }\end{array}$ \\
\hline 0 & 0,69 & 1,15 & 3,73 & 0,00 & - \\
\hline 72 & - & - & - & - & - \\
\hline 144 & 6,54 & 5,37 & 3,74 & 0,05 & - \\
\hline
\end{tabular}


Table G43 OD, pH, dry cell weight and hydrogen production of $5 \mathrm{mM}$ sucrose containing molasses medium by $R$. sphaeroides O.U.001

\begin{tabular}{|c|c|c|c|c|c|}
\hline Time (h) & $\begin{array}{c}\text { OD } \\
(660 \mathrm{~nm})\end{array}$ & $\begin{array}{c}\text { Dry Cell } \\
\text { Weight } \\
\left(\mathrm{gdcw} / \mathrm{l}_{\mathrm{c}}\right)\end{array}$ & $\mathrm{pH}$ & $\begin{array}{c}\text { Cumulative } \\
\text { Hydrogen } \\
(\mathrm{ml})\end{array}$ & $\begin{array}{c}\text { Cumulative } \\
\text { Hydrogen } \\
\left(1 / 1_{\mathrm{c}}\right)\end{array}$ \\
\hline 0 & 0,25 & 0,14 & 7,25 & 0,00 & 0,00 \\
\hline 24 & - & - & - & - & - \\
\hline 48 & 0,99 & 0,54 & 7,22 & 7,00 & 0,14 \\
\hline 72 & 1,24 & 0,68 & 6,97 & 10,00 & 0,20 \\
\hline 96 & 1,31 & 0,72 & 6,20 & 22,00 & 0,44 \\
\hline 120 & 0,70 & 0,39 & 6,16 & 28,00 & 0,56 \\
\hline 144 & 0,95 & 0,52 & 6,00 & 30,00 & 0,60 \\
\hline 180 & 0,52 & 0,29 & 5,98 & 33,00 & 0,66 \\
\hline
\end{tabular}

Table G44 Organic acid concentrations (mM) in $5 \mathrm{mM}$ molasses (sucrose) medium by $R$. sphaeroides O.U.001

\begin{tabular}{|c|c|c|c|c|c|}
\hline Time (h) & $\begin{array}{c}\text { Acetic } \\
\text { acid (mM) }\end{array}$ & $\begin{array}{c}\text { Lactic acid } \\
(\mathrm{mM})\end{array}$ & $\begin{array}{c}\text { Formic } \\
\text { acid } \\
(\mathrm{mM})\end{array}$ & $\begin{array}{c}\text { Propionic } \\
\text { acid (mM) }\end{array}$ & $\begin{array}{c}\text { Butyric } \\
\text { acid (mM) }\end{array}$ \\
\hline 0 & 0,24 & 0,41 & 0,96 & 0,00 & - \\
\hline 72 & 0,08 & 0,00 & 0,00 & 0,00 & - \\
\hline 144 & 3,30 & 2,37 & 5,37 & 0,25 & - \\
\hline
\end{tabular}


Table G45 OD, pH, dry cell weight and hydrogen production of $7.5 \mathrm{mM}$ sucrose containing molasses medium by $R$. sphaeroides O.U.001

\begin{tabular}{|c|c|c|c|c|c|}
\hline Time (h) & $\begin{array}{c}\text { OD } \\
(660 \mathrm{~nm})\end{array}$ & $\begin{array}{c}\text { Dry Cell } \\
\text { Weight } \\
\left(\mathrm{gdcw} / \mathrm{l}_{\mathrm{c}}\right)\end{array}$ & $\mathrm{pH}$ & $\begin{array}{c}\text { Cumulative } \\
\text { Hydrogen } \\
(\mathrm{ml})\end{array}$ & $\begin{array}{c}\text { Cumulative } \\
\text { Hydrogen } \\
\left(1 / 1_{\mathrm{c}}\right)\end{array}$ \\
\hline 0 & 0,21 & 0,12 & 7,25 & 0,00 & 0,00 \\
\hline 24 & - & - & - & - & - \\
\hline 48 & 1,38 & 0,76 & 6,73 & 7,00 & 0,14 \\
\hline 72 & 1,07 & 0,59 & 6,61 & 9,00 & 0,18 \\
\hline 96 & 1,11 & 0,61 & 6,53 & 10,00 & 0,20 \\
\hline 120 & 1,20 & 0,66 & 6,60 & 15,00 & 0,30 \\
\hline 144 & 1,10 & 0,61 & 6,42 & 18,00 & 0,36 \\
\hline 180 & 1,12 & 0,62 & 6,38 & 20,00 & 0,40 \\
\hline
\end{tabular}

Table G46 Organic acid concentrations $(\mathrm{mM})$ in $7.5 \mathrm{mM}$ molasses (sucrose) medium by $R$. sphaeroides O.U.001

\begin{tabular}{|c|c|c|c|c|c|}
\hline Time (h) & $\begin{array}{c}\text { Acetic } \\
\text { acid (mM) }\end{array}$ & $\begin{array}{c}\text { Lactic acid } \\
(\mathrm{mM})\end{array}$ & $\begin{array}{c}\text { Formic } \\
\text { acid } \\
(\mathrm{mM})\end{array}$ & $\begin{array}{c}\text { Propionic } \\
\text { acid (mM) }\end{array}$ & $\begin{array}{c}\text { Butyric } \\
\text { acid (mM) }\end{array}$ \\
\hline 0 & 0,36 & 0,59 & 1,51 & 0,04 & - \\
\hline 72 & 0,78 & 0,03 & 7,56 & 0,00 & - \\
\hline 144 & 0,78 & 1,07 & 11,41 & 0,02 & - \\
\hline
\end{tabular}


Table G47 OD, pH, dry cell weight and hydrogen production of $7.5 \mathrm{mM}$ sucrose containing molasses medium by $R$. sphaeroides O.U.001

\begin{tabular}{|c|c|c|c|c|c|}
\hline Time (h) & $\begin{array}{c}\text { OD } \\
(660 \mathrm{~nm})\end{array}$ & $\begin{array}{c}\text { Dry Cell } \\
\text { Weight } \\
\left(\mathrm{gdcw} / \mathrm{l}_{\mathrm{c}}\right)\end{array}$ & $\mathrm{pH}$ & $\begin{array}{c}\text { Cumulative } \\
\text { Hydrogen } \\
(\mathrm{ml})\end{array}$ & $\begin{array}{c}\text { Cumulative } \\
\text { Hydrogen } \\
\left(1 / 1_{\mathrm{c}}\right)\end{array}$ \\
\hline 0 & 0,27 & 0,15 & 7,22 & 0,00 & 0,00 \\
\hline 24 & - & - & - & - & - \\
\hline 48 & 1,21 & 0,67 & 7,14 & 7,00 & 0,14 \\
\hline 72 & 1,25 & 0,69 & 7,19 & 11,00 & 0,22 \\
\hline 96 & 1,50 & 0,83 & 7,21 & 15,00 & 0,30 \\
\hline 120 & 1,30 & 0,72 & 7,01 & 23,00 & 0,46 \\
\hline 144 & 1,32 & 0,73 & 6,98 & 27,00 & 0,54 \\
\hline 180 & 1,30 & 0,72 & 6,82 & 30,00 & 0,60 \\
\hline
\end{tabular}

Table G48 Organic acid concentrations (mM) in $10 \mathrm{mM}$ molasses (sucrose) medium by $R$. sphaeroides O.U.001

\begin{tabular}{|c|c|c|c|c|c|}
\hline Time (h) & $\begin{array}{c}\text { Acetic } \\
\text { acid (mM) }\end{array}$ & $\begin{array}{c}\text { Lactic acid } \\
(\mathrm{mM})\end{array}$ & $\begin{array}{c}\text { Formic } \\
\text { acid } \\
(\mathrm{mM})\end{array}$ & $\begin{array}{c}\text { Propionic } \\
\text { acid (mM) }\end{array}$ & $\begin{array}{c}\text { Butyric } \\
\text { acid (mM) }\end{array}$ \\
\hline 0 & 1,13 & 1,22 & 3,42 & 0,09 & - \\
\hline 72 & 0,41 & 0,06 & 0,00 & 0,00 & - \\
\hline 144 & 0,31 & 0,03 & 4,94 & 0,00 & - \\
\hline
\end{tabular}


G49-G53 Experimental data for co-cultivation studies in $150 \mathrm{ml}$ bioreactors.

Table G49 OD, $\mathrm{pH}$, dry cell weight and hydrogen production of $5 \mathrm{mM}$ molasses sucrose medium by $R$. palustris (DSM 127)

\begin{tabular}{|c|r|r|r|r|c|}
\hline Time (h) & OD $(660 \mathrm{~nm})$ & $\begin{array}{c}\text { Dry Cell } \\
\text { Weight } \\
\left(\mathrm{gdcw} / \mathbf{l}_{\mathrm{c}}\right)\end{array}$ & \multicolumn{1}{c|}{$\mathrm{pH}$} & $\begin{array}{c}\text { Cumulative } \\
\text { Hydrogen }(\mathrm{ml})\end{array}$ & $\begin{array}{c}\text { Cumulative } \\
\text { Hydrogen } \\
\left(1 / \mathrm{c}_{\mathrm{c}}\right)\end{array}$ \\
\hline 0 & 0,21 & 0,05 & 7,29 & 0,0 & 0,0 \\
\hline 24 & 0,41 & 0,11 & 7,16 & 28,8 & 0,2 \\
\hline 48 & 0,42 & 0,11 & 6,81 & 109,8 & 0,7 \\
\hline 72 & 0,64 & 0,17 & 6,74 & 156,6 & 1,0 \\
\hline 120 & 0,75 & 0,20 & 6,67 & 198,9 & 1,3 \\
\hline 144 & 0,95 & 0,25 & 6,56 & 227,7 & 1,5 \\
\hline 168 & 0,80 & 0,21 & 6,63 & 242,1 & 1,6 \\
\hline 192 & 0,77 & 0,20 & 6,48 & 260,1 & 1,7 \\
\hline
\end{tabular}

Table G50 OD, pH, dry cell weight and hydrogen production of $5 \mathrm{mM}$ molasses sucrose medium by $R$. capsulatus YO3 (Hup-)

\begin{tabular}{|c|r|r|r|r|r|}
\hline Time (h) & OD $(660 \mathrm{~nm})$ & $\begin{array}{c}\text { Dry Cell } \\
\text { Weight } \\
\left(\mathrm{gdcw} / l_{\mathrm{c}}\right)\end{array}$ & \multicolumn{1}{c|}{$\mathrm{pH}$} & $\begin{array}{c}\text { Cumulative } \\
\text { Hydrogen }(\mathrm{ml})\end{array}$ & $\begin{array}{c}\text { Cumulative } \\
\text { Hydrogen } \\
\left(1 / l_{\mathrm{c}}\right)\end{array}$ \\
\hline 0 & 0,22 & 0,10 & 7,34 & 0 & 0 \\
\hline 24 & 0,33 & 0,15 & 7,23 & 21,6 & 0,144 \\
\hline 48 & 0,37 & 0,16 & 6,91 & 80,1 & 0,534 \\
\hline 72 & 0,61 & 0,27 & 6,79 & 98,1 & 0,654 \\
\hline 120 & 0,61 & 0,27 & 6,81 & 117,9 & 0,786 \\
\hline 144 & 0,69 & 0,31 & 6,75 & 130,5 & 0,87 \\
\hline 168 & 0,42 & 0,19 & 6,64 & 134,1 & 0,894 \\
\hline 192 & 0,47 & 0,21 & 6,52 & 137,7 & 0,918 \\
\hline
\end{tabular}


Table G51 OD, pH, dry cell weight and hydrogen production on $5 \mathrm{mM}$ molasses sucrose medium by the co-cultivation of $R$. palustris (DSM 127) and $R$. capsulatus YO3 (Hup-)

\begin{tabular}{|c|c|c|c|c|c|}
\hline Time (h) & OD $(660 \mathrm{~nm})$ & $\begin{array}{c}\text { Dry Cell } \\
\text { Weight } \\
\left(\mathrm{gdcw} / \mathrm{l}_{\mathrm{c}}\right)\end{array}$ & $\mathrm{pH}$ & $\begin{array}{c}\text { Cumulative } \\
\text { Hydrogen }(\mathrm{ml})\end{array}$ & $\begin{array}{c}\text { Cumulative } \\
\text { Hydrogen } \\
\left(1 / \mathrm{l}_{\mathrm{c}}\right)\end{array}$ \\
\hline 0 & 0,22 & 0,10 & 7,34 & 0 & 0 \\
\hline 24 & 0,33 & 0,15 & 7,23 & 21,6 & 0,144 \\
\hline 48 & 0,37 & 0,16 & 6,91 & 80,1 & 0,534 \\
\hline 72 & 0,61 & 0,27 & 6,79 & 98,1 & 0,654 \\
\hline 120 & 0,61 & 0,27 & 6,81 & 117,9 & 0,786 \\
\hline 144 & 0,69 & 0,31 & 6,75 & 130,5 & 0,87 \\
\hline 168 & 0,42 & 0,19 & 6,64 & 134,1 & 0,894 \\
\hline 192 & 0,47 & 0,21 & 6,52 & 137,7 & 0,918 \\
\hline
\end{tabular}

Table G52 OD, $\mathrm{pH}$, dry cell weight and hydrogen production of $5 \mathrm{mM}$ molasses sucrose medium by $R$. sphaeroides O.U.001

\begin{tabular}{|c|c|c|c|c|c|}
\hline Time (h) & OD $(660 \mathrm{~nm})$ & $\begin{array}{c}\text { Dry Cell } \\
\text { Weight } \\
\left(\mathrm{gdcw} / \mathrm{l}_{\mathrm{c}}\right)\end{array}$ & $\mathrm{pH}$ & $\begin{array}{c}\text { Cumulative } \\
\text { Hydrogen }(\mathrm{ml})\end{array}$ & $\begin{array}{c}\text { Cumulative } \\
\text { Hydrogen } \\
\left(1 / /_{\mathrm{c}}\right)\end{array}$ \\
\hline 0 & 0,25 & - & 7,37 & 0,00 & 0,00 \\
\hline 24 & 0,73 & - & 7,38 & 2,00 & 0,01 \\
\hline 48 & 0,75 & - & 7,12 & 28,00 & 0,19 \\
\hline 72 & 0,74 & - & 6,95 & 58,00 & 0,39 \\
\hline 120 & 1,01 & - & 6,70 & 64,00 & 0,43 \\
\hline 168 & 1,05 & - & 6,59 & 64,00 & 0,43 \\
\hline 216 & 1,18 & - & 6,46 & 68,00 & 0,45 \\
\hline 240 & 1,17 & - & 6,46 & 68,00 & 0,45 \\
\hline
\end{tabular}


Table G53 OD, pH, dry cell weight and hydrogen production of $5 \mathrm{mM}$ molasses sucrose medium by $R$. palustris (DSM 127)

\begin{tabular}{|c|c|c|c|c|c|}
\hline Time (h) & $\begin{array}{c}\text { OD }(660 \\
\mathrm{nm})\end{array}$ & $\begin{array}{c}\text { Dry Cell } \\
\text { Weight } \\
\left(\mathrm{gdcw} / \mathrm{l}_{\mathrm{c}}\right)\end{array}$ & $\mathrm{pH}$ & $\begin{array}{c}\text { Cumulative } \\
\text { Hydrogen } \\
(\mathrm{ml})\end{array}$ & $\begin{array}{c}\text { Cumulative } \\
\text { Hydrogen } \\
\left(1 / \mathrm{l}_{\mathrm{c}}\right)\end{array}$ \\
\hline 0 & 0,19 & 0,05 & 7,35 & 0,00 & 0,00 \\
\hline 24 & 0,64 & 0,17 & 6,29 & 48,00 & 0,32 \\
\hline 48 & 0,53 & 0,14 & 6,00 & 84,00 & 0,56 \\
\hline 72 & 0,60 & 0,16 & 6,01 & 124,00 & 0,83 \\
\hline 120 & 0,88 & 0,23 & 5,93 & 172,00 & 1,15 \\
\hline 168 & 0,85 & 0,22 & 5,85 & 177,00 & 1,18 \\
\hline 216 & 0,91 & 0,24 & 5,54 & 178,00 & 1,19 \\
\hline 240 & 0,92 & 0,24 & 5,55 & 178,00 & 1,19 \\
\hline
\end{tabular}


Table G53 OD, pH, dry cell weight and hydrogen production of the co-cultivation of $R$. sphaeroides O.U.001 and R. palustris (DSM 127) on $5 \mathrm{mM}$ molasses sucrose medium.

\begin{tabular}{|c|r|r|r|r|r|}
\hline Time (h) & \multicolumn{1}{|c|}{$\begin{array}{c}\text { OD }(660 \\
\mathrm{nm})\end{array}$} & $\begin{array}{c}\text { Dry Cell } \\
\text { Weight } \\
\left(\mathrm{gdcw} / \mathrm{l}_{\mathrm{c}}\right)\end{array}$ & \multicolumn{1}{c|}{$\mathrm{pH}$} & \multicolumn{1}{c|}{$\begin{array}{c}\text { Cumulative } \\
\text { Hydrogen } \\
(\mathrm{ml})\end{array}$} & $\begin{array}{c}\text { Cumulative } \\
\text { Hydrogen } \\
\left(1 / \mathrm{l}_{\mathrm{c}}\right)\end{array}$ \\
\hline 0 & 0,21 & - & 7,33 & 0,00 & 0,00 \\
\hline 24 & 0,68 & - & 6,57 & 40,00 & 0,27 \\
\hline 48 & 0,57 & - & 6,46 & 64,00 & 0,43 \\
\hline 72 & 0,58 & - & 6,22 & 96,00 & 0,64 \\
\hline 120 & 0,95 & - & 6,06 & 136,00 & 0,91 \\
\hline 168 & 1,08 & - & 6,03 & 148,00 & 0,99 \\
\hline 216 & 1,12 & - & 5,93 & 176,00 & 1,17 \\
\hline 240 & 1,11 & - & 5,94 & 176,00 & 1,17 \\
\hline
\end{tabular}




\section{APPENDIX H}

H1-H24. Organic Acid Concentrations of PNS Bacteria on Different Sucrose and Molasses Media with Different Sucrose Concentrations in $50 \mathrm{ml}$ bioreactors.

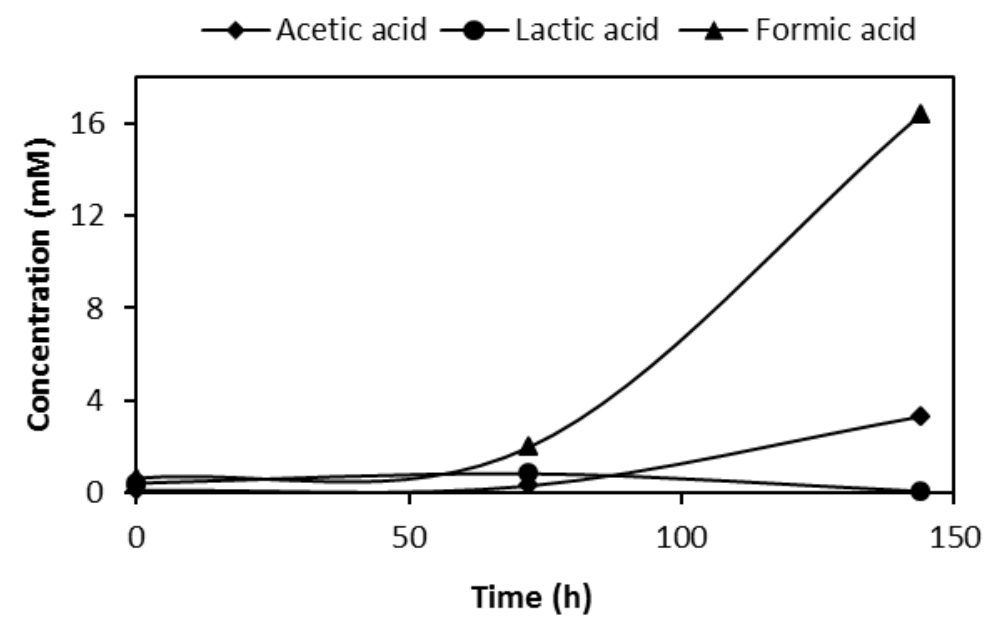

Figure H1 Concentrations of organic acids in photofermentation of R.capsulatus DSM 1710 on $5 \mathrm{mM}$ sucrose hydrogen production media. 


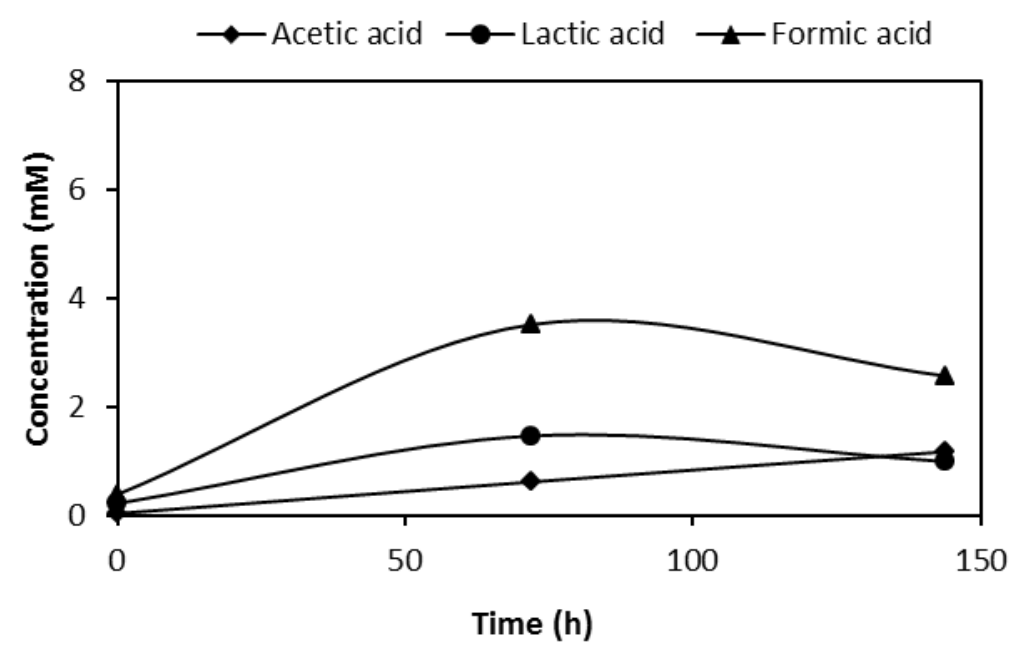

Figure H2 Concentrations of organic acids in photofermentation of R.capsulatus DSM 1710 on $7.5 \mathrm{mM}$ sucrose hydrogen production media.

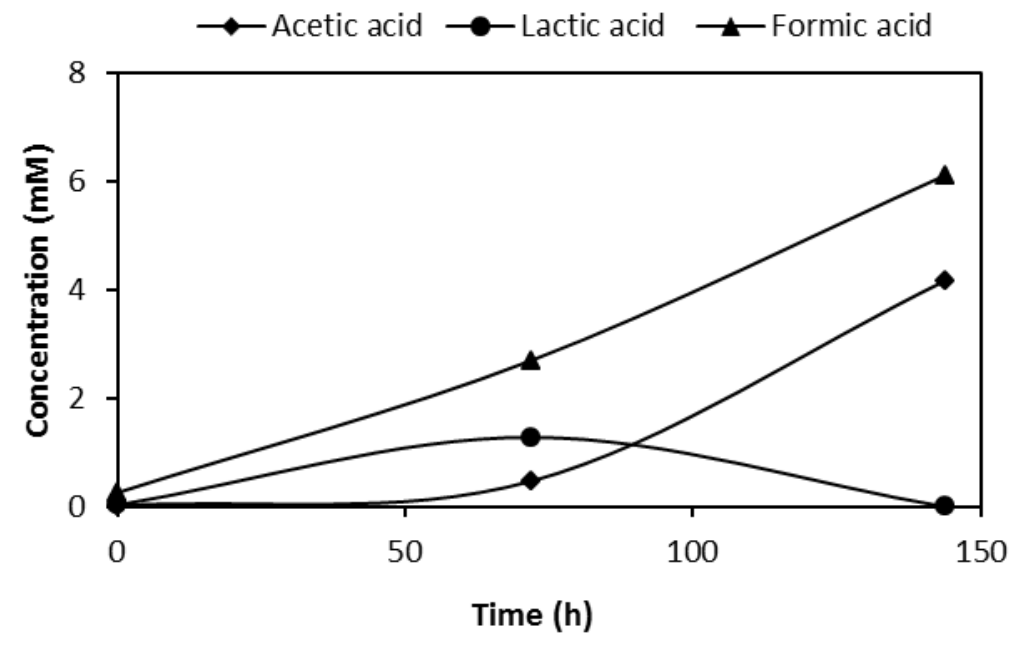

Figure H3 Concentrations of organic acids in photofermentation of R.capsulatus DSM 1710 on $10 \mathrm{mM}$ sucrose hydrogen production media. 


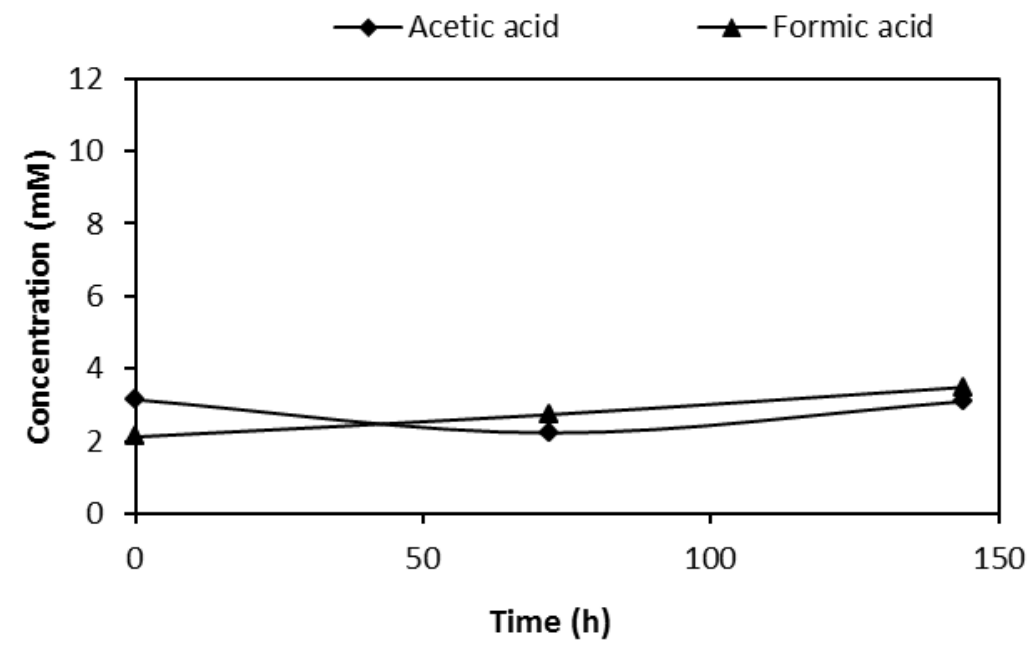

Figure H4 Concentrations of organic acids in photofermentation of R.capsulatus YO3 (Hup ${ }^{-}$) on $5 \mathrm{mM}$ sucrose hydrogen production media.

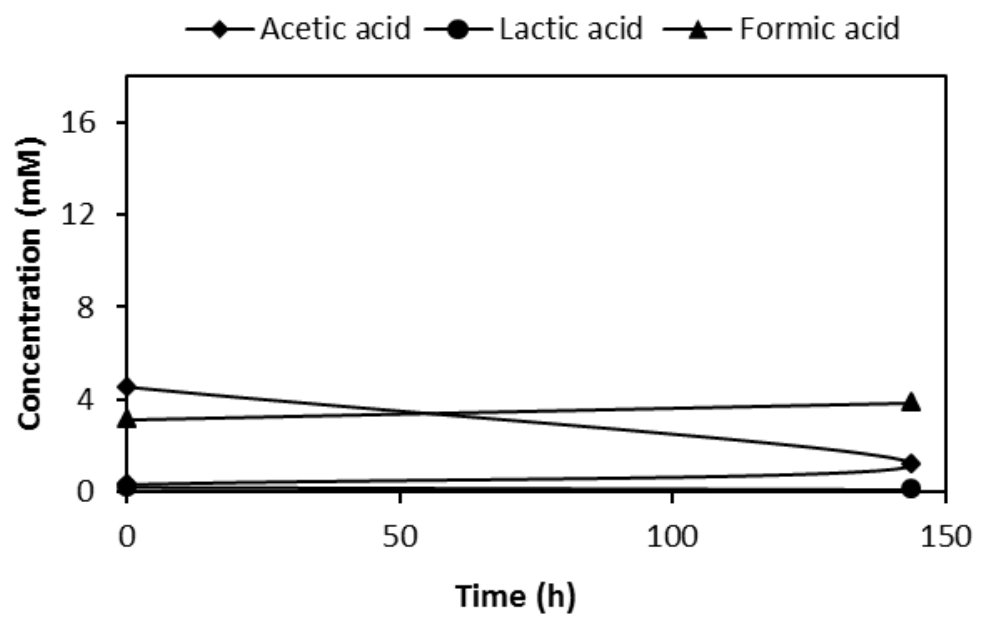

Figure H5 Concentrations of organic acids in photofermentation of R.capsulatus YO3 (Hup ${ }^{-}$) on $7.5 \mathrm{mM}$ sucrose hydrogen production media. 


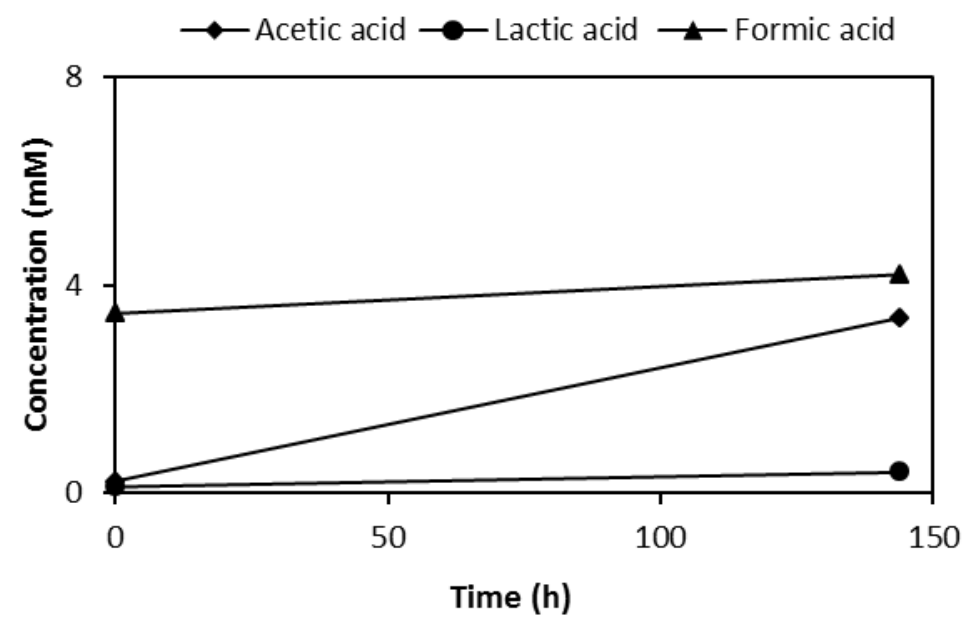

Figure H6 Concentrations of organic acids in photofermentation of R.capsulatus YO3 (Hup-) on $10 \mathrm{mM}$ sucrose hydrogen production media.

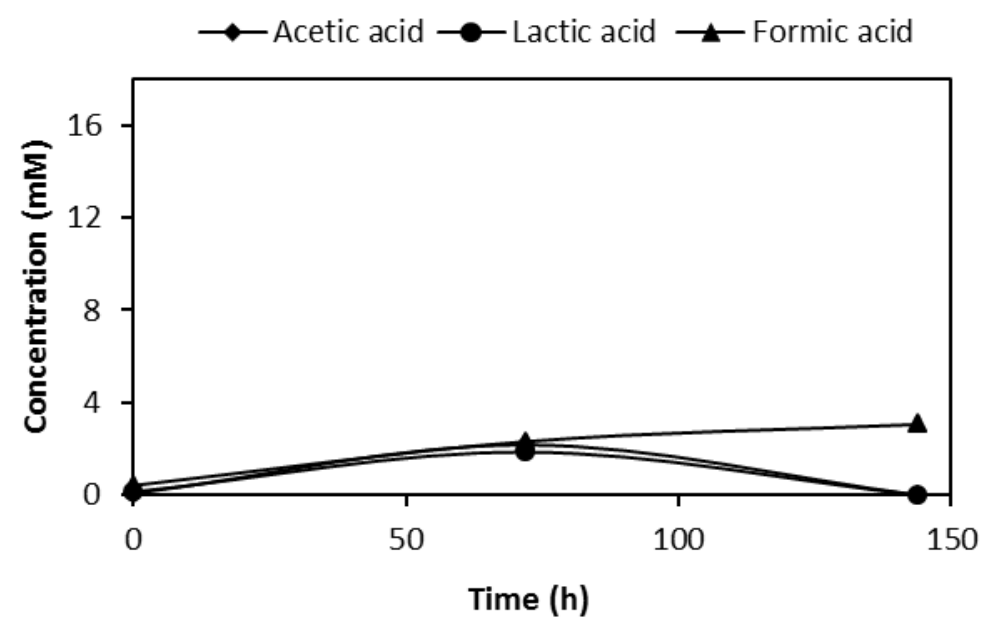

Figure $\mathrm{H} 7$ Concentrations of organic acids in photofermentation of $R$. palustris (DSM 127) on $5 \mathrm{mM}$ sucrose hydrogen production media. 


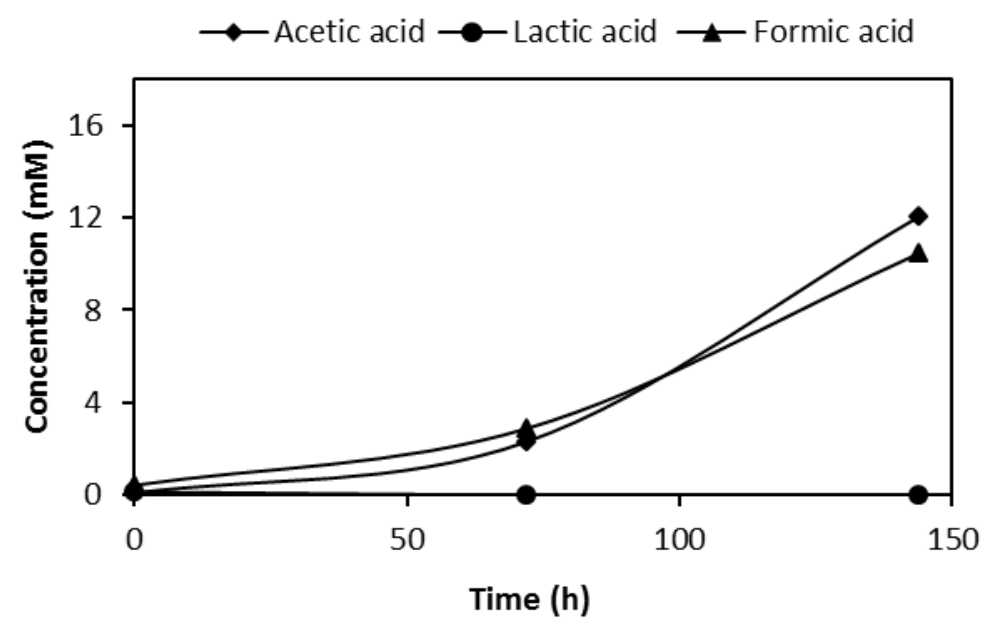

Figure H8 Concentrations of organic acids in photofermentation of $R$. palustris (DSM 127) on $7.5 \mathrm{mM}$ sucrose hydrogen production media.

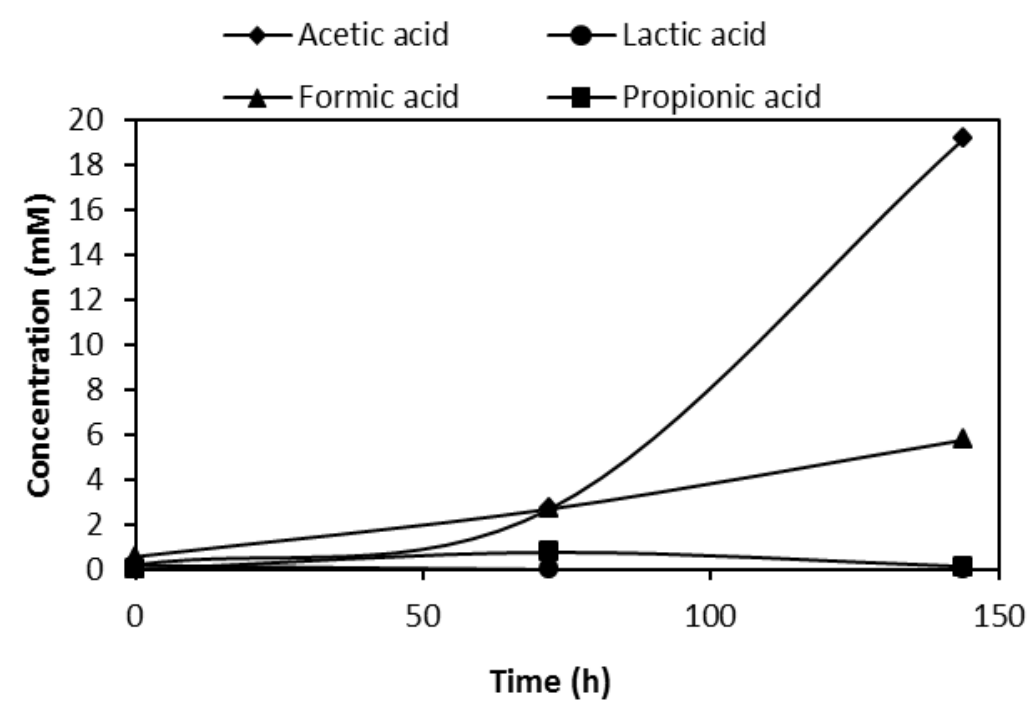

Figure H9 Concentrations of organic acids in photofermentation of $R$. palustris (DSM 127) on $10 \mathrm{mM}$ sucrose hydrogen production media. 


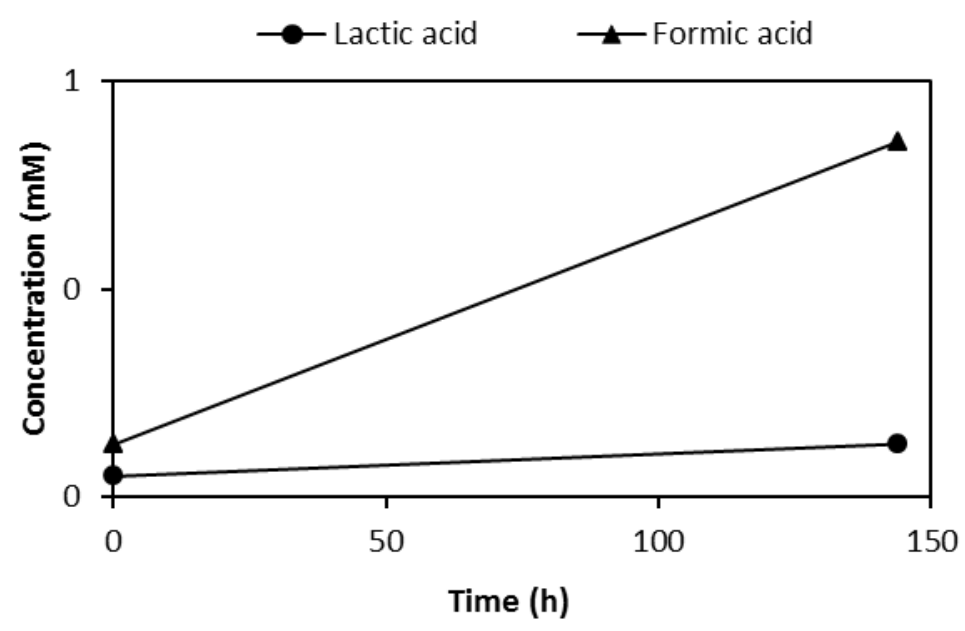

Figure H10 Concentrations of organic acids in photofermentation of $R$. sphaeroides O.U.001 on $5 \mathrm{mM}$ sucrose hydrogen production media.

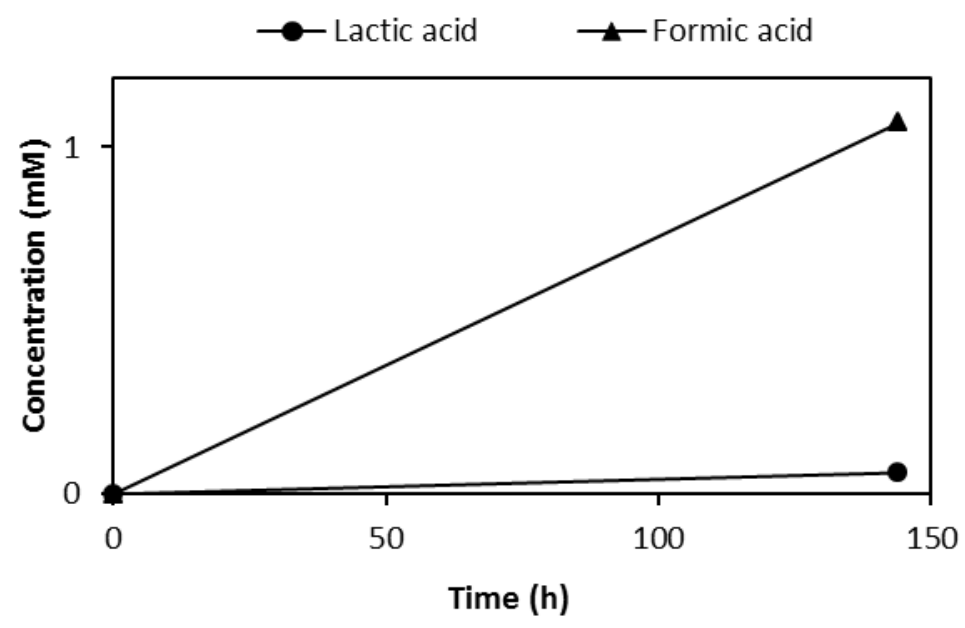

Figure H11 Concentrations of organic acids in photofermentation of $R$. sphaeroides O.U.001 on $7.5 \mathrm{mM}$ sucrose hydrogen production media. 


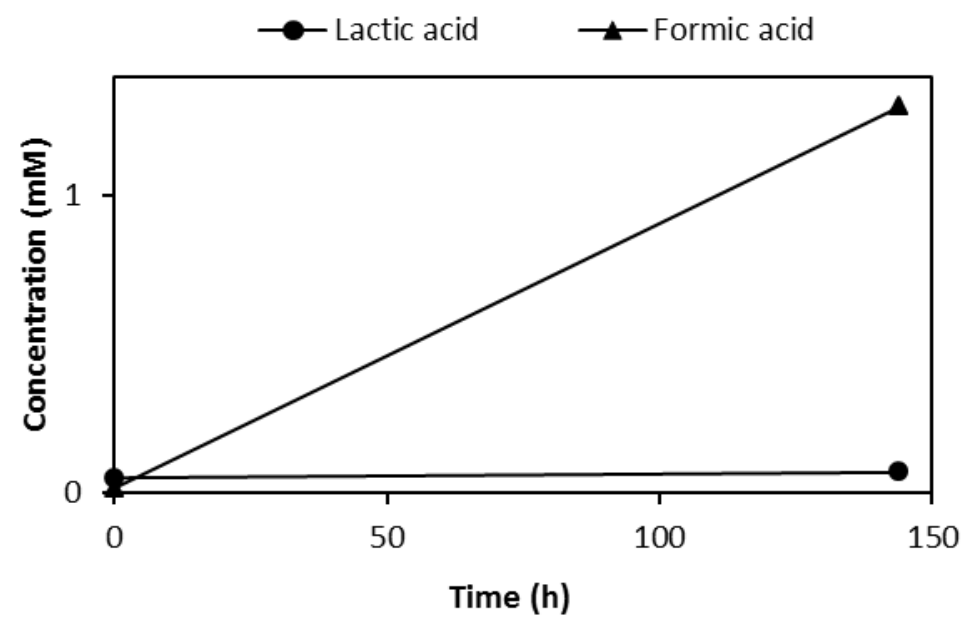

Figure H12 Concentrations of organic acids in photofermentation of $R$. sphaeroides O.U.001 on $10 \mathrm{mM}$ sucrose hydrogen production media.

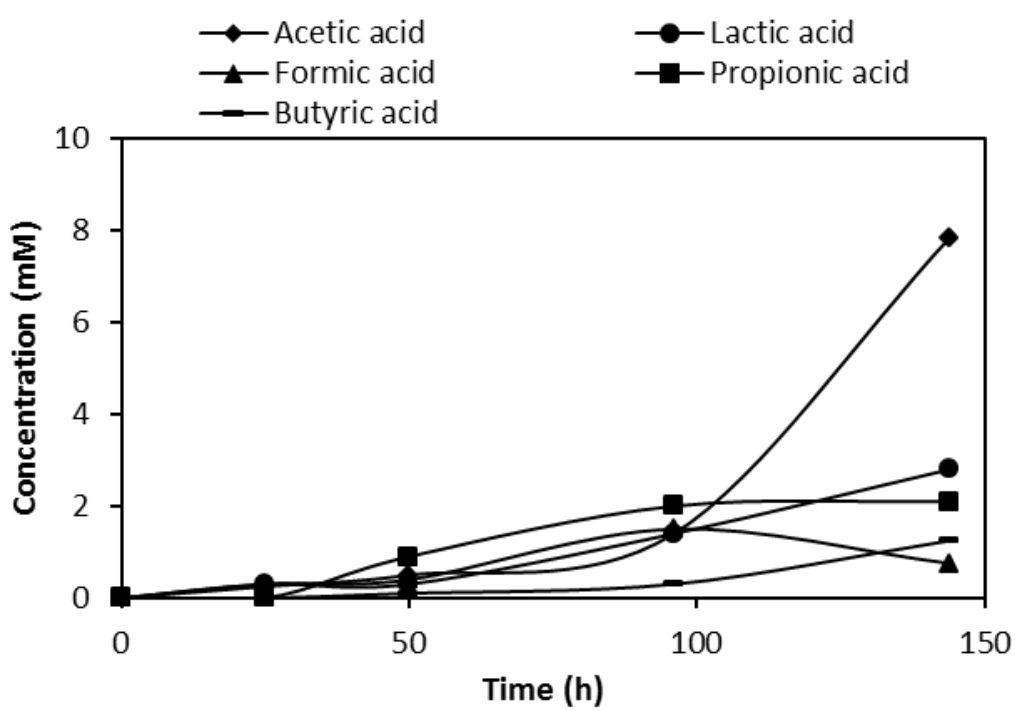

Figure H13 Concentrations of organic acids in photofermentation of $R$. capsulatus DSM 1710 on molasses medium with $5 \mathrm{mM}$ sucrose hydrogen production media. 


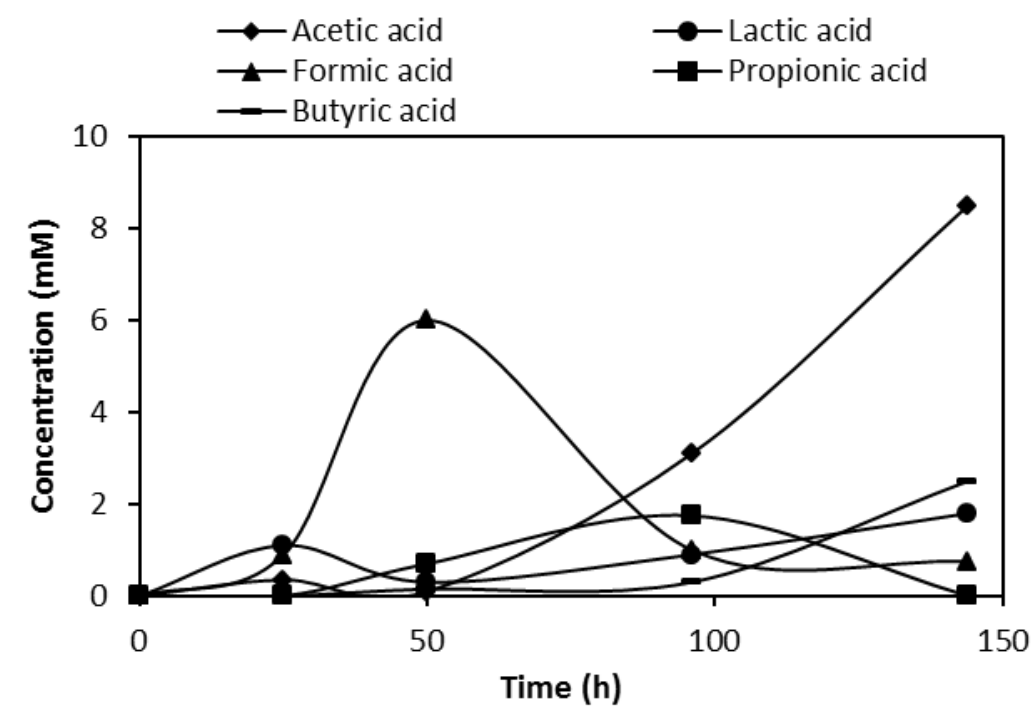

Figure H14 Concentrations of organic acids in photofermentation of $R$. capsulatus DSM 1710 on molasses medium with $7.5 \mathrm{mM}$ sucrose hydrogen production media.

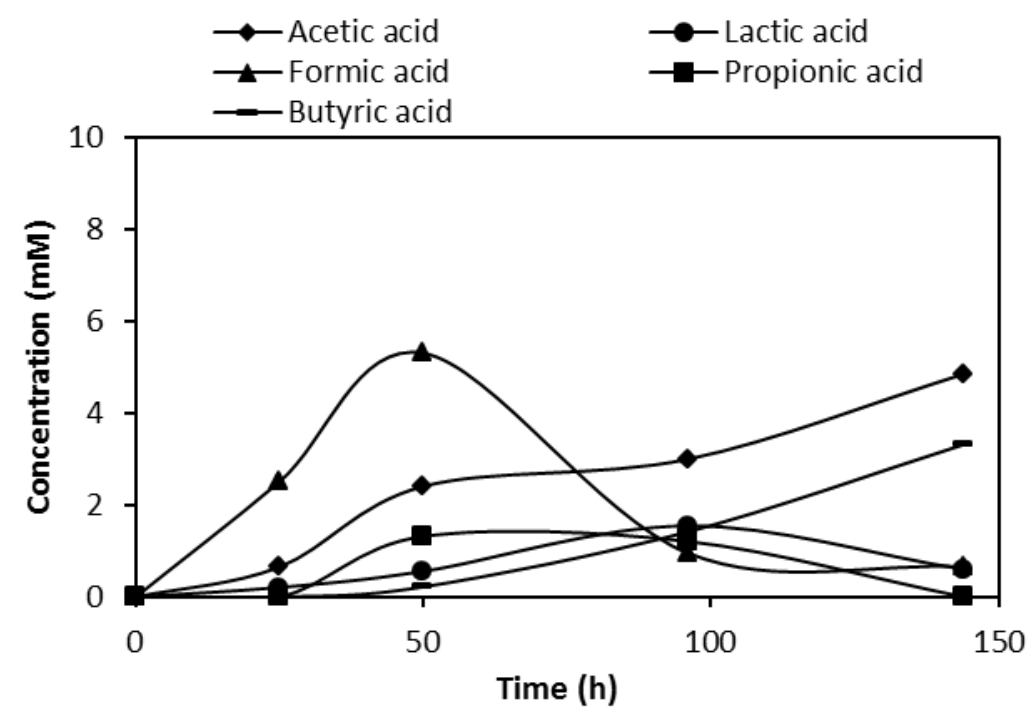

Figure H15 Concentrations of organic acids in photofermentation of $R$. capsulatus (DSM 1710) on molasses medium with $10 \mathrm{mM}$ sucrose hydrogen production media. 


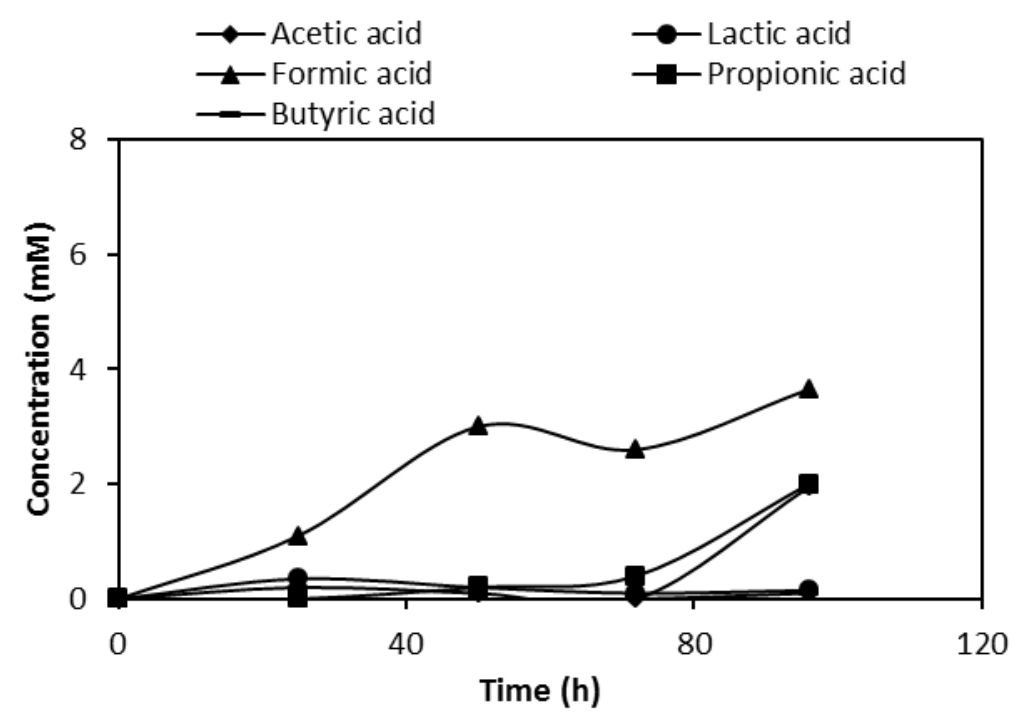

Figure H16 Concentrations of organic acids in photofermentation of $R$. capsulatus YO3 (Hup-) on molasses medium with $5 \mathrm{mM}$ sucrose hydrogen production media.

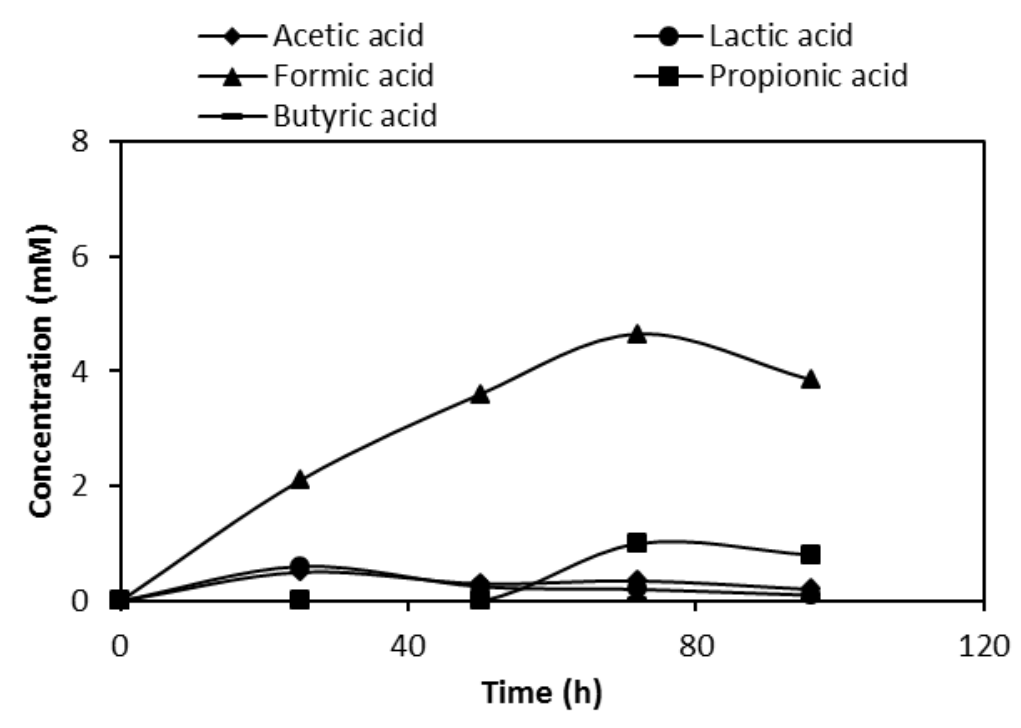

Figure H17 Concentrations of organic acids in photofermentation of $R$. capsulatus YO3 (Hup-) on molasses medium with $7.5 \mathrm{mM}$ sucrose hydrogen production media. 


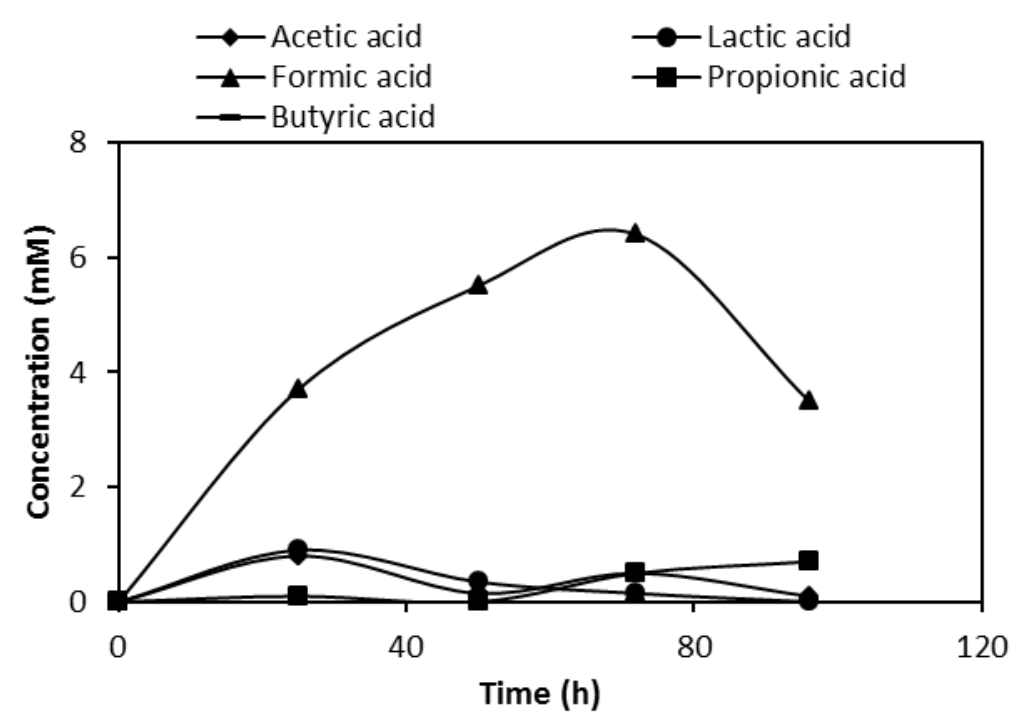

Figure H18 Concentrations of organic acids in photofermentation of $R$. capsulatus YO3 (Hup-) on molasses medium with $10 \mathrm{mM}$ sucrose hydrogen production media.

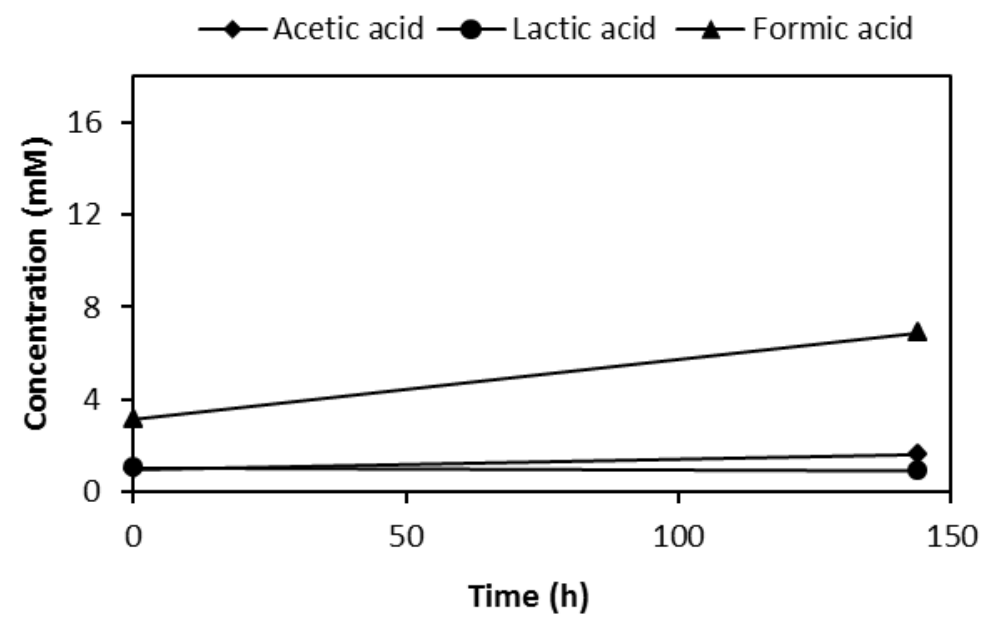

Figure H19 Concentrations of organic acids in photofermentation of $R$. palustris (DSM 127) on molasses medium with $5 \mathrm{mM}$ sucrose hydrogen production media. 


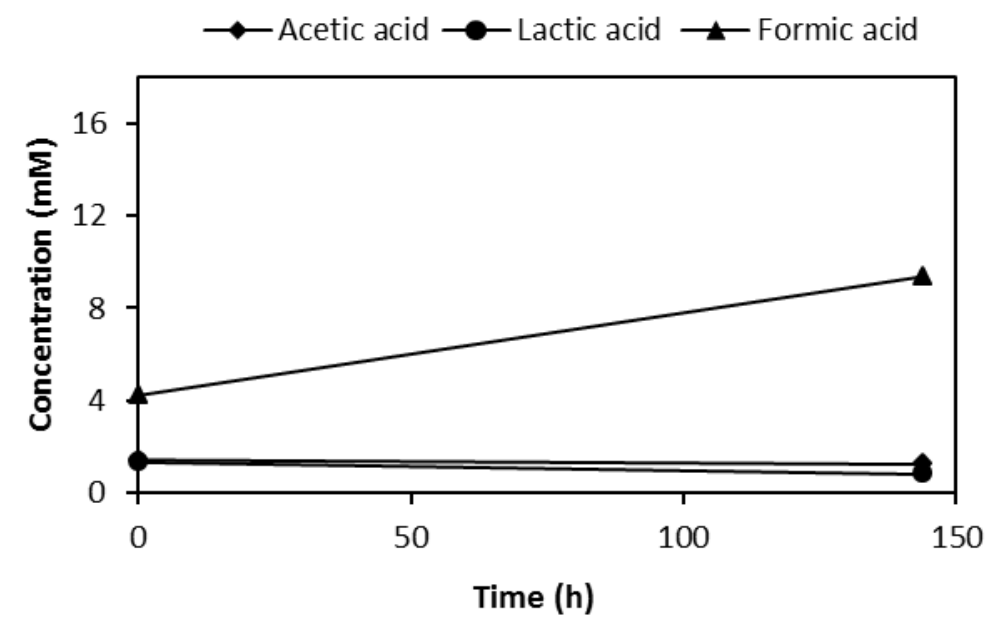

Figure H20 Concentrations of organic acids in photofermentation of $R$. palustris (DSM 127) on molasses medium with $7.5 \mathrm{mM}$ sucrose hydrogen production media.

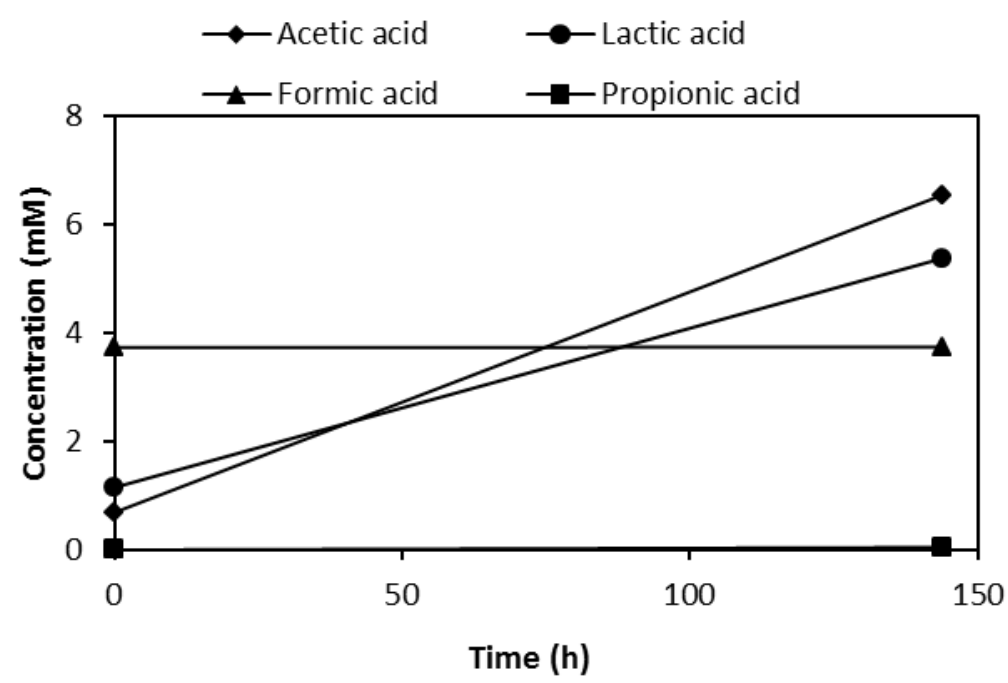

Figure $\mathrm{H} 21$ Concentrations of organic acids in photofermentation of $R$. palustris (DSM 127) on molasses medium with $10 \mathrm{mM}$ sucrose hydrogen production media. 


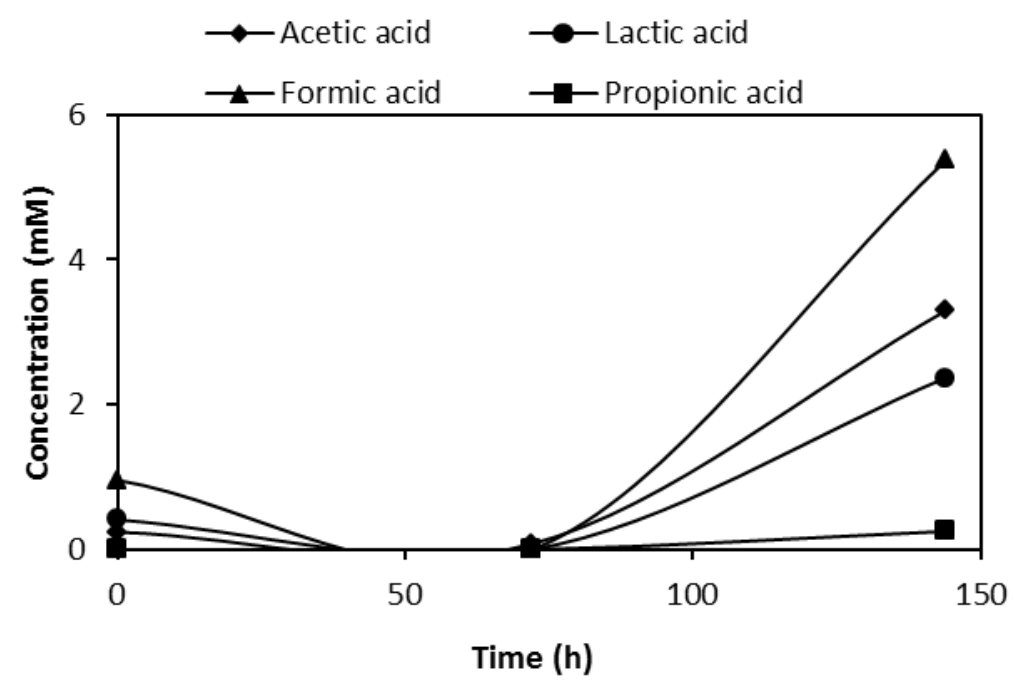

Figure $\mathrm{H} 22$ Concentrations of organic acids in photofermentation of $R$. sphaeroides O.U.001 on molasses medium with $5 \mathrm{mM}$ sucrose hydrogen production media.

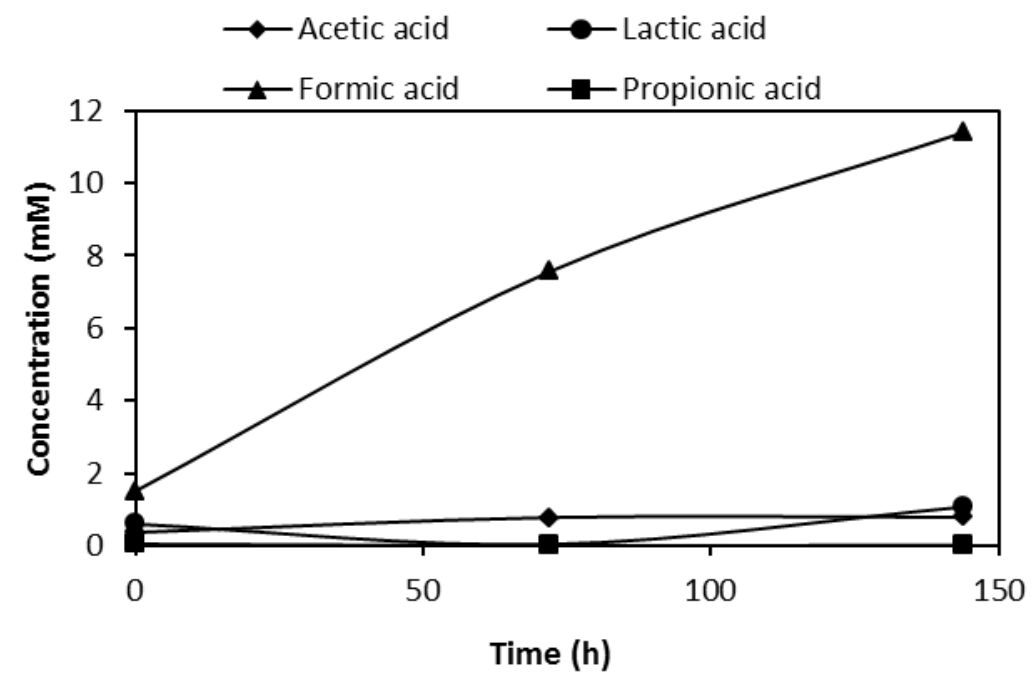

Figure H23 Concentrations of organic acids in photofermentation of $R$. sphaeroides O.U.001 on molasses medium with $7.5 \mathrm{mM}$ sucrose hydrogen production media. 


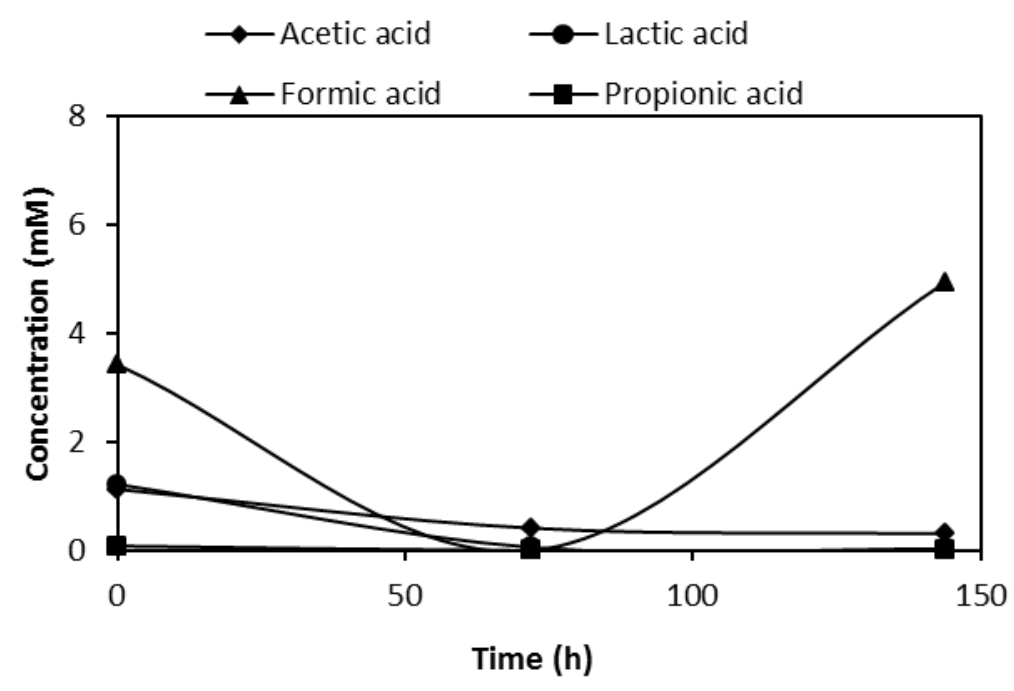

Figure H24 Concentrations of organic acids in photofermentation of $R$. sphaeroides O.U.001 on molasses medium with $10 \mathrm{mM}$ sucrose hydrogen production media. 
Figure H25-H33. Concentrations of organic acids of co-cultivation studies of PNS bacteria in $150 \mathrm{ml}$ bioreactors.

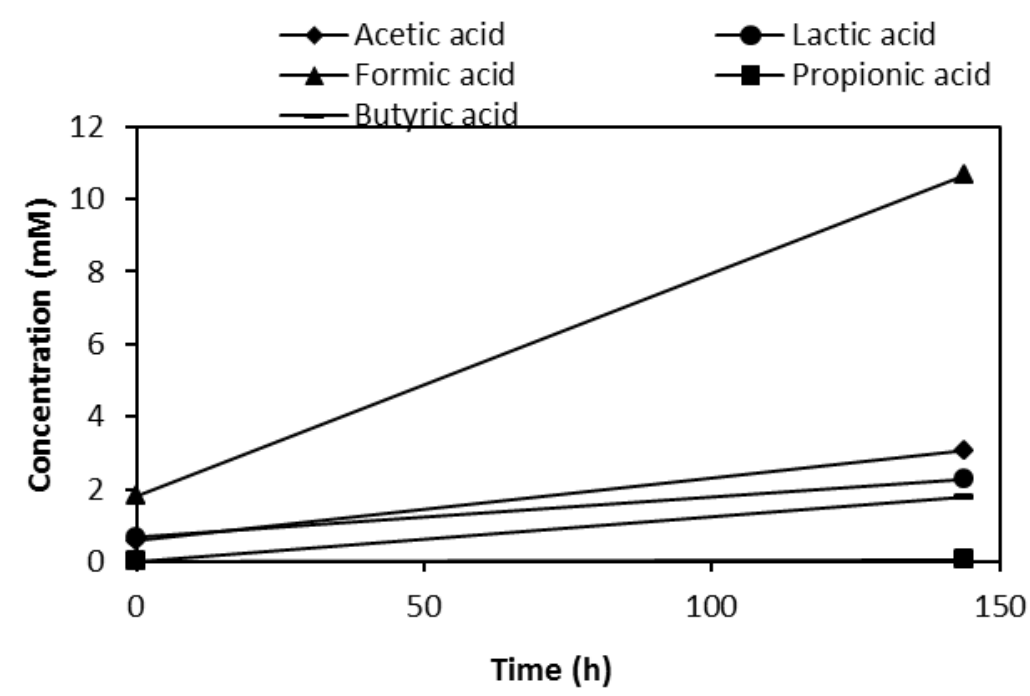

Figure $\mathrm{H} 25$ Concentrations of organic acids in photofermentation of $R$. palustris (DSM 127) on molasses medium with $5 \mathrm{mM}$ sucrose hydrogen production media

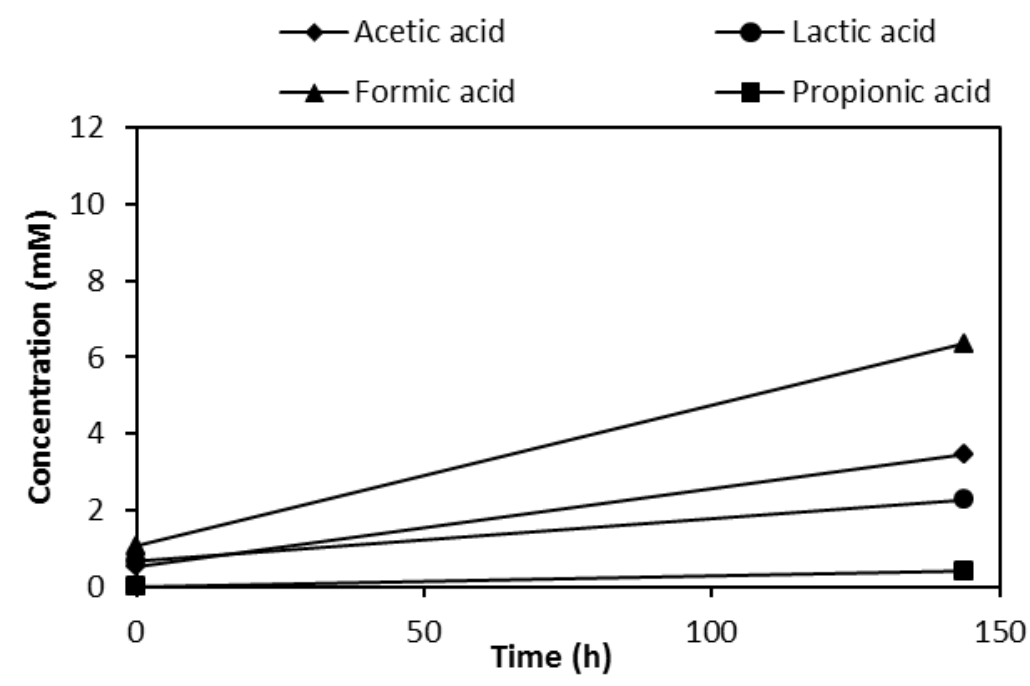

Figure H26 Concentrations of organic acids in photofermentation of $R$. capsulatus YO3 (Hup-) on molasses medium with $5 \mathrm{mM}$ sucrose hydrogen production media. 


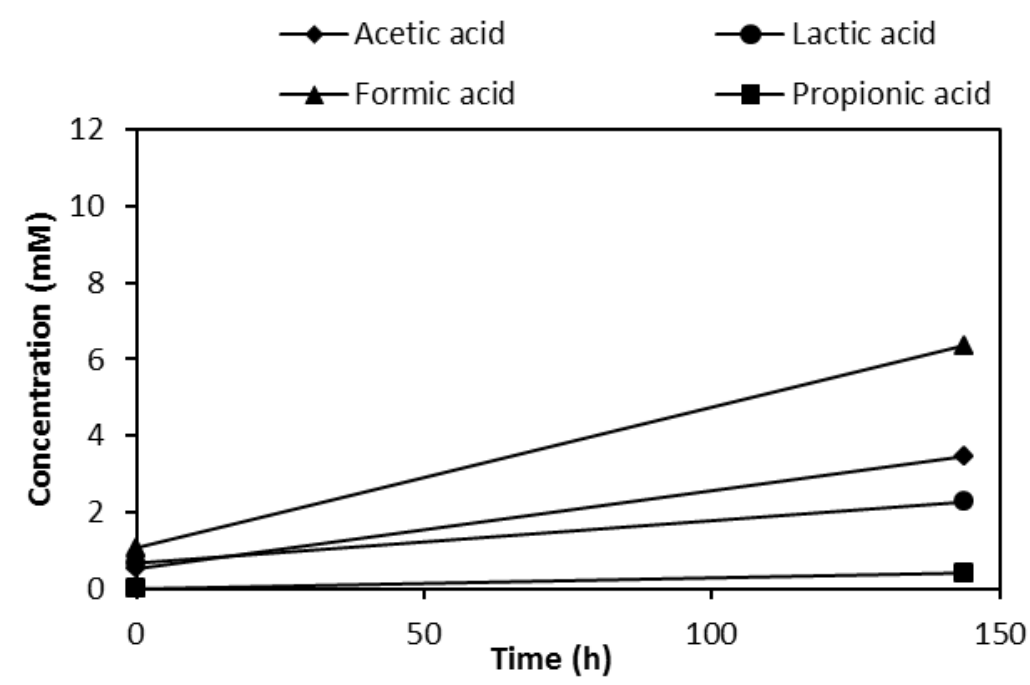

Figure $\mathrm{H} 27$ Concentrations of organic acids in photofermentation of the cocultivation of $R$. palustris (DSM 127) and $R$. capsulatus YO3 (Hup-) on molasses medium with $5 \mathrm{mM}$ sucrose hydrogen production media.

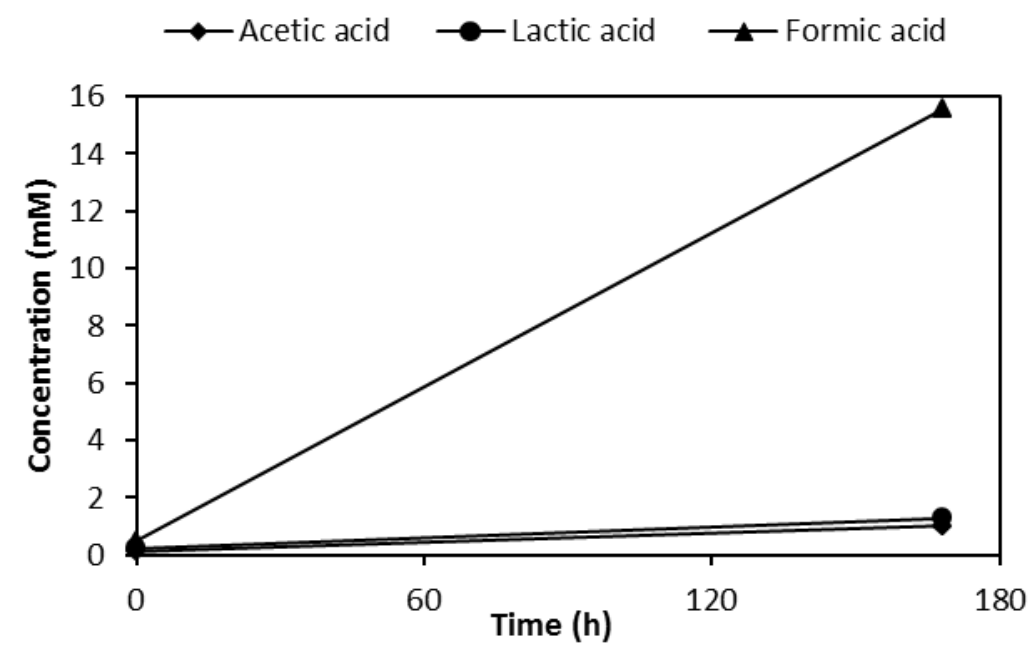

Figure $\mathrm{H} 28$ Concentrations of organic acids in photofermentation of $R$. sphaeroides O.U.001 on molasses medium with $5 \mathrm{mM}$ sucrose hydrogen production media. 


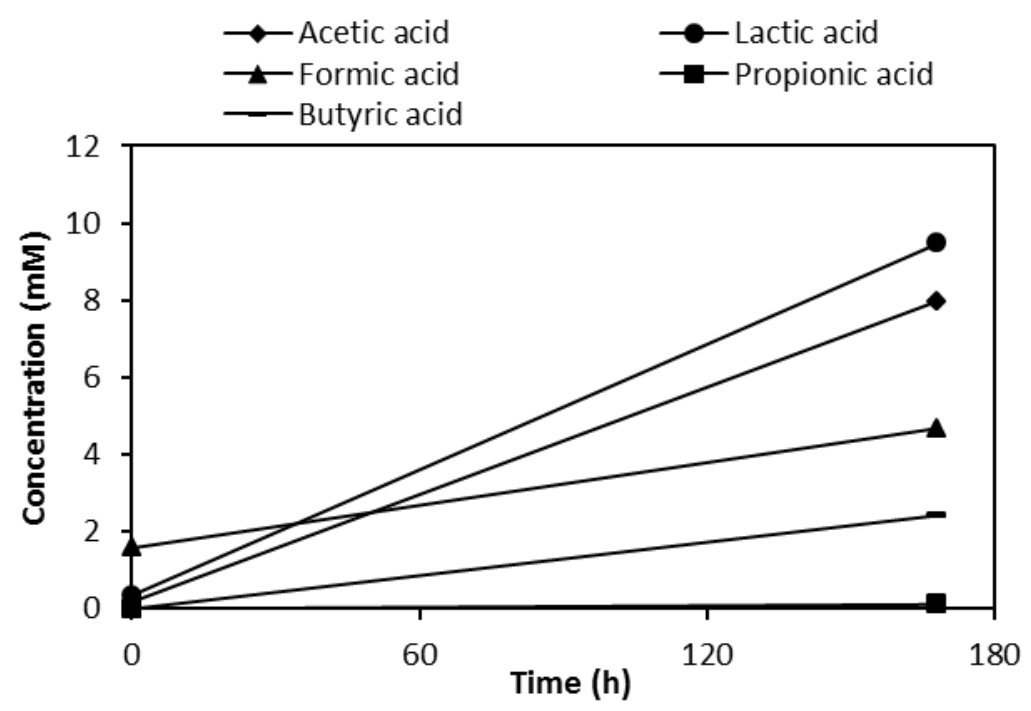

Figure $\mathrm{H} 29$ Concentrations of organic acids in photofermentation of $R$. palustris (DSM 127) on molasses medium with $5 \mathrm{mM}$ sucrose hydrogen production media.

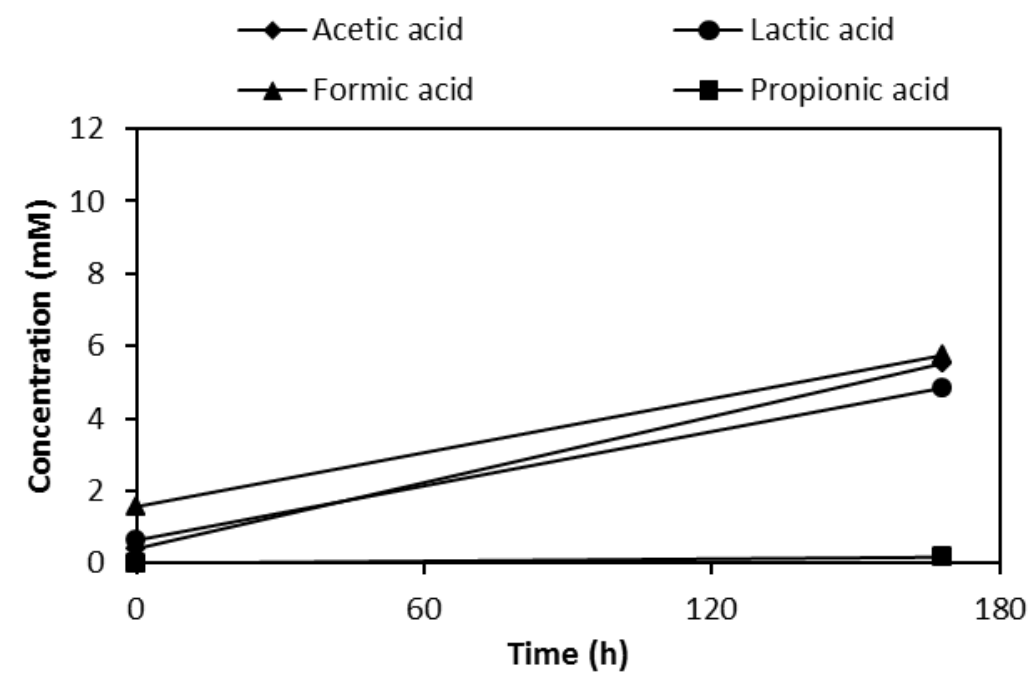

Figure H30 Concentrations of organic acids in photofermentation of the cocultivation of $R$. palustris (DSM 127) and $R$. sphaeroides on molasses medium with $5 \mathrm{mM}$ sucrose hydrogen production media. 


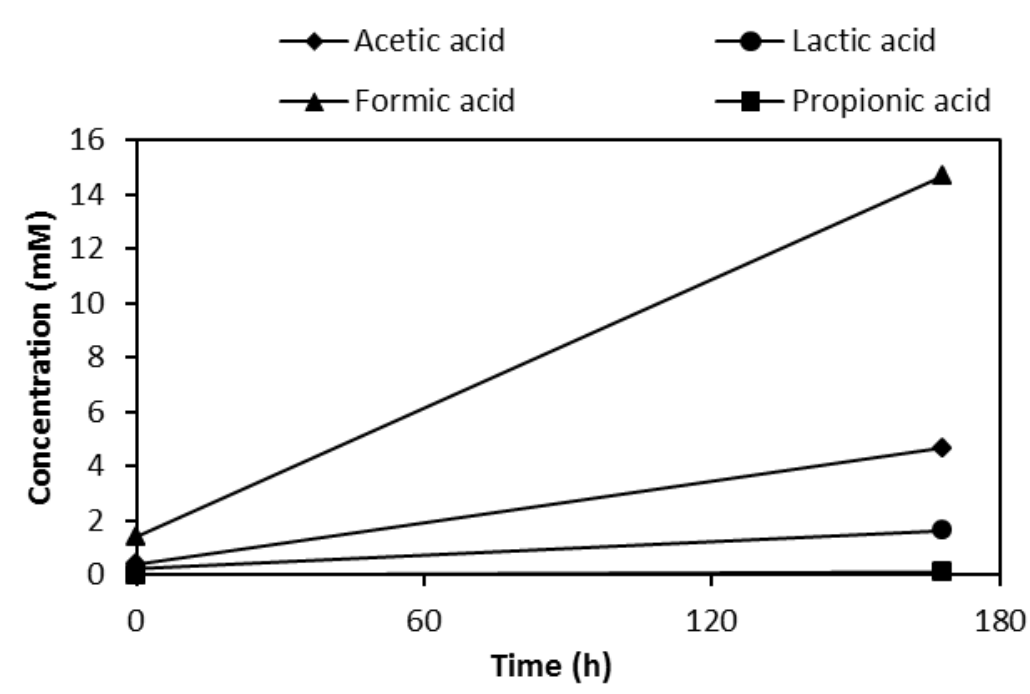

Figure H31 Concentrations of organic acids in photofermentation of $R$. capsulatus YO3 (Hup-) on molasses medium with $5 \mathrm{mM}$ sucrose hydrogen production media.

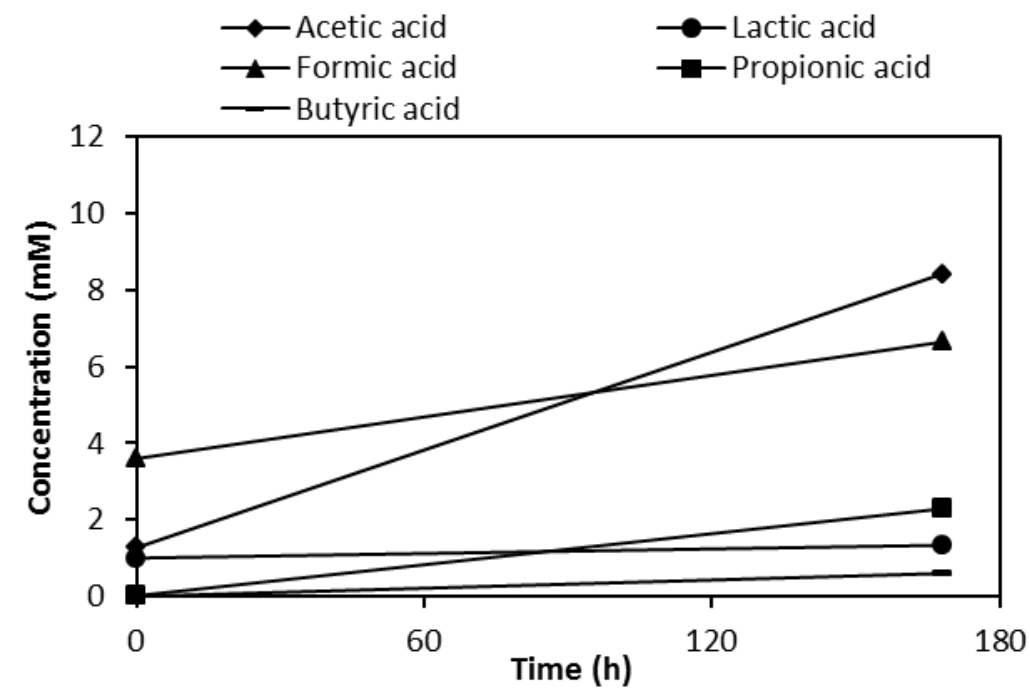

Figure H32 Concentrations of organic acids in photofermentation of the cocultivation of $R$. capsulatus YO3 (Hup-) and $R$. sphaeroides on molasses medium with $5 \mathrm{mM}$ sucrose hydrogen production media. 


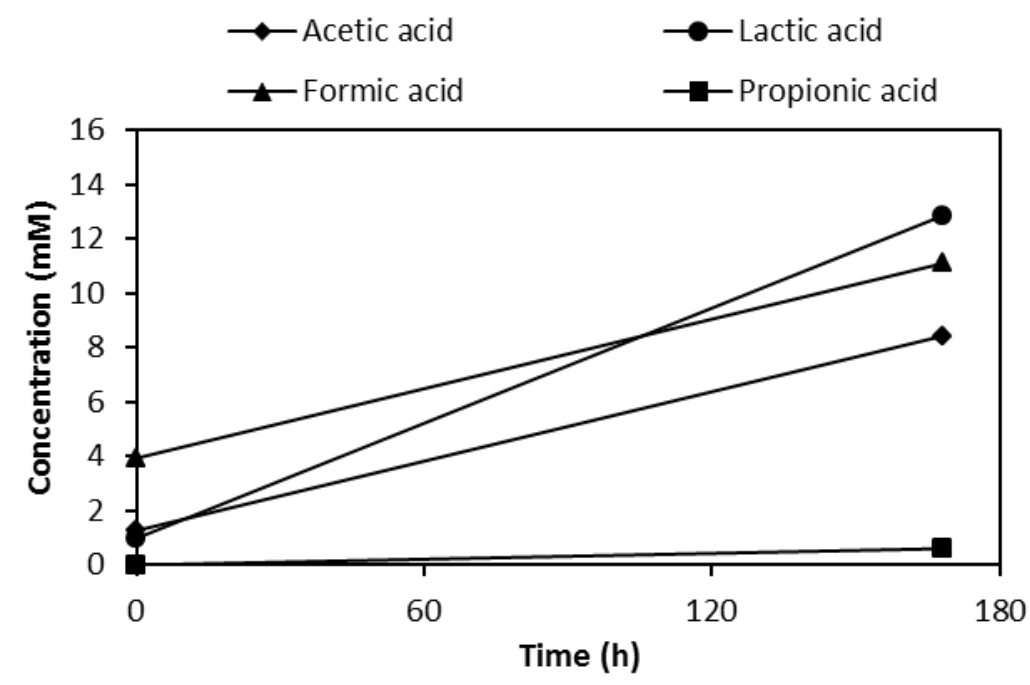

Figure H33 Concentrations of organic acids in photofermentation of the cocultivation of $R$. palustris (DSM 127), $R$. capsulatus YO3 (Hup-) and $R$. sphaeroides on molasses medium with $5 \mathrm{mM}$ sucrose hydrogen production media. 


\section{APPENDIX I}

\section{I1 Calculation of substrate conversion efficiency (\%)}

For calculation of $R$. capsulatus YO3 on $5 \mathrm{mM}$ molasses medium.

Substrate conversion efficiency $(\%)=\left(\right.$ Theoretical mole of $\mathrm{H}_{2}$ over consumed substrate) / (Experimental mole $\left.\mathrm{H}_{2}\right)$ x 100

Volume of reactor $=50 \mathrm{ml}=0.051$

Theoretical mole of hydrogen on sucrose $=24$

$\mathrm{C}_{\mathrm{f}}=$ Final concentration of sucrose $(\mathrm{mM})=5.1$

$\mathrm{C}_{\mathrm{o}}=$ Initial concentration of sucrose $(\mathrm{mM})=2.7$

Theoretical $\mathrm{H}_{2}=\left(\mathrm{C}_{\mathrm{f}}-\mathrm{C}_{\mathrm{o}}\right) \times$ Volume of reactor (l)

$$
=(5.1-2.7) \times(0.05)=0.12 \text { moles } \times 24=2.88 \text { moles } \mathrm{H}_{2}
$$

Experimental Produced $\mathrm{H}_{2}=35.64 \mathrm{ml} / 22.4 \times 10^{-3}=1.59 \mathrm{mmol}$

Substrate conversion efficiency $(\%)=(1.59) /(2.88) \times 100=55.2 \%$

\section{I2 Calculation of hydrogen productivity}

The formula for calculation of hydrogen productivity is given as an example for calculation of $R$. capsulatus YO3 on $5 \mathrm{mM}$ molasses medium.

$\mathrm{t}=$ Duration of hydrogen production (hour) $=72$

$\mathrm{v}=$ Volume of culture $=0.051$

$\mathrm{V}_{\mathrm{H} 2}=$ Produced hydrogen $=33.66 \mathrm{ml}$

Hydrogen productivity $\left(\mathrm{mmol} \mathrm{H}_{2} / \mathrm{l}_{\mathrm{c}} \cdot \mathrm{h}\right)=[33.66 \mathrm{ml} / 22.41] /[0.05 \times 72]=0.41$ 


\section{I3 Calculation of light conversion efficiency (\%)}

Using the data of $\mathrm{R}$. sphaeroides on $5 \mathrm{mM}$ sucrose medium.

$\mathrm{V}_{\mathrm{H} 2}=0.861$

$\mathrm{I}=114.286 \mathrm{Watt} / \mathrm{m}^{2}$

$\mathrm{d}_{\mathrm{H} 2}=0.089 \mathrm{~g} / \mathrm{l}$

$\mathrm{A}=0.002 \mathrm{~m}^{2}$

$\mathrm{t}=$ Duration of $\mathrm{H}_{2}$ production

$$
\eta(\%)=\frac{33.6 \times \rho_{\mathrm{H}_{2}} \times \mathrm{V}_{\mathrm{H}_{2}}}{\mathrm{I} \times \mathrm{A} \times \mathrm{t}} \times 100
$$

light conversion efficiency $(\%)=(33.6 \times 0.089 \times 0.86) /(114.286 \times 0.002 \times 180) \times 100$

$$
=6.25 \%
$$

